\title{
Un/Settlement:
}

\section{Counter-Memories of Migration and Railways in Southern Mexico}

\section{By}

\section{Victoria Simmons}

A thesis submitted to the Faculty of Graduate and Postdoctoral Affairs in partial fulfillment of the requirements for the degree of

\section{Doctor of Philosophy}

in

Sociology

\author{
Carleton University \\ Ottawa, Ontario \\ (C) 2018 \\ Victoria Simmons
}




\begin{abstract}
The Ferrocarril Panamericano (Panamerican Railway) has long served as a space of livelihood, exchange and integration for the communities of the Pacific Coast of southern Mexico. Nevertheless, in recent decades, the historic vitality of this railway, its passengers and communities has been buried under narratives of migrant criminality, terror, and victimhood. As a means of lightening the contemporary weight of security imaginations, this dissertation draws on archival and interview data from diverse locations in Mexico to offer a series of countermemories of migration on the Ferrocarril Panamericano in southern Mexico. Each countermemory aims to foreground memories that have been buried and to reconnect historical knowledges that have been separated from one another. It reconnects studies of migration and governance with histories of settlement, transport and state-making. It also highlights the expulsions and dispossessions of today in connection with the transit migration phenomena.
\end{abstract}

\title{
Sinopsis
}

Desde su inauguración, el Ferrocarril Panamericano ha servido como espacio de sustento, intercambio e integración para las comunidades de la costa del Pacifico al sur de México. Sin embargo, en años recientes, la vitalidad histórica de este ferrocarril y de sus pasajeros se ha enterrado bajo las narrativas e imágenes de criminalidad, terror y victimización de migrantes. Como manera de aligerar el peso de este imaginario securitizado, esta tesis ofrece una serie de contra-memorias de los ferrocarriles y las migraciones en el sur de México. 


\section{Prologue \& Acknowledgements}

To all the participants who I interviewed for this study, thank you for your time, courage and trust. Archival research for this project would not have been possible without the support of the Centro de Documentación e Investigación Ferroviarias (CEDIF) at Mexico’s National Railway Museum in Puebla. I am particularly indebted to Isabel Bonilla, Jefa del Departamento de Biblioteca Especializada, for patiently and passionately sharing with me her vast knowledge of Mexican railway history. In Mexico City, I am grateful to Linda Arnold for generously sharing her time and expertise to help me navigate the Archivo General de la Nación (AGN). I also wish to thank Tracey Goode for her research assistance in diverse archives in Mexico, and Sara Torres for her friendship and for always welcoming me into her home.

This dissertation was made possible thanks to generous financial contributions from many institutions and private donors. From 2011 to 2016, the Faculty of Graduate and Postdoctoral Affairs (FGPA), and the Department of Sociology and Anthropology at Carleton University provided regular contributions to this project via scholarships, travel funds, teaching and research assistantships. This project also benefitted from a two-year Social Sciences and Humanities Research Council (SSHRC) doctoral award (2014-2016); a one-year Ontario Graduate Scholarship (2013-14), and; a six-month grant from the Borders in Globalization (B.I.G) project (2016). Finally, I wish to thank the Province of Quebec for choosing to make affordable childcare a policy priority which enables women to contribute to science without giving up a family-life.

The field work and writing of this dissertation was made possible with the financial support from the many private donors who have contributed to Carleton University's internal awards. I am particularly grateful for the TD Graduate Travel Award in Migration and Diaspora 
Studies, which supported my field research in Mexico in 2014; the Graduate Research and Innovative Thinking Award (GRIT), which supported the archival portion of my field research in Mexico in 2015; the Norman Pollock Memorial Award for Latin American Studies and the Hamlin Graduate Bursary, which supported the writing of the dissertation in 2016. The Graduate Students Association at Carleton University also supported this project at various points by contributing funds for field research in Mexico, the writing and defence of this dissertation in 2016-18. Finally, I am grateful to Pablo Policzer and Monique Greenwood for offering me space, resources and academic comradery during the final stages of dissertation writing at the Latin American Research Centre (LARC) at the University of Calgary.

To my mentors: To William Walters, my dissertation supervisor, thank you for your guidance, support, professionalism and overall openness and flexibility during the research and writing processes. Working with you has been an absolute privilege, and I am so very grateful for your mentorship. Laura Macdonald wrote numerous letters of support for diverse applications and offered me opportunities to build my professional networks and share my research with others. I am grateful to Sonya Lipsett-Rivera for sharing her expertise and contacts in support of my archival research in Mexico. Tanya Basok also played a pivotal role in the earlier stages of this project's development. She wrote letters of support, offered feedback as a member of the examining committee on my comprehensive exams and project defense. I am grateful to Bruce Curtis, Daiva Stasiulus, and Martha Rojas-Wiesner for their support with the early development of this dissertation project.

Over the course of my doctoral studies, I regularly attended reading groups which provided me with the opportunity to cultivate ideas and receive feedback on diverse aspects of this dissertation. I am grateful to all participants in these groups, and I wish to highlight the many 
important contributions from Jiyoung Lee An, Kevin Partridge, and Christine Pich. To the many colleagues, faculty, and staff at Carleton University who also supported this work: Xiaobei Chen, Augustine Park, Martin Geiger, Paula Whissel, Marlene Brancato, Darlene Moss, and my colleagues from the 2011 cohort of the $\mathrm{PhD}$ program in Sociology. Finally, I also wish to extend a special thanks to my friend, Jennie Nichols, who is an example to follow on so many levels.

To my mother, Frances Simmons: Thank you for your unwavering support through every stage of this journey. She has offered every type of support imaginable. Her contributions have been invaluable, and the completion of this project would not have been possible without her. To my children, Evan and Leo, thank you for gifting me daily reminders to play, laugh and snuggle, regardless of the number of projects and deadlines that I may have on the go at any given time. Your tiny toes and big smiles are my inspiration. 


\section{Table of Contents}

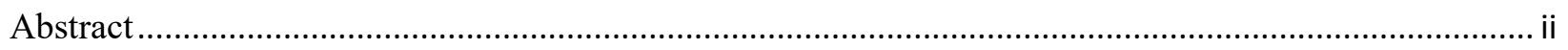

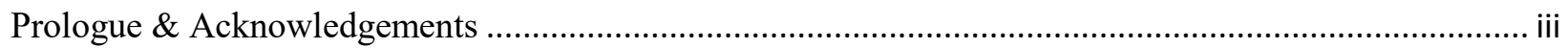

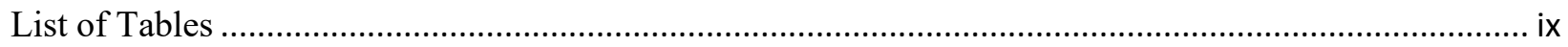

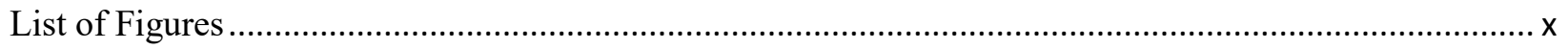

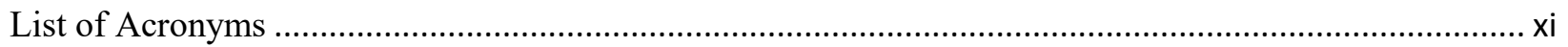

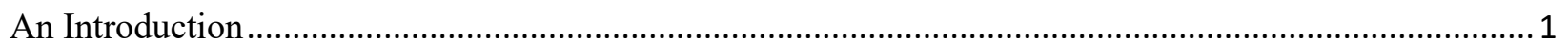

The Global Migration Crisis: What We Know …....................................................................... 2

Security Frameworks: What They Don't Tell Us ..................................................................... 10

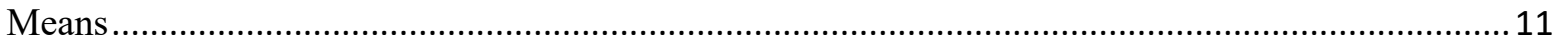

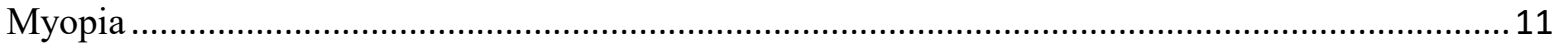

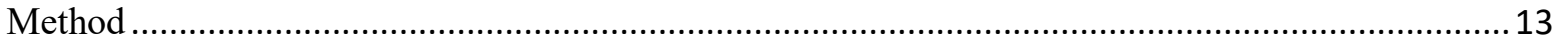

Research Questions, Aims and Approaches .............................................................................. 15

Drawing our Gaze to the Middle: An Infrastructural Account of Migration ...................................17

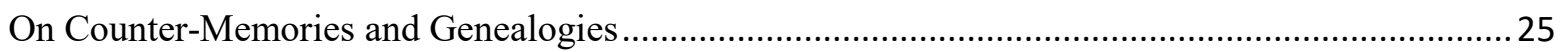

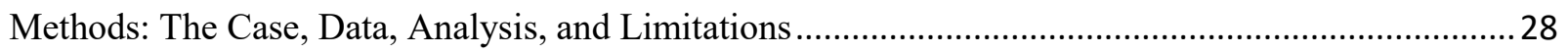

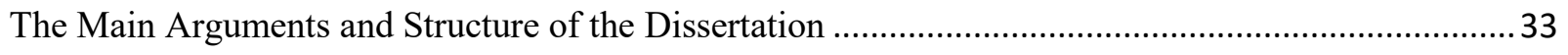

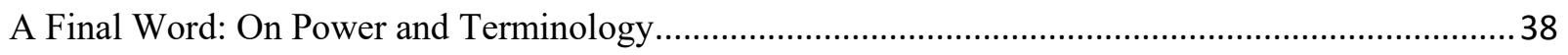

Chapter 1- Building a Railway and a Modern State …..........................................................................40

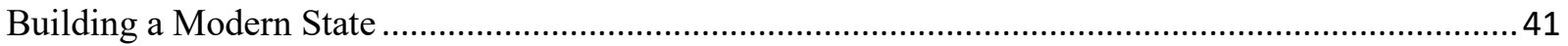

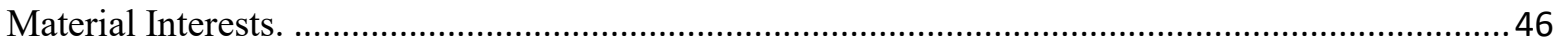

Panamericanism and the Expansion of Frontier Economies......................................................50

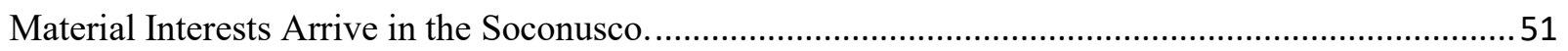

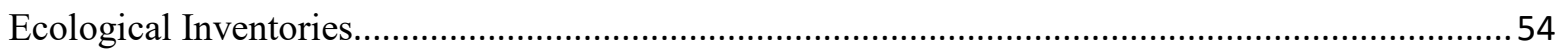

Settlement and Labour: Interdependent Migrations ................................................................ 58

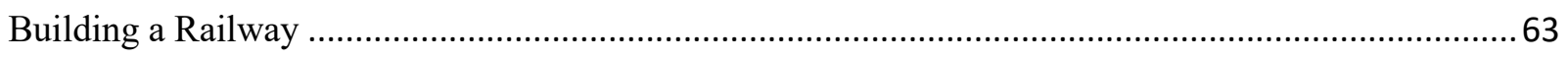

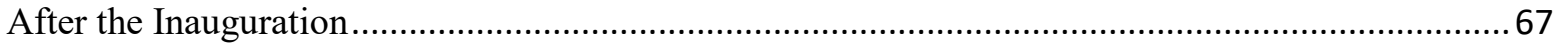

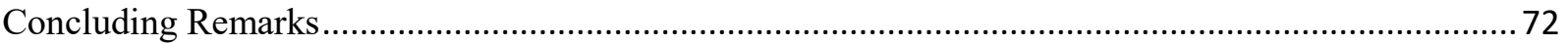

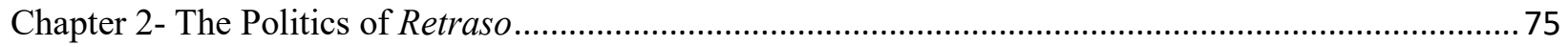

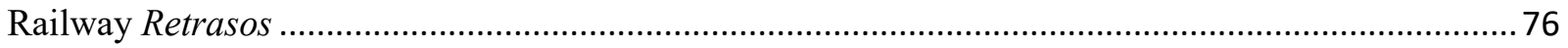

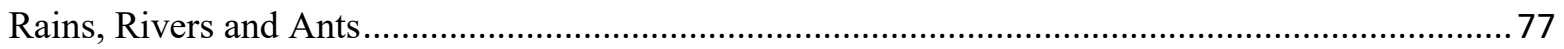

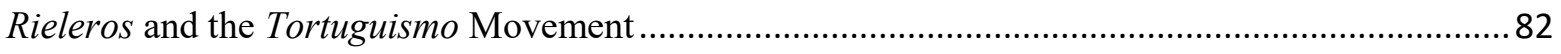


Road-Building, Cultural Inventories, and Tourist Mobilities ........................................................ 87

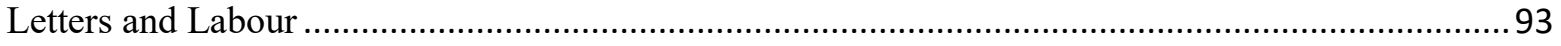

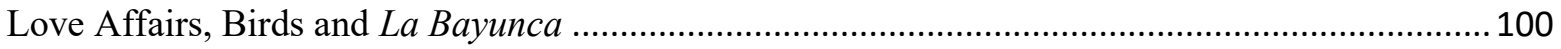

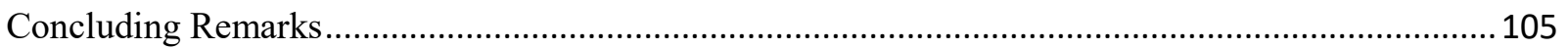

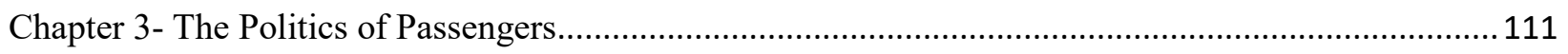

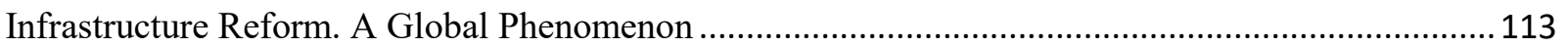

Unbundling the Railways: The Question of Vertical Separation................................................. 115

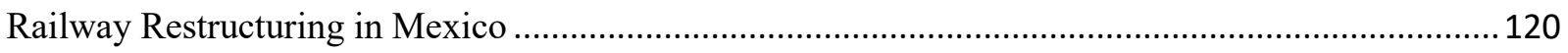

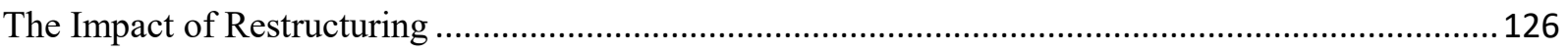

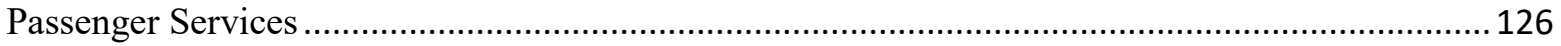

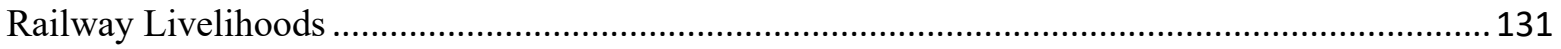

Concluding Remarks - On Jurisdiction and Accountability .......................................................... 132

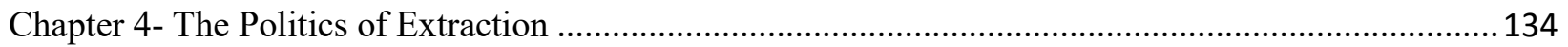

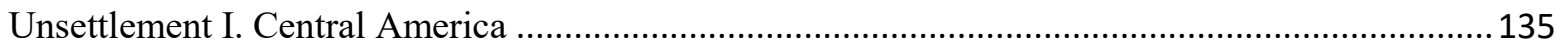

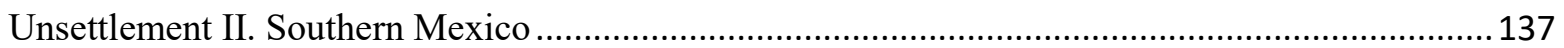

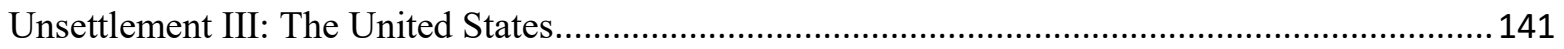

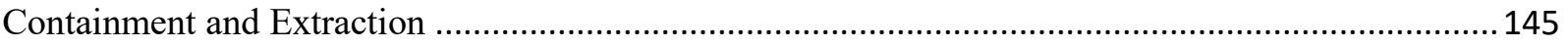

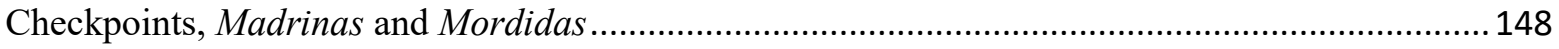

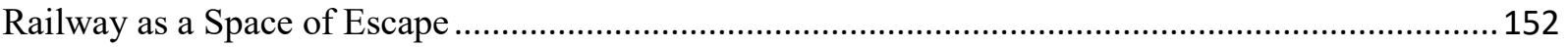

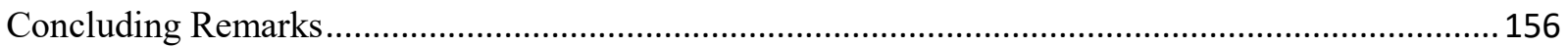

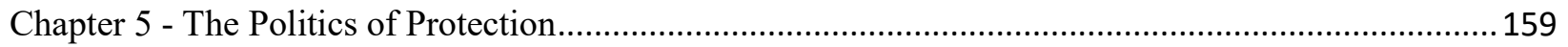

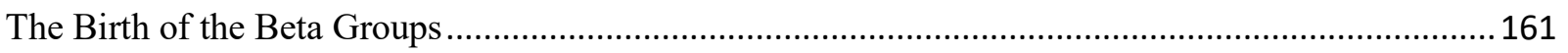

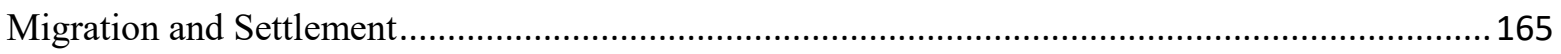

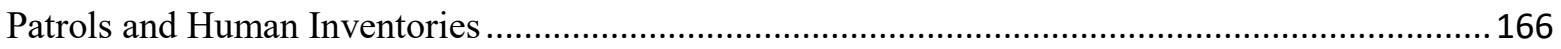

Policing the Police and Other Governmental Dilemmas .......................................................... 172

Post data. From Policing Patrols to Search and Rescue Brigades.................................................. 176

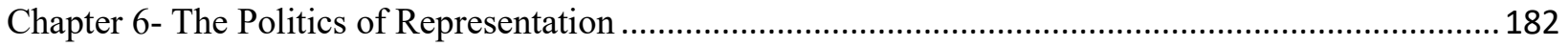

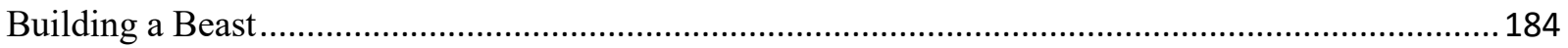

Feeding the Beast: Capturing Stories, Images and Spaces ...................................................... 188

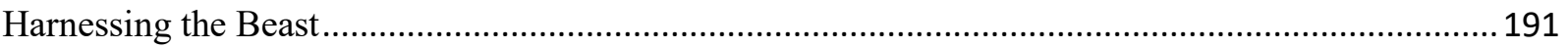

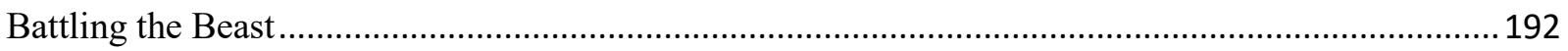

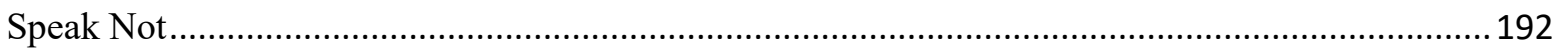

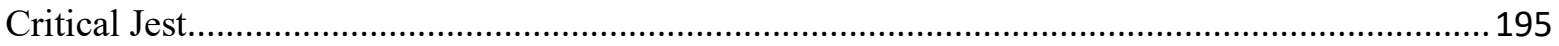




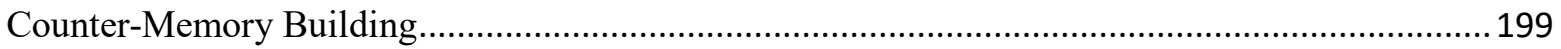

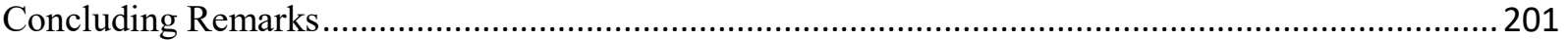

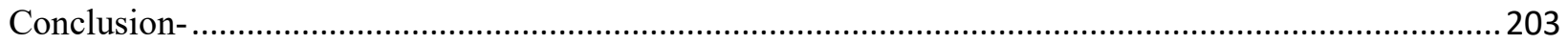

On the Politics of Mobility and (the New Frontier of) State-Making .................................................... 203

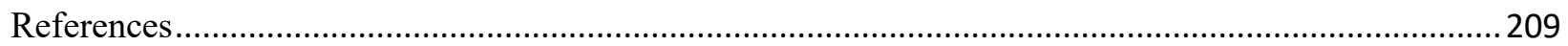

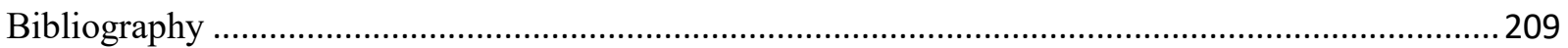

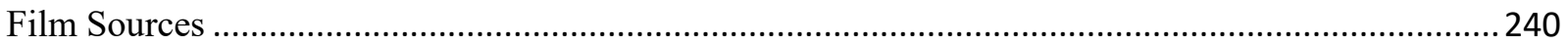

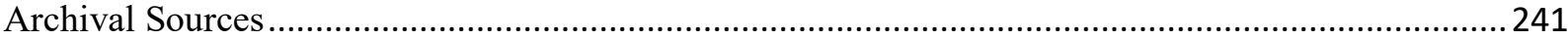

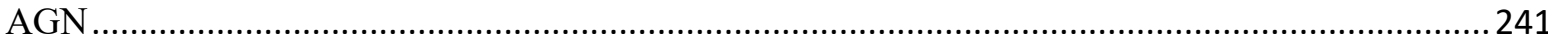

Appendix A: Key Historical Dates for El Ferrocarril Panamericano ..................................................2242

Appendix B: Map of Settlements and Stations along the Panamericano ..............................................243

Appendix C: Map of Railways in Southern Mexico (1950) ............................................................245 


\section{List of Tables}

Table 1- Transfer of railway lines to private concessionaries............................................................123

Table 2- Total Volume of Inter-Urban Railway Passengers in México 1988-2005 …..........................126

Table 3- Passenger Services Available in Southern Mexico in 1991 ..................................................... 127

Table 4- Total Number of Removals from the United States 1988-2005 ............................................. 143

Table 5- Evolution of Migrant Detentions \& Deportations from Mexico 1988- 2005 ............................ 147 


\section{List of Figures}

Figure 1"A Ramshackle Freight Train Known as La Bestia (The Beast)" ............................................... 1

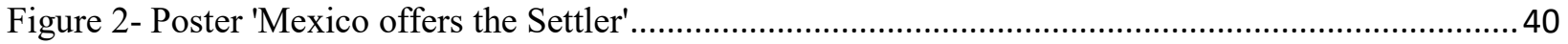

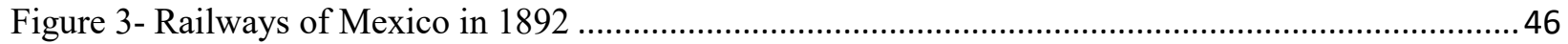

Figure 4 Map of the Soconusco (Chiapas).................................................................................... 54

Figure 5 Monument Commemorating Soconusco's First Japanese Settlement 'Enomoto' ........................59

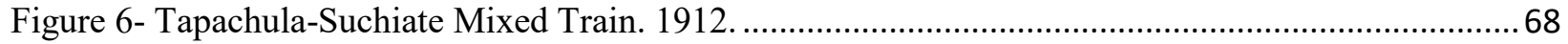

Figure 7- Map of the Panamericano and Rivers in 1912 ................................................................... 70

Figure 8- The Old Cart and The Central American Train (La Vieja Carreta y El Centroamericano) ....... 75

Figure 9- System of Panamerican Highways in Mexico and Central America (1955) ............................92

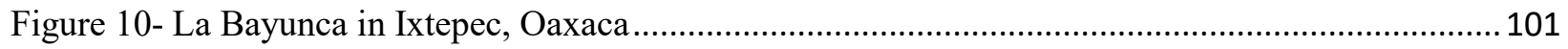

Figure 11- La Bayunca in the Ixtepec Train Station ........................................................................104

Figure 12- The Central American Arrives in Tapachula on Inaugural Journey (1955) ......................... 106

Figure 13- Map of Route of Central American Train (Direct Service Between Veracruz -Tapachula) ...107

Figure 14- 'Modern Tradition' Announces the Inauguration of the Centroamericano ............................ 109

Figure 15- Las Bayunqueras in Ixtepec, Oaxaca ............................................................................. 111

Figure 16- Poster in Embassy Building in Tapachula: 'Migrant Friend: Your Child has the Right to a

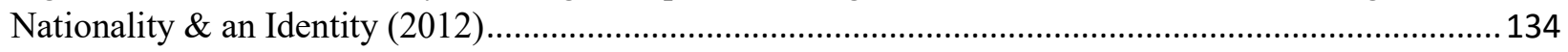

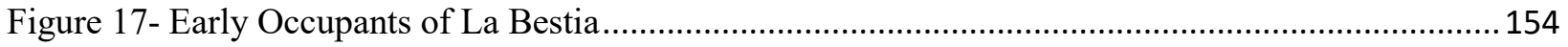

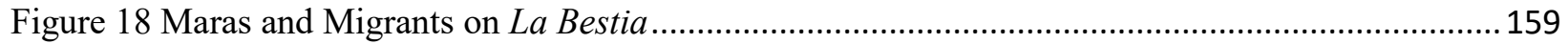

Figure 19- Map of the Beta Groups' Operations in 2005 .................................................................164

Figure 20- Posters and pamphlets used for orientation of 'Migrantes' and 'Indocumentados' during the

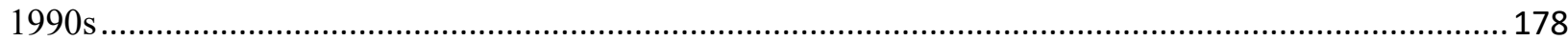

Figure 21 -Posters and pamphlets used for orientation of Migrantes following the 2001 reform ............179

Figure 22- Carters with Beasts of Burden en Route to Arriaga. .......................................................... 183

Figure 23- A Railway Bridge in Chiapas is Destroyed Following Hurricane Stan (2005).................... 189

Figure 24 Route of 'the Beast' Train Expands to the Gulf Coast ..........................................................190

Figure 25 "If You are Migrants, Then Show It! The World Needs to See your Suffering!"....................196

Figure 26 -Journalists Hunt Migrants to Capture their Stories ............................................................ 197

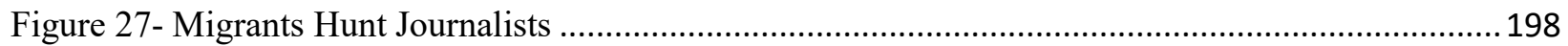

Figure 28 -El Tren Peregrino (The Pilgrim's Train) .......................................................................... 199

Figure 29- Awaiting the Arrival of a Train at Tapachula Station on the Panamericano......................... 203 
List of Acronyms

AGN- Archivo General de la Nación

(National Archive of Mexico)

CEDIF- Centro de Documentación e Investigación Ferroviarias

(Railway Documentation and Research Centre)

FNM- Ferrocarriles Nacionales de México (National Railways of Mexico)

INM- Instituto Nacional de Migración (National Migration Institute)

PGR- Procuraduría General de la República (General Office of the Republic)

SCOP- Secretaría de Comunicaciones y Obras Públicas

(Secretary of Communications \& Public Works)

SCT- Secretaría de Comunicaciones y Transportes

(Secretary of Transport \& Communications) 


\section{An Introduction}

"The evening news in Mexico regularly features footage of a ramshackle freight train known as La Bestia (The Beast) making its way across the country bearing a cargo of illegal immigrants trying to reach the United States' southern border. One can see hundreds of men, women and children perched on the roof, crammed between the boxcars, clinging to the sides. The trains are loaded with cement, iron, quartz, wheat, corn, diesel, vegetable oil, fertilizer, or wood, but the human cattle along for the ride have no food, drink or guarantee of safety... Everyone knows the road to the American dream runs through the Mexican nightmare and that many passengers on "the train of death" will either perish during the journey, disappear by the wayside or be wounded, robbed or mutilated...Hondurans, Salvadorans and Guatemalans escape from hell, journeying through the limbo of Mexico to be held in the purgatory of shelters at the U.S. border, always striving towards the paradise of rejoining family members in the promised land. Is it morally acceptable — or even legal — to send thousands of children back to hell?

Mr. Obama, while you ride in the comfort and safety of The Beast (as the Secret Service calls the armored presidential limousine), give some thought to the hopeful passengers on the Bestia."

\section{Homero Aridjis ${ }^{1}$,}

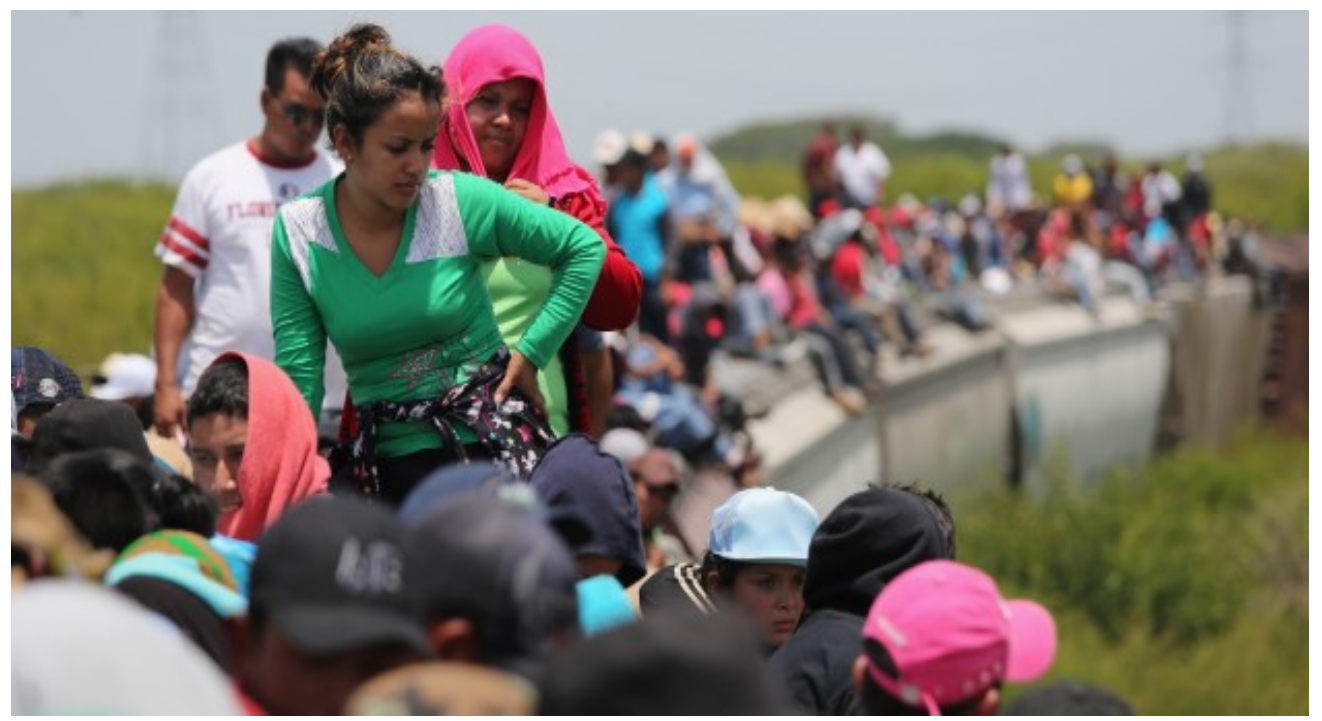

Figure 1“A Ramshackle Freight Train Known as La Bestia (The Beast)”

Source: Moore, John. N.d. Getty Images. Retrieved June 29, 2018

(https://www.huffingtonpost.com/homero-aridjis/migrants-train-of-death-americab_5568288.html).

${ }^{1}$ Aridjis, Homero. 2014. Migrants Ride a 'Train of Death' to Get to America \& We're Ignoring the Root of the Problem. Huffington Post. July 8, 2014. Image by John Moore via Getty Images Accessed online June 29, 2018. https://www.huffingtonpost.com/homero-aridjis/migrants-trainof-death-america-_b_5568288.html 
In the mid-1990s, migrants began riding atop the railway cars of freight trains as part of their journeys through Mexico to the United States. Since then, many of these migrants have been injured, amputated or killed in train accidents and violent encounters with street gangs, drug cartels and state officials who patrol the railways. Many migrants have also received shelter, food, clothing, and spiritual support from a diversity of local and international humanitarian actors, who, for many years, have also patrolled the railways. The media has documented this phenomenon extensively, making this 'ramshackle freight train known as La Bestia (The Beast)" (Aridjis 2014) a window through which to see into the global migration crisis in the Americas.

Hyper-visible, dangerous migrant journeys like those of La Bestia are front and centre in the politics of migration today. Sadly, after more than twenty years of images and stories of harrowing migration journeys not much has changed. News headlines still regularly announce watery tragedies in the Mediterranean, and the loss of lives on railways and other transit routes around the world. It is most horrifying to realize that migrant deaths such as these have become the new normal. This dissertation asks why. How can we explain the rise of highly- visible and dangerous migration journeys in the world at the turn of the twenty-first century?

\section{The Global Migration Crisis: What We Know}

Migration studies is a collective effort to understand patterns and processes involved in international migration (see, for instance, Zolberg 1989; Castles and Miller 1993; Massey et al. 1993). Emerging in the context of widespread industrialization and urbanization of the late 19th and early 20th centuries, the earliest studies in the discipline largely focused on the demographic and economic determinants of migration. Migration was predominantly understood to be the product of populations responding to labour market pressures by moving from rural areas of high labour supply and low wages to industrial and urban centers where labour demand and wages 
were higher (Ravenstein 1885). Subsequently, for much of the twentieth century, scholars built upon these pioneer studies, producing a more nuanced understanding of the structural forces which 'push and pull' migrant populations in and out of the labour markets of countries of origin and destination (Massey 2015).

Nevertheless, toward the end of the twentieth century, scholars began to note that, while economic and demographic factors may 'push and pull' migrants in one direction or another, states and borders increasingly had the final word about whether or not these migrations actually came to fruition (Zolberg 1989). A series of calls were made to account for the role of the state in mediating international migration, and, as a result, many scholars began to examine how and why states shape the patterns and character of migrations through their political interventions (Zolberg 1989; Massey 2015).

While widespread industrialization and urbanization informed early theorizations of migration, the political turn in migration theory emerged during a large-scale, societal transformation known widely in the social sciences as globalization. During the 1990s, global mobilities increased in volume and speed, as points of connectivity exploded globally. The end of the Cold War, the liberalization of trade, and technological advances in communications and transport technology all challenged extant barriers to mobility while simultaneously multiplying infrastructural capacities to facilitate the global movement of people, commodities and ideas. During this period, scholars and politicians alike pondered the implications of these changes. The revolution in transport and communications technology might have suggested that it was high time to consider how infrastructure shapes migrations. Nevertheless, scholars took migration theory down a political path, which instead examined the shifting relationship between migrants and the state. 
One topic of popular debate concerned the future of the modern state: Would these changes bring about the demise of the nation-state and the rise of a world polity? Within this context, in 1990, Strategic Survey published its annual review in which it declared that the world was living "an era in which fundamental political and economic changes in the international system result in large-scale movements of people which affect political, economic and strategic developments worldwide" (1990: 37-38). Gone were the days when policy-makers would refer to migrants and refugees in terms of labour. Now, they argued, population movements were foreign policy and national security issues because: 1.) Population movements were often caused by foreign policies, such as military or political interventions; 2.) They had serious consequences for international relations; and, 3.) Migrations, particularly refugee flows, could be used as foreign policy tools (1990:38). In other words, migrants were now thought to be a key problem and mechanism for international relations and diplomacy. They were now considered to be a question of 'high politics' (Castles and Miller 2009).

Two years later, in 1992, Myron Weiner expands upon this notion of international migration as the cause and effect of inter-state conflicts. Like the Strategic Survey, he asked how and why states' actions force or induce international emigration, but, rather than focus solely on migration's effects on international diplomacy, he asked about its consequences for the internal stability of the state as well. In particular, he was concerned about explaining the inter- and the intra-state conflicts which could arise as a result of international migration flows, when states might regard migrations as a threat, and how states might react to this perceived threat. In what is now considered a pioneering publication, he argued that international migration had grown:

...propelled by economic differentials, internal political disorder, and global networks of communication and transportation; the political as well as economic constraints on the 
admission of migrants and refugees; and the truly global character of migration- suggest the need for a security/stability framework for the study of international migration that focuses on state policies toward emigration and immigration as shaped by concerns over internal stability and international security. Such a framework should consider political changes within states as a major determinant of international population flows, and migration, including refugee flows, both as cause and as consequence of international conflict (1992: 94-95).

The security and stability framework, Weiner argued, was to complement - not replace the dominant focus on the economic causes and effects of international migration, which, in his opinion, suffered from two great deficiencies. First, it neglected the central role of governments and political forces in forcing, promoting or preventing population movements in ways that were unrelated to economics. Secondly, it did not account for the non-economic factors that governments refer to when making decisions about who gets to leave or enter a country, nor governments' capacity to control such flows. In short, Weiner wished to incorporate the political determinants of international migration into the existing discussion, which until then had been based largely on demographics and economics.

Following the publication of this article, Weiner utilized the security/stability model as the basis for his edited book entitled International Migration and Security (1993), and later expanded upon it for his full-length monologue The Global Migration Crisis: Challenge to States and Human Rights (1995). Together these publications offered a basic research agenda which essentially argued in favor of the securitization of migration ${ }^{2}$. They contended that

\footnotetext{
${ }^{2}$ I use this term to mean the process by which the demographic/economic analysis of migration was replaced by a political analysis of migration which was dominated by a security framework.
} 
migration was now more than ever a security issue because of real, objective changes in the material world, often referred to as 'globalization'. Security, according to Weiner, is the absence of real or perceived existential threats to the nation-state and its population. Whether or not these threats were real was largely thought to be irrelevant, since, as Weiner argued “...many governments and their citizens do believe that there is a crisis- although they do not always agree what the crisis is" (Weiner 1995:8).

The basic research agenda proposed in Weiner's works comprised a variety of scientific puzzles relating to migration as a state-security problem. These puzzles were grouped into five, thematic 'dimensions': 1.) Control over Entry (fear of loss of control and state sovereignty); 2.) Absorption (migrants' labour market and socio-cultural integration); 3.) International Relations and internal stability (political conflicts between and within countries sending and receiving countries); 4.) International Regimes and Institutions (powers to intervene), and 5.) Moral considerations (not everyone who wants to come can, so how do we select?) (Weiner 1995). Thus, for the remainder of the 1990s, many scholars focused on explaining the origins, patterns and effects of the 'migration crisis' on the security of states and their populations, how states could and did decide to respond to this multi-dimensional threat, and the limitations and (in) effectiveness of these state policy prescriptions for maximizing state security.

Control over entry puzzles, for example, consisted in determining whether and to what degree globalization challenged states' ability to effectively exercise sovereignty vis-à-vis migration policy and practices and how any real or perceived loss of control might affect state security (Cornelius et al 1994; Joppke 1998). With regards to migration as a threat to collective, cultural values and socio-economic institutions (absorption), scholars asked questions such as how migrant-receiving societies came to regard international migration as a cultural threat 
(Cornelius et al 1994; Castles and Miller 1993; Davies 2000) and what state policies assimilation, deportation, intervention were available and most effective for dealing with conflict arising from social tensions between native and immigrant populations (Weiner 1995).

Concerning migration as a threat to international relations and internal stability, scholars examined how international migrants could be a source of 'politically subversive or divisive' populations for host countries or a source of external funding - via the remittances of diasporas for political subversion in countries of origin (Davies 2000); how diasporas become a source of inter-state conflict between home and host countries (Sheffer 1993; Weiner 1993); and how states utilize migration policy to respond to perceived internal and external threats to their security (Weiner 1995).

Weiner's migration and security research agenda did not move forth without criticism. Debates emerged on a number of fronts, including: 1.) Who or what should be secured; 2.) How security should be defined, and, 3.) The nature of the migration-security nexus. Human security scholars, for instance, agreed that migration and security were a problem connected to the processes of globalization. Nevertheless, they were critical of the move to prioritize state security over the human security of individuals. They argued that this assumed that all states are willing or capable of guaranteeing security for all of the individuals and social groups which reside within their territories, which, in an era of globalization, was problematic since states' powers to guarantee security for all were increasingly compromised (Poku, Renwick and Glenn 1998; Basch 2004). Human security meant procuring people's freedom from fear, that is, "protection from sudden and hurtful disruptions in the patterns of daily life-whether in homes, in jobs or in communities," as well as their freedom from want, meaning chronic threats to people's safety due to hunger, disease and repression (UNDP 1994: 22). Seven categories or types of threats to 
human security were outlined, including economic security, food security, health security, ecological security, personal security, community security, and political security (UNDP 1994).

Human security scholars also critiqued existing understandings of 'migration' and 'security' as universal, absolute, static and timeless categories. These were similarly problematic, they contended, since what might constitute security for one individual, social group, region or state is often the cause or source of insecurity for another (Armijo 2011). Thus, the human security approach underlined migration and security's relative, fluid and interdependent nature (Poku, Renwick and Glenn 2000; Marchand 2008; GTD 2008, UNDP 1994), and, it is because of this view that it was commonplace for human security scholars to critique state security policies and practices as the very sources of the insecurities facing migrants and their communities of origin, transit and destination (see Marchand 2008 and Castillo 2005, for instance). In short, the human security perspective proposed another vision of the migration-security nexus which moved away from a state-centric perspective and toward a human-centric (including migrant) lens on the problematic of migration and security:

...by placing the poor, the disadvantaged, the voiceless, the unrepresented, and the powerless at the core of their research agenda, [and] recogniz[ing] that for the majority of the people in the world, apparent 'marginal' or 'esoteric' concerns, such as ecological security, food, and economic security- are far more real and immediate threats to their security than interstate wars. This broader conception of security focuses variously, or indeed interchangeably, on the individual, on society, on civil society, on community, on the continuing integrity of ethnic or cultural groups, and on global society (Poku and Graham 1998: 11). 
Finally, it is worth noting that not all migration scholars agreed that globalization had indeed produced a migration and security crisis. Zolberg (2001), for instance, expressed concerns over the reframing of migration as a security problem, arguing that: "The prevailing sense of an 'international migration crisis' has profoundly inflected the consideration of policy alternatives. In particular, it has been invoked to justify draconian measures to protect national borders, even at the expense of other considerations, notably humanitarian obligations towards refugees and generous policies of family reunion" (Zolberg 2001: 1).

Many scholars agreed that "the 'crisis' specter must be exorcised" (Zolberg 2001: 1) and a more measured approach to the migration and security question was required. To exorcise the crisis specter, many critical scholars focused their attention on deconstructing the increasingly common-sense association between migration and (threat to) security. Kritz (2001), for instance, presented statistical evidence to challenge the notion that globalization had brought about realworld transformations, such as high population growth in 'less developed' countries, which threatened to spillover into 'more developed' receiving countries, such as the United States.

The Copenhagen School sought to deconstruct the migration-security nexus by presenting evidence that security and security threats were constituted discursively through an intersubjective and discursive process called 'speech acts.' 'Securitizing actors' (politicians, states, police, media and other people with power), they argued, engage in 'speech acts' which draw attention to someone or something-like migration- which, according to their discourse, represents an existential threat to a particular collectivity (also referred to as the 'referent object') and requires extraordinary measures to address. This object referent or collectivity becomes securitized when the audience has accepted the securitizing actors' discourse and its proposed courses of action (Collins 2007; Waever 1998). 
Thus, central to the securitization theorizations, then, is the idea that issues become securitized, not because real life circumstances change and require them to do so, but because it serves the interests or some purpose for the securitizing actors. Huysmans (2000), for instance, utilized this framework to show how the European Union's economic integration involved the development of a common migration policy which centred on security policies and practices that constructed non-EU nationals as a threat to the region's cultural values and social welfare system. This, he argued, facilitated connections between foreigners and terrorism/ crime/ domestic instability and contributed to the constitution of the social and political identity of the European Union as a single community.

\section{Security Frameworks: What They Don't Tell Us}

Because of the political turn in migration studies during the 1990s, the modern state system has come to dominate the spatial imagination of migration studies. States are very often conceptualized as containers of people, and international migrants as people who move from one container to another. With the exception of recent studies of transit migration (see, for instance, Coutin 2005; Duvell 2012; Mainwaring and Brigden 2016; Basok, Belanger, Rojas and Candiz 2015), the movement of people is primarily imagined as a straight line or a circular motion between states of origin and destination. The possibility and terms of people's movement are contingent on migrants' physical location, their juridical relationship to one or more states, and the never-ending political dance between states and migrants. Nevertheless, understanding the politics of migration solely through a state-lens framed by security concerns analyses presents at least three significant challenges to understandings of the politics of migration: Means, Myopia, and Method. 
Means

The state-turn in migration studies lead scholarship to examine how political structures and mechanisms intervene in the economics of migration. It encouraged scholars to think of the diverse ways in which the in/actions of sending states pushed their populations to emigrate. It also encouraged scholars to think of the ways in which receiving states governed immigration. And, in between these two poles, there is a methodological assumption that populations just move from sending to receiving states in an autonomous and unidirectional fashion. Migrations are not autonomous or straightforward, however. Their movement relies significantly on infrastructure. Yet, we know surprisingly little about how networks of knowledge, people, routes and vehicles actually move people, ideas and goods around the world (Xiang and Lindquist 2014; Neilson 2012). ${ }^{3}$ In short, the material and non-material means of movement is ignored or taken for granted in many of the current political theorizations of migration. There are some studies which have begun to shine a light on this assumption and produce knowledge about how movement is produced (see for instance Xiang 2017; Lindquist 2017; Blue 2015). This dissertation will draw on these studies and contribute to the development of knowledge in this area.

Myopia

\footnotetext{
${ }^{3}$ One example is Davis and Eakin (2013) who, for instance, ask why Chiapans took so long to start migrating to the US. Not surprisingly, distance and infrastructure are not at all in the list of factors. Their article repeats push and pull theories of migration, highlighting how there were economic, political, and climatic pushes at the end of the 80s and into the early 1990s, which brought Chiapans into the international labour market.
} 
Migration is predominantly studied as a practice which is isolated from other human mobilities (ie. tourists, pedestrians, commuters etc) and from the movement of goods, symbols, ideas and capital. Furthermore, it is assumed that the state is the only actor with an interest or capacity to regulate migration. Nevertheless, there is ample evidence to suggest that this is not the case. Both Feys (2016) and Blue (2013), for instance, have examined how states and shipping companies actively negotiate their interests, rationales, and techniques for facilitating and policing migration by sea. In his book The Invention of the Passport: Surveillance, Citizenship and the State, Torpey (2000) also offers evidence of the fact that Western European states gained a 'monopoly of the legitimate means of movement' by usurping the regulation of movement from rival claimants, such as churches and private enterprises, during the period between the French Revolution until shortly after World War II. Similarly, Blue (2013) has shown that shipping companies were active in the policing migration during the late 19th and early 20th centuries in relation to settler states of Australia and United States.

Sassen (2000, 1999 and 1988) argues that migrations are not autonomous processes but rather the product of "interaction effects," caused by actors and processes which significantly shape international migrations but are regularly not recognized as part of the equation. From this perspective, migration can thus be understood as the effect of another mobility, such as the movement and settlement of a US agribusiness setting up commercial, export ventures in a region where small-scale landholders were the norm. The effect is the displacement of these landholders, their integration into the wage labour market, often times as migrants (Sassen 2000:67).

Keenan (2002) offers another example of how mobilities interact and shape one another by underscoring the uncertain and variable effects of the movement of images on the movement of 
people. In his case study of the circulation of TV images as weapons in political conflicts of Mogadeshu and Sarajevo, he notes that, although images are often produced with the intention of forming and mobilizing a public, there is no guarantee that a public will form at that particular moment or act in response to the images. Thelle (2015) also argues that the physical movement of people and objects is connected to and, at times, dependent on emotion and knowledge. In other words, the practices of knowing, feeling, and moving are deeply interrelated.

In short, by focusing solely on migration as an isolated system of movement which is governed by states, many studies neglect the fundamental connections and interdependence that migration maintains with other mobilities, such as capital, tourists, deportees, natural resources, goods, symbols and ideas. This makes it difficult to see how the movement of capital brings with it the movement and displacement of people, or how the movement of people and goods are interdependent, as in the case of slave trade between Old and New Worlds was a fundamental necessity of the movement of gold and sugar in the opposite direction. It also makes it difficult to see the panoply of non-state actors, technologies and spaces which have historically mediated, influenced, and interacted with migration through mechanisms, rationales, and goals which are very different from those of the state (see, for instance, Xiang and Lindquist 2014; Cowen 2014 and 2010) It fails to show how mobilities stimulate one another, and how infrastructure plays a pivotal role in shaping these processes. We do not see overlapping and interdependent mobilities phenomena, only crisis moving in a single direction from South to North.

\section{Method}

Drawing solely on the state or the migrants' lens (ie. adopting its concerns, conceptual categories and knowledge practices) raises methodological and ethical issues about the autonomy 
and purpose of scientific research. Accounts of the global migration crisis today - such as the one featured in the epilogue-regularly spotlight a political battle playing out between states and migrants (and their allies). Prevailing wisdom holds that some states actively criminalize and exclude migrants through national security narratives and practices. For many activists and scholars, these narratives and practices subjugate knowledge of the violence which migrants suffer. Based on this logic, myriad actors work tirelessly to showcase testimonies of migrants' insecurity along transit routes around the globe. News reports and research projects often 'chase the migrant' to collect and distribute data on their hidden suffering, or their 'criminal' tactics. Journalists, filmmakers, artists and scholars are out and about trying to see particular 'kinds' of migrants and capture particular stories or voices. They draw attention to the presence of migrants as they move along different routes - Look they are here! Now they are here! They do this! Now they do this! To the minds of many, these stories of harrowing journeys are the fodder needed for battle in the arena of migration politics. They give migrants a voice, or at the very least give them a platform to speak up and defend their character. As a result, migrants are now seen and heard almost endlessly.

However well-intentioned, such research can have real life and death consequences for research subjects and their communities. Nevertheless, these consequences are rarely problematized in the migration studies literature, ${ }^{4}$ particularly in the production and circulation of knowledge on transit migrants. Unfortunately, in this flurry of media production, very little time is given to the question of the ethics of knowledge production and circulation. Voice and

\footnotetext{
${ }^{4}$ Important exceptions can be found Mainwaring and Bridgen's work on Clandestine Migrant Journeys (2016), as well as in Chamayou's (2012) book Manhunt. A Philosophical History, which offers critical insights into the parallels which exist between the present-day practice of 'the hunting of illegals' and historical instances of manhunts for other social groups, such as Slaves, Jews, Black Skins, Indians, and the Poor.
} 
light are assumed to be the remedies -rather than the tools- of migrants' experiences of violence and oppression. The hunt to find and expose migrants' stories is naturally assumed to be on the side of morality.

But what if the search for subjugated knowledges has shone the light in the wrong direction and spoken to the wrong people? What if collecting these migrant stories does not challenge the order of things, but rather reinforces the very power/knowledge regime that uproots, cajoles, and hunts these same migrants? Must uncovering a subjugated knowledge always involve accompanying the so-called powerless populations and giving them voice? What if uncovering the knowledges of the powerful were the more productive format? What if labelling the powerful diasporas as migrants and bringing their migration histories alongside the stories of 'Othered' migrants constituted a genealogical act of insurrection vis à vis knowledge?

What are the ethical responsibilities of researchers and journalists as they map, describe and publish in ever greater detail the array of tactics, spaces and knowledges of migrants and asylum seekers in transit? My concerns regarding this issue constitute one of the reasons why I chose not to interview migrants for this study, and why I concur with Xiang and Lindquist (2014) when they call for a shift in analytical focus away from migrant subjects and toward broader societal transformations, such as the emergence and interaction of the diverse networks which move them.

\section{Research Questions, Aims and Approaches}

The main research question which guides this dissertation is as follows: How can we explain the rise of highly-visible, dangerous migration journeys around the world at the turn of the twenty-first century? Dominant narratives of today will explain this phenomenon as a 
security problem brought forth by the forces of globalization. As we saw in the previous section, there are two main positions which scholars commonly take to explain the phenomenon. One position -the national security stance- suggests that, during the 1990s, globalization introduced real changes to the world, which produced mass migrations and lead sending and receiving states to regard migration as a security threat. The human security position, on the other hand, suggests that the forces of globalization brought about real changes in the world which threaten the security of migrants -not states. Human security scholars will often signal states' expansion of restrictions and controls on migration as one of the factors which cause migrants to embark on these dangerous journeys.

This dissertation distances itself from these security frameworks. Instead, it aligns itself with critical migration scholarship that suggests: 1.) There are inherent dangers in building a relationship between migration and security, and; 2.) Research agendas concerned with migration must critically engage the problem of security by deconstructing those narratives and practices which aim to securitize migration.

With this purpose in mind, I selected La Bestia as a case study, and I began tracing the emergence of highly-visible, dangerous migration journeys on the railways of Mexico. As we saw at the beginning of this chapter, La Bestia, or 'The Beast that Devours Migrants,' is the popular name given to the freight train which Central American migrants ride atop as part of their journeys through Mexico to the United States. ${ }^{5}$ Over the past two decades, La Bestia has become a symbol of danger, lawlessness, and criminality, as well as human hopes, suffering and victimization. It has become a battle ground for the politics of migration and security. La Bestia

\footnotetext{
${ }^{5}$ Though, as I demonstrate in Chapter 6 of this dissertation, La Bestia is itself a mobile and contested symbol which has signified many different items over time: from territory, to a single railway, to any freight train travelling through Mexico with migrants riding precariously atop.
} 
therefore offers an excellent site for deconstructing the global migration crisis and developing alternative perspectives on the rise of highly-visible, dangerous migration journeys.

My research began with two simple questions: Who or what is La Bestia? and How did it come into being? To answer these questions, I utilized genealogy and counter-memories as a means of deconstructing dominant narratives. I also utilized an infrastructural lens to develop an alternate account of the politics of migration and mobility. In the sections that follow, I examine these methodological strategies in greater detail.

\section{Drawing our Gaze to the Middle: An Infrastructural Account of Migration}

"... history is not confined to humanity alone"

(Netz 2004:228)

This dissertation suggests that an infrastructural perspective offers a way to address limitations in our theoretical and methodological approaches to the study of politics of migration. An infrastructural account of migration asks how infrastructure shapes migrations. It asks this question based on the premise that migrations are not autonomous. They do not emerge solely with the beckoning of markets or the cajoling of states. Rather, migrations are made possible where there exist material and non-material means of movement. Infrastructure offers the means of migration. It does so discriminately, however. Not just anyone can migrate and not just anywhere. The unique features of a given infrastructure shape the possibility and character of migrations in specific and constantly changing ways.

What is infrastructure? Infrastructure is commonly regarded as a material network or structure which provides a platform or a means for other processes, movements or interactions to occur. Conjuring images of purely technical and infra-visible systems of pipes, wires, or 
pathways, infrastructure has largely been overlooked and marginalized in studies of society and politics. Nevertheless, in recent years, a growing body of literature has problematized this generalized understanding of infrastructure, thus laying the groundwork for scholars to begin to think through the diverse ways in which infrastructure intersects with migration and mobilities.

In the 1980 s, science and technology studies began to challenge social scientists to pay greater attention and import to the ways in which material and technical objects of seemingly mundane and neutral character can have far-reaching, powerful effects on our social world. Science and technology studies- and actor-network theory, in particular- have challenged the notion that science and technology are divorced from society and politics. Building upon the notions that "science is politics by other means" and that "technology is society made durable" (Latour 1990; Callon, Law and Rip 1986), this line of scholarship suggests that we can only really understand power relations among humans by understanding how they are mediated and stabilized by non-human actants (Latour 1990). This challenge to the science/politics and human/non-human divides in scientific inquiry has opened up scholars to interrogating assumptions about the static, objective, apolitical, and singular character long attributed to infrastructure. As a result, infrastructure has come to be understood as a profoundly political rather than a technical, neutral object or system (Larkin 2013).

We can now see how political aims, rationales and practices are embedded and re/produced in the material design and operations of infrastructure, and how these materialiaties influence the content, character and movement of the mobilities and objects the infrastructure supports. O' Neill (2012), for instance, has offered insights into how liberal values of individual personhood, security, and free circulation have slowly changed the spatial design and governance of a public cemetery in Guatemala. Prior to the 19th century, this cemetery comprised mass 
graves, which were chaotically organized and located in the centre of town. With the expansion of liberal values in the 19th century, and parallel security concerns with miasma, the cemetery was relocated to a hill-top on the periphery of town. Mass graves became individualized and organized in a grid-like fashion with stones and markers. Today, he argues, neoliberal values continue to reconfigure the design and operations of the public cemetery, particularly in response to the problem of overcrowding. Anyone who occupies an individual gravesite without the ability to pay a rent is currently relocated to the unofficial, mass grave which has been fashioned just outside of the cemetery on the property of municipal garbage dump. For O'Neill, this practice connects the realms of life and death through the integration of neo-liberal values of land, personhood and belonging into the burial infrastructure.

Mobility studies and, to a lesser extent, migration studies have begun to look at how routes, transportation infrastructure and vehicles shape the character, possibility and meaning of mobilities and migrations (see for instance, Walters 2015; Adey 2008; Urry 2007). Scholarship has interrogated how the materiality and spatiality of vehicles and routes can shape the subjective experiences and social interactions of their occupants. as well as the practices and representations of mobility and governance.

In his classic work, The Railway Journey, Schivelbusch ([1977] 2014) demonstrated how the introduction of the railway during the 19th century helped to produce new perceptions and modes of social interaction. The materiality of the railway- its track and compartment design, the design and placement of architecture and its terminals- he posits, all shaped subjectivities and industrialized people's perceptions of movement, people, and places, (the latter of which ceased to be viewed as unique spaces and transforming into nodes on thoroughfares of railway circulation). It also produced new social modes, such as novel illnesses, or strategies for 
interacting with strangers in confined and noisy spaces. In her study of the politics of dis/comfort, Chu (2016) suggests that the vehicle is an ideal spatial microcosm for studying social relations, particularly among strangers or 'Others' as well as "the limits of 'fellow feeling' or moral sympathy in a globalizing world" (Chu 2016:403). It is here, she argues, that we find technical-material aspects of vehicles entangled with social ideas, habits and aspirations (ie. railway as democratic travel).

De Certeau (1984) similarly examined how the materiality of the train mediates a railroad passenger's relationship to them self, fellow humans, and the natural world. The train, he argues, shapes the internal and external experiences of the passenger by incarcerating and immobilizing the traveller and the natural landscapes which they pass through. He refers to the windowpane and the rail line as the materiality which shape this im/mobililizing experience.

The windowpane is what allows us to see, and the rail, what allows us to move through. These are two complimentary modes of separation. The first creates the spectator's distance: you shall not touch; and the more you see, the less you hold - a dispossession of the hand in favor of a greater trajectory for the eye. The second inscribes, indefinitely, the injunction to pass on; it is its order written in a single but endless line: go, leave, this is not your country, and neither is that- an imperative of separation which obliges one to pay for an abstract ocular domination of space by leaving behind any proper place, by losing one's footing (p. 112).

The physical immobility of seating and cabin structures contrasts sharply with the very mobility of train and of the mind and spirit of the traveller, however. According to de Certeau (1984), the train's materiality separates the traveller from its environment, thereby stimulating his-her interior thoughts, dreams, fantasies: "Glass and iron produce speculative thinkers or 
gnostics. This cutting-off is necessary for the birth, outside of these things but not without them, of unknown landscapes and the strange fables of our private stories" (de Certeau 1984: 112). In other words, the separation and isolation may appear to be mere passive consumption of exterior stimuli, but it is not just this. It is also productive. It produces dreams, thoughts and ideas. It produces a subjective journey.

Similarly, Blue (2015) has also reflected on what de Certeau calls the “...incarcerational and navigational" qualities of railroad travel (1984: 113). Drawing on early twentieth-century fiction, Blue examines how migrants have historically experienced the deportation journey aboard special deportation trains in the United States. Special trains -known as deportation specials- were designated to criss-cross the country picking up those denizens who had been captured and channeling them toward the port- exit via rail. Blue (2015) argues that:

the trains' economies of scale allowed a massive deportation apparatus -based in institutions, beliefs, law and material infrastructure- to flourish....Along with accumulating restrictive immigration laws, the material apparatus of removal posed a vital step in the production of alienage and therefore citizenship...For migrants who somehow fell afoul of the law, deportation was a terrifying journey that would spatially and legally dismantle their claims to belonging. As deportees, they were literally cast-out (p. 176).

For migrants, the deportation journey consisted of three administrative zones, including a zone of initial incarceration and coerced immobility; a zone of coerced mobility from the interior of the United States to its edges (usually San Francisco or New York), and; a zone of island detention and expulsion. Each zone consisted of its own spatio-temporal and liminal experience of im/mobility. Blue suggests that in zone 2- coerced mobility aboard the trains- deportees 
experienced “...geographic travel, bodily immobility, and relative temporal fixity. This new configuration of space-time and motion took hold in deportees' bodies and produced listlessness and illness, and a new liminality" (2015: 181). Ashmore (2013) has examined how the material and social structures of ocean liners shape the passenger experience. He argues that, because passengers do not have any visual markers which help ocean liner passengers keep track of progress in their journey at sea, they are encouraged to turn to the socialities of the ship. These social interactions, he argues are configured through seating arrangements and shared spaces which are organized by social class.

Infrastructure is thus relational. It offers a medium through which social interactions can take place with the self, others and the environment. It has a different meaning and function for those who interact with it (Star 1999). A super highway built to connect and communicate the urban spaces of one social group can simultaneously represent a barrier to mobility and communications for other social groups and spaces (Rodgers 2012). The material and social structures of transport infrastructure selectively include and exclude individuals, sometimes producing novel mobility experiences, practices and figures-such as stowaways- who harness "the motive force of commodity networks... for unintended forms of corporeal mobility" aboard trucks, ships, trains and even airplanes (p. 1048). Stripped of the 'comforts' and encapsulated protections of legitimate travel, Martin (2011) argues that these passengers are exposed to the systemic 'violence of speed' which characterizes late Modernity.

Scholars have also suggested that we look beyond the materiality and sociality of vehicles, transport infrastructure and routes by interrogating how these are loaded with meanings and codes which shape engagement in the symbolic arena of migration politics. According to Larkin (2013), "roads and railways are not just technical objects then but also operate on the 
level of fantasy and desire. They encode the dreams of individuals and societies and are the vehicles whereby those fantasies are transmitted and made emotionally real" (p. 333). Vehicles and routes can thus signal progress, hope, integration, strength, fear or suspicion, and these ideas and symbols are often shared with those who use them. Thus, the reception of asylum seekers who arrive in a country by air, for instance, can be quite different from the reception of persons arriving by rusty ship (Ashutosh and Mountz 2012; Walters 2015).

Finally, it should be noted that infrastructures are dynamic. They constantly change to reflect and enact the values, beliefs and practices of society. Merriman (2016), for instance, challenges material and static notions of infrastructure through his study of UK carparks. He illustrates how car park infrastructure is constantly being recreated “...both socially and materially- requiring physical maintenance, gathering meanings and generating atmospheres" (87). He concludes that a more relational and processual conceptualization of infrastructure is needed in order to account for the interactive ways in which infrastructures produce -and are produced by- mobile subjects, emotions and ecologies. Similarly, in his ethnographic study of the roadside, Klaegar (2012) illustrates how the rhythms of Ghana's roadway mobilities shape the social interactions, entrepreneurial tactics and commercial transactions of street hawkers with roadside mobilities. The stops and starts, the periods of rushing and waiting, along with ecological factors, such as hills, heat, and road construction, all inform the mobile strategies that vendors utilize to engage the occupants of passing cars and buses. At the same time, the roadside interactions of vendors and passengers continuously reconstitute the roadway as infrastructure (Klaegar 2012).

Moreover, ecology continuously shapes the form, endurance, and capacities of infrastructures. Despite modernist attempts to conquer, isolate, extract, box, ship, and control the 
natural world, infrastructures are not autonomous from the natural environments in which they are embedded. Ecology fuels and nourishes infrastructures by offering the land, coal, and water for their anchoring and function. It also introduces novel problems for infrastructure. It twists, rusts, and embellishes the materiality, meanings and experiences of infrastructure. It mediates human sensitivities, dispositions, and capacities in relation to infrastructure. And it reminds us that we are not alone on this planet every time flocks of geese or puffs of volcanic ash infiltrate the flight paths of commercial airlines or a hurricane wipes out roads, housing, or cell phone towers.

It is for this reason that, although infrastructures regularly involve technologies and ideas which are developed in one setting and then standardized and distributed to other settings (Easterling 2014; Cowen 2014), the reproduction of infrastructures is not a copy and paste affair. Infrastructures must always negotiate and adapt to the natural and cultural ecologies where they engage. Railway technologies which are developed for service in the United Kingdom, for instance, must be adapted to negotiate the character and contingencies of tropical or arctic climes and landscapes. The materiality of the railway will react and interact with the land, air, water, and temperatures in very different ways. This gives rise to new sets of problems, as well as solutions which, for ecological reasons, will necessarily draw on distinct resources and dispositions. And, because ecologies are ever-changing, the challenges and resources which they can offer also change constantly. Ecologies thus form an integral part of infrastructures (Swyngedouw 1999). They interact with human processes in spatially and temporally-specific ways to produce unique problems, aims, logics, practices and dynamics for the governance of mobilities. 
Efforts to understand the ways in which infrastructures and ecologies interact to govern mobilities fall in line with recent scholarship which seeks to challenge dominant understandings of our social world as exclusively human and apart from all other living beings. Netz (2004), for instance, argues that humans, animals and land share a history, and make history together by virtue of the fact that they share the same space and therefore must interact. Furthermore, he argues that the ways they interact changes over time and that technologies, such as barbed wire or railways, play an important role in mediating and reconfiguring the interactions among humans, animals and space, particularly in the age of modernity. Furthermore, Netz (2004) argues that “...all living beings have desires and move about, and so they shape reality as well...there are no extras, and they are all actors- humans, animals and their shared terrain. And it is because all these actors occupy the same stage, they cannot fail to interact; no species is an island..." (Netz 2004:228). Massumi (2014) similarly argues that the social and political interactions of humans are not that different from those of animals; thus, animals offer many opportunities for better understanding ourselves.

Accounting for ecology also serves as a reminder that human-built infrastructure does not work in isolation. Ecology interacts with infrastructures to produce and shape mobilities, including migrations. This notion offers significant symbolic and political 'friction' (Tsing 2005). Foregrounding the vital character of the railway serves to counter the criminalizing and morbid narratives which have participated in the symbolic reconstruction of many railways in the post-industrial era. It also suggests that there is value in preserving Mexico's railway spaces and histories, which are in danger of being forgotten or buried under the countless news reports about criminality, conflict, injury and death.

\section{On Counter-Memories and Genealogies}


"There is no document of civilization which is not at the same

time a document of barbarism" Benjamin 1968: 256).

Genealogies are critical devices. They are histories that are written against present-day truths which claim that the origins of contemporary 'crises' can be found in universal and generalized processes, such as securitization, globalization, and neoliberalization (Foucault 1977; Dean 2003). They draw our attention to knowledge and memories which either do not 'fit,' or which actively contest, the dominant narratives of the day. They examine these memories and ask how they alter the way we see or know the world today (Foucault 1977; Benjamin 1968; Said 1993). Thus, genealogies - and the counter-memories they uncover- are a means of stirring the epistemic pot. They aim to generate debate where conversations have fallen silent.

Genealogies make us conscious of the politics of memory and knowledge (Foucault 1977; Medina 2011). By bringing to the fore those memories and knowledges which have been marginalized or criminalized, these radical histories remind us that how we see the present or the past is continuously subject to political struggles. By reviving forgotten memories, they prompt us to ask critical questions about which knowledges dominate and which knowledges have been buried, masked, marginalized and even forgotten and why. Thus, genealogies have the potential to raise critical questions about what we think we know about the world today. They can challenge current power structures and world views.

Like historical sociology, genealogies draw on historical materials as a means of gaining new insights into the social and political struggles of the present. Nevertheless, genealogies differ from other approaches in that they reject the idea that there are 'universal laws and trajectories' which govern human nature and the historical 'evolution' or development of social 
life (Foucault 1977; Walters 2012: 16-17). They critique understandings of history as 'Truth' or as a timeless essence which is waiting to be discovered. They are also critical of the tendency to apply present-day concepts to the past as though these would carry the same meaning and be equally applicable to peoples across all time and space (Foucault 1977).

Genealogies reject the pursuit of origin and the presentation of linear development models of history (Foucault 1977). Instead, genealogies offer events-based histories. Events can be defined as moments in which a novel practice or idea emerges in response to the problematization of existing ideas or practices and a shift in the balance of forces (Walters 2012; Foucault 1977). Events-based histories begin with what might be an apparently natural unit, idea, or practice today, and they trace how this unit emerged or came into being. To do this, genealogies deconstruct the unit. They locate its fissures and constitutive components, and they trace the processes and contingencies which drew together its various parts and transformed them into the apparently solid, harmonious and natural 'whole' (unit) that we take for granted today.

This process of "liberating a profusion of lost events" (Foucault 1977: 145-146) is what Foucault (1977) calls the analysis of descent. He argues that: "The search for descent is not the erecting of foundations: on the contrary, it disturbs what was previously considered immobile; it fragments what was thought unified; it shows the heterogeneity of what was imagined consistent with itself" (147). And, in this way, genealogies de-naturalize phenomena, underscoring the multiplicity of processes and the contextual specificity of the problems, and contingencies which gave rise to and transformed the practices and ideas which dominate today.

As events-based histories, genealogies do not offer detailed chronologies of past occurrences. Nor do they aim to provide a comprehensive, objective Truth. They offer historical 
snapshots, or counter-memories, which often lack a beginning or an end. As Walters (2012) observes, Foucault's genealogy of the government of state, covers enormous spans of time -from ancient Greeks and Romans to neoliberal ideas. This, he says, is only possible because:

...he approaches historical change not as a conventional historian might but as a genealogist. He makes no attempt to write a total or general history of arts of government. Instead, he focuses on selected 'events' -situations where the problematization of existing ways of governing, and reflections on different ways of governing can be identified (p. 21).

It is for this reason that I may appear to weave in and out of historical periods in the chapters that follow. Rather than attempt to reconstruct a whole chronology of La Bestia which covers every moment from day one up until the present, I have chosen to focus on counter-memories and events that serve to denaturalize the many assumptions that are commonplace today after more than two decades of globalization and security narratives.

Each counter-memory presented in this dissertation spotlights the rich tapestry of local knowledges, stories, landscapes, mobilities, symbols, actors and practices which have been discarded or silenced because they do not fit simplistic security stories of threatening migrants or migrant victims who need to be saved. It foregrounds knowledge which has been cast aside, forgotten, or dispersed, and it underlines its potential to change the way that we see, experience, and interact in the world today. In doing so, it posits that our knowledge of the past exercises power in the present.

Methods: The Case, Data, Analysis, and Limitations 
As noted earlier, I selected La Bestia as the site from which to deconstruct the global migration crisis because it was a site of highly-visible, dangerous migration journeys and a contemporary battle ground for the politics of migration and security. It offered an excellent site to craft new theoretical perspectives and conceptual tools which serve to examine these hypervisible migration journeys in a different light. Furthermore, as noted earlier in this chapter, very little of the research on migration, vehicles, routes and infrastructure has examined how the materiality of railways produces unique political problems and strategies where migration and infrastructure are concerned. I therefore considered La Bestia an excellent site from which to explore what a politics of migration might look like through an infrastructural lens. In other words, I saw the potential contribution I could make to studies of mobility, migration and infrastructure. Finally, my previous research experience in Central America and Mexico (20032014) -as a graduate student, a research assistant, and an intern- offered me a solid foundation upon which to build this project and contribute to public and scholarly debates about key migration issues in the region.

Drawing on Xiang and Lindquist (2014)'s work on migration infrastructure, I defined La Bestia as a space, where heterogeneous networks intersect, co-opt and conflict with one another as they facilitate migrations and other mobilities which occupy the space. Each network moves migrants according to its own set of aims, rationales and practices, and it must negotiate their interests with others who also inhabit this space. According to Xiang and Lindquist (2014), migration infrastructure's networks are heterogeneous assemblages of human and non-human elements, which can be loosely categorized into one of five dimensions: Regulatory, Commercial, Humanitarian, Technological, and Social. As these networks push up against and interact with one another, they produce an effect on migration. 
In their own work, for example, Xiang and Lindquist (2014) found that the intersection of networks which facilitate labour migrations from China and Indonesia has produced an ‘infrastructural involution' effect, which makes labour migration simultaneously more and less accessible to migrants. It is in this sense that La Bestia might be thought of as a space of interstice, a non-place of emergence, where power struggles play out, and any shift if the balance of forces can produce an event.

Finally, to trace how La Bestia emerged as a migration infrastructure, I identified four of its constitutive dimensions- regulatory, humanitarian, material, and symbolic-mediatic. For each dimension, I noted key actors and practices which facilitate migration on the railway. I then used genealogy as a method for tracing where these practices came from, as well as how they transformed and came together over time, that is, how they came to constitute what we know today as The Beast that Devours Migrants, or La Bestia.

To do this, I drew on both primary and secondary data collected between 2012 and 2015 on four separate field trips to diverse cities in Mexico. During this period, I conducted a total of fifteen in-depth interviews in Spanish; I consulted newspaper archives; I consulted archival material relating to the railway and migrant protection, and I utilized Google ebooks and the newspaper database Factiva to access early 20th century newspaper publications and other key historical documents. I transcribed and coded the interviews, and I translated the passages which were selected for presentation in the dissertation.

To get a sense of everyday railway practices before and after the emergence of La Bestia, I conducted five interviews with local residents who had either worked, travelled or lived near the railway during this period. These included a local vendor (bayunquero), family members of railway workers (rieleros), and residents of railway neighbourhoods. To trace the practice of 
charging migrants piso on La Bestia, and the subsequent arrival of humanitarian actors and protection practices in southern Mexico, I conducted nine interviews with persons actively involved in the politics of protection. These interviews included state officials, members of the network of migrant shelters, civil society educators and activists, as well as two Central American migrants who had travelled by bus and railway through Mexico in the early 1980s. I also consulted material on Beta Groups (see Chapter 5 - The Politics of Protection) in the Library of the Migration Policy Unit (Biblioteca de la Unidad de Politica Migratoria) in Mexico City.

Archival data and newspaper articles offered data that was important for reconstructing the emergence of a politics of representation, a key dimension of the migration infrastructure of La Bestia (see Chapter 6- The Politics of Representation). Newspapers were consulted in three locations: At the offices of El Orbe in Tapachula, Chiapas; in the Hemeroteca of the Biblioteca Nacional at the Universidad Nacional Autónoma de México (UNAM) in Mexico City, and; online through the database Factiva. Archival data was also consulted at the AGN in Mexico City and in the library of the CEDIF at the National Railway Museum in Puebla. These documents were important for understanding how and why changes were made to the material and administrative operations of the Panamericano railway. Google eBooks was also an important source of several nineteenth-century publications which have been digitized and made available to the public free of cost.

The focus of my in-depth interviews was limited to two themes: 1.) The illicit practice of charging 'derecho de piso' (the use of violence to tax movement through a particular territory) and how diverse social actors facilitate migration in such a context, and; 2.) Local histories of railway mobility and migration, particularly prior to the rise of La Bestia. My scholarly curiosity around the history of charging 'derecho de piso' as a lesser-known mode of regulating migration 
conflicted regularly with my desire to denaturalize the security narratives and practices of $L a$ Bestia and give voice to the local railway passengers, workers, and neighbourhoods that were dispossessed of their livelihoods and spaces as a result of the very same processes which contributed to the production of La Bestia, These two dimensions of my project always seemed to be at odds with one another, and, even in the final drafts of this project, I cannot say that I have resolved this conflict. Consequently, my writing on these topics is marked by this tension and an underlying concern that the data I present on derecho de piso could be used to feed the very same narratives of barbarous and beastly Mesoamerica that I wish to counter through my work.

Secondly, many of the local newspapers published along the Pacific Coast of Chiapas and Oaxaca over the twentieth century either had short lifespans or their collections were limited at the Hemeroteca at UNAM. The best newspaper sources found were El Diario del Sur, El Sol del Soconusco and El Sol de Tonalá. The most important newspaper source reporting on the Panamericano during the second half of the $20^{\text {th }}$ century was El Diario del Sur. Unfortunately, (and maybe not coincidentally) there was a gap in this newspaper collection from 1988 to 2004, precisely the period when La Bestia emerges and takes the international stage. Consequently, I was unable to locate a single newspaper source which I could use to reconstruct a full historical series. I attempted to fill in this gap in media coverage by referring to articles published in $E l$ Orbe, a local newspaper published in Tapachula, Chiapas.

In El Orbe, I was able to locate some images and reports of the emergence of La Bestia (ie. first riders) and its radical transformation as a consequence of Hurricane Stan. Nevertheless, the 1990s and early 2000s collection from El Orbe was not itemized, organized, or complete since many publications had been damaged or destroyed as a result of hurricanes, humidity, and 
poor storage facilities. Finally, it should be noted that newspapers have long been restricted in their freedom to publish in Mexico. Thus, any analysis of newspaper data must be done with this in mind: the reporting of events must be seen, not as an objective picture of what happened, but rather as a material product of the politics of representation.

\section{The Main Arguments and Structure of the Dissertation}

As a means of enriching our understanding of the politics of migration, this dissertation goes beyond securitized accounts of autonomous migrants and states to showcase the great diversity of actors, interactions and political dances involved in the production and mediation of migration across railway time and space. As a counter-point to the contemporary depictions of threatening/threatened transit migrants and demonic railways in Mexico that are commonly found in the media, this project draws on in-depth interviews and archival data to spotlight a broader array of the actors and processes which have contributed to the emergence of highlyvisible, dangerous migration journeys on La Bestia.

In this dissertation, I argue also that these counter-memories can shed new light on the global migration crisis. I offer this argument with a word of caution, however: The sources of these subjugated knowledges are not likely to be the ones we think they are. In the field of migration studies, particular where studies focus on unauthorized migrations, there is a tendency to only see the migrant as downtrodden and vulnerable, invisible and unable to speak. As such, these migrants are automatically seen as the source of subjugated knowledges (in part because of securitized assumptions that migrants as victims or threats). This dissertation does something else. It spotlights the migrants and mobilities which no one has 'seen' on La Bestia because they do not fit with security frameworks: Humanitarian actors, state officials, organized criminals and journalists. Since the 1990s, many of these actors have migrated to and settled in southern 
Mexico in order to extend their networks, offices and organizations into the region. Hidden in plain sight, these migration stories offer valuable insights into the constitution of La Bestia.

The dissertation presents six counter-memories. The first counter-memory (Chapter 1) counters the idea that migration is new to southern Mexico and menacing to state security. It tells the story of how and why the material infrastructure of the railway was assembled with the mobility of ideas and people, including migrants. It describes the diverse aims and features of the assemblage and it recounts how ecology was mobilized, together with the railway, to attract a diversity of migrants- settlers, labourers and investors- to the Pacific Coast lowlands of Chiapas and Oaxaca. This chapter illuminates a moment in which migration was deemed the solution to Mexico's security problems and vital to the consolidation of Mexican territory and population. It also suggests that this state-making formula, involving -ecological inventories-settlement and railways- was common to other parts of the Americas, and it relied on migrations that were variegated and interdependent.

Chapter 2- counters beastly stories and images by spotlighting the lesser-known everyday railway mobilities of the Panamericano during the 1950s. This chapter suggests that Mexico's post-revolutionary state-making formula ignited a mobility politics of speed to the Pan-American Railway. The inauguration of the Pan-American Highway, along with the circulation of cultural inventories and tourist mobilities, pits the interests of railway workers and local mobilities against those of international tourists and the migrant settlers who engaged in commercial export producers. This mobility politics of retraso, I argue, produces symbols of counter-modernity which bear striking resemblance to those in circulation today. It also leaves a political legacy, which sets the stage for migration politics on La Bestia. 
Chapter 3 -traces the processes and effects of the administrative re-structuring of the Panamericano. It suggests that, during the 1990s, there was another shift in infrastructural statemaking, which involved railway restructuring, unsettlement, and; human inventories. This chapter locates railway restructuring in Mexico within a context of global infrastructure reforms, and it illustrates how the restructuring of the railway virtually eliminated railway passenger services; expelled and dispossessed the locals of their railway livelihoods, and; created jurisdictional nebulousness, which, coupled with the railway's historic tortuguismo (Chapter 3$)^{6}$, sets the stage for the emergence of a new type of railway passenger (Chapter 4).

Chapter 4- challenges the separate study of deportations and migrations by bringing these into a single analytical frame. It tells the story of how migrants came to ride on top of freight trains in Mexico. The chapter traces the un/settlement and deportation of populations in Mexico and the US between 1988 and 2005, and it connects their displacement to the emergence of transit migrants atop the cars of freight trains in Mexico. Unlike the dominant narratives which find the origins of La Bestia in the darkest and most lawless corners of Central America, this counter-memory suggests that the origins of the great 'invasion' decried by so many in North America can be found in the unsettlement of populations living in the United States and in Mexico. This chapter argues that, because of the railway's materiality (ie. the historic tortuguismo presented in chapter 2) and the jurisdictional nebulousness and absence of passenger services which resulted from its administrative restructuring (chapter 3 ), the railway becomes a space for unsettled populations to find refuge from the state authorities.

\footnotetext{
${ }^{6}$ Tortuga means turtle in Spanish. Thus, by tortuguismo, I refer to the slowness of the railway. Chapter 2 examines tortuguismo as a social movement in which railway workers slowed their production pace to protest their working conditions.
} 
Chapter 5 sets aside perilous stories of transit migration journeys, and, instead, turns our attention to another migration phenomenon which has received much less attention: The state and non-state actors who migrated to southern Mexico during the 1990s to intervene in the movement of transit migrants on La Bestia. Focusing specifically on the migration of the Beta Groups, this chapter argues that the actors who migrated during this period all originated from organizations and institutions first established in the North (United States and in North or Central regions of Mexico). As such, the arrival of these actors in southern Mexico suggests an extension of these Northern networks into the south, and a twenty-first century mode of colonization. Secondly, these actors intervened in transit migration in the name of protection and they used similar technologies to do so. What differentiates these actors, however, is their use of violence.

Chapter 6 traces the emergence of La Bestia, or The Beast that Devours Migrants, as a symbolic representation of the Panamericano. Counter to popular narratives, which trace the origins of this symbol to the migrants themselves, this counter-memory finds its origins and transformation in the United States. I argue that, over time, diverse actors have collectively built La Bestia and come to use it as a tool for shaping or influencing the movement of peoples in the region. The chapter ends by highlighting the ways in which local populations have sought to contest these beastly representations of the railway and their communities.

Together, these counter-memories argue that the rise of highly-visible, dangerous migration journeys in Mexico can be understood as the political effect of a new type of migration infrastructure. This migration infrastructure, I contend, emerged during the 1990s, in response to processes which were set in motion by the introduction of a new blueprint for liberal statemaking. I suggest that La Bestia is an example of this new type of migration infrastructure, and that, by studying how it came into being (through genealogy), we can better document those 
processes which gave rise to and continue to reproduce highly-visible, dangerous migration journeys in Mexico. This infrastructural lens offers the possibility of developing an alternate account of the politics of migration and attends to the material and non-material means of movement, a wider array of governmental actors, processes and technologies, and the question of research ethics

My research also suggests that we pay more attention to the ways in which one type of mobility is fundamentally connected to and influenced by other mobilities, such as capital, natural resources, symbols, and ideas. One of the main claims of my work is that any politics of mobility is also a politics of state-making. I also suggest that infrastructure, and particularly transport infrastructure, represents a key site and tool within this mobility/state-making politics. Infrastructure is profoundly political, unstable, and always in motion (Guldi 2012); it is constantly being (re)created by the practices of a diversity of actors; this in turn, continuously shifts the possibilities for shaping movement as well as the contours of the state. Therefore, by tracing these subtle shifts over time, we can discern patterns in connectivity and expand our understanding of power and mobility beyond the state.

The core argument that this dissertation offers is that infrastructure and mobilities make states, but how this occurs changes with time. In Mexico, we see at least three modes of (infrastructural) state-making since the end of the $19^{\text {th }}$ century. We encounter the first mode in Chapter 1, which illustrates how ecological inventories were produced and circulated to stimulate the movement of people necessary to build the Pan-American Railway. The creation and settlement of this railway infrastructure space, I argue, offers a means of capturing the territory of the Soconusco. Chapter 2 suggests that, because the railways were 'taken' during the revolution, post-revolutionary state-making shifted toward the construction of roads and the 
production and circulation of cultural inventories to stimulate tourist mobilities. The creation of alternative infrastructure spaces (roads, but also hotels, restaurants, gas stations, and other tourist infrastructure), I argue, offers a second chance to capture territory after the Pan-American Railway fails to offer adequate conditions for infrastructural state-making. and state-making in southern Mexico.

The final three chapters suggest that state-making has shifted once again at the turn of the twenty-first century. State-making today involves widespread infrastructure reform (chapter 3), the forced un/settlement and containment of populations (chapters 4 and $5^{7}$ ), and the production and circulation of images which securitize (chapter 6). The restructuring of the railway, I suggest, creates fissures in this infrastructure space for state-making which, today, centres on capturing populations and bringing them under state government in various ways.

\section{A Final Word: On Power and Terminology}

Power permeates terminology. It can thus manipulate the ways in which we see, interpret, narrate and experience a social world or process. This is a question that challenged me regularly while working on this dissertation. During my field research, I was told by more than one informant that the phenomenon of migration on the railways in southern Mexico was a relatively recent one. Nevertheless, my research uncovered a great deal of migration history which is 'hidden' under the euphemisms and narratives attached to the privileged mobilities involved in the construction, operations, and use of the Panamericano.

\footnotetext{
${ }^{7}$ Unsettled mobilities stimulate a need to protect them; police, military, missionary, organized crime
} 
Migration is commonly defined as the process by which a person leaves a city, region or country to reside in another for an extended or indefinite time period. In migration studies, we differentiate among types of migrations. Usually these classifications make distinctions based on the purpose, directionality, legality, and period of stay involved in the movement: im/emigrant vs. transit migration; labour vs. marriage vs. forced migration; permanent, temporary, circular, seasonal, irregular migration and so on. These distinctions create the impression that movement is at the core of migration inquiry and terminology. Nevertheless, in practice, we regularly find that migrations involving individuals and social groups of privileged status are conceptualized using alternative labels which connote their movement from one place to another as ethnically, economically and/or politically privileged beings. The protagonists of these migrations are often not called migrants, but rather 'foreigners,' 'ex-pats,' '(nationalities)', 'settlers,' 'colonizers', among others. And so, it appears that the particularities of a person's displacement are not the only -nor at times even the most relevant- fact which is communicated when the concepts of migrant or migration are mobilized.

In order to explicitly reconnect the more privileged mobilities to their migration history, while still attending to the diversity of experiences stemming from the various social positions of migrant groups, in this dissertation, I have chosen to add the hyphenated adjective 'migrant' to the various labels proffered those mobilities of privileged social and political status. Thus, the reader will find terms such as 'migrant-settler,' which are seemingly redundant, but which are used to identify and visibilize historic migrations which are, today, either forgotten or buried under dominant representations of what a migrant or a migration looks like. 


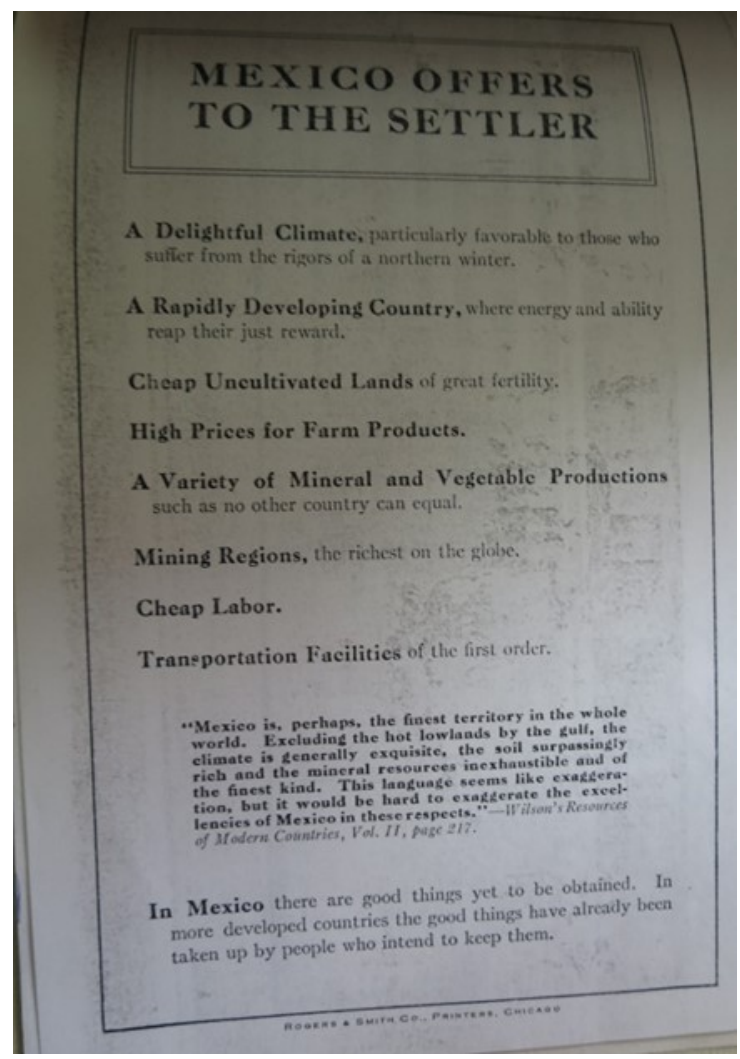

Figure 2- Poster 'MeXico OfFers the SETTLER'

Source: FNM. 1911. "Facts and Figures About Mexico and its Great Railway System the National Railways of Mexico.” Traffic and Industrial Departments of the National Railways of Mexico. México, D.F. Mexico: CEDIF Archive.

Before La Bestia, there was the Ferrocarril Panamericano. This chapter tells the story of how and why the material infrastructure of the railway was assembled with ideas, and people from around the world. It describes the diverse aims and features of this infrastructural assemblage, and it recounts how knowledge of the land's ecology was mobilized to attract migrants, technology, and capital to build infrastructure. The Panamericano, I argue, was born of efforts to make and consolidate a Mexican state. As this chapter suggests, late $19^{\text {th }}$ century state- 
making was not a haphazard venture in Mexico. It followed a blueprint which held the pursuit of 'material interests' as the best means of pacifying and building emergent modern states. In the Americas, material interests were pursued through the development of frontier settlements, railway infrastructure, and natural resource extraction for global export. This chapter examines the building of the railway and of Mexico as a modern state.

The chapter also highlights the re-emergence of Pan-Americanism as a discursive field which proposed that political and economic alliances among newly, independent modern states of the Americas be realized, both materially and symbolically, through the construction of a continental railway system, known as the Pan-American Railway (and later, as we shall see in Chapter 2- The Politics of Retraso, also a Pan-American Highway). This the Pan-American Railway aimed to connect all the capital cities in the Americas between New York City and Buenos Ayres through the integration of existing national railways into a trans-continental railway system. In Mexico, the missing stretch of railway which would link existing railways of Mexico and Central America to this trans-continental project was the El Ferrocarril Panamericano, or which also translates as the Pan-American Railway. In order to distinguish between the two Pan-American Railway projects, from this point onwards, I will refer to the trans-continental railway project as the Pan-American Railway, and I will refer to the stretch of railway which was constructed along the Pacific coast of southern Mexico between the Guatemala border and the Isthmus of Tehuantepec as the Ferrocarril Panamericano, or the

\section{Panamericano.}

\section{Building a Modern State}

At the end of the 19th century, the problem of states and migrations railways was very different from that which we are accustomed to hearing about today in Mexico. State security 
concerns lay not with restricting or regulating transit and emigration, but rather centred on attracting and retaining migrants to certain regions of Mexico to prevent territorial annexations and secessions. The dissolution of the colonial order in 1821 brought to the fore internal divisions which generated decades of violent conflicts in Mexico among conservatives and liberals; rural and urban regions, and the creole, mestizo and indigenous populations. The Mexican state also found itself constantly defending its territory from foreign annexation. In the north, Mexico ceded nearly half of its territory to the United States in 1848. In the south, the Soconusco, region of the province of Chiapas became a source of tension, as its political allegiance vacillated between Mexico, Guatemala and autonomy (Pineda 1845).

Borders were not the only colonial structure thrown into question with independence, however. The orientation of mobilities and transportation infrastructure were also profoundly affected. For hundreds of years, trans-Atlantic mobilities had shaped everyday life in colonial Mexico. The transportation infrastructure of the administrative territories of New Spain and the Captaincy of Guatemala had facilitated the movement of people and goods between the haciendas and mines of the interior and diverse ports along the coasts. In New Spain (Mexico), movement was facilitated by a system of roads built by the Spanish to connect Mexico's mining regions of the north with the colonial administrative capital (Mexico City) and the port of Veracruz, where ships were loaded with the riches of the New World to send as tribute to the Old World (Coatsworth 1981). Heavy freight originating in Central and Northern Mexico was transported using the Mexican carro, a two-wheeled wagon pulled by up to 16 mules, which, when placed in a train of thirty to eighty, allowed for the transport of mining and agricultural resources from one place to another (Coatsworth 1981:18). Together, colonial land and sea 
routes not only served economic ends but also served as powerful, symbolic lazos between the Old and the New Worlds.

Mexico's colonial roads fell into decline and disuse, however, as the massive transAtlantic extractivist project of the colonial regime was challenged by new political projects actors, and spaces which sought to found modern states based on the ideals of French and American Revolutions (Coatsworth 1981: 19). The problem thus became how to reimagine and retool the spaces, infrastructure and mobilities so as to nourish the development and longevity of a modern, independent state: Mexico

When Porfirio Díaz arrived at the presidency in 1877, the Mexican state had spent more than five decades fighting to establish and retain political authority over territory (Matthews 2014). For Díaz, attracting and retaining migrants to settle in the more remote and sparsely populated regions of Mexico was seen to be an act of defense against future invasion or annexation. Migration was also considered a possible solution to the rebellions and national disunity facing Mexico, particularly in relation to what was referred to as the 'Indian problem.' The goal was to build Mexico into a prosperous, modern state whose national identity was neither European, nor indigenous, but rather that of a mestizo child born of a marriage between two distinct civilizations. Migration, it was thought, could whiten and homogenize the Mexican population through miscegenation (mestizaje), thereby quelling ethnic conflicts inherited from colonialism. Finally, migration was also considered a means of acquiring the technology and knowledge necessary to modernize the state (Batalla 2012).

Nevertheless, attracting and retaining migrants was easier said than done given the political instability, economic stagnation, and poor transport infrastructure which had characterized Mexico for much of the nineteenth century. Furthermore, many of the remote 
settlement regions were hostile to migrant settlers and labourers. In some regions, it was a lack of fertile land or irrigation sources which made human livelihood impossible. In southern Mexico, high temperatures and the prevalence of disease posed major challenges to settlement for nonindigenous populations. Díaz was not deterred, however.

For more than three decades, from 1877 until 1911, Porfirio Díaz led Mexico through an aggressive economic and political program which aimed to stabilize and modernize what had been, until then, a precariously, independent, modern state. Central to this plan was the building of close to $20,000 \mathrm{~km}$ of railway lines and the use of foreign investment to modernize the exploitation of mining and agricultural resources (Coatsworth 1981; Gorostiza 2010). Thus, the construction of Mexico's national railway system is generally thought to be synonymous with a period in its history which has come to be known as the Porfiriato (1877-1911).

During this period, copper, ore, sisal, coffee, rubber, and livestock were harvested and exported to markets in United States and Europe using these new production and transportation technologies. Similarly, foreign financing during this period stimulated the development of domestic industries, such as cotton textiles, alcoholic beverages, food processing and other consumption goods which began to displace artisanal production of local goods and use the railway system to reach new markets in other parts of the country which had previously been inaccessible (Coatsworth 1981: 4). Foreign capital and a foreign demand for Mexico's goods were key ingredients of the Porfirian recipe for economic expansion in Mexico. As a result of these policies, economic and political influence of foreigners increased dramatically during the Porfiriato and landownership became concentrated in the hands of just a few. These two issues would later become the basis for the Mexican Revolution, an event which ended Porfirio Diaz's reign in 1911 (Coatsworth 1981: 4-5; Matthews 2014). 
The broader motivations and framework of railway development during Porfiriato was to employ Mexico's human and natural resources to the development of transportation infrastructure rather than military or political endeavours, which had been the focus of national energies and outputs since independence (Coatsworth 1981:43). Offering public concessions to private capitalists for the construction of the railways was politically strategic, as it put the onus (and therefore any failures) of these transportation projects on business owners and entrepreneurs rather than directly on the federal government. Thus, in terms of transportation, Coatsworth argues that:

The policy, as its official proponents asserted, involved a reliance on market forces and private, frequently foreign institutions to determine the pattern of Mexico's transport development. The perceptions of foreign capitalists and especially those of North American entrepreneurs projecting extensions of their U.S. interests in Mexico which could be harmonized with their previous commitments elsewhere (1981: 44).

Railroad construction thus coincided with an export-led model of development, and the patterns in the geography of the development of the railway obeyed existing interests of North American capitalists in Mexico. If there was a mine whose fruits North Americans wished to export to the U.S. or some other market, then a railway was built to facilitate this. If there were no capitalist interests in a particular region, or they were weak in funds and political clout, then railways were not built. As a result, some regions of the country were oversaturated with railway lines and other regions had few or none (Coatsworth 1981; Vanderwood 1981). As the dark lines on the map below illustrate, at the end of the $19^{\text {th }}$ century, there were no railways at all in southern Mexico while the centre and northeast regions boasted many railways. 


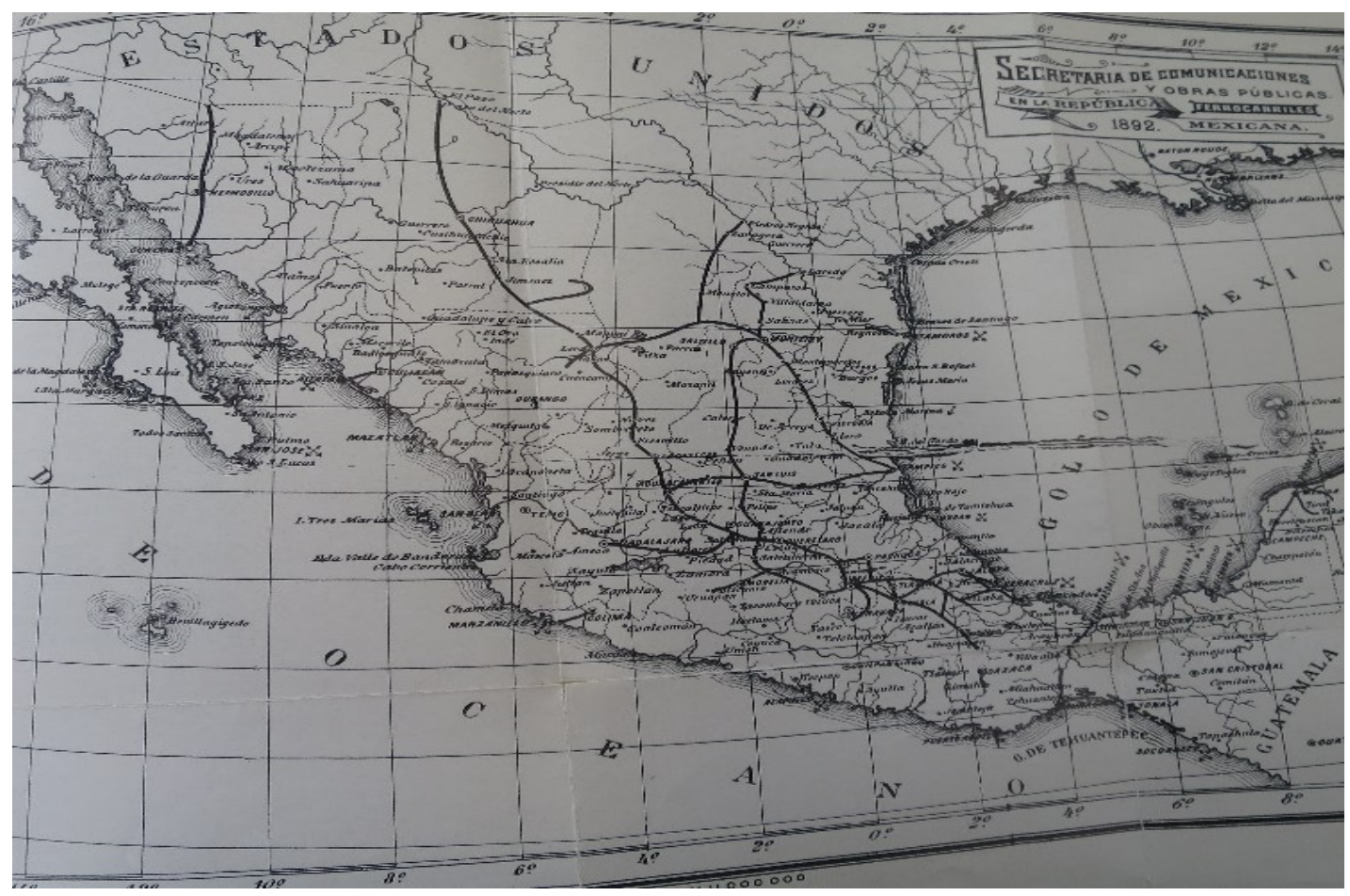

Figure 3- RAILWAYS OF MEXICO IN 1892

Source: SCOP.1976. Obras Públicas en México. Documentos para su Historia 2. Ferrocarriles de México. Reseña histórica- Reglamentos (Siglo XIX). México: Edición de la Secretaría de Obras Públicas. Mexico: Archivo General de la Nación (AGN).

\section{Material Interests.}

For U.S. railway investors, migration represented a different sort of dilemma than that which was facing the Mexican state. Building railroads presented an infrastructural dilemma which was reminiscent of the classic 'chicken or the egg' scenario. The feasibility and profitability of any railway construction project hinged on attracting and retaining migrants willing to settle and exploit the lands adjacent to the railroads in Mexico. Railway investment was thought to be risky without first having the migrant-settlers (ie. Railway passengers) in place beforehand. At the same time, it was thought impossible to attract or retain migrant-settlers 
without first having transport infrastructure in place to attract them (Gorostiza 2010). A debate emerged in Harper's New Monthly Magazine in the United States which illustrates this problematic.

In October 1882, John Bigelow published a 13-page article questioning the profitability and logic of investment by US capitalists in railway construction in Mexico. In this article, he expressed concerns over the security of private property and the transportation of goods given that Mexico was only just emerging from decades of conflict and brigandage. More importantly, however, Bigelow questioned the profitability of the investment. He argued that investment in:

...railway property which depends upon the industries and natural growth of the country, if not precarious, certainly does not promise to be very lucrative, unless some new elements of prosperity can be grafted upon it. This, we believe, is the conviction of all who have studied the question. All the schemes for new roads which have been presented to the American public have recognized it, and the new element upon which they all rely is emigration. Reasoning from their experience of railways in the United States, they assume that emigration will follow the locomotive through the wilds of Mexico as promptly and copiously as it had done through the prairies of Iowa and through the metalliferous deposits of Colorado and Nevada. In their imagination they see thriving villages springing up at every station and their rolling stock immediately taxed to its utmost capacity in transporting the merchandises which they consume and produce. It is from conclusions such as these that dreams are made. A few words will suffice to show how utterly delusive are all calculations based upon emigration as a railroad factor in Mexico (Bigelow 1882: 751). 
Thereafter, Bigelow (1882) takes several pages to explain why railway investors should not assume that migration would accompany railway constructions, thereby replicating the profits it had generated for investors in the United States. First, he argues, Mexico had not hitherto offered the types of incentives used in the United States to attract migrants, and that the country was not in a position to do so because there were no public lands on offer for appropriation. And while the US offered railway developers in the west enough tracts of land with their charters to, at minimum, return the cost of the railroad to its stockholders:

The Mexican roads, on the other hand, have no land grants; they have nothing to offer to emigrants but free passes over their roads to a country where they will be strangers, among a people whose language they do not understand, to cope with a climate, soil, and agricultural exigencies of which they have had no experience, and where they must compete with a laboring class that has been accustomed for centuries to live upon less than a shilling a day (p. 752).

Bigelow admits that the purchase of high-quality land was cheaper in Mexico than in the United States, and that emigrants did not have to deal with the harsh winters of the North. He also admits that Mexico's immigrant population had increased by 5,000 to 10,000 persons in recent years. Nevertheless, he argues that this new migrant population did not possess the qualities or characteristics required to generate railway profits since:

...it has mostly consisted of Italians and negroes, who have been brought here at the expense of railway contractors to work on the roads; and those of them who do not succumb to the climate will, when their contracts expire, either return to their respective countries or remain a burden rather than a source of wealth to their adopted country. There has been, and in the nature of the case there can be, no spontaneous emigration to 
Mexico until she can offer far different and greater inducements than she has yet been able to offer, or until the now vacant lands of the United States are practically withdrawn from the market. The element of prosperity, therefore, which has contributed so largely to build up the railway system of the United States, can not be counted upon in Mexico, and her railways must depend mainly upon the native industries and natural growth of the country, which, as we have already remarked, is estimated at an average of about one per cent, a year- an average which would doubtless increase somewhat with the increase of facilities, but to no very considerable extent for the first fifteen or twenty years (1882: 752).

A short time after the publication of Bigelow's article, Matías Romero, the Mexican Minister to the United States at the time, published a 32-page rebuttal in the same Harper's New Monthly Magazine. On the question of railway profitability and Mexican immigration, he remarks:

Mr. Bigelow takes a very disappointing view of Mexican immigration, but I think on that point he is mistaken. To be sure, as long as Mexico does not have railroads to afford cheap and easy facilities for transportation, it can hardly be expected to receive very extensive immigration; but as soon as means are placed within the reach of new corners, I have no doubt that immigration will flow into that country as it has into the United States. Mexico has a very fertile soil; where, for instance, fruits, which have a high market value, and very large profit, such as bananas, coffee, cocoa, etc. etc. can be cultivated. Lands can be obtained in Mexico, as Mr. Bigelow acknowledges, at a much lower price than public lands can be had in the United States. Public lands in the State of Chiapas, for instance, which is one of the richest states in agricultural resources, are worth now 50 
cents per hectare, which is equivalent to over $2 \frac{1}{2}$ acres, making its value about 20 cents per acre, and I doubt whether there is any richer or better land anywhere on the globe, except perhaps in the valley of the Nile. Public lands in Sonora is worth I believe only 12 $1 / 2$ cents per hectare. The land in Chiapas does not require any irrigation to raise the valuable tropical fruits named (Romero 1882: 21).

A year later, in December 1883, Mexico's federal congress passed the Colonization and Surveyor Companies Act (Ley de Colonización y Compañias Deslindadoras), which granted any Mexican the right to own lands considered to be vacant and to claim their titles (Molina 2006: 25). The federal government also invited (mostly foreign) survey companies to divide up, measure and value these lands, and, in exchange for their labours, surveyors were to be proffered land titles signed personally by Porfirio Díaz (Molina 2006: 25).

\section{Panamericanism and the Expansion of Frontier Economies}

The notion of Pan-Americanism is rooted in the early $19^{\text {th }}$ century period, a period in which independence from European colonial powers in the Americas. Simón Bolívar, a South American libertador, provided the writings and leadership of both an "idealized" hero and an "ideal hero of the Americas" (Brown 1935: 87). Simon Bolívar was thought to be the ideal Pan American hero throughout the Americas since he had proposed "that erstwhile colonies of the Western World should be free and independent republics, not monarchies," and they should form a confederation (Brown 1935: 87). Bolívar's first attempt at Pan-Americanism was in 1826 at the Congress of Panama, where he proposed this confederation be established through treaties and a common international law of the New World (Brown 1935: 89) in order to provide a source of conflict resolution among the newly independent states, adding to existing cultural unity, a source of juridical and judicial unity. The Congress of Panama was not well-attended, but 
Central America and Mexico were there. Bolívar died in 1830, at which point only a few spaces in the Americas had not become Republics (Belize, Canada, and the Guineas, for instance, were still tied to European colonial powers) (Brown 1935).

Bolívar's ideal of Pan-Americanism was revived in 1889 at the First Conference of American States in Washington state, and this is where the Pan-American Railway was first proposed (Salvatore 2006). According to Salvatore (2006), the Panamerican Railway was to contribute to the construction of an intercontinental railway that would connect all of the capitals of the American republics. At this conference, he says, Secretary Blaine called on the Latin American countries to cooperate in the design and construction of this system, stating that:

We believe that we should be drawn together more closely by the highways of the seas and that at no distant day the railway system of the North and South will meet upon the Isthmus and connect by land routes the political and commercial capitals of all Americas (Caruso 1951 as quoted in Salvatore 2006: 674).

Following the conference, the U.S. Congress established an International Railway Commission, approved the necessary funds for conducting pre-construction surveys, and designated influential railroad builder Henry Gassaway Davis at the helm (Salvatore 2006: 674; New York Times 1904). Over the next few years, the Army Corps of Engineers solicited and carried out surveys along the proposed route and published its findings in five volumes between 1895 and 1899 (Salvatore 2006: 674; Molina 2006: 38). Its 1896 report estimated that the route from New York to Buenos Ayres (sic) comprised a total of 10,471 miles, of which 6,702 were already in operation (New York Times 1904).

\section{Material Interests Arrive in the Soconusco.}


During the 1880s and 1890s, while the rest of Mexico was abuzz with the sound of steam locomotives and mining industry, southern Mexico was quiet. On-land, mobility was limited by climate, terrain and distances, as well as the availability and willingness of different beasts of burden to make the journey. Horses, mules and oxen transported both goods and people along a small number of rustic trails, or carreteras, which ran from the Gulf coast to the Pacific Coast and up towards Mexico City via the Tehuantepec Isthmus (Sibaja 2000; Castañón [1951] 1989). Carters accompanied ox-drawn wagons filled with merchandise to be bought and sold en route. Women and children without sufficient resources to travel by horse would often pay carters to secure a space in caravans of wagons (Traven 1949: 84). The use of people and beasts of burden to make difficult trek along roads which looked more like mule trails of rugged character and near impossible passage for wheeled vehicles (Molina 2006; Castañón [1951] 1989).

In Chiapas, the carreteras still obeyed colonial structures of mobilities, as they latitudinally connected the populations and spaces of the highlands of Chiapas, particularly the political centres of San Cristóbal de las Casas and Tuxtla Gutiérrez. The ranchos and towns which dotted the length of The Pacific Coast Lowlands of Chiapas, however, were relatively isolated from these colonial centres, however. The absence of roads and in-land navigable waterways isolated the inhabitants of the Pacific Coast Lowlands of Chiapas. particularly during the rainy season when many of the colonial carreteras became impassable.

In the 1860s, shipping companies, such as The Pacific Mail (US), The Pacific Steam (British), Kosmos Line (Germany) and Compañía Naviera del Pacífico, S.A. (Mexican), began to run steamship services along the coast from Panamá north to Mexico, with stops in Central America, as well as services from San Francisco, California, south to Mexico (Castañón [1951] 1989). In 1861, President Benito Juárez had officially set up a port in Tonalá for commerce with 
the exterior. La Puerta de Tonalá or La Puerta (today known as Arista) became the major 'port' for Chiapas. It was small and rustic, but it facilitated the movement of people and merchandise along the Pacific Coast of Chiapas. In 1874, the port was set up with a cableway 'andarivel' to facilitate the arrival of steamships. By 1887,616 packages, valued at $\$ 49,104.40$ had been exported through this port to New York, San Francisco, Hamburg London, Burdeos and Corintho (Castañón [1951] 1989: 302).

On June 26, 1890, the first train ran in Chiapas between Puerto Arista and the town of Tonalá. Built by la Compañia Limitada del Ferrocarril Mexicano del Pacifico, of combined capital from New York, London and Germany, the train connected the sea traffic with existing roads, facilitating the transport of goods and people between the two. At the time, Puerto Arista was nominally and in practice La Puerta of Chiapas, or the port, for the international traffic of goods and people (Molina 2006: 20). On the day of this tiny railway’s inauguration, a telegram was sent to the Governor of Chiapas, communicating the event and declaring that the Chiapanecan people now marched on the path of progress ("the pueblo chiapaneco marcha por el sendero del progreso" (Castañón [1951] 1989: 301, author’s translation).

According to Castañón ([1951] 1989), it was in 1892 that Chiapas decidedly took action with regards to transport infrastructure, opening up mountains and valleys to promote communication with the interior of the state and the rest of the country (303). In 1892, Rabasa renamed La Puerta Arista. It was equipped with a lighthouse to further facilitate the sea traffic of steamships which ran up and down the Pacific Coast between Panama and San Francisco. There were four major steamship lines, each run with capital from a different country: US; Britain, Germany and Mexico. In 1889-90, 237 arrivals and 172 departures of passengers were registered. 


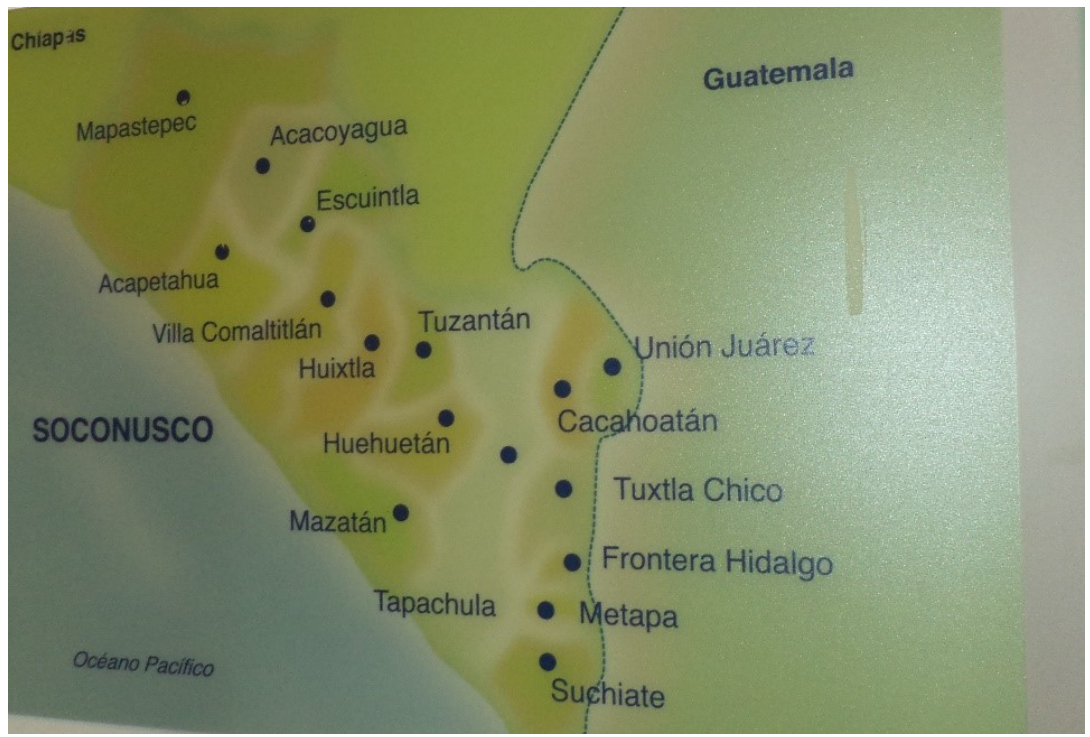

Figure 4 Map of the Soconusco ${ }^{8}$ (Chiapas).

Source: Exhibit at the Soconusco Museum of Archaeology. 2012. Tapachula, Mexico.

\section{Ecological Inventories}

The 1890s were known as the decade of 'spread-eaglism,' as the Mexican government embarked on an aggressive campaign to promote the demarcation, colonization and exploitation of public lands in the state of Chiapas, as well as the construction of both land and maritime transport infrastructure, including the railroads. With financial and other supports from an elite group of Mexicans known as los Cientificos, along with the support of diverse 'promotores'

\footnotetext{
${ }^{8}$ Soconusco derives from the word Xoconocho, which, in the Nahuatl, means "place of sour prickly pears" (tunas agrias). The region has hosted human settlements for approximately 5,000 years and has long been an important site for economic and cultural exchange between peoples in present-day Mexico and Central American. In the $16^{\text {th }}$ century, the region paid tribute to the Aztec (Mexica) empire. Under colonial rule, it was administered, along with the rest of Central America, by the Captaincy of Guatemala. Today, the Soconusco is one of the eight administrative entities which comprise Mexico's southern state of Chiapas ( Exposition at the Soconusco Museum of Archaeology).
} 
(essential salespersons), President Díaz made every effort to bring foreign capital, technology settlers to Chiapas (Molina 2006: 39).

Attracting and retaining migrants to remote settlement regions was no easy feat, however. During this historical moment, modern states around the world competed with one another to attract migrants and entrepreneurs who would help to consolidate their territories by populating remote areas and connecting them through modern infrastructure. To attract investors, settlers and labourers, governments and chambers of commerce in Mexico took stock of the ecological features of the region and its potential utility as a means of selling commercial opportunities to foreign investors. They packaged these ecological inventories and circulated them internationally.

In 1895, for instance, Ramón Rabasa ${ }^{9}$ published a guide to Chiapas, entitled El estado de Chiapas: geografia y estadistica, recursos del estado, sus elementos, condiciones de riqueza, porvenir agrícola. Rabasa's publication provides a panoramic view of the state of Chiapas, including the geography, agricultural-commercial products, population and the organization or structure of government. It offers a whole section called "Informaciones sobre Chiapas," a more accurate title for which might read "the art of commercial agriculture in Chiapas" since, for more than 50 pages, Rabasa offers a step by step guide on how and where to cultivate coffee, coconut, tobacco, sugar, rubber, achiote, indigo and cacao. Part 3 of the text offer statistics of the state, focusing in on the population, land use, and exports. There are also many pages dedicated to the average temperatures in each settlement or district of the state.

\footnotetext{
${ }^{9}$ Ramón Rabasa was one of the founders of the Bank of Chiapas, which was fundamental in the financing of the Panamericano. He was also brother of the then Governor of the state of Chiapas, Emilio Rabasa. He was thus an active part of the elite circle of Científicos who worked to implement the modernization project set out by Porfirio Díaz (Molina 2006).
} 
Finally, Rabasa includes a section entitled 'itinerarios' which offers readers a snapshot of transport and communications in the state of Chiapas. It offers detailed information about distances between diverse departamentos (a sub-division of the state akin to a county or a district) and their relative distances to the most important political and economic centres of the state. It also offers detailed itineraries of existing transportation and communications infrastructure, including coastal routes, boat rental agencies, international steamship schedules, tariffs for cargo transport, and suggested land routes. On page 136, for instance, Rabasa offers communications knowledge for travel on land from Tonalá to Tapachula. As the reproduction of this table illustrates below, the itinerary maps out where a traveller or settler can find telegraphs, towns, and haciendas along that route.

It is worth noting that of all the itineraries (ie. transport and communications overview) which were provided in this publication, this was one of the few with a caveat at the bottom. It stated:

The route follows the flat part of the coast and, with little work, it will be made a road. It is easy to use in the dry season. In the rainy season, the rivers grow and some of them are dangerous because of their strong currents. The worst rivers are 'Novillero', close to Mapastepec; the Cintalapa River in Escuintla; the rivers of Huistla and Huehuetán, and the Coatán River on the periphery of Tapachula (Rabasa 1895: 136, author's translation $^{10}$ )

\footnotetext{
10 "El camino sigue toda la parte plana de la costa, y con poco trabajo se hará carretera. En la época de las secas no presenta inconveniente alguno. En la de lluvias, los ríos se crecen y alguno de ellos son peligrosos por la impetuosidad de sus corrientes. Los peores son el de 'Novillero', cerca de Mapastepec; el de Cintalapa, en Escuintla; el de Huistla; el de Huehuetán y el Coatán, a orillas de Tapachula" Rabasa, 1895. P. 136).
} 
Two years later, in Los Angeles, California, William W. Byam publishes $A$ Sketch of the State of Chiapas, México. The 82-page book draws a significant amount of its content from Ramón Rabasa's 1895 Spanish-language publication, and it adds the views of Ramón's brother, Emilio Rabasa, the Governor of Chiapas. It also features maps, photos and illustrations of the people, plants and settlements of Chiapas, which Byam himself collected over a two-year period of travel in the region. A whole chapter is dedicated to the topic of colonization and settlement, and the matter of accessing world markets. It sells colonization to the migrant-settler in a very direct way, stating:

The man of middle age in the United States has fairly witnessed the beginning and end of the settlement of the states west of the Mississippi river. This settlement has been sufficiently complete, as least, to close all lesser avenues of money making, save only to those of ample capital; a result that leaves the average man 'a hewer of wood and a drawer of water,' with little hope of improving his condition. However, with the opening up of these southern countries, with their untold wealth and possibilities, to American settlement, has come again the chance of a life-time for the man of spirit and enterprise who, by seizing the opportunity thus presented, will find it possible to secure for the future that sought for boon- a comfortable income independent of daily toil. It is said that: 'The Genii OPPORTUNITY knocks once at each man's door, but if unheeded, hurrying on, returns to knock NO MORE (Byam 1897: 76-77).'

As Rabasa and Byam published their guides to Chiapas, President Porfirio Díaz was actively sending promotores to all the major cities in the United States where investors might be 
found- Kansas, Nebraska, Chicago, San Louis, California, and Boston -and gave them terrains (tierras en su punto) which were already to harvest coffee, rubber, chicle (gum) or precious woods (Molina 2006:39).

José Mora, who was close to President Díaz, was charged with the task of representing the Mexican government in the United States and promoting immigration and foreign investment in southern Mexico. He incentivized U.S migrant-settlement in Chiapas by offering government subsidies of $\$ 400$ to immigrant families of three or more persons who settled and started a business in Chiapas. He also travelled extensively in the United States in search of foreign capital for the creation of colonization companies; the construction of maritime and terrestrial transport infrastructure, as well as the exploitation of mines and agricultural resources (Molina 2006). He was an astute salesman, who mobilized photographic images 'kodak' to sell investments in Chiapas; he was so successful that rumors began to circulate that he staged many of the photographs he used to obtain investments -ie. introducing lush vegetation to spaces of infertile lands (Molina 2006: 40). As a result of his efforts, José Mora brought many U.S. migrant-settlers to Chiapas, as well as the foreign capital for the construction of the Panamericano and the establishment of the Bank of Chiapas (Molina 2006:40-41).

\section{Settlement and Labour: Interdependent Migrations}

Migrant-settlers from other parts of Mexico, as well as from United States, Europe, Guatemala, and Asia. purchased and colonized public lands along Pacific Coast of Chiapas, particularly in the southernmost region of Chiapas known as the Soconusco. Between 1897 and 1910, the number of property owners in the Soconusco grew from 1,236 to 2,040 (Nolan-Ferrell 2010: 557), and the total population of the Soconusco more than tripled from 20,928 to 75,441 inhabitants between 1892 and 1921 (Nolan-Ferrell 2010: 557-559). 
During the 1890s, the Japanese government took an interest in the opportunities being offered in southern Mexico as a means of opening up a trade route between the two countries. In 1893, a project was proposed to establish a Japanese colony called Enomoto in the state of Chiapas. Three years later, the Japanese ambassador (consul general) travelled to Mexico and purchased 64,000 hectares of land for colonization. The following year, the first boat of Japanese migrants arrived in Puerto Madero and established the municipalities of Acacoyagua and Escuintla. Subsequent arrivals of Japanese settlers also settled in the town of Acapetahua (Choy et al 2014).

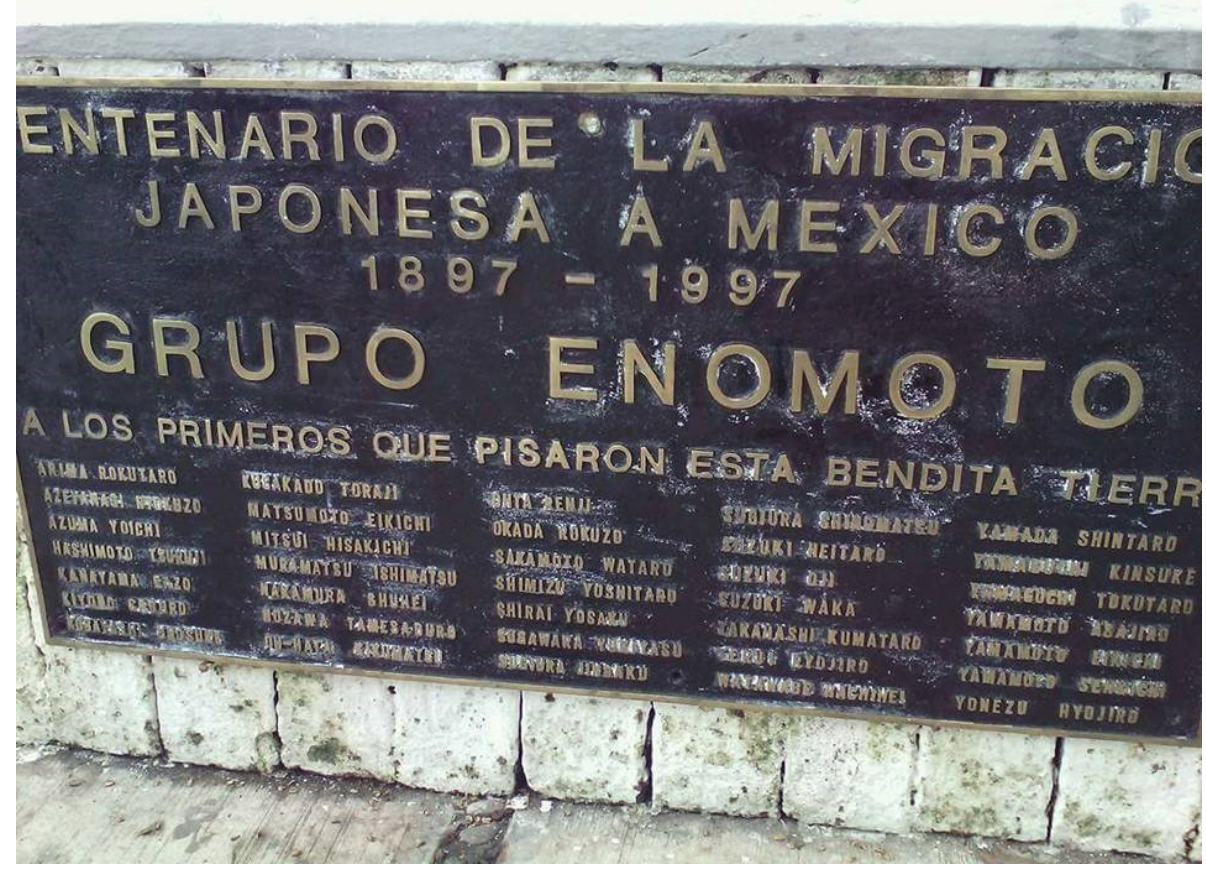

\section{Figure 5 MONUMENT COMMEMORATING SOCONUSCO’S FirSt JAPANESE SETTLEMENT 'ENOMOTO'}

Source: Villanueva, Jorge. 2017. Tapachula a Través del Tiempo. Facebook Page. Retrieved October 10, 2018

(https://www.facebook.com/Por.Jorge.Villanueva/photos/a.258448531254526/322692431496802/?type $=3 \&$ theater $)$. 
North Americans ${ }^{11}$ also arrived in the region during this period. For instance, the Mahken family also left the U.S. in 1882 to establish a plantation in the region for the commercial production of coffee, corn and rubber (Molina 2006: 89-90). The Zacualpa Rubber Plantation (3 km from Acapetahua) was established by North Americas. Most migrant-settlers, however, were Guatemalan landowners of German origin who had arrived in Guatemala during the 1840s and then migrated to Mexico to take advantage of the cheap agricultural land (Washbrook 2007). As was hoped for, the German migrant-settlers brought new technologies for cultivating coffee, thereby opening up the possibility of commercializing, processing and exporting coffee in the region (Choy et al. 2014).

Global demand for coffee grew in the 1870 s and 1880 s, providing incentive for settling in the Soconusco. Almost half of the new landowners (42\%) during this period established haciendas dedicated to the production of coffee (Nolan-Ferrell 2010: 557). Coffee plantations grew from south to north along the Pacific Coast of Chiapas during the 1890s. The first plantations were established in the frontier zone of Unión Juárez, Cachoatán, Tuxtla Chico and Las Chicharras near Tapachula. By the end of the $19^{\text {th }}$ century, they had expanded past the Huehuetán river to the town of Huixtla (Washbrook 2007).

German migrant-settlers were economically dominant in the Soconusco during the early years of colonization (Nolan-Ferrell 2010). Their connections across the Guatemala-Mexico

\footnotetext{
${ }^{11}$ I refer to persons originating from the United States as North Americans (rather than as Americans) because I support the Latin American(ist) perspective which posits that 'American' should refer to any inhabitant of the 'the Americas'. Although Canadians are often considered a part of North America (along with the US and sometimes Mexico -depending on whether definitions are political, geographical or cultural), when looking north from Mexico, North America is almost always a reference to the U.S., and Canada stands separately.
} 
border put pressure on the Díaz government to build a railway that would support the coffee industry's development and connect it to counterparts in Guatemala (Molina 2006: 38). Nevertheless, migrant-settlers on the newly privatized lands along the Pacific coast of Chiapas faced the problem of attracting and retaining a migrant labour force to carry out their exploits, as the local labour supply was concentrated in the highlands of Chiapas. During the colonial period:

... epidemics decimated the local population and with it the cacao production that had made the region prosperous. The villages that survived maintained their hold on cacao orchards into the nineteenth century, and with the arrival of coffee, they began substituting out a new bean for the old pod. Ample land and access to cash income through engagement with commodity markets meant that most villagers were unwilling participants in wage labor. Those willing to sell their labor were already tied to ranches and plantations; workers were in such demand that some hacendados were accused of stealing them from neighboring plantations (Lurtz 2016: 295-296).

Local workers were largely inaccessible to migrant-settlers who owned coffee plantations along the coast. Land routes from the highlands to the coastal plains of the Soconusco were limited, and the 8-day trek by foot was long and arduous for indigenous agricultural workers, who moved seasonally and as a group from one hacienda to another. Furthermore, as newcomers and 'outsiders' in the region, coffee plantation owners did not have the political networks to access this labour supply, which was tightly controlled through longstanding customary and colonial relations of debt peonage between communities of indigenous workers and the highland elites in and around the city of San Cristobal de las Casas (Lurtz 2016; Washbrook 2007).

According to Lurtz (2016), plantation owners responded to the labor scarcity by using their own funds and resources to improve the roads and facilitate the movement of workers 
between the Chiapanecan highlands and the coffee plantations (Lurtz 2016: 313). Owners also drew on their international networks to bring in workers from overseas in the 1890s and early 1900s. In 1891, for instance, 237 men, women, and children from the Gilbert Islands in the South Pacific were brought to the British-owned coffee plantation Finca San Juan las Chicharras. Within a year 180 of them had died from small pox (Lurtz 2016). German plantation owners also offered employment to young migrants newly arriving from their home country, community or family (Choy et al 2014). Sometimes, they would borrow workers from a neighbouring plantation for a few days if the situation became serious (Lurtz 2016).

Then, in 1898, a sharp drop coffee prices which caused many Mexicans to lose their properties to German creditors had consolidated German-migrant's monopoly over the export production of this golden crop. This exacerbated resentment between Mexicans and Germans in the region, leading local officials and competitors to employ strategies to 'charge' migrantsettlers for labour supply in a region where this was scarce and represented a barrier to the expansion of the coffee frontier (Washbrook 2007).

President Díaz and local politicians offered refugees in the Soconusco incentives to stay as workers in the late 1890s (Lurtz 2016: 312). Mam indigenous groups had been fleeing land dispossession and forced labour in Guatemala since the 1870s (Washbrook 2007). The Mexican government welcomed these exiled populations and encouraged their settlement in the Soconusco. In addition, in 1904, German coffee producers reached an agreement with highland elites which opened the doors for Mayan and Chamulan indigenous migrants (from the Chiapanecan highlands) to begin to replace Guatemalans as the main source of seasonal migrant labour on the coffee plantations in the Soconusco. 
These two events helped to relieve some of the pressures that producers faced with regards to the availability of labour. By 1909, two thirds of the seasonal labourers on the coffee plantations of the Soconusco came from the central highlands of Chiapas (en los altos de Chiapas) (Washbrook 2007). By 1910, over 25\% of the total population of Soconusco and neighbouring Motozintla was of Guatemalan origin, and Guatemalans constituted the principal source of permanent and seasonal labour on coffee plantations (Washbrook 2007).

\section{Building a Railway}

Throughout much of the $19^{\text {th }}$ century, Mexico had faced the continuous threat of the territorial annexation of the Soconusco. When Spanish colonialism crumbled in Mexico and Central America, the Soconusco became a contested region with, Guatemala, Mexico and Soconuscan locals all laying claim to the territory at different moments (Romero 1877). An 1882 treaty stabilized the international boundary between Guatemala and Mexico, but, then, in 1894, there was an uprising in the region. The lack of terrestrial routes had slowed the arrival of military forces who were stationed up the Pacific Coast in Juchitán, Oaxaca, causing grave concerns.

Then, in 1898, Finance Minister Limantour presented concerns about the tensions around the idea of continuing railway construction in accordance with capitalists' interests versus broader understandings of the nation's public good. In his recommendations, he suggested government intervention to harmonize development of export sectors in other parts of the country and the expansion of the railway system to areas which had hitherto been excluded from the railway boom. The result of this problematization was the approval of the 1899 Railway General Law (Coatsworth 1981: 45; Lewis 2007; Gorostiza 2010). 
The Railway Law of 1899 marked the beginning of a process by which the state increased its role as a regulator of railway transport. This process, which has come to be known as the Mexicanization of the railways, occurred during the first decade of the twentieth century. During this period, Mexico's federal government bought up controlling interests in the country's railways, eventually placing their administration under the enterprise Ferrocarriles Nacionales de Mexico, established in 1908 (Lewis 2007). By 1910, the Mexican government owned controlling shares in 2/3 of the country's railways, among which was the Panamericano (Coatsworth 1981: 45; FNM 1911). The 1899 General Railway Law also authorized the construction of the 260mile railway, which would run along the Pacific Coast between San Gerónimo (Ixtepec) in Oaxaca and Suchiate, a town located on the Mexico-Guatemala border in Chiapas (Molina 2006).

While the 1899 Railway Law, as well as the FNM annual report cited above, sell the idea that the Mexicanization of the railways was primarily about structuring railway development and administration more evenly and for the broader national (read 'Mexican' good), it was, in the end, those foreign entrepreneurs who owned railway bonds and foreign export-driven enterprises in Mexico who benefitted from these policies, as they "...guaranteed bonded debt of railroad companies", as well as a governmental commitment to the rationalization of service and the maintenance of low tariffs (Coatsworth 1981:176).

Furthermore, it did not sway North American enthusiasm to expand frontier economies south through Panamericanism. In the winter of 1901-02, delegates of the Second International Conference of American States met in Mexico City. ${ }^{12}$ At the time, enough land surveys and

\footnotetext{
12 Davis 1907 offers a detailed report of this conference and of the creation of a Permanent Pan-American Railway Committee.
} 
political legwork had been done to achieve a resolution in favour of building an integrated, transcontinental railway and establishing a permanent Pan-American Railway Commission, which, at the time comprised three representatives from Mexico, Peru and Guatemala, as well as the U.S. capitalist and philanthropist Andrew Carnegie (New York Times 1904; Salvatore 2006).

The following year, in 1903, the Pan-American Railway Commission sent Charles Pepper to travel the length of the route which had been surveyed for the transcontinental railway. On this trip, he was to research and report back to Pan-American Railway Commission on the progress and feasibility of the railway. During this trip, Mr. Pepper visited 14 countries (Mexico, Guatemala, Salvador, Honduras, Nicaragua, Costa Rica, Panama, Ecuador, Brazil, Peru, Bolivia, Chile, Argentina and Uruguay), and he met with representatives in several countries to present the project and to discuss national advantages - principally, internal development and external commerce - of stimulating and prioritizing the construction of links to the existing Pan American trunk line and branches of the Railway (New York Times 1904).

Mr. Pepper's report back to the commission was optimistic about the progress which had been made in the first couple of years since the resolution had passed. With regards to Mexico and Central America, he underlined how Mexico's General Railway Law of 1899 had identified where to connect Central America with the United States and the rest of Mexico. It was this same general railway law which had approved the construction of the 260-mile rail line along the Pacific Coast of southern Mexico between San Gerónimo (Ixtepec), Oaxaca and Suchiate, Chiapas on the Mexico-Guatemala border. This Mexican rail line would be known as $E l$ Ferrocarril Panamericano.

The Ferrocarril Panamericano was built in three sections over a period of 1903-1908. The first section, which ran from San Gerónimo (Ixtepec), Oaxaca to Tonalá, Chiapas, opened 
for commercial and passenger traffic (Molina 2006: 74) on November 1, 1904. A second section between Tonalá and San Antonio was constructed between 1904 and 1906. Finally, the section between San Antonio and Tapachula was completed between 1906 and 1908 (Molina 2006; Gorostiza 2010). The final stretch to Suchiate, and the bridge which would connect Mexico and Guatemala by rail, would not be complete for another few years afterwards.

During the construction of the Panamericano, the vision of intracontinental integration was painted onto the sides of the train cars. The train cars utilized in the construction of the first stretch of the rail line between San Jerónimo (today Ixtepec, Oaxaca) and Tonalá were remodelled in the train yard of Jalisco (Arriaga) and painted "a circle with the flags of Mexico and the U.S. joined together and the words "Pan-American Railway. Route to Panamá." (Ferrocarril Panamericano. Ruta a Panamá) (Molina 2006:69).

Symbols of Pan-Americanism were not only painted on the sides of the train cars; they could also be discerned from the collection of actors who arrived on the scene to assemble the tracks, stations, workshops and other elements of the train-scape. During construction, the railway companies faced the challenges of a limited local labour supply for railway construction and operations, and they had the added challenge of finding workers with suitable skills and technical knowledge. To address these challenges, Japanese and Chinese workers were brought in as railway peons. Chinese labourers who had built sections of the railway in California accompanied the North American investors, and engineers to the Soconusco. Oaxacan labourers who had worked in the construction of the National Railway of Tehuantepec also migrated south for the building of the Pan-American (Molina 2006:79).

As a result, migrants occupied positions of greatest responsibility, including as manager, superintendent, bridge builders, engineers, train conductors and workshop heads (jefes de taller). 
Nevertheless, the distance from the centre of the country and railway boom and the harsh living and working conditions in the Soconusco at turn of the twentieth century made long term settlement unattractive for many of the first migrant railway labourers. Consequently, while migrants began in positions of greater authority, there was generally more occupational upward mobility for local labourers because of the limited pool of qualified workers competing for these positions (Molina 2006: 80).

Migrant-settlers also contributed to the construction of railway infrastructure when it was in their interests to do so. Once the construction of the Panamericano was underway, the Mahken family who owned Rancho Ulapa offered the railway engineers some of their land to build a station. This was an ideal location since it offered steady water and wood supply refuelling the steam engines, and, in exchange, the Mahkens were given rights to freely use the train to travel and to embark cattle for export (Molina 2006: 89). Similarly, in 1908, the North American owners of the Zacualpa Rubber Plantation (3 km from Acapetahua) built the road leading up to the train station, and they financed the building of the railway station and warehouse itself (Molina 2006: 90).

\section{After the Inauguration}

Following the inauguration of the Panamericano, the work of the promotores continued in a slightly different vein. The ecological inventories and transport itineraries were even more straightforward and direct in their solicitation of migrant-settlers. In 1911, for instance, the Traffic and Industrial Departments of the National Railways of Mexico published a 125-page guide in English, entitled Facts and Figures About Mexico and its Great Railway System the National Railways of Mexico. The contents of this book are extraordinarily similar to the contents of Rabasa's 1895 publication on Chiapas, offering an overview of the national 
geography, population, government, climate, agricultural products available for commercial exploitation, and transportation infrastructure, particularly the railway system.

The tone of this 1911 publication, however, is much more direct. The title page actively invites "correspondence relating to industrial opportunities," and it offers the name and contact information of the industrial agent to contact. The book's table of contents highlights subsections, such as "Free Assistance of Industrial Department," "Who Should Settle in Mexico," "Land a Safe and Profitable Investment," and "Opportunities for Gardeners." It directly engages the fact that "...many foreigners have been holding back from investigation of Mexico as a field for investment on account of the difficulties occasioned by the difference of language and their ignorance of the laws and business customs..." (p. 85), and it offers evidence of the many migrant-settlers (referred to as pioneers in this text) who have overcome challenges. Posters, such as the one below, actively petition the arrival of migrant-settlers.

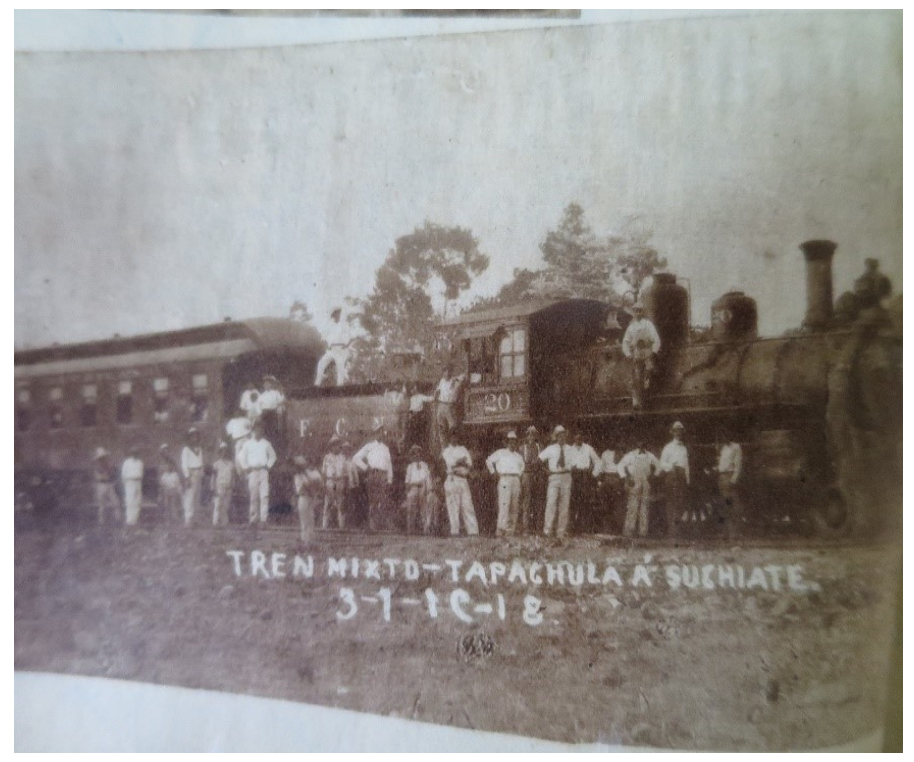

Figure 6- Tapachula-Suchiate Mixed Train. 1912.

Source: Mexico: CEDIF Archives. 
The ecological inventories and the transport itineraries also differ in the 1911 FNM publication. In the sub-section "A Flying Trip over the National Railways," the railway infrastructure becomes a perspective and a tool for navigating Mexico's ecological inventories. The publication takes the reader on a tour on the Panamericano. Moving from north to south, it describes the railroad in sections whose parameters are defined by the presence of railway stations. At each stop, it presents the ecological inventories and transport itineraries which afford opportunities for export agriculture. The textual journey begins:

The introduction to the Pan-American Railroad is at Gamboa, state of Oaxaca. The rainfall at this point is between 20 and 25 inches, and gradually increases to the south, Jalisco having 45 inches, Tonalá about 60, Zaculapa 100 and Tapachula $120 \ldots$ the dry climate in this [first] section should be very healthful and fruit growers familiar with dates, figs, grapes, olives, almonds, coconuts etc will develop it wonderfully (p. 83).

Continuing south along the railway, Jalisco (known today as Arriaga) is noted as a place with an American church and growing colony, as well as its Government road which “...in the dry season carriages, as well as horses and mules, travel over this broad mountain road..." (pp.8384) to Tuxtla Gutiérrez, the capital of Chiapas. Tonalá is highlighted as the place where the reader would find the headquarters and shops of the Pan-American Railroad, as well as a population of 7,000 inhabitants. Here, it says, "The land near the coast is cultivated in corn, rice and sugar-cane; it is generally well-watered by springs. Here too, salt is made from sea water and forms quite an industry" (p. 84). 


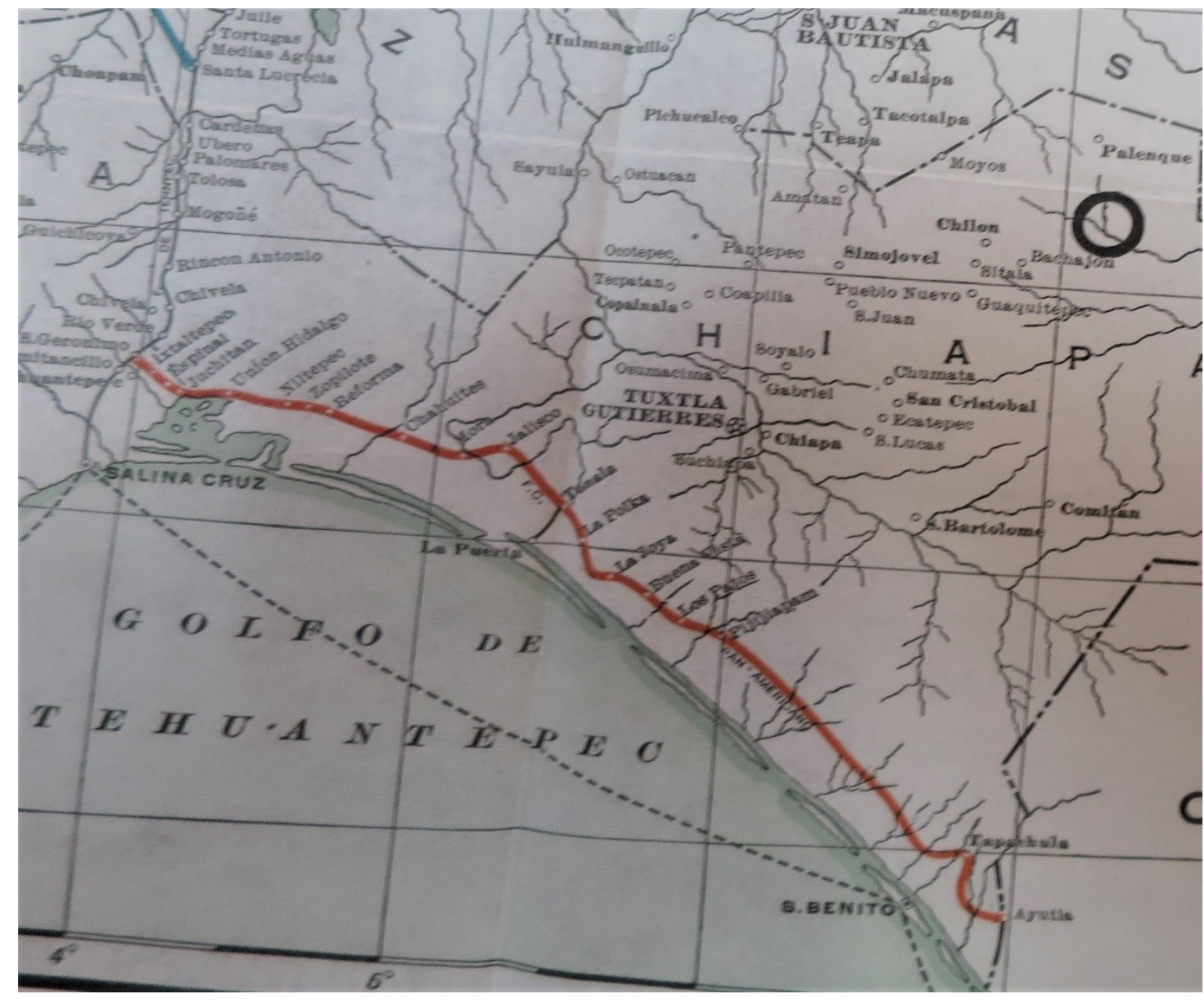

FiguRE 7- MAP OF THE PANAMERICANO AND RIVERS IN 1912

Source: FNM. 1912. Cuarto Informe Anual de los Ferrocarriles Nacionales de México.

Correspondiente al Año social que terminó el 30 de junio de 1912. Edición en español. Mexico:

CEDIF Archive.

South of Tonalá, the guide tells us, is where the market for tropical products begins:

“Oranges, limes, lemons, mangoes, aguacates ${ }^{13}$ (sic), pineapples and bananas are grown in this

\footnotetext{
${ }^{13}$ Avocados
} 
section. Such valuable woods as mahogany, Guanacaste, mora, matabuey, chico zapote ${ }^{14}$ and the like used for cabinet work, wagon making, tool handles and ties are found throughout the jungle" (p. 84). It mentions one or two sawmills being built on the plantations here as a means of profiting from timber. Passing Pijijiapám (sic) ${ }^{15}$, it says, takes us into 'rubber country,' where "occasionally rubber plantations are seen from the train, where the heavy tropical jungles and waving palms bear testimony to the fertility of the soil" (FNM 1911: 84-85). Arriving in Tapachula, we encounter the business centre of the Pan-American Railroad. A city of 18,000 inhabitants at the time, it is noted for the foreign-owned coffee plantations which surround the town. The publication boasts, “...one company with headquarters here operates four rubber plantations and six coffee fincas. ${ }^{16}$ There are many Chinese in this city, part of whom have stores of various kinds, while others are engaged in vegetable raising" (FNM 1911: 85).

Finally, we come to Mariscal, a point where the jungle ends, and the sandy soils begin again. This is the point where railroad travellers are required to disembark and board a ferry to cross the Suchiate river and enter Guatemala. The publication notes existing plans to build a bridge for trains to cross and leave passengers on the other side at a customs house in Ayutla, Guatemala. It is here that the textual journey along the Panamericano comes to an end. As the potential migrant-settlers readers disembark, the publication reminds them:

After a trip over the Pan-American Railroad one is almost intoxicated with the exotic climate, the luxuriant vegetation and the magnificent but undeveloped possibilities of this country. In addition to the purely tropical crops, there is sure and good profit in properly

\footnotetext{
${ }^{14}$ Moras are also known as mulberry trees; the matabuey tree has no English translation; the chicozapote tree is a fruit bearing tree also known as the sapodilla.

15 Today this town as known as Pijijiapán

${ }^{16}$ Plantations
} 
managed plantations devoted to staple products of corn, rice, and live stock. From the point of view of the tourist, hunter and investor, the country is surely worth a visit (FNM 1911: 85)

\section{Concluding Remarks}

“... law, good faith, order, security. Any one can declaim about these things, but I pin my faith to material interests. Only let the material interests once get a firm footing, and they are bound to impose the conditions on which alone they can continue to exist. That's how your money-making is justified here in the face of lawlessness and disorder. It is justified because the security which it demands must be shared with an oppressed people. A better justice will come afterwards. That's your ray of hope," (Conrad [1904] 2007: 63).

This chapter tells the story of how and why the Panamericano was assembled with materials, ideas, and people from around the world. It describes the diverse aims and features of the assemblage and it recounts how knowledge of the land's ecology was mobilized to attract migrants, technology, and capital to build infrastructure. The Panamericano, I argue, was born of efforts to make and consolidate a Mexican state and generate profits. As this chapter suggests, late $19^{\text {th }}$ century state-making was not a haphazard venture in Mexico. It followed a blueprint which held the pursuit of 'material interests' as the best means of pacifying and building emergent modern states in the Americas. In the Americas, material interests were pursued through the development of frontier settlements, railway infrastructure, and natural resource extraction for global export.

In Mexico, the Panamericano was a means of capturing and retaining a territory in the southeast, known as the Soconusco, which, since the dissolution of colonial administration, had vacillated in belonging to Guatemala, Mexico or remaining neutral. The railway captured this 
territory by building the material infrastructure needed to shift the symbolic and material orientation of mobilities away from Old World colonial centres and their Trans-Atlantic routes toward longitudinal routes designed to connect and support the building of Pan-American alliances among the newly-independent republics of the Americas.

Furthermore, the railway's construction served as a means of gathering knowledge of the natural resources of these territories and circulating them in the form of 'ecological inventories' to attract migrant investors and settlers to the region. Migrants from the United States, Guatemala, and as far as Japan were actively solicited to settle and exploit the agricultural land along the Pacific Coast of Chiapas. As such, the settlement of the Soconusco involved many of the same actors who had played a pivotal role in the settlement of other American frontiers, such as the 'Wild West' in the United States: California adventurers; New York railway capitalists; Chinese railway labourers.

This chapter is a counter-memory in that it offers a glimpse of a moment in time when the security of modern states depended on attracting migration. After decades of increased state restrictions on migration, this idea of migration as a solution is somewhat counter-intuitive and important for reminding us that there is not anything inherently menacing about the movement of people.

Secondly, this chapter offers a more complex depiction of the migration. It demonstrates that, by not limiting our studies of migration to one particular type, we can see a principle of interdependence which governs mobilities. In this chapter we see, for instance, how the circulation of ideas of Pan-Americanism stimulated the movement of railway surveyors. The data collected by the railway surveyors was subsequently packaged into 'ecological inventories,' which were then circulated by promotores to attract capital, technology, investors and migrant 
settlers to southern Mexico. The arrival of railway constructors and migrant-settlers stimulated the movement of migrant labourers who either possessed specialized skills or work experience (ie. Chinese railway workers) or derived from migrant-settlers' networks of kinship in their home countries. This domino-like migration effect is rarely captured in studies of the politics of migration, which, as noted in the Introduction, tends to only see a political dance between autonomous states and migrants. 
The old cart still hasn't disappeared in the southeast... But now the rail lines (sic.) of the Central American will signal progress; a path toward the evolution and integration of Mexico (FNM 1955, Author's Translation).

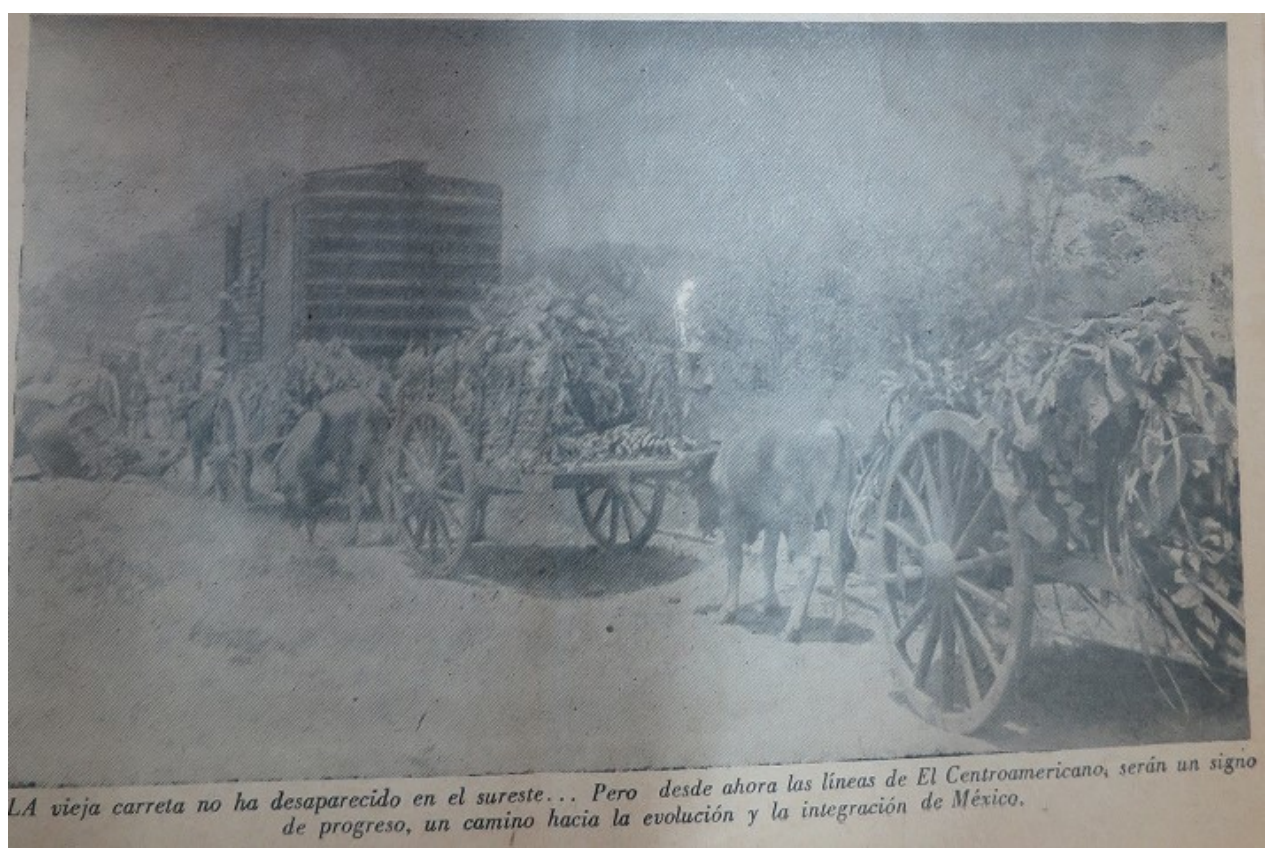

Figure 8- The Old Cart and The Central American Train (La Vieja Carreta y EL CENTROAMERICANO)

Source: FNM. 1955. Revista Ferronales. 1955. (marzo-abril). Tomo XXV. No. 3-4: 9. Mexico: CEDIF Archive.

This chapter counters beastly stories and images by spotlighting the lesser-known everyday railway mobilities of the Pan-American Railway during the 1950s. In this countermemory, we find that ecology is no longer a source of knowledge which can be packaged and circulated to attract migrant-settlers and labourers, which we saw in the previous chapter. 
Instead, ecology becomes a source of friction which challenges modern mobilities and settlements along the Pan-American Railway. The tropical climate and the commercial traditions of the local populations, I argue, pose regular challenges for enacting the modern values and practices embedded in the materiality of the Pan-American Railway. Rains, rivers, chickens, and local populations with traditional systems of intra-regional exchange thwart attempts to separate railway cargo and passengers or humans and nature. Similarly, the railway's ecology consistently frustrates attempts to establish the standardized, predictable timetables necessary to produce the nodes and networks of global connectivity. These interactions spawn representations of 'countermodernity'- Tren de-mora (the berry train/the delayed train); el tren pollero (the chicken train); el tren del amor (the train of love)-which circulate both to communicate and to politicize the railway experience.

In this chapter, we see Mexican state-making shift toward the construction of roads and the production and circulation of cultural inventories to stimulate tourist mobilities. The creation of alternative infrastructure spaces (roads, but also hotels, restaurants, gas stations, and other tourist infrastructure), I argue, offers a second chance to capture territory after the Panamericano fails to offer adequate conditions for state-making in southern Mexico. Road-building, and particularly the inauguration of the Pan-American Highway, I argue, pitted the interests of railway workers and local mobilities against those of the commercial export producers and international tourists, stimulating a mobility politics of retraso which still reverberates today.

\section{Railway Retrasos}

Mobility politics in the early 1950 s centred on a mobilities controversy which can be summarized in a single word: Retraso. In Spanish, the word retraso has two translations which are relevant to this chapter. In the first translation, retraso means delay. In the second translation, 
retraso denotes backwardness or pre/un-modern. For the migrant-settlers and the state-makers who founded the Panamericano, both meanings were an on-going concern during the first half of the twentieth century.

Mastery of time and ecology were of key importance to those who built and depended upon the Panamericano. First, the standardization of time, railway itineraries and rhythms were a necessary part of the integration into Mexico's existing national transportation and communications, as well as a global commodities market. To connect communities and modes of transport, railway traffic needed to flow continuously and in a coordinated manner. Because of the nature of the material infrastructure itself, the fact that a single set of tracks was made available to one single set of vehicles, meant that any delays with one railway service threatened to have a domino effect on the rest of them; it also implied missed opportunities to connect with other vehicles and itineraries which formed part of any given trade or passenger route.

Time was also significant because the products which the Panamericano was charged with transporting had a distinctly limited life cycle. Most of the cargo which travelled along this railroad was agricultural. As such, the rhythm and pace of railway mobilities not only had to line up with the railway and shipping itineraries of the rest of the republic, they also had to work with seasonal cycles of planting and harvesting, rain and dry, and the movements of seasonal agricultural labourers recruited for specific harvests. Any delay in the arrival or departure of a cargo train always threatened to spoil bananas, coffee or other similar agricultural products and cause considerable losses for the producers.

Rains, Rivers and Ants 
From the beginning, the interaction of the Panamericano with the local ecology produced challenges for the region's political and economic integration. The railway managed to connect communities locally, but it failed to connect the region to the country and the world as it had initially intended. Railway infrastructure and ecology challenged the standardization of railway time and itineraries which were pivotal for producing and/or maintaining these connections. On the eve of the Mexican Revolution in 1911, Pollard (1913) ${ }^{17}$ takes a journey on the Panamericano from Tapachula to San Gerónimo (Ixtepec). In optimal conditions, it took 2 full days to travel the full length of the Pan-American Railroad from the Guatemala border to the junction of San Gerónimo (Ixtepec) on the Tehuantepec Railroad. Nevertheless, optimal conditions were a rarity on this railway. In Pollard's description of his journey on the Ferrocarril Panamericano, he makes two observations of enduring importance for understanding mobility politics on the railway in the 1950 s and in the early $2000 \mathrm{~s}$. The first observation related to the already deteriorated state of the railway equipment itself. In his description of the train equipment, Pollard (1913) described it as that which:

... reminds one of the Buffalo Bill shows of Europe: the old-fashioned engine, with its queer funnel and clanging bell, (a genuine 'Baldwin', but of early vintage, finishing its last days in the Tropics); the Indians and the 'rurales ${ }^{18}$,' all variously armed and accoutred; the passengers ablaze with silver-embroidered pistol-holsters and glittering

\footnotetext{
${ }^{17}$ Hugh B.C. Pollard was an English businessman who was sent to Tapachula as an auditor and fee collector for a London-based company that had set up office in Tapachula. His book, A Busy Time in Mexico: An Unconventional Record of a Mexican Incident, offers a personal narration of his railway journey from Tapachula to Mexico City in 1911. Pollard's testimony is significant because it is one of the few descriptions of the early days of travel on the Panamericano. Furthermore, it offers on-the-ground insights of the railway as a key space of political contention leading up to the Mexican Revolution. The book ends with Pollard in the State of Mexico waiting for the opportunity to board a train which will get him to his home-bound ship in the port of Verarcuz without attack or incident.

${ }^{18}$ This was a special police force
} 
brass cartridges, are all reminiscent of the Wild West stories of one's youth. The rolling stock is of the long American type, and the train is usually a 'composite' -passengers and freight mixed- while the end is brought up by a brilliant yellow express waggon for valuable freight and mails (Pollard 1913: 55).

By the time Pollard reaches his connection in San Gerónimo (Ixtepec) and transfers to the Tehuantepec Railway, he comments "The change from the Pan-American system was marked. One can have no idea of the exquisite luxury an ordinary Pullman sleeping-car can afford until one has travelled on a line whose stage of development and whose rolling stock is of the pattern common in Western America forty years ago" (Pollard 1913:61-62).

The second observation which Pollard (1913) makes has to do with the ways in which this already deteriorated material infrastructure was poorly adapted to the landscape and the conditions of the mostly tropical clime along the Pacific Coast Lowlands of Chiapas and Oaxaca. At the turn of the twentieth century, rivers and rain played an important role in shaping of all mobilities in this region. In his description of the Pacific Lowlands of Chiapas, Rabasa (1895) describes the numerous rivers which run along the Pacific Coast Lowlands. He mentions the Suchiate River (which still today serves as the dividing line between Guatemala and México), along with 14 primary rivers which flow from the Sierra toward the Pacific Coast in Chiapas. These include El Cahoacan, Coatan, el Huehuetán, el Huistla (sic), el Despoblado, el Norillero,el Cuapa, el de Pijijiapam (sic), Nancinapa, Los Patos, Ocuilapa, Sanatenco, Tiltepec /Lagartero and las Arenas. According to Rabasa (1895), all these rivers overflowed in the rainy season and nearly ran dry the rest of the year. None was deemed navigable (Rabasa 1895: 7-8).

The railway was constructed over top of these rivers, but it failed to subjugate them. These rivers exercised tremendous influence over the physical, as well as the emotional railway 
experience. Another description from Pollard's 1911 railway journey provides insights as to how:

The journey drones on through the same scenery and the train slows down to cross the little culverts and bridges. Everybody looks anxious. You feel the bridge sink and tremble beneath you, but the train crawls across without its collapsing. The conductor curses the construction engineers, and tells stories of wrecks that have occurred, when the sudden rising of the rivers have swept away the supports from beneath the bridges.... a sudden series of bumps and rockings, finishing with a terrific jolt as the train comes to a standstill, announces that we have run off the line....The engine is off the line, and the tender and first coach are leaning over at a dangerous angle. Underneath you can see the bent rail torn up from the sleepers, but the powdery nature of the wood shows why this has happened. The damp earth and the ants have rotted some six or seven sleepers to such an extent that the engine's weight had forced the rails apart and caused the wreck (Pollard 1913: 56-57).

Pollard recounts that all the passengers and train crew worked together in the blistering heat to jack up the engine, replace the sleepers and re-lay railway track in order to continue with their journey. This particular event put the train three hours behind schedule (Pollard 1913: 58). In order to make up the time lost by the derailment, Pollard recounts, the train driver rushes through the next rest stop and urges the passengers to hurry along. After one rest stop in particular, Pollard notes: "Our driver had been slaking his thirst with copious amounts of beer, so when I heard him declare he would make up time before we got to Tonalá,if only the engine held together, I regretted that my insurance policy did not cover travel overseas" (Pollard 1913: 59). 
The derailment was not the only delay on that 260-mile journey along the Ferrocarril Panamericano, however. Further up the track, Pollard recounts, a construction train informs them that all traffic ahead has been stopped because the political chief of a local, indigenous township had decided to arrest a group of railroad employees for not paying taxes. Pollard and the other passengers were instructed to stay aboard the train while the matter was addressed. He recalled that: "The local police had arrested the whole of the native labour in the construction camp and were now arguing the matter with the white engineers, who were making the telegraph wire red-hot with appeals to headquarters....I heard later that the railwaymen had dealt with the matter personally, and that the Indian town was rather sore" (Pollard 1913:60).

Pollard's description of his journey on the Pan-American Railroad in 1911 is valuable for several reasons. First, it provides a glimpse into the many factors which conspired to defy the establishment of railway time and the possibility effective itineraries. These factors included the second-hand and deteriorated state of the railway equipment which ran on the line from the very beginning, as well as the challenges posed by the ecological features of the landscape - rivers, humidity, insects, and heat. It also offers a glimpse at the violence of dispossessions and taxations which formed part of railway journeys from the very beginning (something which we are told is new on the railway today, which has notably accompanied the track from the start). Finally, we also gain insight into the frustrations and fears of the train conductors tasked with navigating those delicate systems and safeguarding lives. Pollard offers early insights into the politics of railway time and speed, and we begin to see the strategies which train drivers and passengers used to negotiate this context. ${ }^{19}$

\footnotetext{
${ }^{19}$ See Ashmore (2013) and Walters (2015) for works which address how the materiality of a vehicle shapes the passenger experience and the formation of mobile communities.
} 


\section{Rieleros and the Tortuguismo Movement}

The Mexican Revolution (1910-1920) further exacerbated ecological retrasos on the PanAmerican Railway. Following the most intense years of political turmoil (1911-1916), the National Railways of Mexico surveyed its infrastructure, only to find that it had to replace large proportions of its rolling stock and rail lines. In his 1916 report to the Board of Directors, the Executive President of FNM, Don Alberto Pani, argued that the infrastructure of the FNM Constitucionalistas was in a terrible state due to the military campaigns, active sabotage and modifications to the railway infrastructure during the conflict. Furthermore, during this period, he noted, significant resources and energies had also been diverted toward the conflict, leading to the deterioration of the railway equipment due to material shortages and a lack of basic maintenance (FNM 1916). Between 1913 and 1916, FNM estimates that it lost approximately 40 passenger cars, 4,000 cargo cars and 50 locomotives. What wasn't destroyed in the conflict, they estimated, was no longer useful due to deterioration (FNM 1916).

In the 1916 report, a budget and justification for the rehabilitation of FNM Constitucionalistas was presented outlining 4 aspects of the material infrastructure which required attention: The railway lines, bridges, buildings and rolling stock (material rodante). It noted that the (vias) rail tracks were in poor state because there was a shortage of material needed to maintain them. Bandits regularly stole wood needed for the sleepers.

Each of the railway's subdivisions required distinct rehabilitation efforts, depending on the unique impact which the Revolution had on each railway. El Ferrocarril Panamericano which was part of the Southern Division- was less affected by sabotage and banditry than it was by the lack of maintenance needed to combat the deteriorating effects of the climate and geography on the railway infrastructure. Thus, while other subdivisions were faced with 
rebuilding terminals which had been destroyed in conflict, the Panamericano was tasked with replacing bridges which had been weakened or washed out by the rivers and rains, not by insurgents.

Thus, following the period of turmoil, the National Railways of Mexico had to replace large proportions of their rolling stock and rail lines. The estimated cost of rehabilitation of FNM Constitucionalistas in 1916 was \$4,000,000 (FNM 1916: 27). Nevertheless, replacement and basic maintenance of railway equipment was difficult because of Mexico's dependence on the United States for railway technology, and because the Mexican currency was volatile and limited in purchasing power during the conflict (FNM 1916: 22). Furthermore, following the 1929 crash of the markets in the US, Mexico found it increasingly difficult to purchase and import railway equipment (Alegre 2013: 29) ${ }^{20}$.

The deterioration in railway infrastructure was accompanied by a deterioration in working conditions. Railway workers paid a heavy price. According to statistics published by the Ministry of Communications and Public Works in 1933, the annual number of injuries occurring along federally administered railways and tramways in Mexico rose steadily from 3,500 in 1926 to 9,400 in 1930 (SCOP 1933: 117). The majority of the dead and injured were rieleros (railway workers) who worked for Nacionales de México, which, at this time, was the largest of the federal railway concessions and the one charged with administering the Panamericano. In 1931, Nacionales de Mexico had, by far, the highest accident rates in Mexico, accounting for

\footnotetext{
${ }^{20}$ This was partially remedied in the 1930s, when Mexico shifted to an ISI development model, which aimed to reduce national dependency on foreign imports through state-incentives to industrialize. Within this context, in 1944, Mexico became the first and only Latin American country to manufacture its own steam engine. Affectionately nicknamed 'La Fidelita,' this locomotive is still a source of pride and joy for railway workers in Mexico (Alegre 2013: 29).
} 
approximately $75 \%$ of the injuries and $61 \%$ of the deaths on railways (SCOP 1933:118). Of the accidents which occurred that year on the railways of Nacionales de Mexico, railway workers accounted for $93 \%$ of injuries and $32 \%$ of deaths. In contrast, passengers travelling on these railways that same year accounted for less than $1 \%$ of the accidental injuries and deaths (SCOP 1933: 188). ${ }^{21}$ While the majority of worker injuries occurred outside the context of a train in service, there was still significant number of accidents as a result of trains crashing into other trains; derailments; falls and strikes (golpes); run overs (atropellamientos) and accidents occurring in the context of connecting and disconnecting the railway cars (SCOP 1933:118).

Workers staged regular protests over their working conditions, ${ }^{22}$ and, in 1933, the most powerful union in the country was born: the Sindicato de Trabajadores Ferrocarrileros de Mexico (STFRM). President Cárdenas came to power in 1934 and was supportive of industrial unions' demands. He placed the workers in charge of administering the railways in 1936 and he formally expropriated/ nationalized the whole railway system in 1937 (Alegre 2013). The workers inherited tremendous challenges when they took on the railway administration. The railway infrastructure (rails, bridges, rolling equipment) was insufficient in quantity and in disrepair as a result of political conflict and insufficient inflows of capital and equipment. The railway also carried a crippling debt to foreign bond holders (Alegre 2013). In response, the

\footnotetext{
${ }^{21}$ SCOP (1933) estimates that, in 1931, 2870 railway workers were injured and 50 were killed due to railway accidents. That same year, SCOP recorded just 33 injuries and 7 deaths among railway passengers. There were also another 292 people- neither passengers, nor workers - who were killed or injured on these railways (SCOP 1933: 118). My understanding is that some of other incidents can be attributed to suicides, and others to a variety of pedestrian accidents (ie. falling asleep on the tracks after a night out in the cantina). Railways often ran through the centers of towns at this time, and cantinas were notoriously part of the railway neighbourhoods, making these kinds of incidents more commonplace than they would be today.

22 This conflict between workers and railway administration over the root causes of railway accidents and the adjudication of responsibility is a worldwide phenomenon whose history is as long as railway technology itself (López and Segado 2010).
} 
workers hired more workers, raised wages and they attempted to raise freight prices, particularly on mineral exports to the United States. This final point proved contentious, and, in 1940, incoming President Ávila Camacho transferred the railway administration to Ferrocarriles Nacionales de Mexico (FNM) (Alegre 2013: 38-39)

The revolutionary, nationalist stance which the rieleros developed during the Revolution became a "collective disposition" and identity expressed in the written publications, corridos (songs) and testimonies produced during the first half of the twentieth century (Alegre 2013:29). The railway workers were presented as national heroes and the vanguard of modernization in Mexico. During the 1940s and 50s, these representations were mobilized to put pressure on railway workers to increase production despite declining wages and working conditions. Railway engineers were subject to even greater pressure since the responsibility for trains arriving late was placed on the engineer, who the company fined for failing to effectively manage their crew (Alegre 2013: 75). The railway engineer was also tasked with reporting tardy co-workers to the company, a point which increased in political divisiveness when labour actions (such as regularly working overtime hours) began in the 1950s (Alegre 2013:75).

In 1953, an underground movement among railway workers came front and centre. It involved "audacious risk-taking, such as slowing production, sabotaging equipment, and propagandizing at workplaces in broad daylight...” (Alegre 2013: 96). Activists demanded better working conditions and the removal of charros ${ }^{23}$ from directing the union. As Alegre (2013) tells us: 
On August 7, 1953, the union agreed to help the FNM clamp down on workers accused of causing train accidents and delays, even if they were the result of poorly maintained rails and equipment. The accord between the head of the STFRM and the company represented a major concession on behalf of the union, because the workers had been adamantly stressing that faulty equipment, not incompetent workers, caused accidents. As we have seen, workers explained that it was impossible for them to abide by FNM speed regulations without causing delays. Hence, trenistas commonly broke regulations, driving over the speed limit on defective tracks, in order to pull into the station on schedule. This practice resulted in accidents, often fatal to passengers and workers, and always costing thousands of pesos in damaged equipment. Workers continued to insist that the company needed to focus on repairing the equipment, not penalizing workers. Now, more than ever it was clear that the union was in cahoots with the company to discipline the rank and file (Alegre 2013: 97).

The appointment of David Vargas Bravo (a charro) was strongly opposed at this time. In response, during the summer of 1954, railway workers protested their working conditions and the undemocratic state of their union (ie. the charro alliance with FNM administration) by slowing down mobilities on the railway lines in Central and Northern Mexico. This worker campaign came to be known as the tortuguismo movement (tortuga, means turtle in Spanish). As Alegre (2013) explains: “...by dragging their feet at work, they would wreak havoc, causing delays in passenger and freight schedules” (p. 99). Their demands included raised pensions for retirees, particularly of the workers made redundant by diesel train technology; higher pay for drivers or repairers of diesel trains, five-day work weeks and paid expenses during trips (99). 
The tortuguismo movement caused great damages to FNM, the country and to the shippers by immobilizing 50,000 tons of freight and 300 railways cars (Alegre 2013: 99).

The tortuguismo movement culminated in a national railway worker strike in 1959. Because the Panamericano was the only modern form of transportation along the Pacific Coast of southern Mexico (south of Arriaga), if a river washed out a bridge or workers slowed transportation in protest, then commercial agricultural producers lost contracts, crops, and businesses.

\section{Road-Building, Cultural Inventories, and Tourist Mobilities}

With many of Mexico's revolutionary conflicts resolved, the post-revolutionary government of President Elías Calles (1924-30) set about the task of reconstructing transport and communications infrastructure which had deteriorated or been destroyed during the Revolution (Gruel 2017). This interest in reconstruction coincided with the US private sector interest road building as a means of creating new markets for tourism US automobiles south of the border (Gruel 2017; Ficek 2014).

All of this also coincided with two additional events: In 1923, at the V International Conference of American States, the Pan-American Railway Commission proposed the construction of auxiliary roads to support railway infrastructure. The idea was so well received that an agreement was quickly reached to hold a road conference in Buenos Aires in 1925 (Ficek 2016). Among Latin American countries, there was tension around recent US military interventions in the Caribbean and US economic expansionism/ imperialism in this period. Nevertheless, in Mexico, the impulse to promote national integration following the Mexican Revolution was strong, plus the economic benefits that tourism could bring to finance such 
infrastructure were attractive enough to put aside these tensions. For other Latin American countries, it was the acquisition of knowledge and commercial exchange which motivated them to agree to work toward the construction of a continental highway connecting all of the republics of America from the US to Argentina.

In 1925, at the Pan-American Conference, it was agreed that countries throughout the Americas should cooperate to connect and integrate their roadways into a Pan-American Highway system very similar to the Pan-American railway project designed years before (Castañón [1951] 1989; Hoffman 1945; Ficek 2016). The New York Times noted, that, “...one of the greatest undertakings in the history of route-building is the Pan-American Highway. When completed, this artery will have connections reaching from Fairbanks, Alaska to Buenos Aires" (Pierce 1952:44).

Shortly following the conference, Mexico's President Elías Calles created the Comisión Nacional de Caminos in 1925 and began construction on the first section of the Pan-American Highway in Mexico, which was to connect Laredo, Texas and Mexico City. At the road conference, Mexican delegates had rejected U.S. offers to help finance road construction, so it was financed by Calles -with bonds and funds from taxing petroleum- and it was built by Mexican contractors after firing a U.S. company. Central America, on the other hand, accepted the U.S. offer of financing (Gruel 2017; Ficek 2016). Before the inauguration of this northern half of Mexico's Pan-American Highway in 1936, construction began on the southern section, which was to run straight through the interior from Mexico City to the Guatemala border. Construction began on the southern half of Mexico’s Pan-American Highway in 1931 (Castañón [1951] 1989). The southern half would be known nationally as the Cristóbal Colón Highway. It 
consisted of roadways suitable for cars, and it followed the route along the Central Highway, or camino carretera, which was inaugurated in Chiapas in 1896 (Castañón [1951] 1989).

While road construction was under way, actors in Mexico and the US turned their attention to another problem. Mexico had earned a poor reputation in Canada and the US as a result of press coverage of the Revolution. The government would need to work on the image of the country to attract tourists (Gruel 2017). To redeem national and international image, the strategy was to showcase the archaeological and ethnic wonders of 'el pueblo mexicano' in artistic and cultural events (Gruel 2017). The image that Mexico wished to promote was that of a modern country that preserved tradition (Gruel 2017).

Thus, in 1928, Luis Montes de Oca, Alberto Mascareñas, Antonio L. Rodríguez and others began a publicity campaign to promote Mexican culture in the US: They published tourist guides, and, within them, they advertised the new roads. They convinced Emilio Portes Gil to create the National Tourism Commission- which would later become the Department of Tourism. This department would finance the production of a radio program called Mexico Nights, which played music and circulated cultural knowledge of the country in the US (Gruel 2017). Later marketing for tourism shifted with the creation of the Asociacion Mexicana de Automovilismo (AMA), William Harrison Furlong- a member of AMA- was contracted by the Mexican government to promote tourism to Mexico. In the United States, Harrison produced and presented short films on Mexico and Latin America, and he opened AMA offices in California and Arizona. Beginning in 1932, the AMA tourist information office in the US offered would-be tourists maps, guides and the suggestion that they not make any negative political commentary (criticismo beligerante), lest they face anti-gringo sentiments left over from the revolution (Gruel 2017). Tourists were advised to take mosquito protection, food, and equipment to boil water., as 
there was only accommodation available in two cities en route- Monterrey and Mexico City (Gruel 2017).

During this time, travel writers published accounts of their journeys in newspapers, and archaeologists and anthropologists were actively circulating ethnographies and images of pyramids (see Laughlin 1939). For instance, in 1945, Hoffman (1945) detailed the first trip on the Cristobal Colon highway by car. It is an inventory of images designed to encourage the tourist to visit by car. Prior to inauguration, on May 5, 1950, newspapers in the United States announced that the:

Inauguration of the new Central and Cristóbal Colón Highways with an automobile race early in May from the Río Grande to the Guatemala border will advertise the greater motoring pleasure being made available in this country. Antonio Cornejo, general manager of the race, began accepting entries for it Feb. 1. Any five-seat, closed, factorymodel passenger car, regardless of make or year, can enter the race from Ciudad Juárez on the Texas border to Ocotal fronting Guatemala a distance of 2,178 miles. The five-day race will start on May 5 and the car making the best speed will win the first prize of 150,000 pesos or $\$ 17,341$. Second prize will be 100,000 pesos, or $\$ 11,560$ and third prize will be 50,000 pesos or $\$ 5,780$ (Carney 1950: AS15).

The highway raises the stakes in the existing politics of tortuguismo, which pitted the interests of local mobilities against those of the commercial export producers and international tourist mobilities. The highway was routed through the Central Highlands of Chiapas. As such, Pacific Coast settlements which lay south of Arriaga -particularly the region of the Soconuscowere not able to access the highway. 
Secondly, the highway introduced new mobilities to the Panamericano by feeding North American tourists through Arriaga, creating a demand for a different sort of railway infrastructure than that which was used every day by locals. This is because, in 1955, the highway had been completed except for small sections across mountainous terrain in Guatemala, Costa Rica, Ecuador, and Darien, the region encompassing the Panama-Colombia borderlands (Ficek 2014: 50). This fact is important because tourist guides and maps, such as the one below, gave instructions for motorists to transport their cars through southern Mexico by using the Panamericano (see arrow pointing to Tapachula in Figure 9 on page 92). Tourist mobilities demanded modifications to railway itineraries and equipment. They demanded fewer stops, greater speeds, equipment to upload and offload of vehicles, proper passenger cars, as well as a real connection at the Guatemala border, which existed on paper but not in reality. In February 1956, a letter was sent from the Lion's Club in Cd. Hidalgo, Chiapas complaining about the lack of railway infrastructure between Tapachula and Guatemala. The letter outlines how, although tourists could buy tickets to Guatemala via the Panamericano- particularly after the inauguration of the Centroamericano passenger service- there was not a station or a working track available to transport them. Passengers, the letter-writer complained, were regularly left to figure out how to travel the $50 \mathrm{~km}$ from Tapachula to the border, particularly when the road was often not vehicle worthy (AGN. Adolfo Ruiz Cortines Archive / 106611/ Caja 1124; Folder 609/61). 


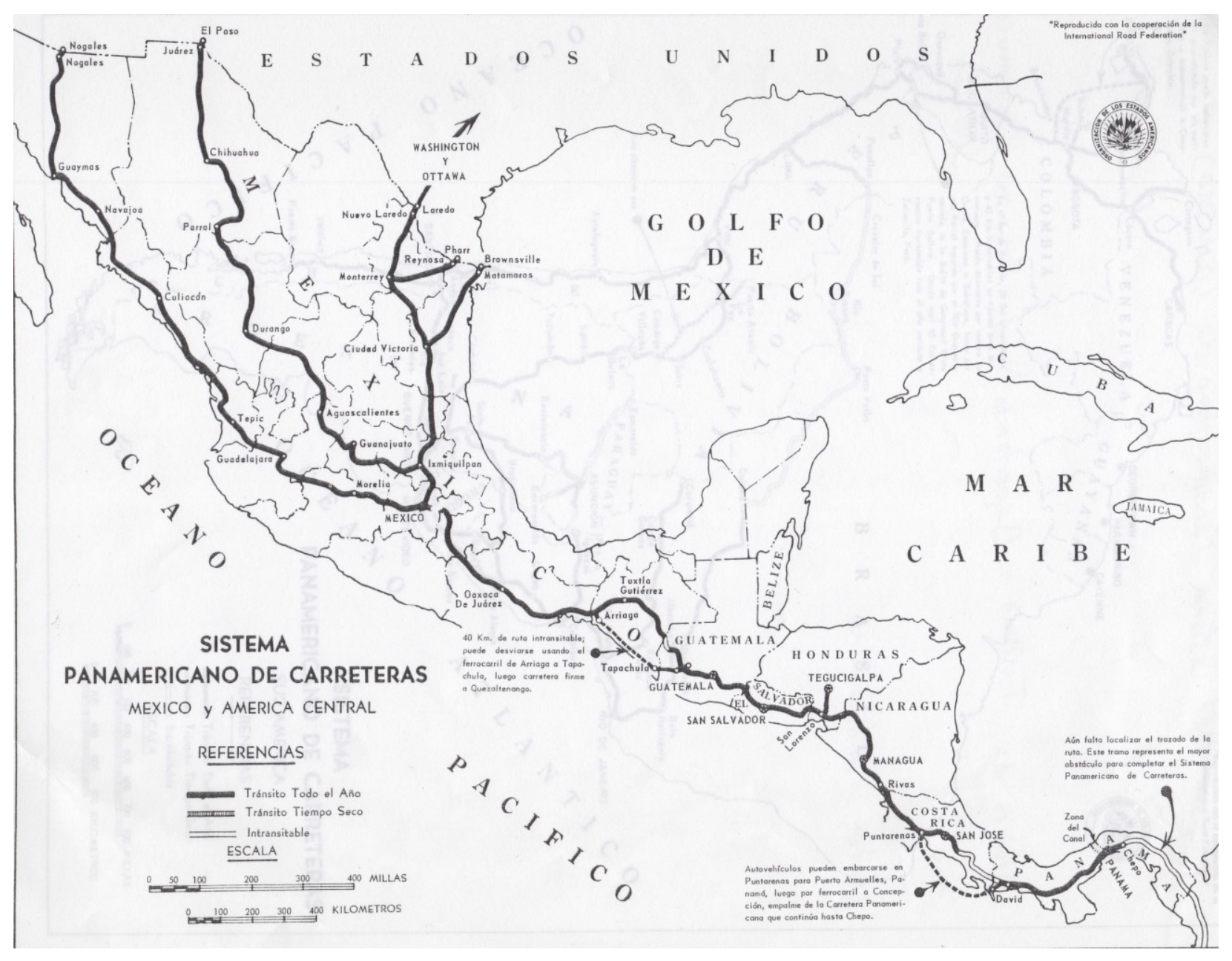

Figure 9- System of PANAmerican Highways in MeXico And CEnTRAL America (1955) 24

Source: Ficek, Rosa Elena. 2014. "The Pan American Highway: An Ethnography of Latin American

Integration.” Ph.D. dissertation, Department of Anthropology, University of California Santa Cruz. Page

46, Image adapted from Columbus Memorial Library, Organization of American States, Washington,

DC, Vertical File, 'Pan American Highway.'

\footnotetext{
${ }^{24}$ The caption and arrow which point to the dotted lines between Arriaga and Tapachula on the map offer instructions for driver's wishing to travel south: " $40 \mathrm{~km}$ of unpassable [highway] route can be navigated by using the railway from Arriaga and Tapachula and then the paved highway to Quetzaltenango" (author's translation).
} 
Third, the Pan-American Highway introduced automobile and bus mobilities which began to compete with the railway mobilities in the region. Roadways had the advantages of speed and flexibility- namely individual control over mobilities because the vehicles and infrastructure were not fused into one machine ensemble (Schivelbusch [1977] 2014) and monopolized by single operators. As we will see in the next section, the lack of roads in the Soconusco and the railway worker actions at the time threatened commercial agriculture. Commercial agricultural producers petitioned repeatedly for faster passenger trains and roadway access to the Panamerican Highway via the Pacific Coast.

Finally, the Pan-American Highway offered a second chance at infrastructural penetration of southern Mexico and gaining a monopoly on the means of movement after the railway infrastructure was captured by the Mexican Revolution. The Panamericano made the Pan-American Highway imaginable (Ficek 2016). But more than that: It gave planners, investors, politicians, and engineers a previous lesson in what to do and what not to do when building an infrastructure state in Mexico.

\section{Letters and Labour}

With the inauguration of the Cristobal Colon Highway in 1950 and increasing interest in capturing capital attached to tourist mobilities which were unleashed with the advent of automobility in the United States and the Pan-American Highway, the Panamericano starts to be problematized for its failure to keep railway time, itinerary and connections. In the press, the railway was referred to as 'El Tren Morado,' or 'El Tren de Mora,' a play on words that made reference to the regular delays (demoras) in service which formed part of the railway passenger's experience at that time, as well as the fruit which the trains transported (mora, meaning berry) (See, for instance, Pérez 1955). 
Agricultural production for export in the Soconusco required large tracts of land, a flexible and steady supply of workers, and reliable transportation infrastructure. As mentioned earlier in the dissertation, the development of coffee plantations was entangled with the construction of the Panamericano. At the end of the $19^{\text {th }}$ century, much of the land which was privatized and purchased along the Pacific Coast of Chiapas was dedicated to the production and export of coffee. Workers on the plantations were primarily from Guatemala or the Central Highlands of Chiapas (particularly the municipality of San Juan Chamula), and they engaged in seasonal circular migrations (Interview 15; Washbrook 2007) ${ }^{25}$. These migrants did not arrive in the Soconusco by train, but rather on foot or by other means, traveling along the carreteras which connected the highlands to the Pacific Coast.

This changed during the 1950s when the entire Pacific Lowland Coast of Central America and the Soconusco region of southern Chiapas underwent what was called the cotton revolution (Parsons 1965). It is estimated that, between 1950 and 1963-4, this entire coastal region went from producing less than 100 bales of cotton per year to more than one million, and that, collectively, this relatively limited region was producing approximately two percent of the world's cotton (Parsons 1965:151). The Soconusco region of Chiapas produced 100,000 bales of cotton on 70,000 acres of land in 1963-64 (Parsons 1965). During this time, Tapachula grew dependent on the agricultural labour of workers from the neighbouring state of Oaxaca, and the first railway migrations emerged. As one local recalls:

\footnotetext{
${ }^{25}$ Nevertheless, there is evidence of seasonal labour migrations from Oaxaca. According to Lynn Stephen, in the 1930s, men from the village of San Bartolomé Quialana (Oaxaca) migrated seasonally to Tapachula for the coffee and sugarcane harvests, and later, for cotton. Prior to the construction of the Pan-American highway, their migrations involved walking in small groups for up to twenty days to reach Tapachula (Stephen 2007: 104). In the mid-1960s, contractors from the northern states of Sonora and Sinaloa began to recruit workers from this same village, causing a labour shortage in Tapachula (Stephen 2007: 106).
} 
... with the boom in cotton production in the 1950s, Tapachula saw the first important labour migrations. These comprised people from the Oaxacan valley. They would arrive in the town of Juchitán and they would take the train there to come here. Then, when the train arrived, main street here in Tapachula would fill with indigenous people. On every street they would sit with their food- their chuaque, their large tortilla, chile etc. and, right there, they would eat as a group. It wasn't one person; it was the whole street! Oh, and another thing, they didn't come in passenger cars, but rather as cargo. Whole families travelled to Tapachula in cars designated for livestock, with the bars and everything...They paid for a ticket, but they were discriminated against. This was of course the product of an arrangement made between those who managed labour recruitment and the railway workers who didn't treat them like human beings, but rather as pieces of cargo (Interview 15, author's translation).

Seasonal labour migrations were critical to the livelihoods of many of the migrant-settlers engaged in agricultural production along the Pacific Coast of southern Mexico. Beginning in the 1940s, road-building and the U.S. Bracero Program generated new opportunities for seasonal labour migrants to travel farther afield. These two factors compounded the problem of labour scarcity which, as we saw in the chapter one, was a significant challenge for the settlement of the Soconusco. ${ }^{26}$

\footnotetext{
${ }^{26}$ When Oaxacans stopped their seasonal migration, this generated great difficulty for the finqueros in Tapachula. In 1968, for instance, migrant labourers were so scarce that headlines in the region's newspaper Diario del Sur carried headlines that the cotton harvest for that season was in danger due to a lack of workers. In the article, commercial actors publicly argued that the Guatemalan border should be opened to let workers come to harvest cotton in Tapachula because Oaxacans from la sierra no longer made the seasonal trip and preferred to travel to the Isthmus than go all the way to Tapachula for work (El Diario del Sur, January 19, 1968, front page).
} 
In the early 1950s, migrant settlers engaged in commercial agriculture expressed their concern that they could be cut off from the rest of the country and the world as a result of their complete dependence on the railway. In letters they wrote to diverse politicians, these actors framed their preoccupation as a question of life and death and petitioned authorities to rehabilitate the Pan-American Railway and to diversify transport infrastructure along the Pacific Coast in the name of economic development. Their argument was two-fold: 1.) We need a railway that is reliable, and 2.) We need an alternative to the railway so that we can reduce our dependence on this one form of transport. These concerns can be seen in a series of letters and actions at this time.

On January 16, 1953, for instance, the Chambers of Commerce in Tapachula, Huixtla, Tonalá and Arriaga, as well as the Soconusco Association of Coffee Growers (Asociación de Caficultores de Soconusco) and the Municipality of Tapachula, sent a letter to Mexico's President Ruíz Cortines asking for the rehabilitation of the Panamericano and the construction of the Arriaga-Tapachula highway. The letter is divided into two sections, each arguing for one of the two aforementioned petitions. The first, and longest section, outlines 10 examples "the disastrous conditions" in which the Panamericano operated at the time. It said:

One- The cargo and passenger trains constantly arrive with 24, 48 and even 72-hour delays. Two- Derailments are almost a daily occurrence. Three- The boxcars are in deplorable state, with the rooves, walls and flooring perforated with holes, leading to considerable loss of cargo for those who use it. Four-The windows of the passenger cars run without window panes, curtains or blinds. Five- Sanitary (washroom)services are non-existent. Six- The seats are completely destroyed, the springs broken, making them impossible to be used. Seven- For some years now, it has been impossible to use the 
Pullman cars between Tapachula and Ixtepec because these are so heavy, and the railway lines cannot handle them. Eight- The necessary passenger transfers in Ixtepec and Veracruz cannot be made as scheduled because of the delays in service, forcing passengers to wait in stations for up to 24 hours in order to catch their connections. Nine. - Train personnel show a lack of discipline and, using the poor state of the railway infrastructure as an excuse, they deliberately conduct their labours with noteworthy indifference in order to be able to demand overtime pay. Ten-The Agents and Assistants of Express offer users packing services- on their own initiative- they then remove merchandise and replace it with waste, packing the packages again without signs of tampering, thereby leaving users without means to make their complaints (AGN. Adolfo Ruiz Cortines Archive/ 106141/ Caja 0658; Folders 512.52-513/23. Document 9590. Pp. 1-3; author's translation).

The letter then locates these deficiencies within a broader regional and international context by arguing the following:

This line of communication is conceived of as the main commercial transportation service for commerce and for Central American tourism; given its terrible state, it [the railway] cannot operate as efficiently as it should and invites crude, but well justified criticisms, from tourist groups who risk using this transportation service. If this problem is not attacked with the urgency that it deserves, with the arrival of the rainy season, our region risks becoming cut off [from the rest of the country] (incommunicada), provoking great losses and injuries (ibid. Document 9590. P 3; author's translation).

After detailing the material insufficiencies, the letters conclude that: "It is urgent that an integral rehabilitation of the Panamericano be conducted if you do not wish the state of Chiapas 
to suffer an economic collapse of catastrophic consequences, which we believe should be avoided at any cost" (Ibid. Document 9590. p.3; author's translation).

The second section of the letter lobbies for the construction of a highway between Tapachula and Arriaga to connect the towns of Tapachula, Huixtla, Acapetahua, Mapastepec, Pijijiapa (sic.), and Tonalá amongst themselves, but more importantly to the already constructed sections of the Panamerican Highway. This stretch, they argue, would complete the missing gap/link of intra-continental road transport within Mexico, between Tepanatepec, Oax. and the Guatemala-Mexico border. North and South of these points the Panamerican Highway had been built (NOTE: but, really, this stretch was already covered by the railway, so it would bring in an alternative form of transport to compete with the railway) (AGN- Adolfo Ruiz Cortines/ 106141/ Caja/Box 0658; Folder 512.52-513/23, Document 9590). This letter was one of a series of letters and actions which a network of commercial actors put together in a national lobby for improved infrastructure on the Pacific Coast of Chiapas (AGN- Adolfo Ruiz Cortines/ 106141/ Caja/Box 0658; Folder 512.52-513/23).

In addition to letter writing, stakeholders in Soconusco also organized an Automobile Caravan in October 1953, which marched to the capital in protest over the transportation and communications problems in Chiapas. It was a last-ditch attempt to have their concerns heard with regards to the poor state of the Panamericano (as sole source of transport). In this letter, they say that much of anarchy and disrepair began with the removal of Superintendent Don Pedro de León Palacios from leadership. ${ }^{27}$

\footnotetext{
${ }^{27}$ This is el charro, and those involved with his removal were up the coast in Matías Romero.
} 
Two years later, on March 2, 1955, the Chamber of Commerce in Tapachula sent another letter to President Ruiz Cortines complaining once again about the Panamericano. The authors claim that it is in a state of abandonment and indiscipline with broken equipment. They demand that the president order the railway's rehabilitation given its utmost importance for the transport and communications in this state. The letter mentions that, for years, the authors had been asking for access routes to the Panamerican Highway. The March 2, 1955 letter to President Ruíz Cortines from the Chamber of Commerce in Tapachula (H. Cámara Nacional de Comercio de Tapachula) and signed by Humberto Zapata F. (Presidente) y Cármen Domínguez D.

(Secretario). Once again, the letter described the disrepair of the Panamericano at that time, arguing that the "prevailing situation in this corner of Chiapas is also that of the rest of Mexico" (Archival General de la Nación. Adolfo Ruiz Cortines Archive/ 106141/ Caja 0658; Folders 512.52-513/23. Document 8289, p. 2, author's translation):

The few and old machines which drive the cargo and passenger trains die almost daily and there are no quick ways to repair these in the mechanical workshops (talleres mecánicos). Consequently, there is little hope for the delivery of the 5,000 tons of cargo, which has already been paid for by merchants in Tapachula and whose delay resulted bank interest fees. The train cars which have been assigned to this city take up to two months to make the journey; coffee exporters who face delays in getting their product to the ports of Coatzacoalcos, Ver. or Salina Cruz, Oax., are impacted when their coffee does not reach the ships on time and their sales contracts are cancelled by foreign buyers. Construction sites are frequently left paralyzed for lack of cement, rebar, etc , because they do not receive these materials. Flour and other basic staples are often scarce because of the excessive railway delays. The equipment for the passenger trains in this region are 
the Company's garbage, and the trains arrive with up to 24-hour delays. Over the last few days, we are missing a railcar mover (máquina de patio) to move train cars (con escapes de la via) so that they can be unloaded. Thus, they are being moved with crow bars and by pushing them with human force (p.2 of Document 8289, AGN. Adolfo Ruiz Cortines/ 106141/ Caja 0658; Folders 512.52-513/23; author's translation).

The letter then goes on to argue that the rehabilitation of the Railway would bring great economic benefits through trade and tourism with Central America: "The Central American Republic are an excellent market for merchandise produced in this country. Nevertheless, in order to grow Industry, tourism and trade, with the sister Republics of Central America, it is necessary that Tapachula has transportation routes (vías de comuncación) which facilitate the rapid transport of tourists and merchandise ${ }^{28 ”}$ (p.2 of Correograma 8289, AGN. Adolfo Ruiz Cortines/ 106141/ Caja 0658; Folders 512.52-513/23; author's translation). These same actors pressured the President to rehabilitate the railway through the media. There were open letters published in the newspapers (see, for instance, El Sol de Soconusco, 12 de marzo 1955).

Love Affairs, Birds and La Bayunca

\footnotetext{
${ }^{28} \mathrm{It}$ is curious to note the fact that these letters always express concern for movement of tourists -and not labourin the region. During my field research, I asked repeatedly interviewees about tourists on the Panamericano, and I was told by more than one person that there weren't any. I was told that Central American tourists travelled by air or road, but not by rail. The reason for this discrepancy, I believe, may lie in the fact that the construction of transport infrastructure during this period was openly connected to the development of markets for tourism and not for the export agriculture and other natural resources (as was the case of railway construction). Given this context, we could understand the agricultural producers' reference to tourism as a strategic framing of their petitions for railway rehabilitation and highway construction. A second hypothesis worth further research is that 'tourism' for residents of the Soconusco was equated with any short-term stay of a 'foreigner' which involved purchases. Review of newspapers at this time often refer to Central Americans who visited the Soconusco for cross-border shopping (compras) as tourists. This, of course, is very different from the type of tourism which the Mexican government was trying to establish through cultural inventories and road-building.
} 
"A clamoring population surrounded the train at every stop, trying to sell tacos, tortillas, chicken breasts in lettuce dripping with red chile sauce, cheese, ices, coffee, coconut milk, fruits, and fly-blown sweets to the five ultimate customers on the train"

(Laughlin 1939).

The letters which the Chambers of Commerce repeatedly wrote and published offered the impression that the railway was, in fact, the sole lifeline for the region, and that, without it, people would starve since the imports would not arrive on time and the exports would not bring in the capital needed to purchase these other basic elements for survival. Nevertheless, while these voices of complaint were loudly and proudly protesting on paper and pavement (the 1953 auto-thon), the everyday practices of local railway passengers challenged these very claims.

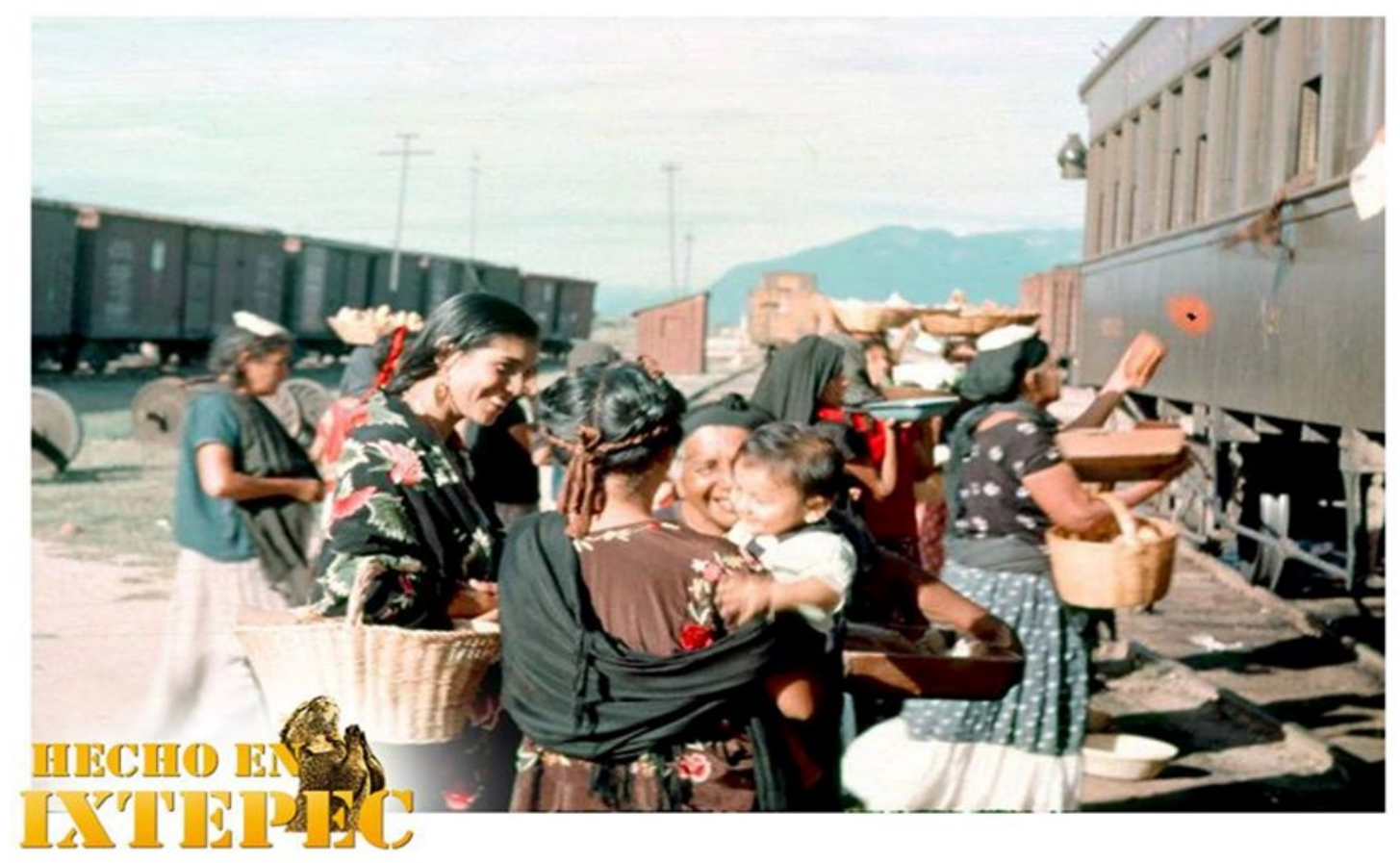

Figure 10- LA BAYUNCA IN IXTEPEC, OAXACA 
Source: 'Ixtepec Oaxaca' (public). Facebook page. Retrieved Feb. 18, 2017

(https://www.facebook.com/ciudadixtepec/photos/a.681073948675130.1073741827.681073792008479/

$$
\text { 997532150362640/?type=3\&theater). }
$$

Passengers who remember the mixed and passenger trains of the Panamericano tell tales of railway travel that will fill your senses with the unique smells, tastes, sounds and sights of southeastern Chiapas. This is because la bayunca was central part of the local economy and the trainscape of the Pan-American Railway for much of the twentieth century. La bayunca was practiced (mostly) by women known as bayunqueras who moved up and down the coast, selling their agricultural goods on and around the railway. Las bayunqueras carried many types of fish; tamales; corn on the cob, and all sorts of fresh fruit water (aguas frescas). They also frequently carried live birds onto the passenger cars of the mixed cargo-passenger trains which ran between the towns of Ixtepec and Tapachula on the Panamericano. This practice earned the mixed train services no. 169 and 170 the nickname of 'el tren pollero ${ }^{29}$ ', or the chicken train, because live poultry (aves de corral) was one of the many products which female comerciantes (vendors) would bring on board (Sibaja 2002). One local recalled:

Those local bayuncas were fundamental ... The food!... which was -hijole-another world! People knew where the woman who sold fish got on the train - the one who sold fresh fish, recently pulled from the sea or the tidepools, and served hot. There were enormous handmade tortillas, still warm and salsa...so, for example, anyone who wanted

\footnotetext{
${ }^{29}$ In Spanish, unauthorized migrants are often referred to as 'pollos' (chickens) and migrant smugglers are referred to as 'polleros' (chicken hearders). In the early 1990s, at least one media report tried, unsuccessfully, to repurpose 'el tren pollero' (the chicken train) for the emerging field of migration politics by drawing connections between the nickname given to the mixed train service and the practice of migrant smuggling, as a person who smuggles migrants is referred to as a pollero in popular slang. This attempted translation didn't stick despite its obvious potential.
} 
mojarras would go at seven in the morning, and it would be packed as people tried to be the first to get the food as it came on board. Obviously, there were empanadas and fried and roasted chicken, beans, rice, hard boiled eggs. Every station had its character or speciality...it was known who got on the train and where in order to purchase what they were selling. And, in the bayunca, there was everything: deer meat, stork, las chachalacas (a type of bird). In sum, the food was fundamental...and the street calls of the bayunqueras as well. How did they go again? 'Café! ¡Café con leche! (Interview 15).

During the 1940s and 1950s, passengers occupied the railway primarily as a means of transport to and from the major commercial centres in the region: Tapachula, Tonalá and Arriaga (Interview 15). The most important movement of people consisted of those going to Tapachula to shop for the day. These were daily intra-regional commutes, which dominated the trainscape (Interview 15). Passengers travelled primarily on mixed cargo-passenger trains, which allowed for transport of personal or small-scale cargo and multiple stops. As one local historian recalls:

The most important passenger terminal was Tapachula. In the beginning, the railway was managed so that people in the region could connect or would have access to centres of consumption, such as Tapachula., and later Tonalá, and obviously Arriaga, which was of great importance during its time (Interview 15).

Passengers engaged in local tourism and love affairs aboard the Pan-American Railway. The mixed train service between Mapastepec and Tapachula, for instance, came to be known as 'the Train of Love' (el tren del amor) because it was a favourite -and arguably the only- place for lovers to meet without risking discovery by parents, spouses or curious neighbours in their hometowns (Interview 14; Sibaja 2002). Among locals, it was said that, the sounds and sensations of travel on this train formed the soundtrack for many a railway lover at the time and 
they were represented accordingly. When this train reached its highest speed, it expressed its lovers' mission (misión amorosa) through the pumping of its cylinders, the blowing whistle and escaping steam (Sibaja 2002).

The railway was a source of vitality for the bayunqueras, the lovers, and local shoppers. It was a space of exchange which thrived upon the many stops, frictions, and retrasos produced by the interactions of ecology and the railway's material infrastructure. Furthermore, for las bayunqueras, the importance of the mixed cargo-passenger train service cannot be understated. Commercial chambers' lobbies for a suppression of stops and increased railway speeds were a direct threat to the bayunca enterprise.

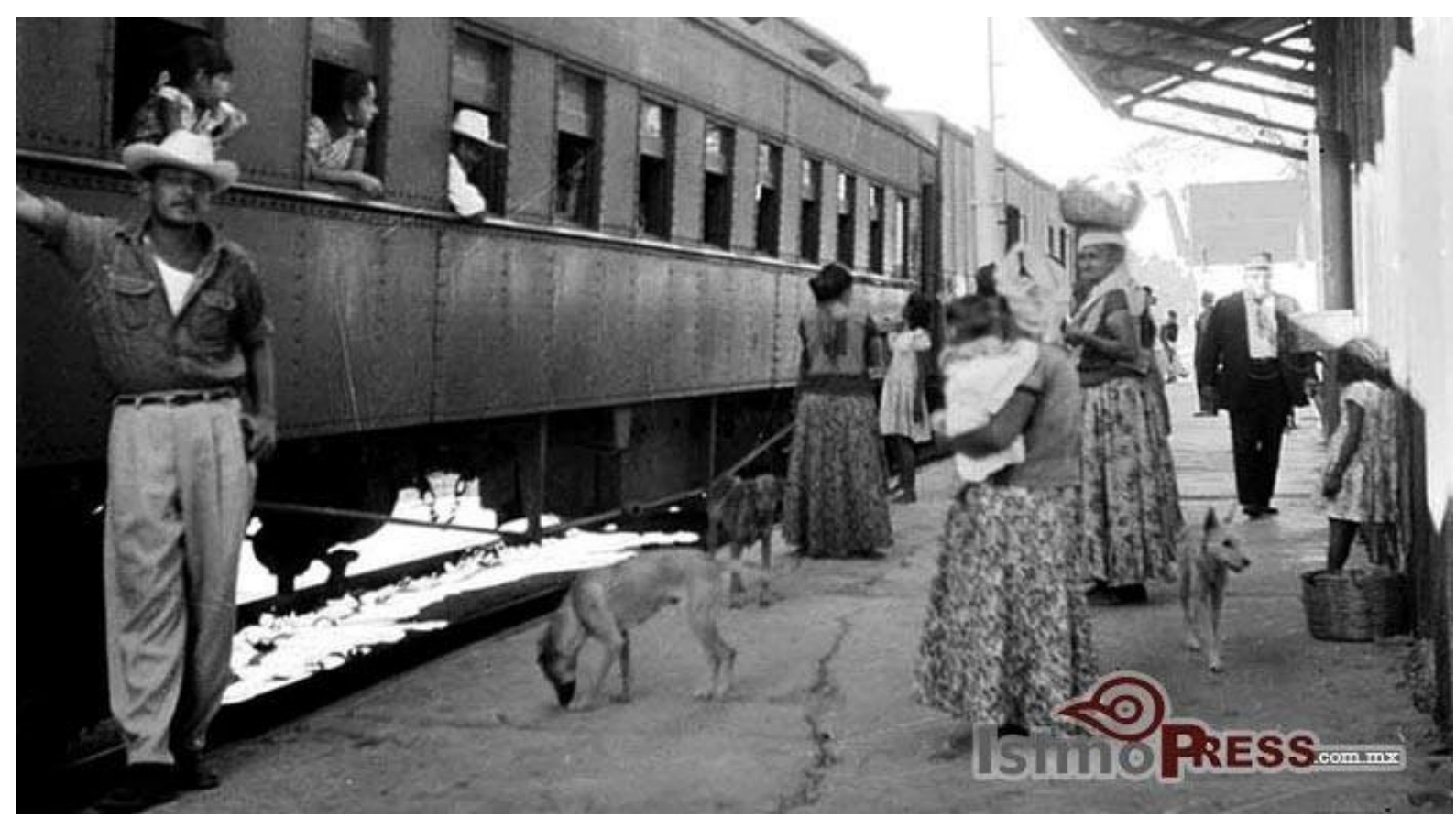

Figure 11- LA BAYUNCA IN THE IXTEPEC TRAIN STATION

Source: 'Ixtepec Oaxaca' (public). Facebook page. Retrieved Sept. 30, 2017

(https://www.facebook.com/ciudadixtepec/photos/a.690581441057714.1073741828.681073792008479/ $\underline{885944014854788 / \text { type }=3 \& \text { theater }) .}$ 
In July 1954, for instance, plans to eliminate the daily mixed train service (mixto) between Mapastepec and Tapachula were announced. Right away, concerns were raised about the terrible consequences of this decision for local passengers along this route. The press published concerns regarding how the cancellation of this service would affect agricultural and commercial passengers who regularly conducted day trips between the two towns. Elimination of the service was to restrict the mixed train service to an Ixtepec-Tapachula route only, and this modification would make it impossible to return to Tapachula on the same day, leaving passengers to lose a day/ night in travel. At the time, there was a high demand for this mixed and regular passenger service along the coast. People were often left behind at stations for lack of passenger cars and while many other people travelled "seriously endangering their lives by hanging on to the sides of the train (colgados de los estribos del tren con grave peligro para sus vidas)" (El Diario del Sur 1954: 4).

\section{Concluding Remarks}




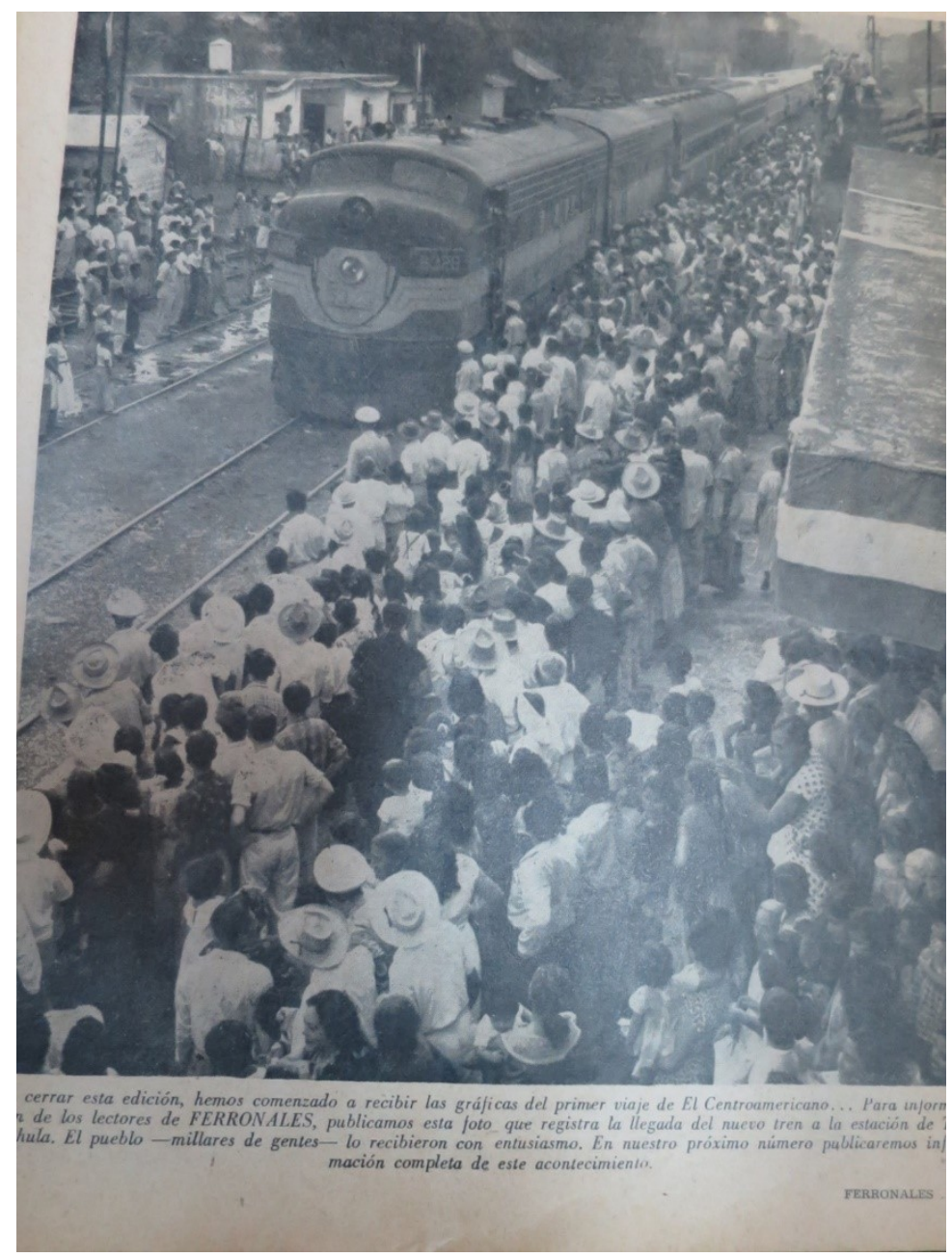

Figure 12- The CEnTRAL AmERICAN ARrives in TAPACHUla on InAUgural Journey (1955) Source: FNM. 1955. Ferronales. Tomo XXV. No. 3-4. marzo- abril 1955. Mexico: CEDIF Archives.

On April 19, 1955, the front-page headline of the newspaper Diario del Sur announced the inauguration of a new train service on the Panamericano. This service would be called $E l$ Centroamericano (E1 Diario del Sur 1955). Beginning May 1, 1955, the newspaper announced, this service was to provide a daily, direct and rapid railway services for passengers and express packages travelling between Veracruz and Tapachula. Costing the FNM approximately twenty million pesos, El Centroamericano was to comprise eight diesel units, five dining cars, eight 
Pullman cars, eighteen second-class, ten first-class passenger cars, and ten express post cars.

Some fifty-one units had been designated to El Centroamericano, making it possible to run up to five separate trains (El Diario del Sur 1955). The direct service was to run daily and would cover the 880-kilometre distance between Veracruz and the Guatemala border in just twenty-six hours, saving passengers approximately fifteen hours in travel time. This was done by switching from steam to diesel engines and by suppressing ninety-one stops; tickets for railway passage remained the same. (El Diario del Sur 1955; FNM 1955).

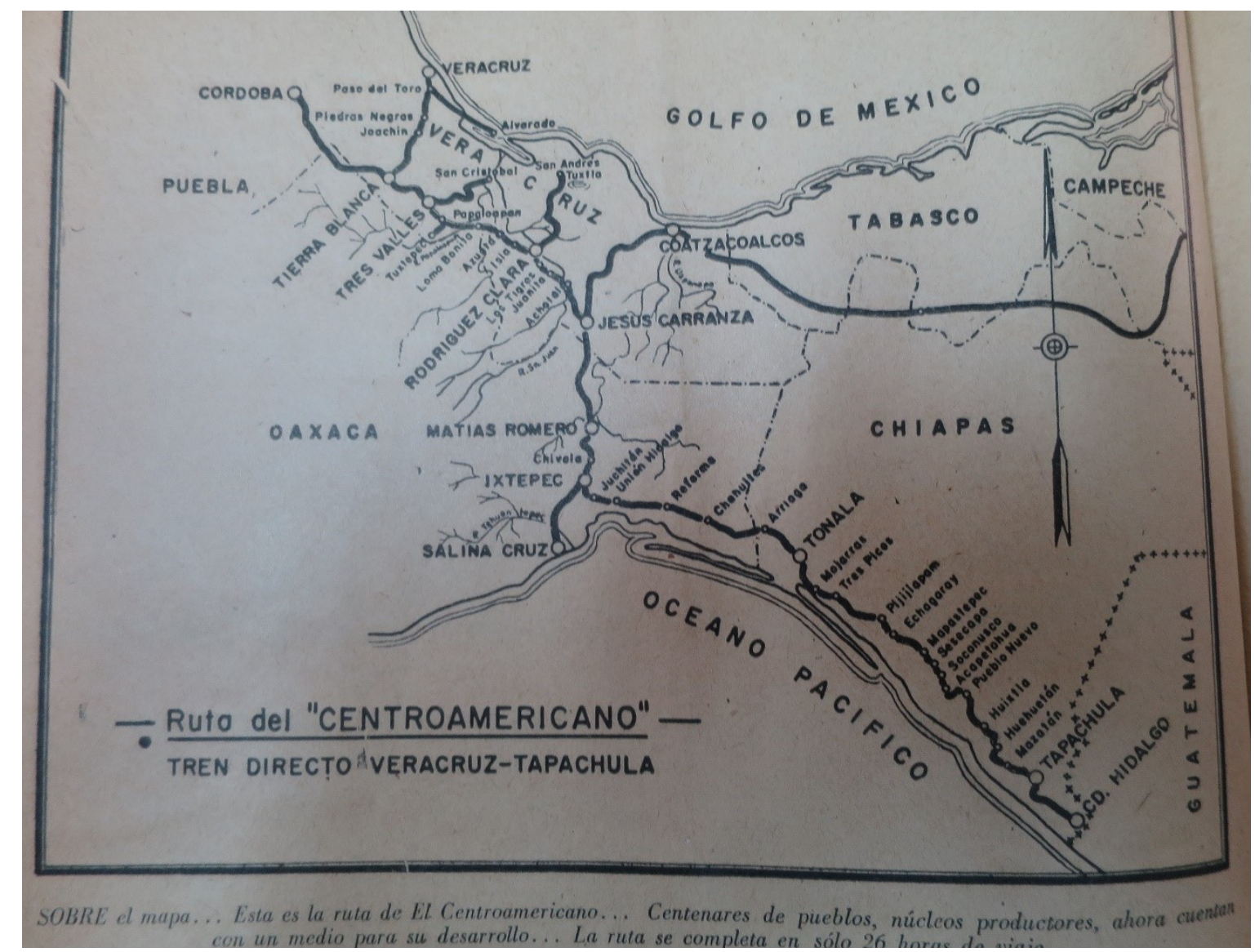

\section{Figure 13- Map of Route of Central American Train (Direct Service Between VERACRUZ -TAPACHULA)}

Source: FNM. 1955. Ferronales. Tomo XXV. No. 3-4. marzo- abril 1955: 10. Mexico: CEDIF Archives. 
The introduction of the service was part of a three-year plan to modernize the railways of the southeastern division of the FNM as a means of supporting economic development in Veracruz, Oaxaca and Chiapas (El Diario del Sur 1955). The idea was to enhance the efficiency of railway transport and to stimulate tourism to Mexico from Central and South America; the sleeping cars of the Centroamericano were named after the countries of Guatemala, El Salvador, Honduras, Nicaragua, Costa Rica, Panama, Colombia and Venezuela. The five dining cars were named after the countries of Ecuador, Brazil, Peru, Chile and Argentina ${ }^{30}$ (FNM 1955).

The inauguration of the Centroamericano, of course, was an attempt to eliminate retrasos, and it challenged the mobility interests of the railway workers, las bayunqueras, local lovers and shoppers. The diesel engine technology which the new train service introduced displaced railway workers from jobs. The addition of another train service to the Panamericano Railway - one with faster speeds, fewer stops, and no cargo - also complicated the work of las bayunqueras. Furthermore, its exclusively passenger cars confronted the tren pollero, which was premised on a loose jumbling together of the human and natural in common spaces of convivencia and exchange. Birds rode in passenger cars; people rode in cattle cars; and each stop maintained its local 'aura' (Schivelbusch [1977] 2014) despite the modern disposition of the railway's materiality. And, all of this benefitted from the friction and retrasos (delays) which the ecology produced in interaction with the railway.

\footnotetext{
30 There was either an error or a later adjustment to the names of the different passenger cars noted in the 1955 Ferronales (march/April 1955) publication. A retired passenger car from the Central American train sits in the National Museum of Mexican Railways (Museo Nacional de los Ferrocarriles Mexicanos) in Puebla, Mexico carrying the name 'Dormitorio Argentina,' or sleeping car Argentina. This was discovered during field work in 2015.
} 


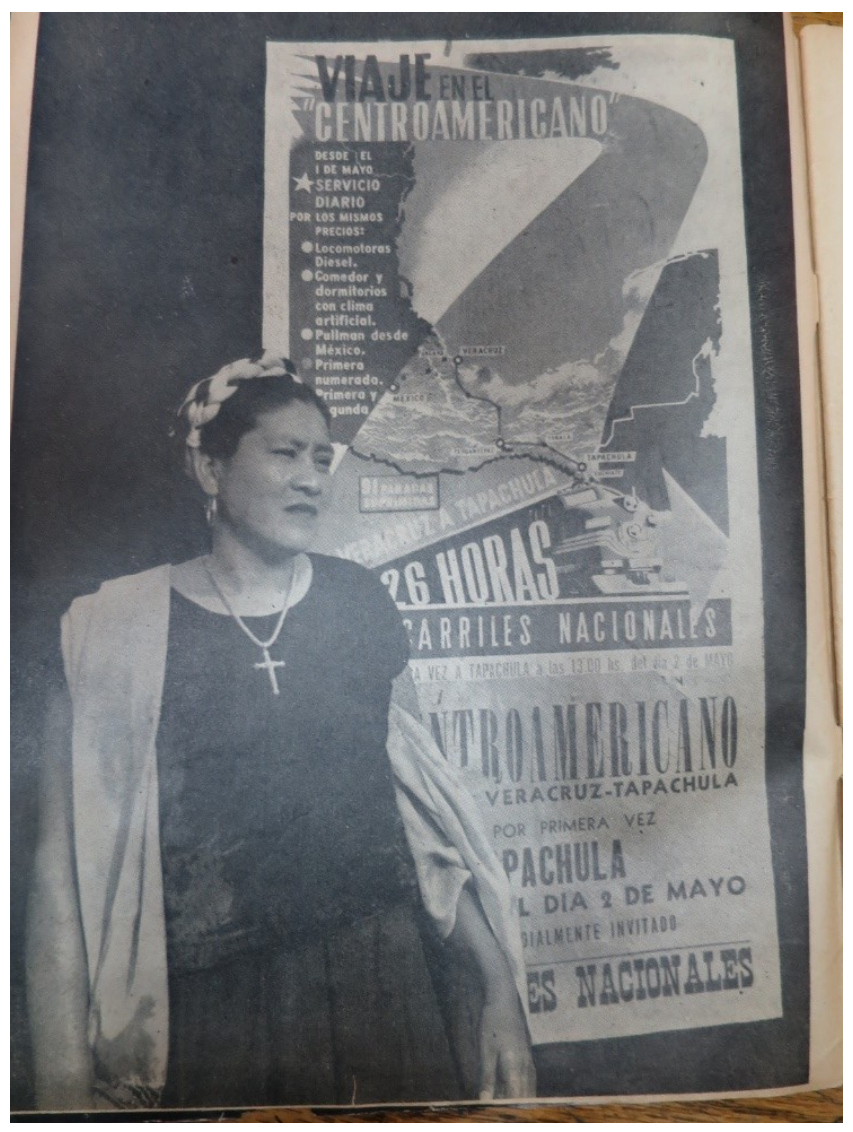

Figure 14- 'MODERn TRADITION' ANNOUNCES THE INAUGURATION OF THE CENTROAMERICANO Source: FNM. 1955. Ferronales. Tomo XXV. No. 3-4. marzo- abril 1955. Mexico: CEDIF Archives.

Retrasos were useful for strengthening the local circuits of economic exchange and consumption. Every stop was a new marketplace for the bayunqueras and passengers to exchange goods and stories. The more stops and frictions, the more opportunities for exchange. Slow movement was a tactic that suggests a different set of aims or values with respect to mobility. Nevertheless, whilst these mobilities were rooted in tradition, they were not considered compatible with the infrastructural state-making which, at that time, sought roadways, cultural inventories and tourist mobilities to economically reinvigorate and politically integrate a postrevolutionary Mexico. As this chapter suggests, the traditions of el pueblo that were to be 
packaged and circulated to stimulate international tourist mobilities could not be counter-

modern. State-making demanded modernity with tradition, but not retraso. ${ }^{31}$

\footnotetext{
${ }^{31}$ One episode in the politics of retraso which I did not address at length in this chapter, but which likely influenced the decision and/or timing of the inauguration of the Centroamericano, is the 1954 military coup in Guatemala. The US-backed coup replaced President Arbenz with President Castillo Armas, giving rise to la guerrilla and 40 years of civil war in Guatemala. In Chiapas, left-leaning Artemio Rojas Mandujano- later nicknamed El Pollino- unites 100 people on Oct. 18, 1955 in the main plaza of Tuxtla, asking for the resignation of the Governor for 'faltas de obra de gobierno.' Rojas was jailed, and the movement was repressed. Local newspapers were censored (which is why no references to this were found in my newspaper archives research). Rojas tried to overcome the censorship by publishing the newspaper Chiapas Libre in 1956. This was also quickly censored. La Voz del Sureste, which published news about the region from the safety of Mexico City did, however, publish some news about these events.
} 


\section{Chapter 3- The Politics of Passengers}

"...the girls that sold, horchata helada (a cold rice drink), and coffee with milk-one hot and one cold beverage. They would call out ';Café con leche! ¡Horchata helada! ...actually, I can still hear their melodious voices clearly: 'ipescado baldado- tiene pescado!' o 'ipollo!' 'iqueso pollo!' and all that; they were, above all women that sold food on the train... In each station, they offered you things through the windows, and if the train stopped for longer, people got on the train and walked the aisles, selling all sorts of things. ... the people were accustomed to this type of thing. The people used to eat there; there were no railway cafeterias where you could stop to buy a sandwich, a hamburger, a Coca Cola or some chips. There was none of that. It existed elsewhere, but not in this particular world. Not yet." (Interview 14-Memories of a railway journey in the 1980s).

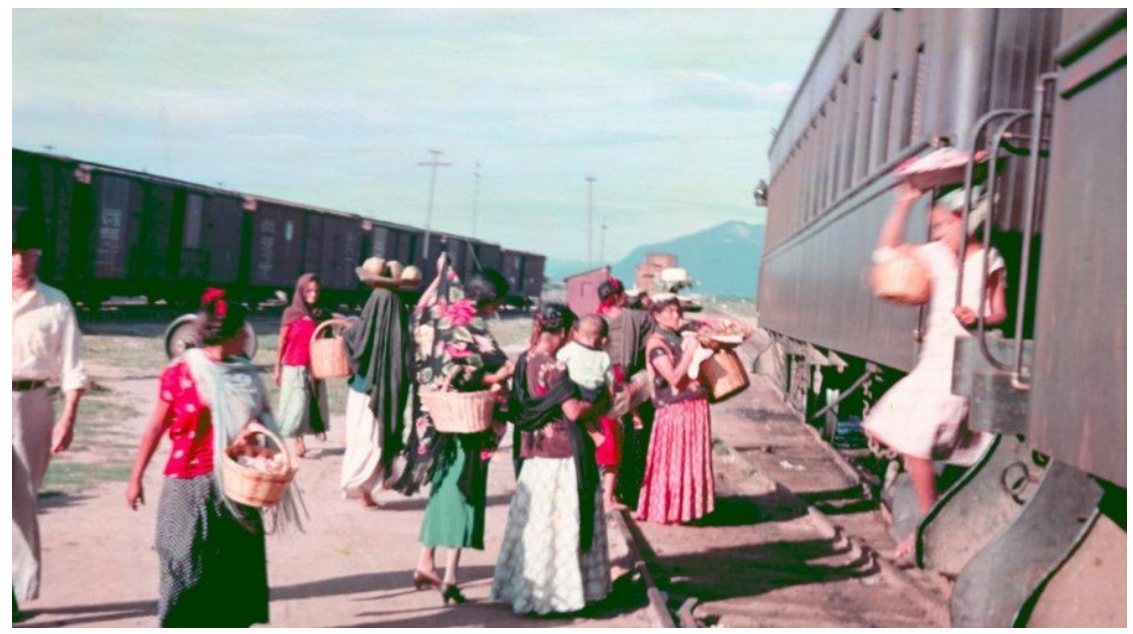

Figure 15- LAS BAyUNQUERAS IN IXTEPEC, OAXACA

Source: 'Ixtepec Oaxaca' (public). Facebook page. Postal de colección \#HechoEnIxtepec. Retrieved August 27, 2015

(https://www.facebook.com/ciudadixtepec/photos/a.690581441057714.1073741828.681073792008479/ $885944014854788 /$ type $=3 \&$ theater $).$

With the rise of alternative modes of transportation in the 1950s (Chapter 2), railway passenger services increasingly came to be understood as a social service which the state 
provided to the poorest and most isolated communities in Mexico, many of which were located in the south. Railway passenger services were subsidized by the Mexican government, keeping passenger ticket prices well below the cost of bus and airline tickets. As such, trains increasingly came to be understood as the mode of transport of los pobres (the poor), that is, those who did not have the means of accessing the more efficient and costly transport services.

Poverty grew significantly in southern Mexico during the 1980s and 1990s, as did the demand for low-cost transport. This was the result of a number of factors. First, the 1982 debt crisis and the 1994 -peso crisis in Mexico impoverished untold numbers of Mexicans. The coffee industry suffered terrible devastation at the same time that the installation of maquiladoras along the US-Mexico border provided incentives for Chiapans to migrate north. Furthermore, and as we will see in Chapter 4, the deportations of Central American and Mexican migrants brought ever-increasing numbers of people to southern Mexico who had ample motivation to return to the United States but, because of the deportation process, did not have the economic means to do so. Demand for railway passenger services thus increased during this period.

Despite rising numbers of passengers in southeastern Mexico, railway passenger services declined dramatically in the late 1980s and early 1990s. This chapter examines why. It suggests that during the 1990s, infrastructural state-making shifts once again. This time it involves railway restructuring, unsettlement, and human inventories. The chapter illustrates how the restructuring of the railway virtually eliminated passenger services; expelled and dispossessed the locals of their railway livelihoods- primarily the bayunqueras and rieleros (spotlighted in Chapter 2- The Politics of Retraso), and; created jurisdictional nebulousness, which, coupled with the historic tortuguismo of the railway, sets the stage for the emergence of a new type of railway passenger who would ride atop the cars of freight trains. This memory counters beastly 
stories and images by drawing attention to the political and economic processes which helped make this new railway passenger.

\section{Infrastructure Reform. A Global Phenomenon}

At the end of the $20^{\text {th }}$ century, there was a major shift in ideology concerning the role of the state in providing public infrastructure (Campos 2001; Thompson, Budin and Estache 2001; Kessides 2004). For decades, most countries had subscribed to a 'public utility paradigm,' which assumed states were the best owners and regulators of network infrastructure services, such as electricity, telecommunications, water, sewage, natural gas and transportation. This public utility paradigm assumed that network utilities “...were best served- and served bestwhen structured as vertically integrated monopolies [in which a] single entity controlled all facilities, operations and administrative functions and was obliged (in accordance with its public utility responsibilities) to serve on demand within its territory" (Kessides 2004: 35-36). Furthermore, there was reluctance to have markets govern network utilities for fear of monopoly, given the strategic importance of infrastructure, and the large financial investment required for service coverage (Kessides 2004).

Then, in the early 1990s, a new paradigm emerged which questioned the necessity of state-ownership of network utilities and wide-spread assumptions about natural monopolies and regulations. The new paradigm posited that “...network utilities are not monolithic natural monopolies. Rather, they encompass several distinct activities with entirely different economic characteristics- entailing a mix of competition and monopoly elements in supply" (Kessides 2004: 36). The new paradigm advocated an 'unbundling' of all of the component pieces of 
vertically integrated infrastructure, and the separation of those elements deemed competitive from those which were considered 'natural monopoly. ${ }^{32}$ The new paradigm posited that:

Network utilities should be unbundled both horizontally and vertically, with different owners for potentially competitive components and natural monopoly components. For competitive or structurally contestable activities, government interference with market mechanisms and restrictions on ownership should be relaxed, and the scope for introducing competition through horizontal fragmentation should be fully exploited. Only components involving unavoidable natural monopolies or substantial sunk capital should be placed under regulation and perhaps even operated by the public sector (Kessides 2004: 37).

This new paradigm proved appealing to states looking for solutions to new fiscal pressures and economic conditions. In the late 1970s, the United States faced problems such as stagflation, energy crises, inflation, low national productivity and international competitivity, environmental concerns and the bankruptcy of key industries such as the railways. These issues all motivated the US to deregulate network utilities. In the UK, infrastructure privatization was considered a means of balancing the books in the 1980s. The European Union saw state monopoly on network utilities as a problem for integration; The EU thus issued directives, calling for liberalization of network utilities (without speaking to ownership) as a means of building a common space for the free movement of goods, services, people and capital. In the global south, the reasons for infrastructure reform were often connected to debt and fiscal crises in the 1980s, as well as poor performance of the network utilities industries and the

\footnotetext{
${ }^{32}$ That is, those in need of heavy investment or 'sunk capital' to enter the market with relatively small market returns.
} 
mismanagement of public enterprises. Because of heavy debt burdens during this period, many countries were unable to make the public investments in infrastructure needed for their maintenance, thereby making their network utilities industries even less competitive.

In this context, infrastructure reforms were introduced around the world between 1990 and 2001. They restructured a wide range of 'network utilities,' including electricity, telecommunications, railroads, water supply, and natural gas according to free market rationales and values of efficiency and productivity. The way in which they were restructured depended on the characteristics of their country and the network utilities of concern (Kessides 2004). As we will see in the following section, in the case of railways, railway restructuring around the world vertically 'lifted' or separated railway operations from their tracks.

\section{Unbundling the Railways: The Question of Vertical Separation}

Infrastructure reforms brought restructuring to national railways around the world during the 1990s ${ }^{33}$ In Asia, the Japan National Railway was privatized over a period of 10 years, beginning in 1987 (Mitzutani 1999). In Africa, 25 of the 34 state-run railways restructured between the early 1990s and mid-2000s (Roy and Kieran 2006). In Europe, twenty countries began some form of railway restructuring between 1989 and the early 2000s, and particularly after the 1992 signing of the Treaty of Maastricht (Nash 2008). British Rail was privatized between 1993 and $1997^{34}$ (Preston and Robins 2013; Nash 2008). Finally, in Latin America, Argentina sold concessions of its freight and commuter networks between 1990-93, and Brazil

\footnotetext{
${ }^{33}$ One exception to this trend was China where the infrastructure state was revived, and rail lines have been built around the country (Guldi 2012).

${ }^{34}$ These dates refer to the initial restructuring of operations and infrastructure, but an argument could be made that the privatizations period began in the 1980s and continued into the 2000s. Britain's ancillary railway businesses, such as hotels, ferries and the manufacturing of railway's rolling stock, began the privatization process earlier: 1981-1989. Well into the 2000s, the railways' regulatory bodies were still being re-structured, particularly following the Hatfield accident in 2000 (Preston and Robins 2013).
} 
privatized state-run rail services between 1996-98 (Estache, González and Trujillo 2002). Chile and Bolivia also went through similar processes (Campos 2001). And, as we will see later in this chapter, Mexico restructured its state-owned railways during the 1990s.

Most states explained their decisions to restructure railways in the language of fiscal responsibility, efficiency and competitiveness. Railways, it was argued, were draining the public purse. At the beginning of the 1990s, many states saw increased fiscal pressures on government coffers, which had long subsidized railways services (Campos 2001; Thompson et al. 2001). At the time, railways required heavy subsidies to cover operating costs, outdated operating practices, and infrastructure maintenance. Labour costs had also ballooned, placing operating costs into the red and draining public treasuries. Railway infrastructure was deteriorating and increasingly obsolete. The need to upgrade the infrastructure was urgent, but there were no funds available to do so. The lack of funds to upgrade infrastructure and rolling stock, reduced the efficiency of railways (costs, timeliness, accidents vs. successful transport) and reduced their capacity to compete with other sources of ground and water transport (Estache et al. 2002).

Decline in the railways' overall transport market share was a common trend around the world in the period after the second World War. In Latin America, for instance, the overall volume of movement of overland freight and passengers increased by $50 \%$ during the $1970 \mathrm{~s}, 80 \mathrm{~s}$ and 90 s, but the railways' ability to capture their share of that market declined relative to other options (Campos 2001: 86). A similar trend occurred in Japan, where the railways' capture of passenger services fell from over $80 \%$ in 1955 to $38.5 \%$ in 1985 ; its decline in share of freight market declined from $52.9 \%$ to $5 \%$ over this same period (Mitzutani 1999). In the decades leading up to privatization, British Rail also saw a decline in its share of the transportation market and a rise in its dependence on the state for regular financial support (Wellings 2014). 
Campos (2001) attributes the decline in railways' transport market share in Latin America to rapid road development and to railway regulations that grew obsolete because of their inability to react in a timely manner to the changing mobility context. Similarly, in Japan, the decline in railways' share of the transport market has been attributed to a growth in the Japanese economy in the 1970s, the rise of automobility and air travel, and internal issues, such as bureaucratic and ineffective organization of the public corporation and conflicts with labour unions (Mizutani 1999).

There were different approaches to railway restructuring around the world. To prevent private monopoly on the whole of their national railway system, states horizontally -separated their national railways into several regional or local concessions for freight and passenger services. In some cases, the railway's track maintenance, rehabilitation and service provision were bundled together to be provided by a single concessionary (Estache et al. 2002). Other states, particularly in Europe, ${ }^{35}$ vertically separated their railway infrastructure from its operations and transport management in addition to horizontal separation (López and Segado 2010; Estache et al. 2002).

In Sweden, for instance, infrastructure and railway operations were vertically separated in 1989, with the creation of the state-owned infrastructure manager Banverket (Nash 2008). The initial vertical separation in 1989 was designed to promote fair competition between railways and roads (Nash 2008). It was also designed to separate what were considered two spheres of the railway with different interests: commercial (operations) from non-commercial (infrastructure management) (Nash 2008). In Spain, vertical separation was done by separating the Spanish

\footnotetext{
${ }^{35}$ European legislation- treaty of Maastricht- now mandates that there be a separation of powers and accounts where infrastructure and operations are concerned (Nash 2008).
} 
Railway Network (RENFE) from the Railway Infrastructure Agency (ADIF) and incorporating new railway operators (López and Segado 2010). In Japan, the infrastructure-operation separation involved the horizontal division of the Japanese National Railway into seven Japanese Railway Companies (six offering passenger services and one freight services), and the creation of the Shinkansen Holding Corporation (SHC), which maintained ownership over the four Shinkansen (High speed train) rail lines and leased their operations to four different Japanese Railway Companies. Eventually, in 1991, ownership and operations of all high-speed railways in Japan were sold to three of the passenger-service oriented Japanese Railway Companies (Mizutani 1999). British Rail was both vertically and horizontally separated by establishing the company Railtrack for infrastructure management and creating 25 companies for passenger train operations and 3 companies dedicated to freight operations (Wellings 2014; Preston and Robins 2013).

The question of vertical separation of the railways is a complex one, which has been widely debated. For some, vertical separation was a mistake, evidenced by the bankruptcies and fatal accidents which British Rail experienced shortly after the vertical separation and privatization of both railway infrastructure and operations. ${ }^{36}$ Wellings (2014) argues that it is not coincidence that railway infrastructure and operations had always been vertically integrated since the $19^{\text {th }}$ century advent of the railways (which were introduced as private enterprise, of course). He argues that railway infrastructure has a unique relationship with the mobilities it facilitates:

\footnotetext{
${ }^{36}$ Five fatal railway accidents occurred in Britain in the five years immediately following privatization (1997-2002), pushing Railtrack- the privatized infrastructure company- into receivership and generating debates about the impact of railway restructuring on safety (Wellings 2014).
} 
The vertical segregation of infrastructure had been applied in other privatisations on the grounds that the grid or infrastructure was a natural monopoly. There was no point in having two competing rail networks, just as there seemed little point in having competing electricity, gas, telecommunications or water networks. In cases of gas, electricity, water and telecommunications, the arguments for separation seem straightforward. It would be (comparatively) simple to separate the management of the infrastructure or network (gas, mains etc.) through which the supplies flowed freely. But the relationship between the technology of what moves and the grid it moves on seems intuitively different from those in the others cited. At the very least, trains need timetabling to avoid collision. This arguably raises issues about the structure of organizations that undertake railway operations (Wellings 2014: 257).

Still, for others, vertical segregation was the only way to achieve efficiency and market rule (as opposed to political rule) of the railways (Wellings 2014). Among those who advocated vertical separation, some argued that the state must remain involved in the natural monopoly components of the infrastructure. So, in the case of the railways, "tracks and railway signals were considered natural monopoly components, and train operations and maintenance facilities were considered competitive components (Kessides 2004: 37). Others, however, advocated the elimination of state regulation altogether, arguing that markets were capable of regulating competition for (rather than in) the provision of the natural monopoly components. Private competitors, under this model, would bid for fixed-term monopoly franchises and be motivated to offer excellent service to win the next bid (Kessides 2004: 38).

In short, the vertical separation of infrastructure and the operations was a common concern and approach to railway restructuring. In some cases, such as in Britain, states sold the 
operations and infrastructure to private companies. In other cases- such as Mexico, vertical separation involved state ownership of the infrastructure and the private concession of operations. In the following sections, we will take a closer look at Mexico's approach to railway privatization and how it impacted railway passenger services, livelihoods, and jurisdictional 'clarity' with regards to track maintenance and security.

\section{Railway Restructuring in Mexico}

At the beginning of the 1990s, the continued uptick in volume and speed of global mobilities and, particularly in the case of Mexico, the looming prospect of a free trade agreement with United States and Canada increased existing pressures for Mexico to improve its railway technology and infrastructure to be able to participate effectively (Gorostiza 2011; Sacristián 2002). At the same time, FNM's deficit continued to grow. Restructuring programs in the first half of the 1990s were a preparation for privatization in the second half of the 1990s. The idea was that private investors would only invest in railways if their prospects looked promising, so a short period of 'renovations' was necessary before the sale of the house (Campos 2001). In response, in 1991, FNM introduced a structural adjustment program (Programa de Cambio Estructural 1991-1994) in order to address its growing deficit and to optimize the resources utilized for the operation of the railway. The program also aimed to delegate to private sector entities a number of complimentary activities connected to railway operations (Gorostiza 2011: 7-8 and 14).

In December 1994, Mexico swore in a newly-elected president Ernesto Zedillo Ponce de León, who immediately introduced an Emergency Economic Plan for Mexico comprising a series of legislative reforms designed to address the country's economic difficulties. Among 
these were four reforms, which, over the following 18 months, would allow for the privatization of Mexico’s railway operations.

First, on March 2, 1995, DOF published legislative reforms to article 28 of Mexico’s Constitution which removes the railways from the list of strategic areas in which state was legislated to hold exclusive ownership and administrative powers, thereby opening up railway operations in Mexico to private investors (Gorostiza 2011: 44; Campos 2000:100). Eight weeks later, on April 28, 1995, a second piece of legislation- La Ley Reglamentaria del Servicio Ferroviario- would establish the terms upon which private entities could engage in the operations, construction and maintenance of railway lines in Mexico. With the law, the Mexican state would maintain ownership of the railway lines and lands, thereby protecting its sovereignty. Likewise, the law stipulated that the concessions could be granted for a maximum period of 50 years (renewable) to private Mexican entities with no more than 49\% non-Mexican shareholders. Private entities were free to set tariffs as they wished ${ }^{37}$ and negotiate with other private entities to coordinate rights to passage on particular lines of shared interest (Gorostiza 2011: 44). On November 13, 1995, the DOF published general guidelines for opening up investment in Mexican railway system to private entities. (Lineamientos generales para la apertura a la inversion en el Sistema ferroviaria Mexicana) (Gorostiza 2011: 46). Then, finally, on September 30, 1996, DOF published the Reglamento del Servicio Ferroviario, which would lay out the legal rights and responsibilities of the Secretaría de Comunicaciones y Transporte (SCT) and concessionaries in terms of the provision of railway services and infrastructure (Gorostiza 2011: 7-8 and 45).

\footnotetext{
${ }^{37}$ In cases of monopolies or practices which were not in the interests of the Mexican state, the SCT reserved the right to intervene.
} 
Once the legislative stage was set, FNM and SCT officials convened a Comité de Restructuración del Sistema Ferroviaria Mexicano to map out strategies for privatization. This committee decided that the privatization of Mexico's railways was to be carried out by regional segmentation, that is, by first dividing FNM railways into three main regional sectors -

Ferrocarril del Noreste, Ferrocarril del Pacifico Norte, and Ferrocarril del Sureste- and a series of short lines (vias cortas) to be administered separately by regional public offices. Then the government's shares for each of these regional sectors were to be sold to the highest bidder (Gorostiza 2011: 7-8). In 1997, together, the three main regional sectors held 76\% of the more than 20,000 kilometres of track in Mexico, and, perhaps more importantly, some $96 \%$ of the total tons per kilometre of cargo transported by FNM (Sacristián 2002: 107). ${ }^{38}$

In July 1997, the Northeast Railway (Ferrocarril del Noreste) was the first -and most important -cargo sector- to be transferred to a private entity. Transportación Ferroviaria Mexicana (TFM) agreed to the price of 11,072 million pesos and a commitment to infrastructural investment of 800 million dollars over five years. ${ }^{39}$ That same year, the concession for the Pacific North Railway (Ferrocarril del Pacifico Norte) was sold to Grupo Ferroviaria Mexicana (Ferromex) for 4,197 million pesos and a three-year commitment to invest 3,368 million dollars in infrastructure over three years. On recommendation from el Poder Legislativo, in 1998, FNM's Southeast Railway sector (Ferrocarril del Sureste) was further divided into six short

\footnotetext{
${ }^{38}$ The Pacific North sector (Pacifico Norte) held $43 \%$ of track and transported $47 \%$ of total tons per kilometre; the Northeast sector (el Noreste) held $25 \%$ of track and $39 \%$ of total tons per kilometre; and the Southeast sector (el Sureste) held $8 \%$ of total track and 10\% of total tons per kilometre (Sacristián 2002: 107).

${ }^{39}$ At the time of the concession, Transportación Ferroviaria Mexicana (TFM) comprised two groups of investors: Transportación Maritima Mexicana (TMM) and Kansas City Southern Lines and Industries (KCSI). TFM begins operations in 1997 and, in 2005, Kansas City buys out TMM and becomes the sole shareholder under the name Kansas City Southern Mexico (KCSM). This was approved by Comisión Nacional de Inversiones Extrajeras and La Comisión Federal de Competencia (Gorostiza 2011: 48).
} 
lines. These were: Ferrocarril del Sureste (linea troncal); Ferrocarril del Mayab

(Coatzacoalcos-Mérida); Ferrocarril del Istmo de Tehuantepec (Salina Cruz-Coatzacoalcos);

Ferrocarril de Chiapas (Tapachula-Ixtepec); Ferrocarril del Sur y Ferrocarril de Oaxaca (SCT 1998). Later that year, Tribasa (Ferrosur) was granted the concession for the main trunk of the Southeast Railway for the price of 2, 898 million pesos and a commitment to infrastructural investment of $\$ 2,500$ million dollars over ten years (Gorostiza 2011: 47-49).

TABLE 1- TRANSFER OF RAILWAY LINES TO PRIVATE CONCESSIONARIES

\begin{tabular}{|c|c|c|c|}
\hline $\begin{array}{l}\text { Railway lines } \\
\text { and stations }\end{array}$ & Name of concessionary & $\begin{array}{l}\text { Transfer date } \\
\text { concessionaries }\end{array}$ & $\begin{array}{l}\text { Price of } \\
\text { concession } \\
\text { (millions of } \\
\text { dollars) }\end{array}$ \\
\hline Pacific North & $\begin{array}{l}\text { Grupo Ferroviaria Mexicana } \\
\text { (a.k.a Ferromex) }\end{array}$ & February 18, 1998 & $527,000,000$ \\
\hline Northeast & $\begin{array}{l}\text { Transportación Ferroviaria } \\
\text { Mexicana (TFM) -Kansas } \\
\text { City Southern Mexico } \\
\text { (KCSM) est. } 2005\end{array}$ & July 1997 & $1,384,000,000$ \\
\hline $\begin{array}{l}\text { Southeast } \\
\text { (main trunk) }\end{array}$ & $\begin{array}{l}\text { Tribasa } \\
\text { (a.k.a. Ferrosur) }\end{array}$ & December 1998 & $322,000,000$ \\
\hline $\begin{array}{l}\text { Mexican } \\
\text { Valley } \\
\text { Railway } \\
\text { Terminal }\end{array}$ & $\begin{array}{l}\text { TFM, Ferromex and Ferrosur } \\
\text { and federal government each } \\
\text { administer } 25 \% 40\end{array}$ & April 30, 1998 & \\
\hline $\begin{array}{l}\text { Chiapas and } \\
\text { Mayab } \\
\text { Railways }\end{array}$ & $\begin{array}{l}\text { Compañía de Ferrocarriles } \\
\text { Chiapas-Mayab }\end{array}$ & September 1999 & $2,000,000$ \\
\hline $\begin{array}{l}\text { Isthmus of } \\
\text { Tehuantepec } \\
\text { Railway (FIT) }\end{array}$ & Federal government & 1999 & $\mathrm{n} / \mathrm{a}$ \\
\hline
\end{tabular}

Sources: SCT 1998; SCT 2001; Sacristián 2002

\footnotetext{
${ }^{40}$ The long-term plan was for the government to administer $25 \%$ of the concession for Mexican Valley Railway Terminal until a private entity was granted concession to rehabilitate railway infrastructure for the purposes of connecting intra-metropolitan railway passenger services Metropolitan Area of Mexico City (SCT 1998).
} 
The remainder of the Southeast Railway sector was privatized in a separate round of concessionary bidding for a number of short lines (vias cortas) where the transport of goods and people was smaller and more localized. On April 17, 1997, the SCT opened the competition for concessions for a number of short lines, which included Coatzacoalcos-Merida (Mayab Railway), and Ixtepec-Cd. Hidalgo (Chiapas Railway) in the south (Gorostiza 2011:50). On August 28, 1999, for the price of 141 million pesos, roughly 2 million dollars (Sacristián 2002), the SCT granted the concession for cargo transport along the 'Chiapas' (Ixtepec-Cd. Hidalgo) and 'Mayab' Railways (Coatzacoalcos-Mérida) to the Chiapas-Mayab Railway Company (Compañia de Ferrocarriles Chiapas-Mayab), owned by the U.S.-based Genesee \& Wyoming. At the time of concession, the Chiapas-Mayab rail lines in Mexico's south held a total of 9\% of national railway track and carried $1 \%$ of total tons transported per kilometre (Sacristián 2002:107) ${ }^{41}$.

\footnotetext{
${ }^{41}$ Sacristián (2002) cites FNM stats from 1997 which provide percentages which only account for $91 \%$ of the total kilometres of Mexico's railway tracks and $99 \%$ of total tons per kilometre transported. One might imagine that the remaining $9 \%$ of track and $1 \%$ of tons per kilometre correspond to FIT since it is not listed in the chart provided in this publication
} 


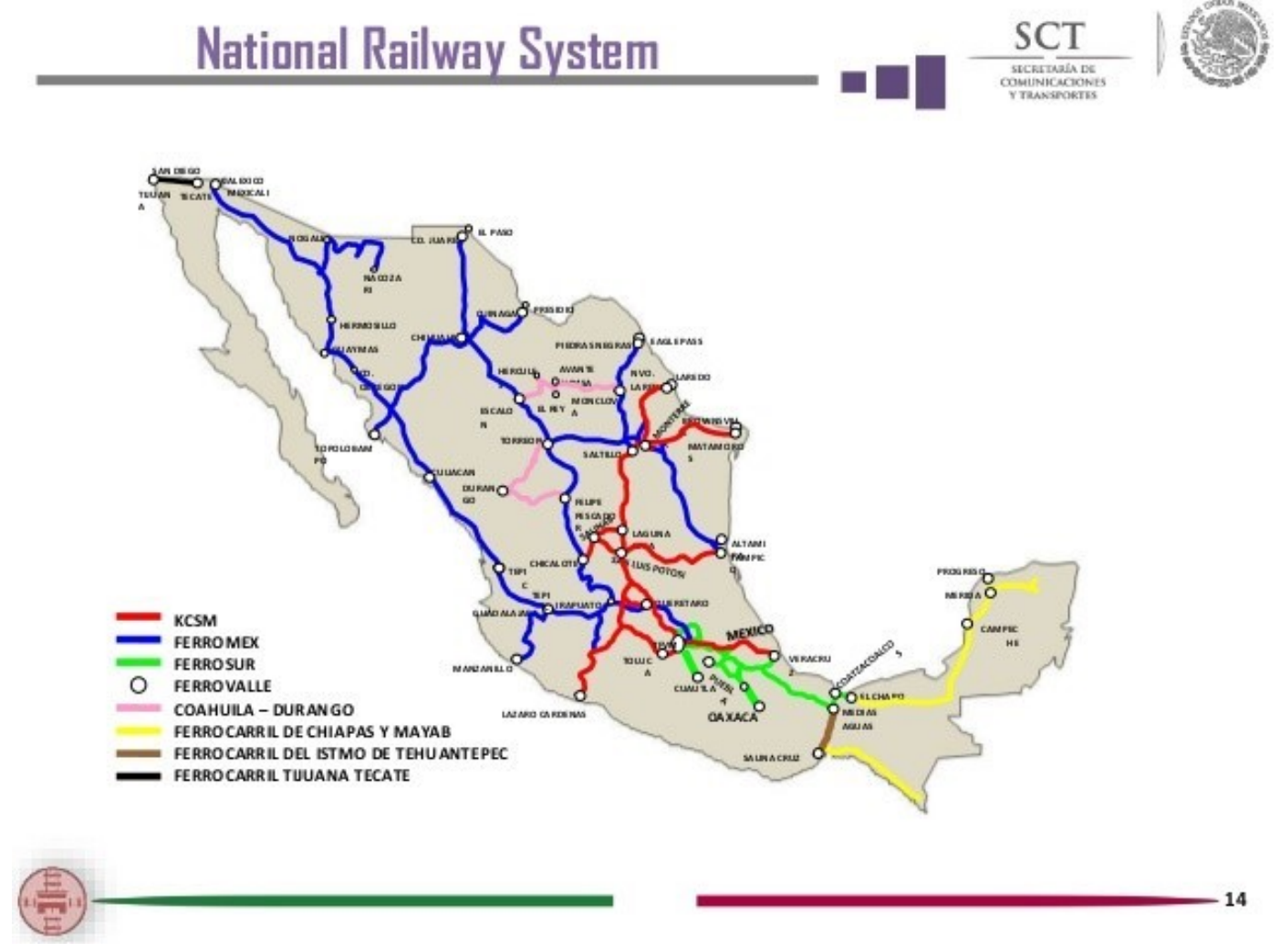

Finally, the National Railway of Tehuantepec was excluded completely from concessions because of its strategic and military importance for Mexican sovereignty (Gorostiza 2011: 46) ${ }^{42}$. Instead, a parastatal company called the Ferrocarril de Istmo de Tehuantepec S.A. de C.V. (FIT) was established in 1999 for the federal government to engage in railway administration and operations along the length of the Isthmus of Tehuantepec. Private entities were permitted to solicit FIT for the rights to utilize this rail line for the transportation of commercial goods and people (Gorostiza 2011:49-50). The Chiapas-Mayab Railway Company was granted this right (derechos de paso y arrastre) to operate between Coatzacoalcos and Salina Cruz along the

\footnotetext{
${ }^{42}$ During the nineteenth century, Mexico, Nicaragua and Panama were all being considered as possible locations for the construction of a major canal that would connect the maritime routes of the Pacific Ocean to those of the Caribbean. Because of its geographical features, the Isthmus of Tehuantepec was considered the ideal place to build a canal in Mexico. While the canal was eventually constructed in Panama, Mexico still considers the Isthmus a strategic space for building markets and security. There is an important military base in the town of Ixtepec, Oaxaca (where the Panamericano intersects with the Isthmus of Tehuantepec), and, during the Second World War, the military base on the Isthmus was offered as infrastructural support to the United States.
} 
Tehuantepec Isthmus, and Ferrosur was extended the right to move between Medias Aguas and Coatzacoalcos (Gorostiza 2011:50; SCT 2001:30).

\section{The Impact of Restructuring}

The restructuring of the railway had important impacts on several aspects of the material and social infrastructure of the Pan-American Railway. These included: 1.) Passenger services; 2.) Railway Livelihoods (ie. space of employment for rieleros and bayunqueras), and; 3.)

Jurisdictions. The following subsections examine each of these impacts individually.

\section{Passenger Services}

The restructuring and privatization of Ferrocarriles Nacionales de México (FNM) led to a massive reduction and deterioration of railway passenger services throughout Mexico. In little more than a decade, the total volume of railway passengers in Mexico dropped from approximately 18.5 million in 1988 to less than a quarter of a million in 2001 when FNM was officially dissolved and the railways' privatization was more or less complete (SCT 2013; SCT 2003; SCT 1997).

\section{TABle 2- Total Volume of InTER-Urban Railway Passengers in MÉXICO 1988-2005}

$\begin{array}{llllll}\text { Year } & \begin{array}{l}\text { Total number of } \\ \text { passengers } \\ \text { (thousands) }\end{array} & \begin{array}{l}\text { Passengers/km } \\ \text { (millions) }\end{array} & \text { Year } & \begin{array}{l}\text { Total number } \\ \text { of passengers } \\ \text { (thousands) }\end{array} & \begin{array}{l}\text { Passengers/km } \\ \text { (millions) }\end{array} \\ 1988 & 18,487 & 5,619 & 1997 & 5,092 & 1,508 \\ 1989 & 15,898 & 5,383 & 1998 & 1,576 & 460 \\ 1990 & 17,149 & 5,336 & 1999 & 801 & 254 \\ 1991 & 14,902 & 4,686 & 2000 & 334 & 82 \\ 1992 & 14,740 & 4,794 & 2001 & 242 & 67 \\ 1993 & 10,878 & 3,219 & 2002 & 237 & 69 \\ 1994 & 7,189 & 1,855 & 2003 & 270 & 78 \\ 1995 & 6,678 & 1,899 & 2004 & 253 & 74 \\ 1996 & 6,727 & 1,799 & 2005 & 253 & 73\end{array}$


Sources: SCT. Anuarios estadísticos ferroviarios 2013, 2003 and 1997. México, DF: Dirección General de Transporte Ferroviario y Multimodal. SCT.

The disappearance of railway passenger services is often attributed to a loss of demand because of the railways' inability to compete with the speed and efficiency of bus services. Nevertheless, passenger train capacity/occupancy rates in southern Mexico tell a slightly different story. For instance, one FNM report concluded that the 1.5 million second class passenger decline in 1993 was not a result of lack of demand but rather a lack of passenger cars available to service the track, as many regular passenger trains ran with more than $100 \%$ occupancy rate in 1993 (FNM 1994a: 2). While, there was a program to rehabilitate passenger cars at the time, only $10 \%$ of the total program budget was assigned to rehabilitate the south's passenger equipment and just 12 of the 67 passenger cars rehabilitated that year ran through the region (FNM 1994:11).

When the FNM structural adjustment program began in 1991, a total of five passenger trains serviced southern Mexico. ${ }^{43}$ As the Table below indicates, regular passenger trains travelled between Veracruz-Tapachula (Trains no. 101 and 102) and Ixtepec-Tapachula (Trains 169 and 170), and; three mixed cargo-passenger trains (mixtos) ran between Cd. HidalgoTapachula (no. 221 and 222), Salina Cruz-Coatzacoalcos (no. 223 and 224) and MeridaCoatzacoalcos (no. 303 and 304) (FNM 1991).

\section{Table 3- Passenger Services Available in Southern MeXico In 1991}

\begin{tabular}{|l|l|l|l|l|} 
Train no. & Route & $\begin{array}{l}\text { Scheduled } \\
\text { Travel Time }\end{array}$ & $\begin{array}{l}\text { Passenger } \\
\text { services } \\
\text { available }\end{array}$ & Passenger capacity/ class \\
\hline
\end{tabular}

\footnotetext{
${ }^{43}$ At this time, FNM ran three types of passenger trains in Mexico: Star (Estrella), Regular (Regular) and Mixtos (Mixed). Regular passenger trains comprised locomotives exclusively pulling passenger cars of distinct classes. Mixed trains comprised locomotives pulling both passenger and freight cars. Star passenger trains were never offered in southern Mexico.
} 


\begin{tabular}{|c|c|c|c|c|}
\hline $\begin{array}{l}\text { No. } 101 \\
\text { and } 102\end{array}$ & $\begin{array}{l}\text { Veracruz- } \\
\text { Tapachula }\end{array}$ & $21 \mathrm{hrs}$ & Regular & $\begin{array}{l}\text { Total capacity } 4960 \\
1^{\text {st }} \text { class } 2480 \\
2^{\text {nd }} \text { class } 2480\end{array}$ \\
\hline $\begin{array}{l}169 \text { and } \\
170\end{array}$ & $\begin{array}{l}\text { Ixtepec- } \\
\text { Tapachula }\end{array}$ & $13-13: 25 \mathrm{hrs}$ & Regular & $\begin{array}{l}\text { Total capacity } 4960 \\
2^{\text {nd }} \text { class only }\end{array}$ \\
\hline $\begin{array}{l}221 \text { and } \\
222\end{array}$ & $\begin{array}{l}\text { Cd. Hidalgo- } \\
\text { Tapachula }\end{array}$ & $1 \mathrm{hr} 20 \mathrm{mins}$ & Mixed & $\begin{array}{l}\text { Total capacity } 4960 \\
2^{\text {nd }} \text { class only }\end{array}$ \\
\hline $\begin{array}{l}223 \text { and } \\
224\end{array}$ & $\begin{array}{l}\text { Salina Cruz- } \\
\text { Coatzacoalcos }\end{array}$ & $8-9$ hrs & Mixed & $\begin{array}{l}\text { Total capacity } 7,448 \\
1^{\text {st }} \text { class } 2480 \\
2^{\text {nd }} \text { class } 4,960\end{array}$ \\
\hline $\begin{array}{l}303 \text { and } \\
304\end{array}$ & $\begin{array}{l}\text { Merida- } \\
\text { Coatzacoalcos }\end{array}$ & $13 \mathrm{hrs}$ & Mixed & $\begin{array}{l}\text { Total capacity } 4960 \\
1 \text { st class } 2480 \\
\text { 2nd class } 2480\end{array}$ \\
\hline
\end{tabular}

SOURCE: FNM 1991

In January 1992, José Manuel Perez López, station chief announced in the press that the mixed train service known as the 'tren pollero' (no. 169 and 170) would be discontinued (García 1992). In 1994, FNM carried out a cost-benefit analysis of existing passenger services in order to reduce FNM's operation costs and personnel, and to improve efficiency in the use of their equipment, particularly by freeing up more locomotives for cargo transport. It recommended that, given the widespread access to road transportation in most regions of Mexico, FNM should: 1.) Cancel all sleeper car services, 2.) Cancel six regular passenger trains with more than one service daily, 3.) Cancel six low-demand passenger trains, 4.) Cancel thirty mixed passengercargo trains, and 5.) Maintain in operation just nineteen high-demand passenger trains (FNM 1994a:1). These actions, it was argued would reduce personnel by 640 and operations costs by 359.9 million pesos per year at the same time it would liberate 60 locomotives to provide (more profitable) cargo services (FNM 1994a:2).

For would-be railway passengers in Mexico's south, these 1994 recommendations were to affect a number of existing operations: 1.) Three of the thirty mixed train services 
recommended for cancellation ran in southern Mexico. These included: Cd. Hidalgo-Tapachula (no. 221 and 222), Salina Cruz- Coatzacoalcos (223 and 224), and Campeche-Coatzacoalcos (no. 303 and 304) (FNM 1994a: 4). While extra-official reports from FNM insiders had revealed that in 1992, administrators had been considering the cancellation of the passenger train service, known as the Centroamericano (no. 101 and 102) due to a lack of modern infrastructure, the Centroamericano was one of the two high demand trains recommended for continued service in southern Mexico following the 1994 cuts ${ }^{44}$ (FNM 1994a: 5; García 1992).

By the time FNM was formally dissolved in June 2001, most railway passenger services had already been eliminated (SCT 2001:29). Because railway passenger services in Mexico and much of the world have never been a profitable venture, it was anticipated that private companies would not offer public transport and would instead focus solely on the movement of cargo ${ }^{45}$. In order to prevent the privatization from isolating a number of communities which, at the time, were completely dependent on the railways for inter-urban public transport, the government included Article 43 in the railway concessions. This article required private companies to provide railway passenger services to isolated communities until the moment when infrastructure could guarantee their access to transport by alternative means. To offset the costs of providing the social service, the federal government paid subsidies to the private companies whose trains passed through these communities.

As the Table 2 of passenger volumes illustrates, in 2001, less than a quarter of a million passengers officially used the service. Approximately half of these passengers occupied the

\footnotetext{
44 The other service was the Córdoba-Merida service (no. 49 and 50) on the Gulf Coast (FNM 1994a: 5).

${ }^{45}$ Passenger services were a contentious issue which also arose in the privatization of Africa's railways. Because passenger services were deemed unprofitable, concessionaries resisted providing much-needed passenger services without state subsidization (Roy and Kieran 2006).
} 
trains which ran as a 'social service' for lack of access to alternative modes of public transport (SCT 2000:30; SCT 2003ㄹ:51; SCT 2004: 54; SCT 2005: 55). In the first years following privatization, the federal government paid between 20 and 25 million pesos per year to diverse private concessionaries for the provision of social railway passenger services ${ }^{46}$ (SCT 2000:30; $\operatorname{SCT}_{2003}^{\mathrm{a}}: 51$; SCT 2004: 54; SCT 2005: 55). These subsidies helped to offset the costs for passenger services on a total of eight railway routes, two of which were located in southern Mexico. In the south, the Chiapas Mayab Railway Company received state subsidies to provide passenger services between Teapa, Tabasco and Palenque, Chiapas along the Gulf Coast's Mayab Railway, and between the cities of Tapachula, Chiapas and Ixtepec, Oaxaca along the Pacific Coast's Chiapas Railway (SCT 2001:30-31).

On December 31, 2001 the Mayab passenger service along the Gulf Coast (TeapaPalenque) was discontinued for unknown reasons (SCT 2002: 40). The subsidization of passenger services along the Chiapas Railway, on the other hand, continued until the first week of October 2005 when Hurricane Stan destroyed the railway infrastructure (SCT 2006: 59). Following the hurricane, the movement of cargo resumed on the northern portion of the Chiapas Railway (between Arriaga and Ixtepec), but, even today, state-subsidized passenger services have not been renewed. As two different informants related during the course of this study -one a government employee of the transport and communications ministry, and another a member of a railway worker family- irregularities in the registration of passengers, the collection of tariffs onboard and for railway administrators repeatedly raised the projected annual costs of the

\footnotetext{
${ }^{46}$ Government of Aguascalientes provided for Adames-Peñuelas route; Tijuana-Tecate was to be provided by the Baja California state government; Ferrosur provided service for the Cuicatlán-Oaxaca route; Felipe PescadorTorreón, Felipe Pescador-San Isidro, and Chihuahua-Los Mochis, has been operated by Ferromex since this operator took over in 1998. The Chihuahua-Los Mochis the only social railway service remaining today, (SCT 2002: 39-40; SCT 2001: 30-31).
} 
passenger service program, providing little incentive for the government to pursue its renewal of this program (Interviews 12 and 15).

\section{Railway Livelihoods}

The restructuring of Mexico's railways, and the subsequent elimination of passenger services, displaced two groups which relied on the railway for their livelihoods: The bayunqueras and the rieleros. While the Centroamericano passenger train service and the Panamerican Highway (see Chapter 2- The Politics of Retraso) did bring new forms of quicker land transport, the bayunqueras and local peasants continued to rely upon the Panamericano's mixed train service (el tren pollero) for their commercial activity. As such, the bayunca and the tourist mobilities were still a major part of the railway scape well into the 1980s. One local that I spoke with recalls a journey he took with his family on the Panamericano during this period. The journey, he recalled, took about two days when the bus would have delivered them to their destination in relatively short order. At the time, he recalls that the people on board the trains were basically curious tourists and "local merchants who carried their goods on their backs and got on and off the train at each stop" (Interview 14).

The bayunqueras continued to rely on the tren pollero because, as one local explained, the highway and bus services didn't reach some of the communities which peasants had ties to and through which the railways passed. Furthermore, the railway stations were usually located in the town centres, a fact which facilitated the up /offloading of cargo. Finally, local merchants who travelled in passenger cars with their bundles could avoid the extra costs of transporting their wares as they moved from one town to another along the Pacific Coast (Interview 15). Consequently, when José Manuel Perez López, FNM station chief, announced the discontinuation of the tren pollero in 1992, stating that: “...the suspension of this train service 
will not affect users -who are mainly indigenous and small-scale farmers- because the

Centroamericano train service passes through thirty rural communities of the Coast of Chiapas"

(García 1992:8; author's translation), what he didn't reveal was that, yes, the Centroamericano

passed through these communities between Ixtepec and Tapachula, but it did not stop in them, as the tren pollero customarily did. Thus, the 1992 elimination of the mixed train service known as el tren pollero (no. 169 and 170) would have seriously restructured if not decimated the local bayunca economy. ${ }^{47}$

Railway workers constituted the other group which was displaced by railway restructuring in Mexico in the 1990s. Prior to restructuring, two thirds of the FNM's operating budget went to labour, and restructuring was considered a means of reducing these costs. In the early 1990s, a Voluntary Retirement Program, reduced FNM personnel by 39,200 through lay offs and early retirements. The FNM reduced the number of its employees from 83,300 employees in 1990 to 44,100 in 1996 when concessions were ready for sale. The number of retired railway workers eligible for pensions also rose during this period from 41,900 to 51,900 (Gorostiza 2010).

\section{Concluding Remarks - On Jurisdiction and Accountability}

The opening of Mexico's national railways to private operations -but not ownershipgenerated jurisdictional nebulousness and bickering (which continues to this day) with respect to the division of responsibilities regarding track maintenance and security on the Chiapas and Mayab Railways in southern Mexico (Ureste and Ángel 2016).

\footnotetext{
${ }^{47}$ It would be worth examining the displacement and possible relocation of the bayunca in the years following railway privatization, as there are many photos of the services industry which emerged along the railway to attend to transit migrants in the late 1990s and early 2000s.
} 
This chapter (together with chapters 4, 5 and 6) suggests that in the 1990s we can observe another shift in state-making, which involves railway restructuring, unsettlement, and; human inventories. This chapter locates railway restructuring in Mexico within a context of global infrastructure reforms, which aimed to reconfigure the role of states with regards to infrastructure. The chapter also illustrates how the restructuring of the railway virtually eliminated passenger services; expelled and dispossessed the locals of their railway livelihoodsprimarily the bayunqueras and rieleros (spotlighted in Chapter 2), and; created jurisdictional nebulousness, which, coupled with the railway's historic tortuguismo (Chapter 2), sets the stage for the emergence of a new type of railway passenger who, as we will see in Chapter 4, would ride atop the cars of freight trains. 


\section{Chapter 4- The Politics of Extraction}

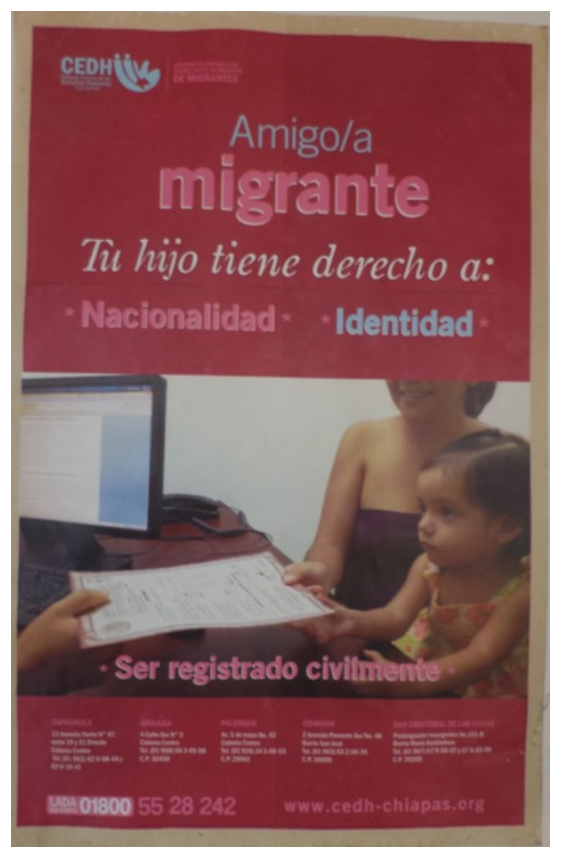

Figure 16- Poster in Embassy Building In TAPachula: 'Migrant Friend: Your Child has THE Right TO A NATIONALiTy \& AN IDENTITY (2012)

Source: 'Migrant Friend: Your Child has the Right to a Nationality \& an Identity. Author's Image.

Tapachula: 2012.

The late 1990s saw several migration phenomena converge in southern Mexico. There was an increase in the number of migrants from Central America and southern Mexico journeying to the US to find work and family members, a trend which particularly grew following the devastation of Hurricane Mitch in 1998. There was also an increase in US deportations of Central Americans, which was connected to US immigration reforms with the Illegal Immigration and Immigrant Responsibility Act (IIRIA) in 1996.

In this chapter, I trace the unsettlement of migrant populations in Mexico and the U.S. between 1988-2005, and I connect these to the emergence of passengers atop freight cars in Mexico. This counter-memory brings deportations and migrations into a single frame by 
focusing on railway infrastructure. Unlike the dominant narratives which find the origins of La Bestia in the darkest and most lawless corners of Central America and southern Mexico, this counter-memory suggests that the origins of the great 'invasion' decried by so many in North America can be found in the unsettlement of populations living in the United States and in Mexico. As this chapter illustrates, in the early 1990s, transport infrastructure becomes a strategic space which facilitates the escape of populations which are unsettled by U.S. deportations, as well as infrastructural and market reforms triggered by NAFTA. Furthermore, it argues that the Panamericano's historic tortuguismo (Chapter 2) and the jurisdictional nebulousness which resulted from its restructuring in this period (Chapter 3) offered a space for unsettled populations to escape state capture.

\section{Unsettlement I. Central America}

During the late 1970s, political, social and economic tensions came to a head in Central America. In 1979, the Sandinistas ousted the Somoza regime in Nicaragua. That same year, a group of military officers overthrew the government in El Salvador in an effort to prevent a Nicaraguan-style Revolution from spreading to that country. In Guatemala, these changing economic, social, and political airs helped grow popular opposition to the military regime -which had been instated in the CIA-backed overthrow of the leftist-Arbenz regime in 1954; the response was infamously brutal (Ferris 1987). As a result, during the 1980s, hundreds of thousands of Nicaraguans, Guatemalans and Salvadorans were forced to flee their homes to escape abduction, torture, massacre and conscription and to address the hunger and hardships of the civil wars which plagued the region (Ferris 1987).

By the mid-1980s, an estimated 1,058,000 Central Americans had sought refuge outside of their countries of origin (Ferris 1987:35). The United States and Mexico received more than 
three quarters of this population: Approximately half of the internationally displaced (585,000 or $55 \%$ ) -primarily from El Salvador- escaped to the United States, and a quarter of this population (250,000 or 24\%) escaped to Mexico (Ferris 1987: 35). Of the 250,000 Central Americans in Mexico, approximately 100,000 were indigenous peasants from Guatemala who settled just across Mexico's southern border in rural camps administered by the Mexican Commission for Refugee Aid (COMAR) ${ }^{48}$; another estimated 100,000 Salvadorans and Guatemalans sought refuge and opportunities in urban areas further into the interior of Mexico; finally, roughly 50,000 Central Americans were thought to be in transit to the United States and Canada (Ferris 1984: $360-362$ ). By the end of the 1980s, it was estimated that close to 750,000 Central Americans resided in Mexico and nearly a million had transited through the country (García 2006:9).

For much of the 1980s, conflicting pressures from within and without the Mexican state's institutions produced inconsistent and often contradictory practices concerning Central Americans' presence in and transit through Mexico (Ferris 1984 and 1987). The 1982 economic crisis in Mexico had much of the population already struggling to keep food on the table, particularly in southern Mexico, and, as such, policy makers were hard pressed to find and justify social or economic resources for the displaced. In addition, some groups argued in favour of restricting Central Americans in Mexico, fearing that, given the difficult economic context, they might help ignite a revolution in Mexico as well. On the other hand, Mexico wished to uphold its long-held tradition and international reputation as a country whose doors were open to exiles, particularly revolutionary intellectuals and professionals fleeing political persecution (Ferris

\footnotetext{
${ }^{48}$ Mexico's Comisión Mexicana de Ayuda a Refugiados, or COMAR, was established in 1981 by the federal government in Mexico to administer camps and advocate on behalf of displaced persons who inhabited them (Ferris 1984).
} 
1984: 366-67). As a result of these contradictory pressures, Central Americans in Mexico were sometimes given direct aid through COMAR and less often they were awarded political exile status; at other times, they were secretly deported or just plain ignored as their visas expired and they slid into in Mexico's informal economy (Ferris 1984: 370).

\section{Unsettlement II. Southern Mexico}

Beginning in the 1980s, changes to the ecological and agricultural conditions in southern Mexico caused rural populations which had traditionally engaged in subsistence farming and seasonal agricultural labour to migrate further afield (Wohlgemuth 2014: 383). Shifts in the rainy periods, increased intensity and frequency of tropical storms, and the problem of extended periods of drought in some regions negatively impacted the crops of sustainable farms, which many communities relied on. Then, in late 1990s, following the signing of NAFTA, there was a decline in the prices for key agricultural commodities, such as coffee and fruit, and an increase in US agricultural products in the Mexican marketplace. As a result, many were pushed out of the cash crops market altogether (Wohlgemuth 2014).

This led many chiapanecos (persons originating from Mexico's southern state of Chiapas) to leave behind their longstanding, local patterns of seasonal agricultural migration to join Central Americans on their international journeys to the United States (Nevins 2007). ${ }^{49}$ At

\footnotetext{
49 In 2001, Fox presented Plan Puebla Panama or Plan Mesoamerica as a solution to the political and economic problems in southern Mexico. According to Wohlgemuth (2014), this plan aimed to integrate the economies of Mexico's southern states of Oaxaca and Chiapas with countries in Central America. It involved funds from the World Bank and the Inter-American Development Bank to "...build, extend, and modernize infrastructure for the creation of urban industrial corridors that include highways, marine ports, railways and airports, and dams in addition energy, gas, and oil pipelines, and other infrastructural amenities in order to attract foreign investment interested In cheap labour and the vast natural biodiversity that the region still offers. The plan included relocating thousands of dispersed subsistence farmers to newly created cities, named 'Sustainable Rural Cities,' as a way of combatting poverty and to stop the Zapatista support through community disintegration" (Wohlgemuth 2014:384).
} 
the time, Mexico's southern state of Chiapas still had large proportions of the local population living outside of many, if not all, of the Mexican state's institutions. To provide a snap shot of this situation, we might consider the following: In 1999, only $47.6 \%$ of births in Chiapas were registered with state institutions in a timely manner; this was well below the national average of $78.8 \%$. By the year 2009 , the timely birth registration rates had grown to $61.7 \%$, but still remained below the national average of 93.4\% (UNICEF and INEGI n.d: 23).

The reasons for this situation are complex, involving historical, political, economic, cultural, and geographic factors. Chiapanecos earn lower average incomes than the rest of Mexico, rendering the relative cost of birth registration higher and often inaccessible. Communities with high infant mortality and poverty rates often question the economic 'investment' in registration when the survival of the child is largely uncertain (Mercado and Ortiz 2014: 19-20). Other explanations for late or no birth registrations in Chiapas can include geographic isolation and the accessibility of registration offices (time, economic cost, distance, transport factors); parental misinformation, unwillingness or inability (ie. a parent's lack of records with the state makes them ineligible to register their children); mismatches between literacy and language skills of the state registries and peoples, especially of indigenous and Afrodescent; existence of communities where birth registration with the state has no place and ancestral customs/ institutions are primordial; seasonal/circular and international migration (including whole families); prejudice and discrimination around 'illegitimate' births, gender, race, religion, politics and so on (Mercado and Ortiz 2014: 19-20; Harbitz and del Carmen Tamargo 2009). Economic barriers to birth registration grow stronger over time as well because Mexican authorities impose fines for untimely birth registries (Mercado and Ortiz 2014). 
I highlight the fact of the non-registration of local chiapanecos for two reasons. First of all, because as the years pass, unregistered or poorly registered children grow into adults. The problem of non-registration becomes even more complex, as factors compound and the stakes grow higher. An adult who does not have their birth registered with the state cannot participate in the formal labour market; open a bank account or access credit; pay taxes which fund public offices and infrastructure; inherit or formally own property; go to school or a hospital; marry or register their own children's births; they cannot obtain a driver's licence, vote or be voted for in any level of state electoral process and so on (Mercado and Ortiz 2014). Persons whose birth has not been registered also cannot obtain national identity cards, passports or travel visas for stateauthorized movement.

Secondly, having large proportions of local populations 'unregistered' in a given territory poses a governmental challenge for states because rule of law requires the identification and registration of populations in order to act (in particular ways) as a technology of governance. Thus, the greater the unregistered populations, the greater necessity there likely is to develop hybrid, grey, or alternative systems of governance. This would include, among others, alternative systems for directly taxing the 'informal' or 'unregistered' production, consumption, and movements of populations. With this latter point, one might think of international trafficking networks, but also authorities' use of extortion and other illicit or informal means of policing more localized, mundane mobilities, including intra and inter-municipal mobilities.

Authorities working in diverse public institutions throughout Mexico are known to use their authority to charge or to negotiate an extra-official fee when providing a public service. This practice can be found in many of the state institutions in Mexico, but it is particularly pronounced among police and customs officials in their regulation of diverse forms of mobilities. 
Local authorities working at key transit points throughout the Mexican republic regularly use extortion and other illicit and informal practices as means of policing more local, mundane mobilities, including intra and inter-municipal mobilities, as well as broader scale, international mobilities. This practice by which some police have historically used their authority to extract fees and objects of value from diverse mobilities, including migrants, is popularly referred to as paying 'la mordida' or 'cooperando para el refresco,' ('paying a bribe' or 'chipping in to buy them a drink').

Alvarado and Silva (2011), for instance, recently conducted a series of surveys to gain greater understanding of the relationship between police and the local population in Mexico City and the neighbouring city of Nezahualcóyotl. Though a very different context from southern Mexico, the results are illuminating: Of the 1297 respondents surveyed about their interactions with police, $22.5 \%$, or 292 responded that they had either been asked for la mordida or they had offered one during their interactions with police (p. 465). The researchers found that las mordidas most commonly arose when the possible sanction was a fine -justifiable or not- whose terms of payment was then negotiated or bartered over. Forty percent (40\%) of mordida cases reported in this study stemmed from interactions with police for transit violations or accidents; another $21 \%$ stemmed from police detentions on suspicion or traffic check stops; another $20 \%$ were related to administrative violations; and 20\% involved other diverse situations (Alvarado and Silva 2011). In sixty percent of the mordida cases involving traffic or administrative violations, the police official was reported as the one to ask for the mordida (Alvarado and Silva 2011: 465).

Until 2008, unauthorized entry and unregistered transit through Mexican territory was still considered a crime that was punishable with up to two years in prison and a fine of between 
300 and 5,000 pesos (approximately $\$ 30-\$ 500$ ) (Grupo Coppan 2008) $)^{50}$. Thus, by definition of this law, both local and international migrants who the Beta Groups were tasked with protecting were, technically-speaking, engaged in criminal activities according to national law. Though rarely enforced in this manner, Article 123 of the Ley General de Población, was regularly utilized by state authorities to extort money from unauthorized migrants as they passed through Mexico (González-Murphy and Koslowski 2011; Grupo Coppan 2008). In the 1990s, this practice increased with the introduction and strengthening of migration controls, which, with financial and logistical support from the United States, increased Mexico's rates of detention and deportation rates in its southern border region. These measures concentrated primarily on policing the highways running South to North from the Guatemala border to the Tehuantepec Isthmus.

\section{Unsettlement III: The United States}

During the late 1990s, a third group of people began to augment the number of passengers attempting to move through southern Mexico without economic means to do so: Deportees. Their growing presence and significance in the region were the product of the 1996 Illegal Immigration Reform and Immigrant Responsibility Act (IIRIRA), a legislative reform which was passed in the United States to purge the country of its unauthorized residents with utmost efficiency. ${ }^{51}$ This Act fundamentally redefined the conditions under which deportations of unauthorized residents could be ordered, contested, and carried out in the United States (Coutin 2007: 20). Along with the 1996 Anti-terrorism and Effective Death Penalty Act

\footnotetext{
${ }^{50}$ This law was modified in 2008, effectively decriminalizing unauthorized entries and stays in Mexico. Now, this is only considered to be an administrative offence, punishable with a fine that is equivalent to between 20 and 100 days of minimum wage (Grupo Coppan 2008).

${ }^{51}$ IIRIA - Illegal Immigration and Immigrant Responsibility Act- went into effect in April 1997
} 
(AEDPA), IIRIRA retroactively broadened the range of criminal convictions for which authorized and unauthorized non-citizen residents became eligible for deportation; it introduced mandatory detentions for those in processes of removal (deportation), and it expedited removals by eliminating judicial reviews and waivers that might prolong or contest a deportation order (Coutin 2007: 20). As a result, criminal convictions for relatively minor offences, such as shoplifting and public intoxication, suddenly became the bases for deportations- even when crimes had been committed and penalized prior to 1996; the number of migrant incarcerations and removals increased dramatically, as did the political and numeric significance of those residents marked as 'criminal removals' (Hagan, Eschbach and Rodríguez 2008: 64-66; Coutin 2007: 20). The 2001 USA Patriot Act further facilitated provisions for detentions and removals of non-citizens considered security threats (Hagan et al. 2008: 65).

As a consequence, this reform expulsed hundreds of thousands of hard-working, noncriminal residents who had fled to the U.S during the wars of the 1980s but had never managed to obtain asylum; it also uprooted a number of violent, street gangs, such as the MaraSalvatrucha and Barrio 18, and it injected them into Central America and southern Mexico. Consequently, these gangs transnationalized their membership and their illicit activities; among these activities were the recruitment and systematic extortion of migrants who used the railways to transit through Mexico to the United States. 
As Table B illustrates below, following the passage of IIRIRA, the total number of removals of migrants from United States doubled in just a few short years, rising from 69,680 in 1996 to 188,467 in 2000 . By 2005 , the total number of removals had practically quadrupled compared to 1996 levels, reaching 246,431 (DHS 2013). While these numbers are staggering, they are even more so when one considers the manner in which US residents of Mexican and Central American were disproportionately represented among the 1.8 million people ${ }^{52}$ removed from the United States between 1996 and 2005.

Table 4- Total Number of Removals from the United States 1988-2005

\begin{tabular}{|l|l|l|l|}
\hline Year & Total removals & Year & Total removals \\
\hline 1988 & 25,829 & 1997 & 114,432 \\
\hline 1989 & 34,427 & 1998 & 174,813 \\
\hline 1990 & 30,039 & 1999 & 183,114 \\
\hline 1991 & 33,189 & 2000 & 188,467 \\
\hline 1992 & 43,671 & 2001 & 189,026 \\
\hline 1993 & 42,542 & 2002 & 165,168 \\
\hline 1994 & 45,674 & 2003 & 211,098 \\
\hline 1995 & 50,924 & 2004 & 240,665 \\
\hline 1996 & 69,680 & 2005 & 246,431 \\
\hline
\end{tabular}

Source: Department of Homeland Security. 2013 Yearbook of Immigration Statistics (Table 39; removals of inadmissible or deportable aliens out of United States based on an order of removal)

In the United States, post-IIRIRA deportations and dispossessions have been distinct from those in Mexico. While migrant detention practices often have, in some sense, targeted migrants on the move in the United States, since 1990s, many migrants have been detained on their way to work or to visit family and friends. A large number of those deported from the

\footnotetext{
52 Exact number deportees between 1996 and 2005 is 1,782,894. In 2012 and 2013, US deportations were higher still, reaching over 400,000 removals each year. In 2013, the total number of deportees since IIRIRA topped 4.7 million. Author's calculation based in numbers presented in DHS 2013 Yearbook of Immigration Statistics.
} 
United States in recent years have deep roots and personal histories in the country which, in some cases, span decades and represent whole lifetimes. The deportations have uprooted people, forcing them to leave behind houses, vehicles, family members, livelihoods and communities (Hagan et al 2008; Coutin 2007: 29-31). A random survey of 300 Salvadoran deportees found that more than a quarter of deportees had resided in the United States for 10 years or more, approximately $80 \%$ were gainfully employed, and $31 \%$ were living with a spouse and child at the time of their deportation (Hagan et al 2008: 72-75).

Having been separated from their livelihoods, and, often their loved ones, many of Central American and Mexican migrants deported since IIRIRA have had ample motivation to return to the United States as quickly as possible. One civil society organization in El Salvador estimates that between 40 and $60 \%$ of Salvadorans attempt to return to the US clandestinely following deportation (Coutin 2007: 38). Another survey of Salvadoran deportees confirms this estimate, finding that $38 \%$ of 300 deportees surveyed in El Salvador in the early 2000 s expressed plans to return to the United States while another 25\% remained undecided (Hagan et al 2008: 82). Nevertheless, the deportation process itself can also dispossess migrants of the few possessions they have on them at the time of detention, leaving them with few resources to move on from the cities to which they are deported, places where deportees rarely have social networks to support their return home in Mexico or the United States. For instance, a recent survey of 1,092 Mexicans deported from the United States between 2009 and 2012 found that, in 34\% of the cases, the possessions migrants were carrying at the time of apprehension were confiscated and not returned before deportation. Possessions included cash (averaging \$55USD), cell phones and identity cards, all of which, as the study noted, were necessary for accessing transport out of 
the city to which they had been deported and made deportees vulnerable to violence and exploitation upon arrival (Martínez and Slack 2013:1-6).

\section{Containment and Extraction}

In early 1989, Mexico began to articulate clear policy positions with regards to Central Americans in Mexico. This was the result of two factors: 1.) The December 1988 arrival of Mexican President Carlos Salinas de Gortari- whose political project for Mexico prioritized 'opening the country up' to the United States and fostering greater integration and cooperation with the neighbours to the north, and; 2.). The United States' move to extraterritorialize its migration control practices. In February 1989, the United States government rolled out 'Operation Hold the Line,' a border control program specifically designed to address and restrict unauthorized migration originating from Central America (Frelick 1991). Along the US-Mexico border, the operation increased border patrols, expedited asylum proceedings as well as the deportations of unsuccessful asylum applicants. These efforts were highly publicized in an effort to deter Central Americans from attempting the journey north; nevertheless, the operation's expansion of United States' Immigration and Naturalization Service (INS) operations into Mexican territory was largely kept under the radar (Frelick 1991).

Citing internal memos circulated by INS in 1988 and 1989, Frelick (1991) illustrates how, prior to commencing the operation, the INS planned to use their liaison "to slow down the flow of illegal aliens into the United States;" "Enhance Anti-smuggling presence and use of informants to develop information on organized trips;" "Request State Department to determine ways in which the Mexican and Central American governments can assist in efforts to ascertain scope of Central American migration to the United States," and; "Alert Mexican authorities of intention to increase enforcement efforts along the south Texas border" (Internal INS 
memorandum December 5, 1988 cited in Frelick 1991: 211) ${ }^{53}$. Ten weeks later, another internal report concerned with the INS operation's 'Enhancement Plan for the Southern Border,' discussed plans to post the following US officials in Guatemala City and Tecún Umán (Guatemala-Mexico border town): two US intelligence officers, two Border Patrol Agents, two Anti-Smuggling Agents and an Immigration Officer from Mexico City District Office for Operation Hold the Line. In addition, the report detailed plans for INS Officers to be duty-posted in Mexico City, and another three officers to be posted to northern Mexico's city of Monterrey (Enhancement Plan for the Southern Border, INS report, February 16, 1989, pp. 16-18 cited in Frelick 1991: 212). According to this report, the purpose of these postings was to collect intelligence "...on smuggling patterns and alien movement through their areas of jurisdiction," which, in conjunction with information garnered from migrants detained in INS operations along the US-Mexico border, would allow US authorities to anticipate and restrict the movement of Central Americans before they reached the United States border (ibid). By late February 1989, internal memoranda sent from the district director of INS in Mexico City to the INS Central Office provided "detailed intelligence on movements of undocumented aliens in Mexico; they revealed the extensive involvement of the INS in Mexico, as well as the high-level cooperation with Mexican Immigration Services ${ }^{54}$ " (Frelick 1991:212).

Operation Hold the Line not only established INS-intelligence gathering activities in Mexico and Guatemala, however; it also successfully recruited the Mexican government to set up migration check points along its transit corridors and to deport Central American migrants

\footnotetext{
${ }^{53}$ While Operation Hold the Line has, with time, come to be understood in terms of this latter intention to build up border patrol along the south Texas fringe, a project which INS brought to fruition in September 1993, Frelick 1991 provides the evidence showing a much broader time frame and geographical scope.

${ }^{54}$ Dirección General de Servicios Migratorios (DGSM)
} 
before they reached the United States border (Frelick 1991). Motivated by the prospect of a free trade agreement with the United States, Mexican authorities began a diligent campaign of detainment and deportation of Central American migrants (Casillas 1991). As a result, Mexico's deportations rose from just 13,000 in 1988, to 70,000 in 1989, and 126,440 in 1990 (Casillas $1991: 72)^{55}$

Table 5- Evolution of Migrant Detentions \& Deportations from MeXico 1988- 2005

\begin{tabular}{|c|c|c|c|}
\hline Date & $\begin{array}{c}\text { Total volume of } \\
\text { detentions and deportations }\end{array}$ & Date & $\begin{array}{c}\text { Total volume of } \\
\text { detentions and deportations }\end{array}$ \\
\hline 1988 & 13,000 & 1997 & 85,588 \\
\hline 1989 & 70,000 & 1998 & 11,572 \\
\hline 1990 & 126,440 & 1999 & 126,498 \\
\hline 1991 & 133,342 & 2000 & 172,935 \\
\hline 1992 & 123,046 & 2001 & 152,412 \\
\hline 1993 & 122,005 & 2002 & 138,061 \\
\hline 1994 & 113,115 & 2003 & 187,614 \\
\hline 1995 & 105,940 & 2004 & 215,695 \\
\hline 1996 & 107,118 & 2005 & 240,269 \\
\hline
\end{tabular}

Sources: Casillas 1991; Casillas 2007

Building on the success of Operation Hold the Line, in 1990, the United States began to reimburse Mexico for the cost of Central American deportations, thereby establishing an economic incentive, as well as a longer-term arrangement between the two countries (Aragonés 2011). In addition, in July 1990, the Mexican government reformed its Ley General de Población'- General Population Law- to recognize asylum seekers fleeing generalized contexts of violence (García 2006: 76-77). Likely because of the underground railway and sanctuary movement which emerged in Mexico and the southern United States in the 1980s to help Central

\footnotetext{
${ }^{55}$ Frelick (1991) confirms the dramatic increase in migrant detentions and deportations in Mexico between 1988 and 1991 but offers slightly different numbers from those of Casillas (1991 and 2007). Based on interview data with US and Mexican government officials, Frelick asserts that the detained and deported numbered 14,000 in $1988,85,000$ in 1989, 80,000 in 1990, and was projected to reach roughly 160,000 for 1991 (Frelick 1991:210).
} 
Americans find safety, the law also imposed ten-year prison sentences and fines on anyone helping to shelter or transport non-nationals through Mexican territory (García 2006:77).

Throughout the 1990s, detentions and deportations from Mexico averaged approximately 130,000 migrants per year, an estimated $95 \%$ of which were nationals from the Northern Triangle countries of Central America: 46\% Guatemalan, 24\% Salvadoran, and 25\% Honduran (Casillas 2007:18). These numbers grew further between 2001 and 2005 with the introduction of Plan Sur, a federal migration control policy which further augmented available infrastructure for intercepting Central Americans in southern Mexico and preventing their transit north. With financial support from the United States, this plan strengthened existing migration checkpoints in southern Mexico by constructing two additional control 'belts' across the territory between the Gulf and Pacific Coasts. One belt ran through the states of Oaxaca, Veracruz and Tabasco along the Tehuantepec Isthmus, and another belt ran just north of the towns of Mapastepec and Palenque in Chiapas, and Frontera in Tabasco (Casillas 2007:21).

\section{Checkpoints, Madrinas and Mordidas}

With the aforementioned measures in place, Mexican deportations carried out between 1988 and 2005 largely targeted transit routes in order to intercept people as they moved through the southern region of Mexico toward some northerly location (they were already uprooted). In the early 1990s, these focused mainly on the Pacific Coast Highway- where there are three permanent checkpoints (retenes) -El Manguito, El Hueyate and Arriaga- and floating checkpoints which could pop up at and surprise unsuspecting migrants at any point on route.' There were also patrols at train stations where, on July 23, 1992, for instance, a Guatemalan man and two Salvadoran men were detained for deportation in the Tapachula train station (El Orbe 1992). And there were surprise checkpoints along the railway. 
Before the 1980s, persons in transit could be asked for mordidas by any number of Mexican authorities who might detain them (migratory services, federal judicial police, and municipal police) along the transit routes These were often relatively small dispossessions in the broader scheme of things, they nonetheless had broader implications for migrants who had taken debts and sold properties in order to make the journey in the first place. One informant for this study affirmed that the payment of mordidas is independent of whether you have papers or not. The only difference between those with and without have papers is that those with papers pay less. Those without papers or money are taken for review to see if it is really true that they are not carrying anything. If it is, they are put in jail and deported. Those who have money but no papers, however, and those who travel by bus, are given the possibility of paying to pass. He describes his experience passing through the state authorities' mordida system in southern Mexico in 1980:

I left El Salvador by bus...To get to Puebla, we had to pass through five or six checkpoints (casetas). And in each of these five or six checkpoints, they asked for 10 pesos, 15 pesos; or, if they didn't ask for 15 pesos, it was for a drink, or a soda- 'para las aguas.' It wasn't as difficult for us because we were travelling with a visa, but it doesn't matter. In Mexico, it doesn't matter if you have papers or not. You have to pay. Do you understand? You have to pay money to continue on your way. If not, you cannot... (Interview 10, author's translation).

In Mexico, the figure who often demands the extra-official tax from persons in transit is popularly known as a 'madrina,' an unofficial state official who works together with state authorities along transit routes throughout Mexico. The term madrina is a play on words to refer to "civilians [who] help the authorities as a madrina, or godmother, would and [who] administer 
madrizas, or savage beatings (Nazario 2006: 74). One informant for this study spoke to the role of madrinas in charging mordidas on transit routes in Mexico:

There are even people who are not police officials. They are called madrinas...they are not agents, but they run errands for the agents....and these are worse than the police (judiciales) because they think they are something that they are not....The officials are there giving orders to the madrinas, that is, they are sitting in the shade, in their cars, in their trucks, listening to music. And they get these guys - who are not officials or anything- to charge and rob [a soriarse] - under the table, and to do everything that they cannot do because they are officials and the madrinas are not. They [madrinas] are people who practically sell themselves....and it is practically learning to rob. They think that, because they put on a uniform and are accompanied by a state official that there is no problem (Interview 10)

As migration controls and deportations grew during the late-1980s and early 1990s, detentions at checkpoints intensified and involved ever greater-dispossessions and greater incidences of deportation to Guatemala (García 2006: 67; Frelick 1991: 232). The problem became so acute that, in 1987, Tapachula's newspaper El Diario del Sur carried the headline "'Madrinas' from the Federal Judicial Police Extort Tourists" ('Madrinas' de PJF extorsionan a turistas.)" and explained:

Even though the General Office of the Republic (Procuraduria General de la República) decided some time ago to formally remove candidates who aspire to join the Federal Judicial Police -commonly referred to as 'madrinas' or soplones- from the ranks of this corporation in this city, the Federal Judicial Police continues to use this type of pseudopolice to do dirty work, such as extorting people who engage in illicit activities or who 
are considered outside the of the law. The 'madrinas' sometimes accompany an agent who is working and extort riferos, boliteros etc. who are then forced to hand over large quantities of money in order to avoid detention and torture.... But it is unspeakable what the madrinas of the PJE are doing to Central American tourists ${ }^{56}$ who visit us. In any checkpoint (garita) that they pass through, Central American visitors must give them one quetzal per head to get to Tapachula, even when they have their migratory documents in order. These pseudo-police officials who do this take home between 350 and 400 thousand pesos per day without much work. It is important to note that in this type of extorsion we are not including those from food inspection (Sanidad Vegetal), or those from immigration (Servicios Migratorios), or those who 'work' independently at their own risk. Many foreign tourists have complained and return to their countries speaking horribly about the way they are treated by the authorities. The PGR should investigate and take the appropriate measures (pp. 1 and 8).

This newspaper article in El Diario del Sur is just one of many which, in the 1980s and early 1990s, criticized a wide array of Mexican state officials for their extorsion of Central Americans travelling through the southern border region (see, for instance, El Diario del Sur 1983, 1985, and 1990). As we will see in the following chapter, the open criticism of the mordida and madrina system, along with pressures relating to NAFTA, lead to the mordida system being passed on (somewhat formally although not completely) to non-state criminal actors, such as the Mara Salvatrucha and the Zetas drug cartel. It also stimulated the migration of a range of state

\footnotetext{
${ }^{56}$ It is interesting to note the language in this newspaper. Before the La Bestia had come into force in southern Mexico, Central Americans in the Soconusco were regularly referred to as 'tourists,' likely because of the importance of the local cross-border commerce to the Tapachula economy. In the course of my research, I asked many informants about Central American tourists in southern Mexico, and all of them told me that they didn't exist. That is to say, what people understand as a tourist today appears to be very different from that which was understood to be a tourist in the early 1990s.
} 
and non-state actors- Beta Groups and Scalabrinian missionaries, for instance- offering protections to migrants on La Bestia.

\section{Railway as a Space of Escape}

Deportation policies in the United States appear to have generated circular patterns of migration in the Central-North American region (Hagan et al 2008: 85). ${ }^{57}$ Because, until 2008, the Mexican Constitution allowed for expedited deportations, non-nationals were detained and then placed in a regular jail cell and bussed over the southern border to Tecun Umán, Guatemala, regardless of their country of origin. This practice of dropping deportees on the other side of the Río Suchiate without money often left deportees with more incentive to attempt to another crossing into Mexico than to return home, generating high-intensity circular patterns of movement back and forth over the Guatemala-Mexico border (García 2006: 68-69). This practice was later partially remedied when deportation buses leaving Mexico began to make the trek to Honduran and Salvadoran borders to drop off deportees.

In this chapter, I venture the hypothesis that, at the turn of the century, and particularly following the implementation of Plan Sur, these circular migratory patterns were particularly accentuated in southern Mexico because of the strategic importance this space had acquired for the interception of migrants in transit to the United States. Furthermore, because the process of deportation not only forcibly un/settles people, but also dispossesses them of the economic means to access transport, most deportees begin their long journeys back north without funds. Thus, a second hypothesis ventured here is that deportees circulating through southern Mexico

\footnotetext{
${ }^{57}$ The rise of deportations is not restricted to the United States only. Rather this practice has grown steadily since the mid-1990s in other parts of the world as well. See Gibney 2008 for a discussion of this phenomenon in the United Kingdom.
} 
have fewer economic resources to formally access modes of transport through, for instance, ticket purchases.

During the 1990s and early 2000s, the migrants who had money could pay bribes, purchase false documents, travel by air and bus without much worry. As earlier discussions in this chapter illustrated, however, the unsettled were most often dispossessed of their belongings. Because of the jurisdictional fissures and tortuguismo of Ferrocarril Panamericano, it became the logical channel to move outside of capitalist and state structures which governed the means of movement. It was a source of escape, not only from the state authorities, but also from payment required for movement.

As Chapter 3 noted, the opening Mexico's national railways to private operations -but not ownership- generated jurisdictional nebulousness and bickering (which continues to this day) with respect to the division of responsibilities regarding security on the Chiapas and Mayab Railways in southern Mexico (Ureste and Ángel 2016). The security 'gap' or fissure which these actions created in the infrastructure space offered an opportunity for anyone who did not have state-issued identity or visa documents to transit North through the region, thereby avoiding the growing number of migration controls on the highways in southern Mexico at that time. They therefore generated a space for the un/settled to move and be governed outside of state laws.

Secondly, the privatization of railway service (Chapter 3) brought about the gradual elimination of railway passenger services, which, though less important in other parts of Mexico, continued to provide a vital source of transportation in southern Mexico, a relatively marginalized region with regards to transport infrastructure. Finally, the slow speed which had earned the Panamericano Railway the nickname El Tren de-Mora- (Chapter 2) was very same 
reason that migrants were able to board and ride the train despite the elimination of passenger services.

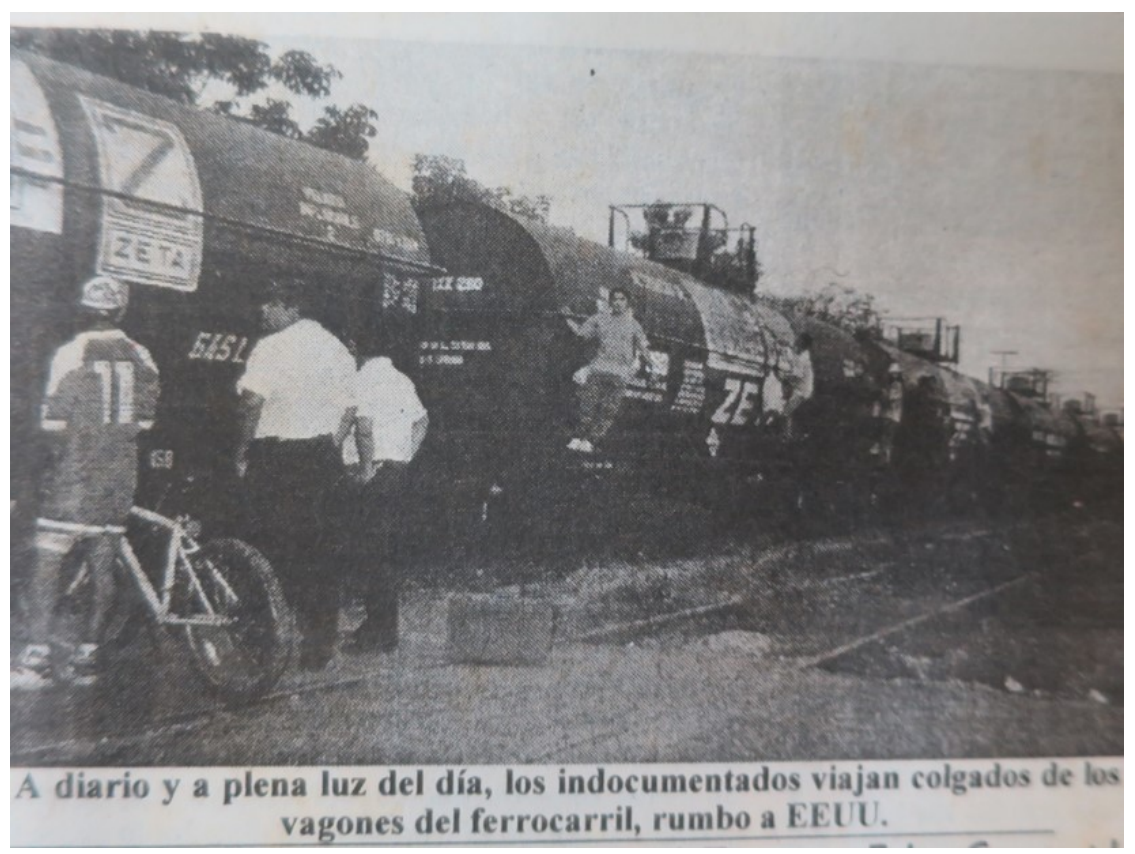

FiguRE 17- EARLy OCCUPANTS OF LA BESTIA

Image Caption: Everyday, under the light of day, the undocumented travel toward the United States hanging from railway cars (Author's Translation)

Source: Sánchez Martínez, Jesús. 1996. “Auge el Tráfico de Indocumentados en la Frontera Sur.” El Orbe Año XIX, No. 5419. 18 de enero. Front page.

Within this context, migrants and deportees began riding atop the box cars of mixed cargo-passenger trains of the Panamericano. In the early years, there were a number of advantages to riding the freight trains. On one hand, riding the freight cars provided a tactical and economic advantage given the migration control context. In the past, if one could learn enough social cues and knowledge to blend into the sea of local railway passengers and avoid being picked out of a crowd by Mexican authorities, this scenario was less threatening. But luck and knowledge had to be on one's side (Interview 13). No longer able to 'blend in' or stowaway 
in a hidden compartment for 1 or 2, migrants and deportees were forced to draw on both their numerical mass and their visual exposure as tactical advantages which could offer distinct probabilities, vistas and routes for escape ${ }^{58}$.

In 2000, buses travelling north through southern Mexico encountered up to nine migration checkpoints; buses, by virtue of being a closed vehicle, offered no means of escape when detained. With the freight trains, there was a possibility of escape. The slow movement of the train and the openness of cargo travel created strategic advantages for migrants. As the trains slow for revision, migrants were able to jump off, run away, lie in wait, and re-board the same train or another when these begin moving again (Nazario 2006: 62). One resident who grew up in a community adjacent to the Panamericano recalls state railway raids during the early 2000s:

In my town, I remember seeing many large operatives with groups of police, migration authorities and different police agencies. They would park alongside the train tracks with the lights blaring (torretas encendidas) and they conducted migrant hunts...the patrol cars were placed on either side of the train tracks about 50 metres before the train station. When the train arrived, agents would pull them off; some migrants would run from the authorities. To a certain extent, this transmitted the message to local residents that, because they were migrants, they were illegals, delinquents and assailants. So what did we do? We would close our doors because there were delinquents who the police were trying to catch...People [migrants] ran in one direction and another, trying to escape from police. So you would close your door because there were the delinquents. So, all this encouraged the situation that, today, people still believe that being a migrant is

\footnotetext{
${ }^{58}$ This tactic is similar to that employed by migrants in Tijuana or Calais who no longer hide, but rather 'rush the fence' as a means of overwhelming authorities and offering at least a few migrants the chance to get by each time.
} 
synonymous with being a delinquent or a being marero $^{59}$ or the worst. They believe that the worst comes from Central America. So, even though there has been a lot of work to improve the image of the migrant population, there are other factors that work against this project. If you read a newspaper from around here, you will find terrifying news about migrants. They will always highlight in large letters the person's origin as Honduran, Salvadoran, Guatemalan or Central American. So, this encourages all this (Interview 9).

The railway lines, which were originally constructed to connect points of Mexican agricultural production to points of North American consumption, now offer a compass for disoriented populations travelling North without money or a map. Again, not any kind of migrant arrives on the rail. Today, it is the unsettled migrant, uprooted and dispossessed by a renewed impetus toward regional integration which necessitates the distinction between Mexicans and Central Americans.

\section{Concluding Remarks}

In mainstream media, reports on La Bestia refuse to tell the stories of expulsion and deportation whose origins (not destinations) are the U.S. They do not highlight the expulsion and relocation of undocumented peoples in the US as part of the 'migration crisis' in Mexico. As a result, no direct lines are drawn between 'purge and surge' of migrants in Mexico, that is, we do not see the injection of deportees into Central America and southern Mexico as directly related to the rise in volumes of 'migrants' captured and expelled in the north. We do not see how deportations work together with security perimeters to both contain and feed the transit

\footnotetext{
${ }^{59}$ Member of the Mara Salvatrucha gang
} 
migrant population, creating the illusion that ever-greater waves of migrants threatening to overwhelm/ drown North America.

As a result, stories and images of La Bestia easily lead one to believe that millions of Central Americas are heading to the United States in uni-directional and unstoppable fashion. Mainwaring and Brigden (2016) have noted that the representation of migration flows as a unidirectional, unceasing line is a political act, which participates in the securitization of the migrant politics. It creates the illusion of a regional invasion from the outside, and it unwittingly feeds the very same national security crises and xenophobia it was originally designed to combat. In part, the reason that we do not see this has to do with the tendency to treat migration as something separate and unrelated to other movements (humans, symbols and objects) which inhabit the same mobilities field. Migration studies are often conducted in isolation from deportation studies as though they were two separate phenomena (see Gibney 2008 and Blue 2015 for exceptions) $)^{60}$.

This chapter has offered a counter-memory to trouble 'growing exodus' accounts of migration. It suggests that more attention be paid to the ways in which deportations and extraterritorialized migration control practices of the global North can work together to generate dense, circular migration flows in limited spaces. This, I contend, produces a visual effect which supports narratives of a 'growing exodus' and restrictions on movement. In making this argument, I do not mean to diminish or deny the gravity of circumstances which force migrants to flee economically or politically violent contexts. Rather, I wish to lighten the weight of classic

\footnotetext{
60 Ethan Blue (2015), for instance, does contemplate some of the ways in which deportation and migration are inter-connected and overlapping. For instance, he notes the possibility that island detention centres which served to capture migrants (physically and administratively) as they arrived in the United States also served to immobilize those who were being expelled. Blue also makes connections between migration and deportation in his reflections on the circular movement of deportees who choose to return to the United States following expulsion.
} 
theoretical understandings of migration which take for granted that it is the poor and violent countries of the global South which expel and dispossess migrants, and it is the unproblematic countries of the global North which they are drawn to. 


\section{Chapter 5 - The Politics of Protection}

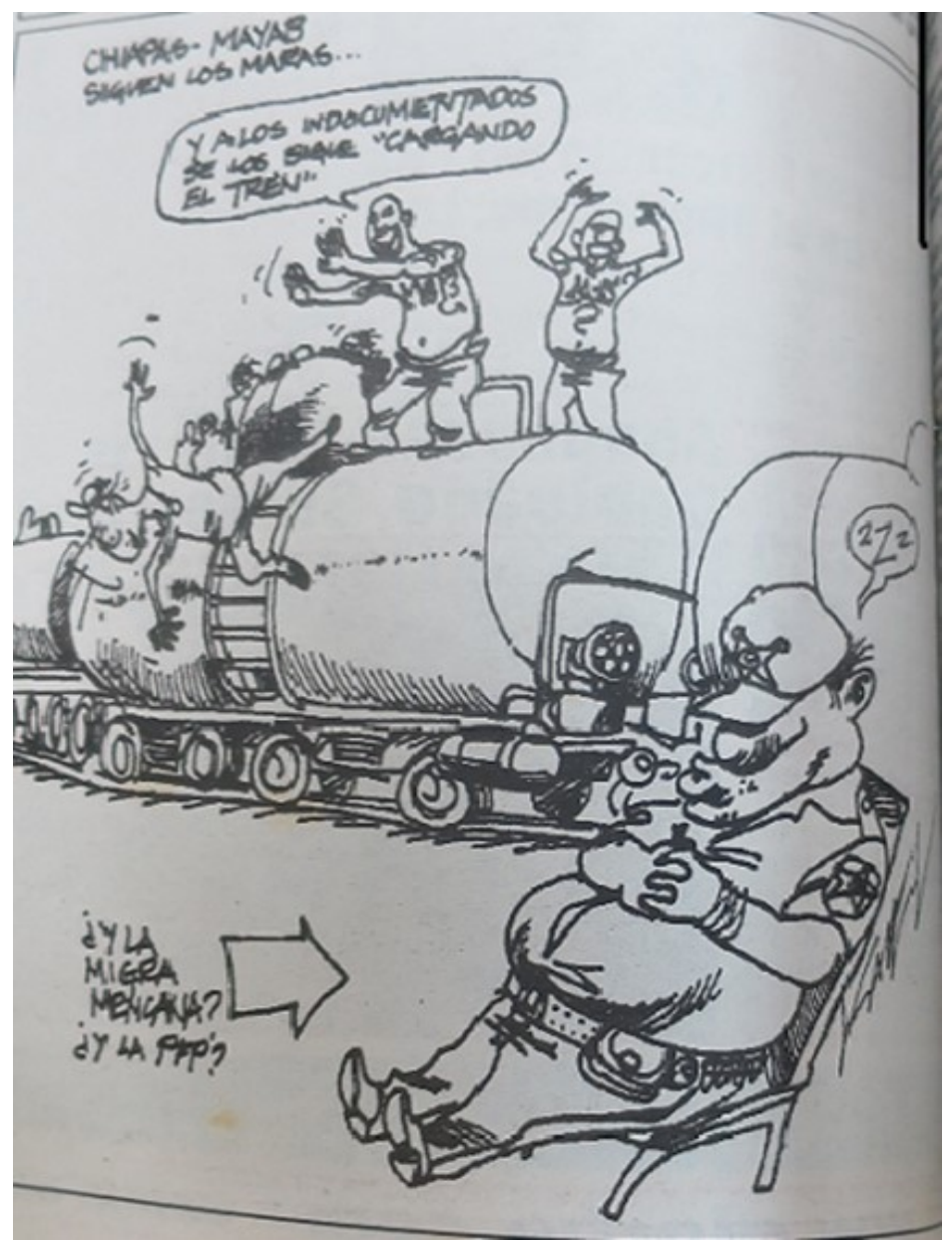

Figure 18 Maras And MigRants On LA BESTIA

Source: El Orbe. 23 febrero 2005. p.2

As more and more migrants began to travel on top of the freight trains of the Ferrocarril Panamericano, more and more actors became interested in capturing these populations.

Additional state authorities, missionaries, organized criminals, international non-governmental actors, and journalists all arrived in southern Mexico during the late 1990s to intervene in transit migrations in some manner. In this counter-memory, I set aside perilous stories of transit migration journeys, and, instead, I turn our attention to another migration phenomenon which has 
received much less attention: The settlement of state and non-state actors who migrated to southern Mexico during the 1990s to intervene in the movement of transit migrants on La Bestia

Though apparently quite diverse, these actors share many similarities in regard to their origin, rationales and practices. The actors who migrated during this period all belonged to institutions which were first established in the North (United States and in North or Central regions of Mexico). As such, the arrival of these actors in southern Mexico suggests an extension of these networks into the region, and a twenty-first century mode of colonization. Secondly, they intervened in transit migrations with the same rationale: Protection. This commonality, I argue must be understood in relation to processes which have already been discussed in this dissertation. Indeed, because the railway restructuring had generated the jurisdictional fissures and gaps in 'security' and an escape route for transit migrants (chapters 3 and 4), this stimulated an active battle for a monopoly on the means of movement (Torpey 2000) along the Panamericano (known now as the Chiapas Railway), and, the Mayab Railways in southern Mexico.

Finally, all these actors utilized similar technologies to facilitate transit migrations. They used patrols to collect data on these mobile populations; moreover, they all used safe houses and passwords to move people.$^{61}$ There is one practice, however, which differentiates these actors from one another -but also builds connections among them- and that is the use of direct violence

${ }^{61}$ Data on the most recent practices of charging piso on the train, stems from interviews with key informants in southern Mexico. The analysis the migration and settlement of Beta Groups stems from a close reading of their 1996-98 field journals of the Beta Group 'Sur', which operated between the Tapachula and Pijijiapán in the southern state of Chiapas. 
to tax movement. In this chapter, I analyze the migration of just one of these actors: Mexico's Grupos Beta de Protección al Migrante, or Beta Groups.

\section{The Birth of the Beta Groups}

Authorities working at key transit points throughout the Mexican republic have long used their authority to extract fees and objects of value from passersby, regardless of their migration status. As we saw in Chapter 4, this practice is popularly referred to as paying 'la mordida' or 'cooperando para el refresco,' ('paying a bribe' or 'chipping in to buy a drink'). With the initial murmuring of a North American Free Trade Agreement (NAFTA), state authorities' long-standing practice of charging mordidas on transit routes throughout Mexico became politicized in the late 1980s, leading to the creation of Mexico's Grupos Beta de Protección al Migrante, or the Beta Groups on the U.S. -Mexico border. This happened first along the U.S.- Mexico border.

In the early 1980s, the Tijuana-San Diego corridor was a booming border crossing for hundreds of thousands of Mexicans seeking economic reprieve from the 1982-peso crisis and for growing numbers of Central Americans seeking political refuge in the United States. Then, in 1986 the United States signed the Immigration Reform and Control Act (IRCA) into law. This act aimed to drastically reduce, if not eliminate, ungoverned populations in the United States through three main gestures: 1.) By offering amnesty to millions of unauthorized migrants who had arrived in the United States prior to 1982; 2.) Increasing border control budgets and efforts to keep out ungoverned population, and 3.) Beginning mass deportations of unauthorized migrants, particularly those of Mexican and Central American origin. As a result, IRCA simultaneously strengthened U.S. sovereignty while growing Tijuana's population of unauthorized migrants-in-waiting by deporting Mexican and Central Americans to this border city and making it more difficult to enter the United States. 
Within this context, the Tijuana-San Diego border crossing became a corridor that was notorious for generalized violence and lawlessness, and migrants were a regular target of diverse crimes (Nevins 2002). Mexican and U.S. police working in the border zone did little about the dynamic, either participating in the illegal activities themselves, turning a blind eye or keeping a safe distance. Meanwhile, civil society groups on both sides of the U.S- Mexico border regularly highlighted the high rate of human rights violations in the area, demanding something be done. In June 1990, a new Border Patrol Chief named Gustavo de la Viña arrived in the San Diego. Perturbed by the number of rapes, assaults and killings of migrant workers on the U.S. side of the border at the hands of bandits from Tijuana, de la Viña ordered that the chain link fence which marked the US-Mexico boundary at the time be replaced by a steel border wall (Nevins 2002: 99). In addition to erecting the wall, de la Viña also reached out to the local Mexican consulate to ask for police support to fight border bandits on the Mexican side of the border (Nevins 2002: 101).

With negotiations beginning for the North American Free Trade Agreement (NAFTA), Mexico was under pressure to demonstrate to its neighbours to the north that it was capable of providing free-trade corridors- such as the Tijuana-San Diego crossing- that were secure and corruption-free (Specht 2009; McDonald and Paromchik 1996). Thus, in late 1990, Mexico's federal government disbanded its Border Inspection Group on account of corruption, and it created the Tijuana Beta Group to collaborate with San Diego Border Patrol in their fight against border crime, particularly that which targeted migrants (Nevins 2002: 101; McDonald and Paromchik 1996: np). 
Informally-known as Operativo Bandido (OIM 2011a), the Tijuana Beta Group was a federal pilot program founded by Mexico's Interior Ministry (SEGOB) ${ }^{62}$. During its first months and years of existence, it was described by newspapers as an "an elite Mexican police unit" (Rotella 1993a), and "a relatively new, multi-agency border force made up of federal, state and city officers who are charged specifically with protecting migrants from crime" (Rotella 1992a). The Tijuana Beta Group was considered an elite police force in that its officials were "specially selected from other Mexican police agencies...better paid and better trained than many of their counterparts. They report[ed] directly to Mexico's interior minister, who report[ed] to President Carlos Salinas de Gortari” (Rotella 1993a). They also had a zero-tolerance policy on breaches of

In order to protect migrants from crime, Tijuana Beta officials dressed in plain clothes so as to blend in with migrants, infiltrate groups and arrest people caught in the act of committing any one of a broad range of crimes from public drunkenness to car theft, to people and drug smuggling, extortion, and even rape and murder (Specht 2009; Rotella 1992a). Officials were armed and given sole jurisdiction over the Tijuana border zone in order to prevent clashes with other Mexican police officials working in the area (Specht 2009), and they worked in close collaboration with San Diego's Border Crime Intervention Unit (Rotella 1993a). This crimefighting activity was described by Javier Valenzuela Malagon ${ }^{63}$, founder and initial head of Tijuana Beta Group, as central to the group's fundamental mission, which was the "protection of the migrant" (Rotella 1992a).

\footnotetext{
62 Although INM claims to have founded Grupos Beta in 1990, the INM itself only came into existence in 1993. It was actually SEGOB which initiated the pilot project and later passed on its administration to INM.

${ }^{63}$ Trained as a psychologist and a former university professor, Javier Valenzuela Malagón was the brains behind the creation of Beta Groups, as well as the director of the founding Tijuana group during its first few years.
} 
The positive results rendered by the Tijuana Beta Group led politicians and migrants' rights advocates in Mexico and United States to call for an expansion of the program to "other border hot spots" (Rotella 1992b), a call which was most certainly heeded. During the decade following the inauguration of this pilot project, a series of similar protection groups emerged at other strategic points along Mexico's border with the United States under different names (OIM 2011a). In 1994, the Nogales Beta Group was created, and then, in 1995, the Beta Groups were formalized through agreements and two more groups were created: Alfa Group in Tecate and the Ébano Group in Matamoros (INM 2001a; INM 2012; OIM 2011a) ${ }^{64}$.

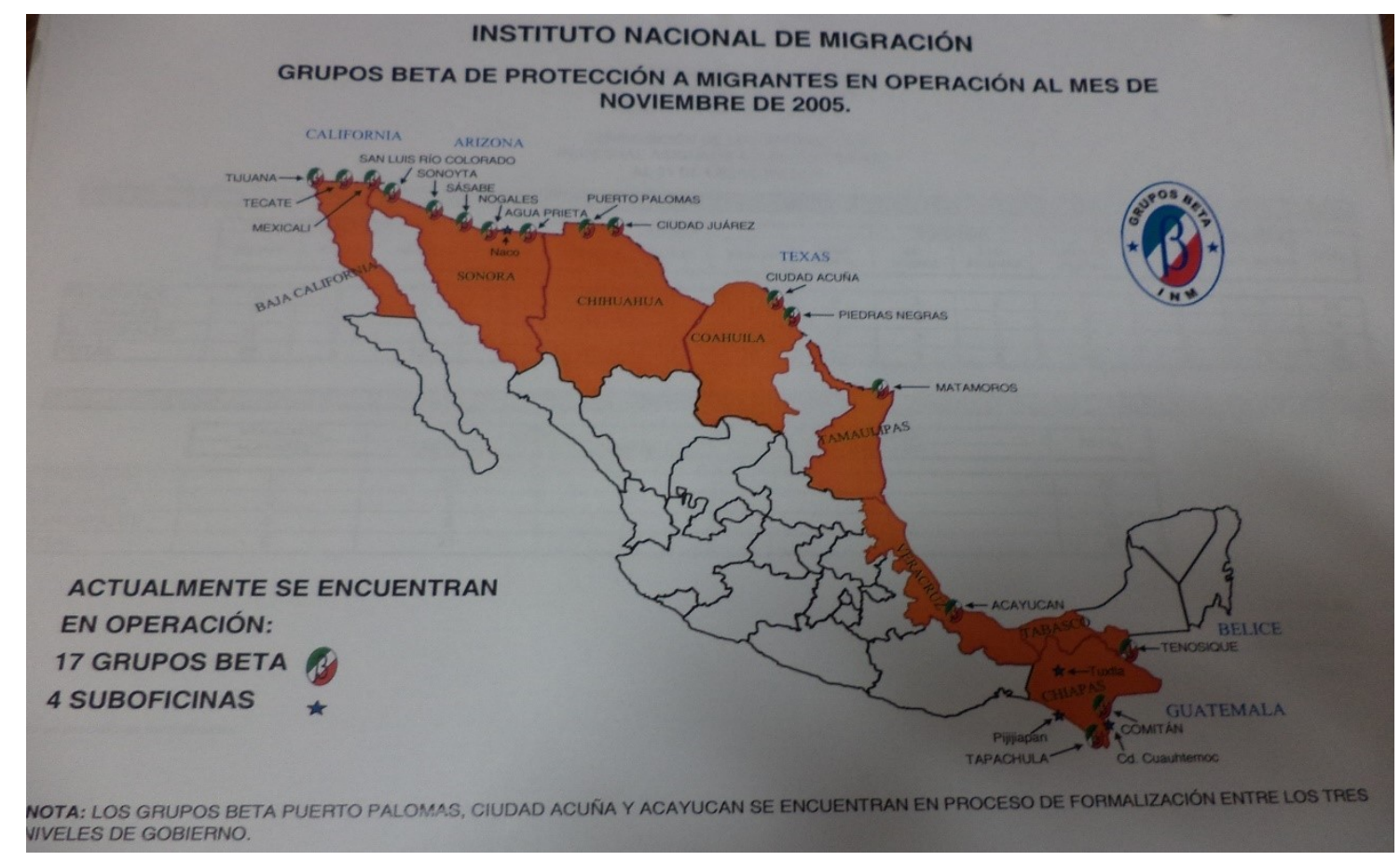

Figure 19- MAP Of THE BetA Groups’ Operations IN 2005

Source: Instituto Nacional de Migración (INM-SEGOB). 2005. "Grupos Beta de Protección a Migrante 2005.” Biblioteca de la Unidad de Política Migratoria, INM- SEGOB. México, D.F.

\footnotetext{
${ }^{64}$ Nogales, Tecate and Matamoros are the names of towns and cities found along the U.S- Mexico border.
} 


\section{Migration and Settlement}

In 1996, groups were created in Agua Prieta, Sonora and Tapachula, Chiapas, the latter of which responded to recommendations made by Mexico's National Commission for Human Rights $(\mathrm{CNDH})$ to address widespread human rights violations in southern Mexico (INM1998c; INM 2001a). When Beta Group Sur arrived in southern Mexico in May 1996, their stated aim was “...to protect the human rights, and the physical and patrimonial integrity of migrants, regardless of their nationality or migratory status, through actions which inhibit and prevent the aggressions and abuses which are committed against them by criminals and dishonest authorities" (INM 1997, author's translation). In order to do this, they needed to: 1.) Identify migrant populations and spaces, and; 2.) To differentiate between the 'undergoverned' and 'ungovernable' spaces and populations. This was no easy feat for a number of reasons.

Much like what had happened in Tijuana a decade earlier, the late 1990s saw the convergence of several migration phenomena in this region of southern Mexico. As we saw in Chapter 4, during the late 1990s, there was a decline in the international market prices for key agricultural commodities, such as coffee and fruit, which led many chiapanecos (persons originating from Mexico's southern state of Chiapas) to join Central Americans on their international journeys to the United States (Nevins 2007). At the same time, there was also an increase in the number of Central American migrants journeying through Mexico to the US to find work and family members. This latter trend grew because of the devastation which Hurricane Mitch inflicted on Central America in 1998 and because of increases in deportations to Central America following the passage of the United States' Illegal Immigration and Immigrant 
Responsibility Act (IIRIA) in $1996 .{ }^{65}$ As we saw in Chapter 4, IIRIRA prioritized and retroactively broadened the range of criminal convictions for which permanent and unauthorized residents in the United States became eligible for deportation (Coutin 2007).

As a consequence, this reform expulsed hundreds of thousands of hard-working, noncriminal residents who had fled to the U.S during the wars of the 1980s but had never managed to obtain asylum; it also uprooted a number of violent, street gangs, such as the Mara Salvatrucha and Barrio 18, and it injected them into Central America and southern Mexico. Consequently, these gangs transnationalized their membership and their illicit activities; among these activities were the recruitment and systematic extortion of migrants who used the railways to transit through Mexico to the United States. Finally, as we saw in Chapter 4, the 1990s also saw the expansion of migration controls in southern Mexico, which had the effect also increasing state authorities' rates of extortion on transit routes- and particularly highways- in southern Mexico.

\section{Patrols and Human Inventories}

Beta Group Sur identified transit migrant populations and spaces primarily through the practice of regular foot and vehicle patrols that were designed to gather knowledge about the movement of migrants, and the crimes committed against them. According to one report, "The preventative foot patrol allows us to continuously come into contact with migrants since these are mandatory passage points (pasos obligados) on their way to the Central and Northern parts of the country" (INM 1998c). Patrols also offer the Beta agents a mobile means to "... register complaints, descriptions of their aggressors, the place time and circumstances of crimes," (INM 1998c, author's translation). Thus, much like the patrols of other police forces, Beta patrols

65 IIRIA - Illegal Immigration and Immigrant Responsibility Act- went into effect in April 1997 
involved the practice of gathering information and generating criminal profiles to develop crime fighting and prevention programing.

Nevertheless, unlike the patrols of other police forces in Mexico, the Beta's patrols were able to supersede the jurisdictional boundaries which ordinarily place spatial limitations on the authority of other police forces in Mexico. Because it was the international human rights framework which mandated part of the Beta's protection work, and because they were tasked to a certain extent with 'policing the other Mexican police' (a point I will come back to later on), Betas groups were able to design patrols which were flexible and responsive to the regular changes which characterize the movement of migrants and those who target them. As one report described it:

Depending on the general characteristics of the migratory flows in each locality; the incidence and patterns of crime detected, and; the human and material resources available, each month the group coordinator will determine the general parameters of the patrols, their operating hours, the configuration of groups of agents, the zones to be closely monitored, and the general operating strategies of the group. This can be modified at any moment, according to circumstance, to attend to changes in the circumstances (INM 1997, author's translation).

This ability to transgress the spatial boundaries of ordinary police jurisdictions is what allowed for the Beta Group Sur to reorient their patrols away from the policing of the state boundary dividing Cd. Hidalgo, Mexico and Tecun Umán, Guatemala and toward a more fluid and flexible policing of the railways. As one report noted, many months of unfruitful preventative patrols along Mexico's southern border led the Beta Group Sur to conclude that they needed to concentrate their activities along the railway tracks between the train stations of Cd. Hidalgo, Tapachula and Huixtla, since this is where the majority of crimes were committed against migrants 
(INM 1997). To adjust to the circumstances, the Beta Group Sur scheduled all its available agents to work a single shift which was dependent on the movement of the train. Agents were divided into two groups. One group conducted preventative patrols in a train station prior to and immediately after a train's departure. They asked anyone found around the railway to identify themselves, explain their motives and submit to police-style frisking to prove they were not carrying weapons which could be used to assault (INM 1997).

All Beta Group Sur officials operating within this context at the end of the 1990s were required to $\log$ all of the incidences of contact they had with migrants and their assailants while on preventative patrol (INM 1997, author's translation). Such incidences were to be recorded in a chronological and sequential manner, noting the day of the incidence, all of the participating Beta agents, and the lead of the Beta group on that particular shift (INM 1997, author's translation). Then, at the end of the day, Beta agents were required to write a report, summarizing: 1.) All detentions (consignaciones ante una autoridad), and the type of legal authority which they were channeled to, 2.) All cases of direct assistance to migrants, indicating the problem and the type of assistance that was provided, and; 3.) Any other significant event which occurred in the day (INM 1997, author's translation). Any incidents which were not reported carried consequences for the person guilty of omitting it in the daily report. (INM 1997, author's translation). The Beta group's patrol logs, and the daily and weekly activity reports which were developed from these, were delivered to diverse audiences, including: 1.) The Beta Group Sur's head office and the regional delegate of Mexico's National Migration Institute (INM) ${ }^{66}$. 2.) An interinstitutional technical

\footnotetext{
${ }^{66}$ The fact that the migrant protection practices of Beta Group Sur were so closely monitored suggests that this information likely also supported migration control efforts in southern Mexico during this period. This is because the regional delegate for the National Migration Institute was responsible for overseeing both the migrant protection and migrant control programs in that region of Mexico (need to verify this source). By requiring the Beta groups to document and communicate their interactions while patrolling migrants' transit routes, the regional delegate would have been able to utilize the migrant protection program as a means of police
} 
committee involved in the regular monitoring and evaluation of the Beta groups (a transparency initiative I will address in greater detail below), and; 3.) The Beta Group Sur Coordinator.

For the Coordinator, the daily and weekly reports were a means of systematizing and analyzing the data registered in patrol logs and tailoring the group's protection activities accordingly. As the excerpt below illustrates, two key migrant profiles- the 'victim' and the 'victimizer' resulted from early analyses of the patrol log data concerning the spaces and the behavioral patterns of diverse actors in transit routes in southern Mexico:

... patrols have allowed us to identify the social composition and the contexts (entorno) of the major crime scenes; to study the modus operandi of the criminal actors, and; learn about the migratory practices of the undocumented [migrants]. This has also allowed us to carry out operations (planes operativos) which are specific to the circumstances and causes which surround the victim-victimizer relationship (INM 1998c, author's translation).

These two figures -the victim and the victimizer- each carried their own characteristics, specific lexicon, migrant protection practices and indicators for measuring the protection outcomes. For example, the profile of the migrant 'victim' (actual and prospective) comprised those actors whom Beta agents encountered on their preventative patrols, but whose only criminal activity was their unregistered entry, stay or passage through Mexican territory. Here, the lack of registration or documentation is a defining characteristic of the migrant victim; they are also attributed with a sense of innocence which appears to stem, primarily, from an assumption of ignorance and marginalization, rather than maliciousness. In other words, the migrant victim was seen as 'undergoverrned,' and not ungovernable. As the following description illustrates, these

reconnaissance, which could have served to support migration control programs in locating migrants for detention and deportation. 
assumptions are clearly embedded in the 'social assistance' class of protection practices which Beta Groups engage in when encountering migrants who match this profile while on patrol. These practices are designed for:

...los indocumentados (undocumented ones) with whom we have direct contact, those we meet in their places of transit or provisional stay, to those whom we offer guidance-education (orientación) about human rights which they have while in Mexico; we give them the human rights pamphlet (cartilla guía); we receive their complaints, and we give them medical and food services when they require them, or social and juridical assistance when they accept or ask for it; we also alert them to the dangers and risks of particular areas; and we help prevent them from becoming involved in acts which could be considered criminal, or acts which alter our norms of social peace, convivencia (good neighbour), or which could affect the public peace. As a precautionary measure, we conduct body searches to ensure that assailants (asalta-migrantes) have not infiltrated among the migrants, or that no one is carrying any sort of arm which could be used in criminal acts. We take nationals and foreigners who we encounter altering the public order, under the influence of alcohol or some other stimulant, and present them to the administrative authority (INM 1998b).

Noteworthy in this passage here are the on-the-ground practices -particularly the body searches- used to distinguish the 'under/governed migrant victim' from their 'ungovernable migrant victimizers.' Furthermore, this attempt to sort, what one report called the 'true' from the 'harmful' migrants, is also apparent in the language which is used in the Beta reports written at this time (INM 1998b): The terms 'Migrante' (with a capital 'M') and 'Indocumentado' were used to refer to the migrant 'victims', whereas the 'victimizers' who were not recognized public 
authorities were referred to as 'persons,' 'gangs,' 'Maras,' and 'foreigners,' but never 'Migrantes' despite the fact that, by virtue of their countries of origin, many of the victimizers were in fact also migrants (INM 1997; INM 1998b; INM 1998c).

Victimizers of migrants were profiled according to their country of origin, as well as the frequency and the degree of organization with which they targeted the first group of 'Migrantes' for crimes. A report written in 1997, for example, described this profiling process in the following manner: “...we have started to identify these people who target migrants as members of different Mara gangs, and as all sorts of criminals of occasional and systematic, national and foreign character. (INM 1997, author's translation). Another report presented a statistical overview of Beta Group Sur's activities during their first 18 months of operations. Their description of the crime-fighting aspect of their work is revealing. They noted that, among those persons which Beta Group Sur had detained and turned over to administrative authorities while on patrols during this period:

52 in 1996 and 411 in 1997 were foreigners found to be violating 'Police and Good Government' bylaws (disposiciones), disturbing the peace or public order, generally while intoxicated or under the influence of some other stimulant, such as thinner, cement or marijuana. Overall, the majority of these were persons with irregular status, without an honest livelihood. They were identified as members of one of two gangs of foreigners Mara 13 and 18), who assault the indocumentados (undocumented), and who constitute, without any prejudice (sic.), a risk for Migrantes, and a latent danger for the border community (sociedad fronteriza). In terms of crime prevention, they constitute out greatest preoccupation given the antecedents and accusations (imputaciones) which are frequently attributed to them (INM 1998c, author's translation). 
Finally, it is also important to note the fact that the reports which I analyzed for this study clearly indicated the advanced development of profiles of the civilian victimizers which Beta agents interacted with while on preventative patrols. Nevertheless, there was a total underdevelopment, if not absence, of profiles for those victimizers who committed crimes against migrants while acting in their roles as public authorities, such as police and customs officers. This omission is significant if we consider that crimes committed against migrants by public authorities were well-documented by the Beta Group Sur, and that they were explicitly highlighted in their initial mission statements (INM 1997 and 1998c). This contradiction is likely explained by the highly sensitive and dangerous nature which the task of 'policing other police' represents.

\section{Policing the Police and Other Governmental Dilemmas}

The patrols and logs were not only used to identify, differentiate, and engage the transit migrant populations. They were also used to address the ungovernable state authorities. In particular, they were mobilized: 1.) To deter, arrest, and support the prosecution of other police and state officials' victimization of migrants, and; 2.) To monitor the integrity and transparency of the Beta group in order to prevent it from becoming 'ungovernable,' and to ensure its strict adherence to rule of law. Let's look at each use of this knowledge in greater detail and their implication for the exercise of sovereign power in Mexico.

In the first six months of operations, Beta Group Sur registered an average of 40 cases of extortion or robbery of migrants, with $41 \%$ of these attributed to public authorities, and the other $59 \%$ attributed to local criminal activity (INM 1998c) ${ }^{67}$. The Beta Group's patrols along migrant

\footnotetext{
${ }^{67}$ This proportion of migrant complaints against Mexican authorities in the south was a relatively larger than that which was registered by the Tijuana Beta Group. During the month of November 1994, for instance, this group found that, $23.1 \%$ of crimes committed among migrants in the Tijuana area were attributed to Mexican officials; $7.7 \%$ to US officials, $53.8 \%$ to common criminals, and $15.4 \%$ to unknown persons. Some $61.5 \%$ of migrants' complaints were for assault; $23.1 \%$ for extortion; $7.7 \%$ for kidnapping, and; $7.7 \%$ for other crimes (INM 1994).
} 
transit routes and in migrant detention facilities were thus intended to deter public authorities in these spaces from committing crimes against migrants; their presence was also to meant to ensure that that justice -rather than impunity- was served when crimes were committed against migrants, as Beta groups were to accompany and protect the migrant victims through the process of filing a judicial complaint. As mentioned earlier in this paper, the Beta Groups were originally meant to be corruption-proof police force which, during the negotiation of NAFTA, would offer evidence of Mexico's ability to 'secure' or to protect the diverse mobilities which circulate within its borders, and to ensure that these were governed according to a rule of law, that is, according to rules which were harmonized and enforced equally throughout the region. In order to achieve this, however, the Beta groups faced to two challenges: 1.) How to ensure that this police force would be different from the rest? (ie. combating the ungovernable) and, once this was achieved; 2.) How to convince others that this was in fact the case? (ie. public image/ legitimacy of authority)

In order to ensure that the Beta Groups started out and remained in their role as the 'good cops,' a series of checks and balances were built into the selection/recruitment, training, compensation, and monitoring methods used to compose and regulate the force. These included recruitment of Beta agents from different jurisdictional levels of policing- municipal, state, and federal; higher pay; more comprehensive training, particularly in the area of human rights. Beta agents were required to participate in continuous training, which offered regular capacity-building in three thematic areas: 1.) Human rights and state-level offices, 2.) Local juridical frameworks for combating crime, and; 3.) Police tactics and physical fitness (INM 1997, author's translation). In March and April 1997, for instance, Beta agents received a total of 16 days of 8 hour training sessions, which included 7 days of "Jiu Jitsu, Security and Submission techniques (medidas de seguridad y sometimiento), and arms training," a 2-day workshop entitled "Human rights, the rape 
and sexual abuse of migrant women and children," and a 7-day workshop in which the UNHCR, along with Mexico's National Migration Institute (INM), COMAR and National Human Rights Commission, trained agents in the national and international legal frameworks for migrants and refugees in Mexico (INM 1997, author's translation). With this training, Beta agents were tasked with mobilizing these knowledges and techniques in order to protect migrants from crime.

Internally, there were procedural guidelines which were designed to police the Beta agents 'from within.' Such guidelines included strictly forbidding agents from engaging “...in activities which differ from those which are legally ascribed to them" (INM 1997, author's translation); the guidelines clearly prohibited anyone who was not a Beta agent from accompanying them on their patrols without express consent from the Regional Delegate. This included journalists and other types of police units (INM 1997, author's translation). Beta agents were prohibited from using anything that had been confiscated in an arrest (vehicles, drugs, arms), and they were required to turn such items over to the authority along with the person who had been porting it (INM 1997, author's translation). Beta agents were also prohibited from using any personal belongings which have been acquired illegally (INM 1997, author's translation). They were required to “...always wear uniforms when carrying out their work, given the preventative and dissuasive nature of crimefighting" (INM 1997, author's translation). Beta agents were only permitted to work undercover (without uniform) for special operations, which the Regional Delegate knows about and which are designed to detain criminals who are clearly identified and located" (INM 1997, author's translation).Finally, beginning in June 1998, Beta Group Sur began rotating the agents working in supervisory role; they also engaged in a self-evaluation process by which the Beta agents themselves came together to assess their successes and failures and to discuss the possible solutions to the challenges they faced on the job (INM 1998b). 
There were external mechanisms in place as well, which were designed to keep the Beta groups honest. As discussed in the previous section, Beta agents were required to log all of their activities and interactions when on preventative patrols. The coordinator of the Beta Group Sur was required to submit regular bi-monthly and bi-annual reports to an interinstitutional committee for their review and comments by actors from academia, civil society, international organizations, and public offices (INM 1998b, authors translation). This mechanism was a product of the interinstitutional agreement signed on May 4, 1996 (INM 1998a).

The second problem which Beta groups faced was the dual-faced challenge of legitimacy/authority and public image, that is, how to convince others that they were in fact different from other police forces. This meant a lot of public relations to gain the trust of migrants and other actors mistrustful of the authorities. It also meant establishing authority which would be respected by other police forces in Mexico. The Beta reports which I studied alluded to these tensions and the challenges which this aspect of their work posed in terms of Beta group's morale, but also in very practical terms of logistics, as the Betas were relatively weaker in institutional size, influence, and material resources. For instance, one report included a (rather pessimistic!) cheer which Beta agents had developed in a team and morale building workshop. The lyrics of 'The Beta Cheer' are revealing: "Beta Sur. At the Service of Society. Beta Sur. With honour and dignity. I am police. Beta Sur. I am Police. Beta Sur. Who stops us? Nobody stops us. Who criticizes us? Everybody criticizes us. And if Death happens to surprise us while on duty? Welcome it will be" (Grupo Dos de Beta Sur, INM 1998b, author's translation) ${ }^{68}$.

\footnotetext{
68 "Porra Beta." Beta Sur. Al servicio de la sociedad. Beta Sur. Con honor and dignity. Soy policía. Beta Sur. Soy policía. Beta Sur. ¿Quién nos detiene? Nadie nos detiene. ¿Quién nos critica? Todos nos critican. ¿Y si en servicio la muerte nos llegara a sorprender? Bienvenida sea. (Grupo Dos, 25 de abril de 1998; original published in INM 1998b)
} 


\section{Post data. From Policing Patrols to Search and Rescue Brigades}

Efforts to ensure that the Beta and other police forces acted exclusively according to rule of law ultimately failed. At the end of the 1990s, reports of migrants being harassed, extorted and trafficked by Beta Groups and other INM agents came to light in different parts of Mexico, including in Tapachula (INM 1998c; INM 2001a). Then, to make matters worse, in 2000, a Mexican television crew recorded two officials in the Matamoros Beta Group watching passively as two migrants drowned in the Rio Grande. The agents, who were quickly dismissed, said they did not know how to swim (Puente 2001; Crosswalk 2001). This public scandal further damaged the already deteriorated image of the Beta Groups. Now, they were not only being accused of corruption, but also incompetence. Critics clamoured: How could Mexico demand respect for its migrants' rights in the United States, when it was incapable of guaranteeing protections for migrants in its own territory?

In an effort to purge the INM and Beta Groups of their increasingly tarnished reputations, in $2001^{69}$, Mexico's federal government announced a number of measures, including: Over 500 personnel changes within the INM; more than 70 officials under criminal charges or investigation, and more than 1,800 others charged with different immigration smuggling offenses. The Commissioner of Mexico's National Migration Institute -Felipe de Jesus Preciado- described these changes to journalists at that time as a "war that will be thorough" (Puente 2001). As one INM report indicates, changes to migration policy introduced by the newly-elected President Vicente Fox also motivated a complete overhaul of Mexico's Beta Groups in 2001:

\footnotetext{
${ }^{69}$ It might seem common sense and intuitive to attribute this shift in humanitarian government of migrants in Mexico to the change in world politics which followed the events of 9/11 in the United States. And, yet, in the case of Mexico, this would, on some be a mistake. As the May 2001, INM report cited in this paper demonstrates, the changes to Beta Groups were proposed and implemented prior to the events of September $11^{\text {th }}$ (INM 2001).
} 
Given the cases documented along the Northern border of migrants that have fallen victim to drowning, accidents and climatic conditions- particularly in winter and summer- and those registered in the mountainous and desert regions, in the canyons and fast-moving rivers, we have decided to transform the protection functions of the Mexican state. The aim s to strengthen and adjust these functions according to the new legal frameworks (disposiciones legales), circumstances and challenges in our country. The migration-related challenges which President Fox has committed to addressing, particularly those concerned with the protection and defense of the human rights of migrants, lead us to new direct actions with regards to the migrant, particularly in regards to social and institutional actions... (INM 2001a, author's translation).

In effect, the changes were quite dramatic. The newly-elected Vicente Fox disarmed all Beta Groups in the country, essentially transforming them from a police unit into a search and rescue squad. Beta Groups were reduced in size and number; they received new uniforms, with bright orange T-shirts, and their trucks were painted orange in order to make them more readily identifiable to the public, and; new agents no longer came from other police forces, and they were trained in legal and social assistance, as well as first aid and search and rescue techniques (INM 2001a; Puente 2001). The orientation and social assistance materials which Beta Groups used to engage the ungoverned migrant victims (potential and actual) also shifted accordingly. As Figures 2 and 3 illustrate below, information given to migrants during their patrols (newly renamed 'search and rescue brigades' to divorce them from their policing origins) no longer focused on the risks or threats posed to migrants by criminal groups, but rather those risks related to the heat of the desert during the summertime or the dangers of riding atop freight trains (INM 2001b). 

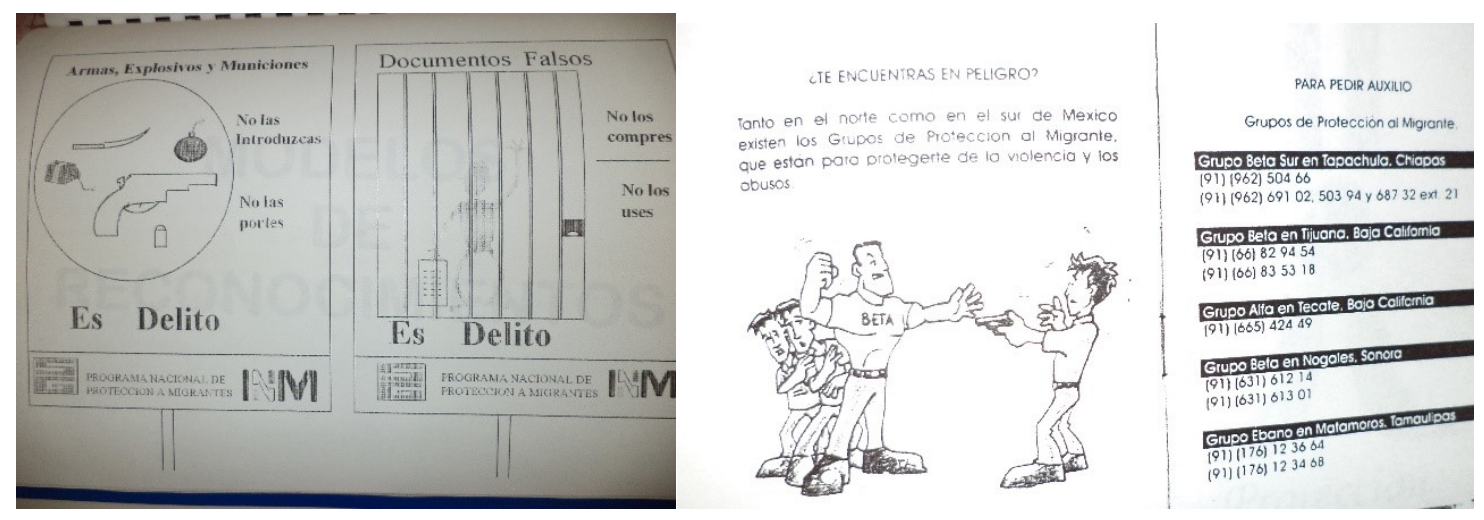

FIGURE 20- POSTERS AND PAMPHLETS USED FOR ORIENTATION OF 'MIGRANTES' AND 'INDOCUMENTADOS' DURING THE 1990S

Source: Poster on left INM1998b. Pamphlet on the right accessed at La Biblioteca de la Unidad de Política Migratoria, SEGOB, México, D.F.

The poster (left) Informs migrants that carrying false documents, arms or explosives is a criminal offence; Source: INM1998b; The pamphlet (right) says "Are you in danger? Migrant Protection Groups are present in both the North and South of Mexico to protect you from violence and abuses.” Source: La Biblioteca de la Unidad de Política Migratoria, SEGOB, México, D.F. (author's translations) 

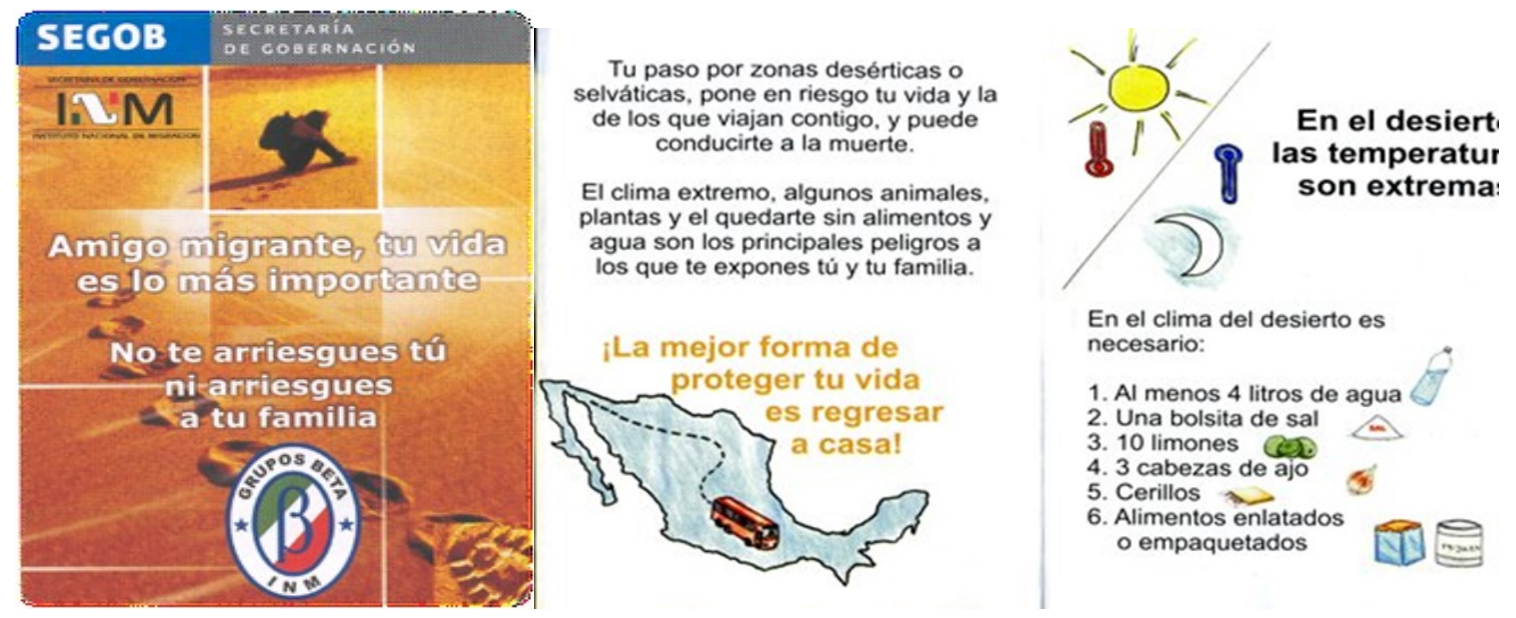

Figure 21 -POSTERS AND PAMPHLETS USED FOR ORIENTATION OF MIGRANTES FOLLOWING THE 2001 REFORM

The poster (left) reads "Migrant friend, your life is most important. Don't risk yourself or your family. Source: Reynoso Nuño 2010; On the pamphlet (right), migrants are informed of the dangers found in jungles and deserts. They offer a list of essential survival items, and the following piece of advice: "The best way to protect your life is to return home." (Author's translations) Source: pamphlet (right) http://webpages.scu.edu/ftp/fdugan/wall_mi.htm

Thus, in little more than a decade, Beta Groups had gone from being described as an 'elite police unit' to being presented as "a civilian agency whose charge includes thousands of migrants from Central America who travel through Mexico on their way to the United States" (Puente 2001). Strangely enough, despite changes in the practices of the Beta Groups, there was great continuity in the rationales for its existence. Leaders of the Beta Groups continued to present their mandate in the exact same manner: "The function of the Beta agents is to protect the migrants" (Jaime Pazdirector of the Matamoros Beta Groups in 2001, cited in Puente 2001). 
Likewise, Beta Groups continued to offer enormous political capital to the Mexican government in terms of Mexico- U.S. relations and domestic state-civil society relations Beta Groups' activities related to undocumented migration deterrence (originally by detaining human smugglers, and, later, by informing migrants of the dangers of border crossing and persuading them to go back) continued to demonstrate the Mexican government's willingness to cooperate with the United States in addressing this problem (Nevins 2002). Secondly, framing these activities as 'migrant protection' gave the Mexican government a way to respond to civil society's accusations of widespread human rights violations (ie. corrupt officials harassing migrants); to demonstrate to the international community that it was upholding its commitments to the migrant rights conventions it had ratified in the 1990s, and; to contest critics in the United States who pointed out the hypocrisy of advocating for Mexican migrants' rights in the U.S. while allowing Central American migrants to face myriad forms of violence as they transited through Mexican territory (INM 2001a).

Finally, the changes eliminated the contradictions, dilemmas (and perhaps also some opportunities) stemming from Beta Groups' condition as a police force whose job it was to enforce both national and international laws. As noted earlier, human rights were the raison d'etre of the Beta Group's efforts to stop and prevent crimes against migrants. Because the Beta groups' mandate stemmed in part from international human rights frameworks, it was possible to frame at least some of their humanitarian bordering practices in this way despite the fact that other practices- such as arrests- relied on national juridical tools. This presented enormous contradictions within this policing unit. One report submitted during the period of consultation and reflections for the 2001 redesign of the Beta Groups clearly outlines the contradictions and dilemmas which were involved in policing as the 'humanitarian arm' of Mexico's National Migration Institute: 
Experience demonstrated that the deviations (desviaciones) which penetrated and weakened the Beta institution occurred when we allowed their public security functions to absorb their duties, particularly with respect to combatting the trafficking of Indocumentados. This natural turn to privilege policing ended up distancing the Betas from their original aims and ideals, generating suspicions and doubts about their conduct...The preservation of Rule of Law (Estado de Derecho), without violating, and above all protecting, human rights, is an ideal which should be developed and practiced in all areas of the Institute. Nevertheless, it is a goal which is nearly impossible to reach if we pursue it through a hybrid agency, which, on one hand, searches for migrants to protect them, received their complaints and orders, and on the other hand, detains them for violating the law (INM 2001b, author's translation).

In short, while the humanitarian rationale and juridical frameworks remained important for the Beta's bordering of Mexico in the $21^{\text {st }}$ century, policing technologies and institutions were traded for socio-medical technologies and institutions. 'Migrants rescued' replaced 'criminal arrests' as an indicator of migrant protection efficacy (Reynoso Nuño 2010; INM 1998c). Detention centres gave way to hospitals and morgues as channels of state (re)integration. And undocumented migrants were increasingly framed as victims of their own poor decisions and a (depoliticized) set of environmental risks, rather than predatory, criminal groups.

By patrolling, the railways and generating juridical knowledge (focused on learning about and connecting transgressions of state law and human suffering/death) about the railway passengers, activities and spaces, Beta Groups came to constitute the railways of southern Mexico as a space of humanitarian governance. This fact is spatially significant because Mexico's railway system passes through the country's most remote corners. By humanitarianizing the governance of the railways, the Beta Groups in southern Mexico 
effectively opened up the possibility of re-bordering all of Mexico's territory so as to constitute it as one 'thick' humanitarian border and one 'strong' state.

\section{Chapter 6- The Politics of Representation}

A fellow carter...told him that Arriaga was the final stop he had to make with his wagon, and that there, in Arriaga, was the railway station. Andrés asked him what he meant, and the carter explained to him that there were giant freight cars which brought merchandise from afar so that it could be loaded onto their ox-drawn wagons and delivered around the country. He told him one more thing as well: he said that these cars were much larger than a wagon; they were as big as a stone house, and the contents of one could fill forty, even fifty wagons. The cars ran on steel wheels and more than forty of them could be pulled at once by another grander car which gave off a lot of smoke and snorted and sweat powerfully like a great beast; he said the name of all of this was the railway" (Traven 1949:36, author's translation). 


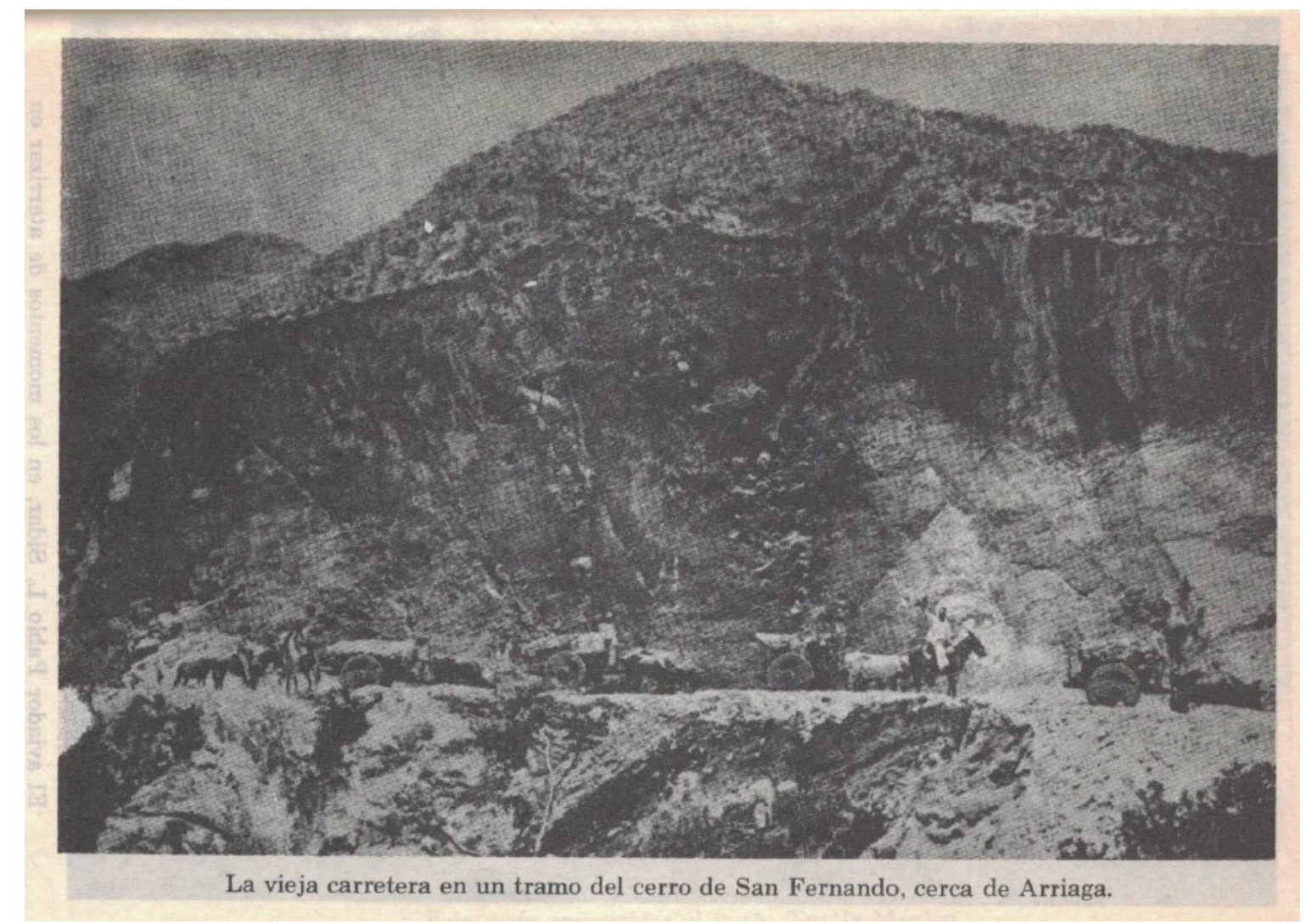

Figure 22- CARTers With BeAsts of Burden EN Route to ARriaga.

Source: Castañón Gamboa, Fernando. [1951] 1989. "Panorama histórico de las comunicaciones en

Chiapas.” In Lecturas Chiapanecas II, edited by Cuauhtémoc López Sánchez. Gobierno del Estado de Chiapas. Consejo Estatal para el Fomento a la Investigación y Difusión de la Cultura, No page number.

The selection, distribution, and presentation of visual and textual representations of infrastructure space are not neutral acts. They are political. Acts of power are encoded and circulated in media at the same time that media shapes the possibilities of political thought and action of their audiences (there are two audiences: of both migrants and non-migrants (McLagan and McKee 2012). As such, there is much to learn about migration and politics from the ways in which infrastructure is represented in the media and the ways in which these representations 
become politically useful instruments to different actors in the mobility politics field (see Walters $2010^{70}$ ). As Easterling (2014) argues, and as we saw in chapter 1, the "stories that a culture tells about infrastructure space can script the use of that space" (p. 89). Thus, interrogating how power shapes the creation and circulation of visual and cultural representations of infrastructure and its mobilities affects the political imagination and the uses of the infrastructure space opens an important window on the world of mobility politics.

This chapter traces the historical emergence of La Bestia, or The Beast that Devours Migrants, as a representation of the Panamericano. Counter to dominant narratives which in US and European media attribute the origins of this symbol to the migrants themselves, this countermemory traces its origins and transformation in the mobility politics of the United States. I argue that, over time, the diverse actors and processes have built the symbol of La Bestia, and they have used it as a tool for shaping or influencing the movement of peoples in southern Mexico and Central America. Such acts are consistent with the migration control and prevention efforts in other contexts (see, for instance, De Genova 2013; Andrijasevic 2007; Tyler 2006). The chapter ends by highlighting the less visible efforts of some groups to contest these beastly representations of the railway, the migrants and the communities these pass through.

\section{Building a Beast}

One of the multiple stories which together constitute the history of train we know as 'the Beast' might go something like this: The Beast was first introduced to mobility politics as a

\footnotetext{
${ }^{70}$ Walters (2015) argues that the transport vehicles and routes occupied by migrants on their journeys matter in the politics of mobility in at least two manners: 1.) As spaces or objects which have a representational role and an affect-evoking capacity in political struggles, and 2.) As micro-spaces of power relations and governmentality. Yet, as Walters points out, the academic literature concerned with the politics of mobility has tended to background the vehicles and routes in their analyses.
} 
result of a counter top conversation between two women in Los Angeles in the late 1990s. During this exchange, a housekeeper tells her female employer about the recent arrival of her son, whom she had left behind in Guatemala over a decade earlier in order to travel to the United States in search of work. The employer is a reporter for the Los Angeles Times, and the conversations she has with her housekeeper and long-lost son inspire a six-part investigative report on family separation and unaccompanied child migration to the United States.

In 2000, this reporter -Sonya Nazario- sets out to reconstruct the migrant journey of another boy she meets at the Nuevo Laredo border crossing. She interviews him at length and then tries to recreate the journey herself, meeting the people he interacted with, corroborating his story and learning how his journey was both ordinary and extraordinary. She rides the freight trains like he did. She hitches a ride on a trailer as he did. She tries to walk in his shoes to understand the odyssey. After two years, the project is published in 6 parts in fall $2002^{71}$ the Los Angeles Times. In 2003, the report-series and accompanying photos win the prestigious Pulitzer Prize, and, in 2006, the reports are expanded upon and published as the book Enrique's Journey. The book wins prize after prize. It is translated into eight different languages. It becomes standard reading on educational curriculums around the United States.

It was Nazario's work that first introduced 'The Beast' to North-Central American mobility politics. Nevertheless, the Beast did not debut as the demonic train so-oft described today, but rather as a reference to Mexico's southern state of Chiapas. Nazario dedicated a whole

\footnotetext{
71 The chapter 'Facing the Beast' is published for the first time in the Los Angeles Times on Oct. 2, 2002. See Nazario 2002 http://www.latimes.com/nation/immigration/la-fg-enriques-journey-chapter-three-notesstory.html\#page=1 as part of six-Part Series
} 
report/ chapter to the Chiapanecan portion of the migrant's journey. She entitled the chapter 'Facing the Beast,' and, in it, she described the perils of travelling through the state of Chiapas:

Painfully, Enrique, seventeen years old, has learned a lot about 'the beast.' In Chiapas, bandits will be out to rob him, police will try to shake him down, and street gangs might kill him. But he will take those risks, because he needs to find his mother (Nazario 2006: $61)$.

At the time of Nazario's research- and until 2005- the entire Pacific coast migrant route through the state of Chiapas could be done by $\operatorname{train}^{72}$, and so, by following in Enrique's footsteps, the whole narrative concerning this portion of the journey was concerned with riding the freight trains. As such, it is easy to see how the uncareful reader (and the broken telephone effect) could come to equate the state of Chiapas with the Panamericano railway. In addition, the narrative was illustrated by Don Barletti's award-winning photos, one of which shows three boys ducking under tree branches atop a freight train in Chiapas. The photo caption reads:

Migrants flatten themselves to avoid being hit by tree branches as their freight train rolls through Chiapas in southern Mexico. Enrique learned several lessons about the state known to immigrants as 'the beast.' Among them: Trust no one in authority, and never ride alone (Photo caption, 2006; N.P).

While the origins of 'The Beast' as a representation of the train rather than the state of Chiapas are commonly attributed to the migrants themselves, it is interesting to note that, despite her apparently thorough research, Nazario did not learn of this particular representation directly

\footnotetext{
72 In 2005, Hurricane Stan severely damaged the railway infrastructure along the Pacific Coast route through Chiapas. Migrants were no longer able to board the train at the Guatemala border with Chiapas and instead needed to travel on foot or by bus for over 200 kilometres along the Pacific Coast highway to the town of Arriaga. New tracks south of Arriaga have been rebuilt began their first runs in May 2014 (Gutiérrez 2014)
} 
from a migrant- in fact, her protagonist, Enrique, imagined the train as a powerful Iron Horse. Instead, it was an Italian priest in a migrant shelter who had told her about Chiapas' notoriety as a 'Beast' for its apparent lawlessness and mercilessness with migrants passing through (Nazario 2006: 270).

The Beast that debuted as the southern state of Chiapas in Nazario's 2002 work emerges again in 2005 in two different documentaries- De Nadie (Dirdamal 2005) and El Tren de la Muerte (Rocker 2005). These two films provide the earliest articulations of what is today a clear project concerned with North and Central American mobility politics. De Nadie, a film whose executive producer is Raul Vera, a major figure in the Catholic Episcopal Network lays out the problematic the viewer in unequivocal terms: For Central Americans to achieve their American Dreams, they must travel through Mexico. Mexico, according to the film is a nightmare for the Central American migrants who dare to realize their American Dreams. The film offers viewers an overview of the Mexican nightmare, a hell on earth created by a few key actors: "The Steel Beast" (La bestia de acero)-a cargo train that mutilates migrants who travel on it; "La Migra" (Los mata sueños/ the dream killers); "La Policia" (los ladrones con permiso/ thieves with authorization); La Mara (gangs that rob). The film offers a plethora of direct testimonies concerning the Mexican nightmare: railway employees, state officials, activists, academics and, most importantly, the testimonies of Central American migrants who have fallen victim to the trains, gangs, police or authorities.

El Tren de la muerte (Rocker 2005), or The Train of Death, was similarly infused with such themes, vacillating between hope and despair, life and death, and so on. This is illustrated in the manner in which the narrator explains the problem. The train ride, the narrator tells us, is a great adventure in the beginning. It is exciting. The migrants have heard much about it. There is 
palpable excitement. Suddenly, the film cuts to an interview with a migrant who had lost one of his limbs when he was thrown from the cargo train in an assault. They interview other migrants who have met with similar fates and the narrator tells us that every week there are new deaths and new patients. Furthermore, the narrator tells us that when these migrants recuperate from their injuries most will get back on the train of death which will supposedly take them to the United States $^{73}$ (Rocker 2005:11 mins). The sombre tone and shifts back to the excitement again. There folkloric music is now replaced by English tunes. We see a migrant riding a cargo train with a US flag in his hand. The narrator tells us that "the American Dream attracts them irresistibly, and the poverty rips them from their homes ${ }^{74 \text { " }}$ (Rocker 2005: 11:27 mins, author's translation). These scene of adventure, excitement and hope is followed by another of a migration raid on the train. The narrator speaks to the disappointment and then tells viewers that this is the cat and mouse that lasts months in Mexico. He observes: "They pursue a dream, and it repeats itself over and over as though the train were always moving forward but rarely arrives ${ }^{75}$, (Rocker 2005: 12:55mins, Author's translation).

Feeding the Beast: Capturing Stories, Images and Spaces

\footnotetext{
${ }^{73}$ Original text: "la mayoría persiste en el mismo sueño: volver abordar el mismo tren de la muerte que supuestamente los llevará a Estados Unidos"

${ }^{74}$ Original text: "el sueño Americano los atrae irresistiblemente, la pobreza les arranca de sus hogares..."

${ }^{75}$ Original text: "Persiguen un sueño que se repite como si fuera un tren que siempre está en camino y pocas veces llega"
} 


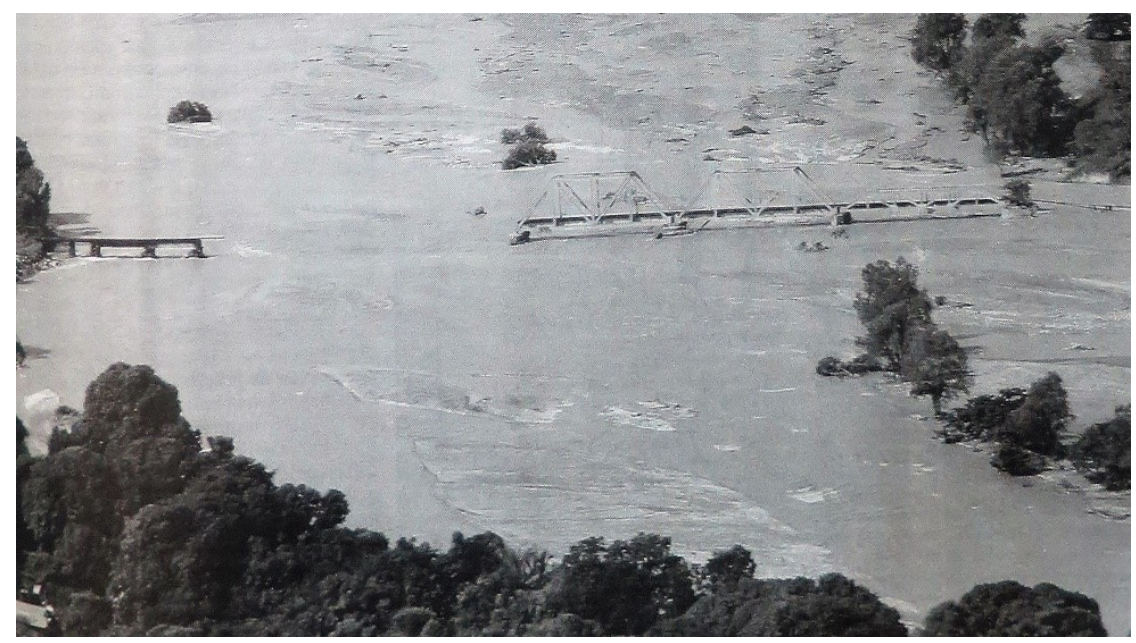

Figure 23- A Railway Bridge in Chiapas is Destroyed Following Hurricane Stan (2005) Source: El Orbe. 2005a. "Con daños severos 10 puentes ferroviarios.” 9 de octubre, p.43. Tapachula, Chiapas.

In 2006, Nazario's award-winning report series is published as the book, Enrique's Journey: The Story of a Boy's Dangerous Odyssey to Reunite with His Mother. This book wins similar accolades, and it inspires a whole army of actors - journalists, activists, church authorities, state authorities, migrants, artists, filmmakers and others from around the world (see, for instance, publications from Britain's BBC World and Spain's El Pais) to work tirelessly to update and expand upon her work. Her method of recreating or accompanying one or several migrants on their dangerous journeys through Mexico has now been utilized to produce countless films, books, photo and news reports (see, for instance, Cammisa 2009; Fukunaga 2009; Ultreras 2010 and 2012; Martinez 2010 and 2014; Silver and Garcia Bernal 2014; Quemada-Díaz 2013).

As a result, the first decade of the $21^{\text {st }}$ century saw a dramatic increase in the number of journalists on migrants' routes, as well as in the production and transmission of images and 
testimonies of migrants travelling by freight train through Mexico. The arrival of foreigners asking about $\mathrm{La}$ Bestia became so naturalized that, in one interview conducted for this study, a local reflected on the fact that the railway has always drawn people from around the world, but this time its mediatic mode of attracting people to the Soconusco was very different.

At around this time, migrants' route selection shifted when, in October 2005, Hurricane Stan devastated the Panamericano, demolishing bridges and washing away rails.

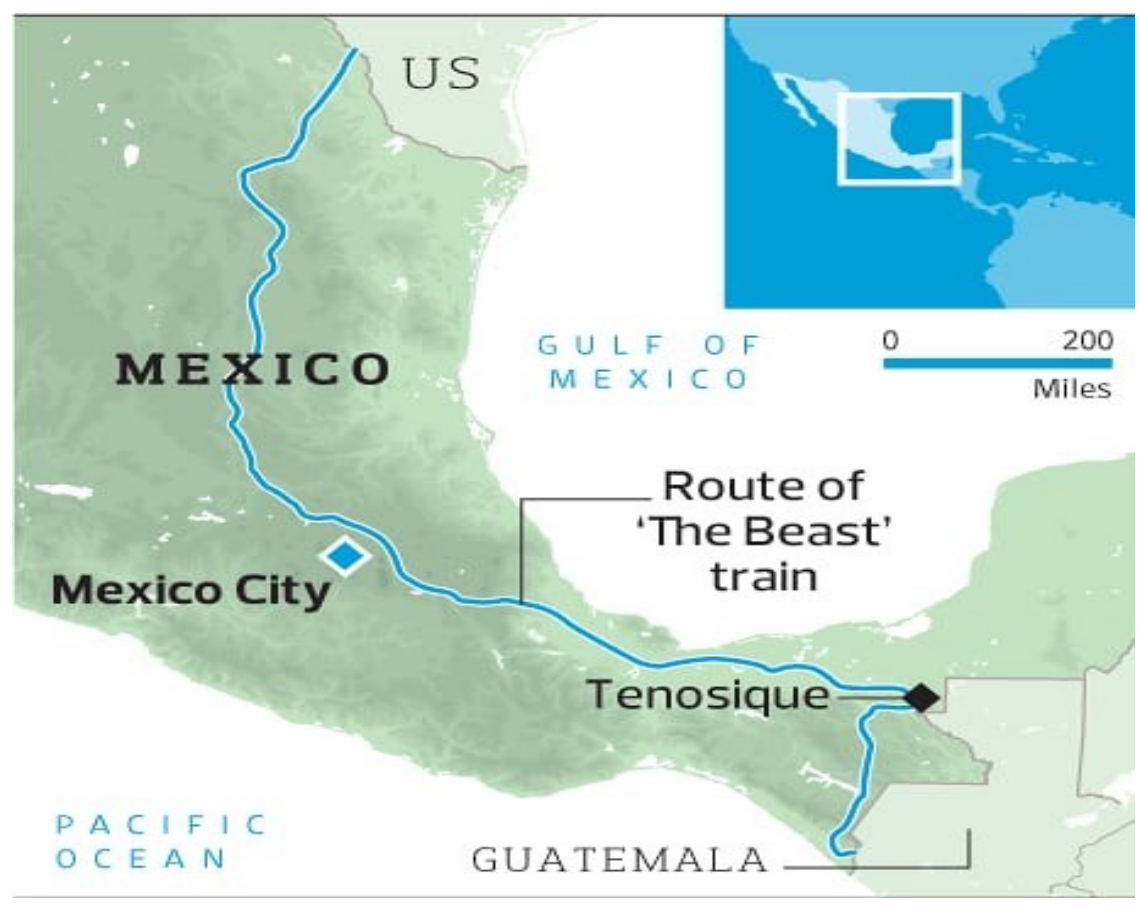

Figure 24 Route of 'the Beast' Train EXPands to the Gulf CoAst

Source: The Guardian. 2014. "Migrants Risk Life and Limb to Reach the US on Train Known as the Beast." The Guardian, August 23. Retrieved October 10, 2018

(https://www.theguardian.com/world/2014/aug/23/migrants-mexico-train-the-beast-fleeing-poverty) 
With the railway lines demolished between the Guatemala border and the Arriaga station along the Pacific Coast, migrants wishing to travel north through Mexico to the United States were left with two options. The first was to travel from the Guatemala border to Arriaga, either by foot, or by VW kombi (mini-bus/van), or taxi, utilizing Panamerican Highway and the remains of the Panamericano as their guides and compasses. The second option was to switch railways, instead, hitching a ride on the cargo trains which ran along the Gulf Coast of Mexico. This second option was attractive because it was the shorter land route through Mexicoparticularly for those leaving homes on the Caribbean coasts on Honduras and Nicaragua. Few options for transport infrastructure and dense, humid jungle which characterized the GuatemalaMexico border on the Gulf Coast, however, represented initial deterrents for would-be travellers. Later, the rise of organized criminal groups in this region also became a major concern.

Nevertheless, migrants began to favour the Mayab Railway along the Gulf Coast as a route to get to the United States, and, in doing so, they made it possible to represent other railway spaces in Mexico as the Beast. In other words, migrants' presence on the railways of the Gulf Coast - and their practice of riding atop freight cars- expanded the infrastructure space denominated as the Beast. Thus, Hurricane Stan had a dispersal effect on migration flows and a proliferating effect on the symbol of La Bestia. Now, the Beast could be anywhere there was a railway in Mexico, opening more spaces to engage in the politics of protection and state-making.

\section{Harnessing the Beast}

In 2014, amidst a 'child migrant crisis' on United States' southern border, a popular song called La Bestia was being played on radio stations across Central America. The song told the story of 'the Beast from the South...the wretched train of death' (Barkham 2014). Unbeknownst to the listeners, the song was commissioned by the US Customs and Border Protection as part of a 
larger multi-million-dollar campaign to deter immigration from Honduras, Guatemala and El Salvador (Barkham 2014).

The use of visual images and narratives (in this case a song) as a means of shaping migrations is not new, nor is it restricted to the case of La Bestia. For example, in her analysis of the International Organization for Migration's (IOM) anti-trafficking campaign materials, Andrijasavic (2007) concluded that the production and circulation of images of wounded and lifeless female bodies was a central technique in IOM's efforts to deter Eastern European women from participating in labour migration to Europe during the 1990s. At the same time, the campaigns' visual representations of men as the perpetrators of sex-trafficking had the effect of criminalizing Eastern European men, thereby reinforcing gender stereotypes and the geographical parameters of European membership during a time in which European integration demanded the reconstruction of symbols and structures. According to Andrijasavic (2007), the IOM's campaigns can be understood as enacting “...a (discursive) containment that limits the possibilities for creating new images of female subjectivity, criminalize (sic) the movement of non-EU nationals and hence holds in place and out of EU citizenship, the bodies of eastern European women.

\section{Battling the Beast}

While actors from around the world travelled to southern Mexico to capture beastly stories and images to engage in the politics of mobility and state-making, others grew concerned about the fall out from this media frenzy. These concerns manifested in a number of responses: Silence, Jest, and Counter-Memory Building.

\section{Speak Not}


Despite the decline in passenger service, the railway remained a central feature of the soundscape and landscape of most towns along the Pacific Coast of southern Mexico. Thus, when the number of riders on La Bestia grew during the first half of the 2000s, and it was not something that could easily be ignored by locals. In the months prior to the 2005 Hurricane Stan, an estimated 500-600 people per day boarded the freight and passenger cars of trains leaving the Tapachula station on the Chiapas Railway (Peters 2005). Because the train did not run on Sundays, the number of deported would accumulate on the weekends and close to one thousand people would board the train at this station on Mondays (ibid). When asked why they preferred the train for travel, passengers would respond quite simply: 'It's free' (ibid).

One local historian recalls the weekly spectacle during this time:

We wanted to move it. Every Friday La Bestia came. This was when it brought its largest convoy, and it divided the city in two for nearly an hour each week while it was stationed there. This was the moment when the migrants would normally jump on the train- actually, it was each Tuesday and Friday, I believe. And you would see the whole show that everyone would start to run for the train...And [for the locals] the train was in the way, so the people couldn't get by and the locals started to say 'oh, stupid thing; it doesn't move', but still, they didn't want to see and would say things like: 'these people who climb on the train are parasites.' So the image that local people have is that these are bad persons [those who ride the train] and we shouldn't help them. And we started to see a rejection of the migrants 'el catracho, el cachuco 76' the people would say....'they are thieves and they are lazy' (Interview 8).

\footnotetext{
${ }^{76}$ Catracho is a disrespectful reference to persons from Honduras; Cachuco disrespectfully refers to Central Americans and roughly translates as 'dirty pig' (Vogt 2013).
} 
Despite the hyper-visibility of this phenomenon, many residents opted to close their eyes rather than to think, see or discuss these events. As one local reflected: “...there is denial in this region; local inhabitants deny that all of this happened... the people say 'I don't want to find out. I don't want to know.' A short time ago, I was talking to an older colleague of mine... He said 'that is dirty history of the Soconusco, this is history that is not worth telling and that is better to forget.' And, yes, we pretended as though this didn't happen" (Interview 8; author's translation).

Resistance to speak about $\mathrm{La}$ Bestia also extends into civil society organizations in southern Mexico. One interview conducted for this study began with the insistence that they could not contribute to my study because they had made strategic decisions about whether to address the issue. S/he explained:

We are sick of the train discourse. I mean, we've had it up to here with it. Every time they say train....I mean, of course, we must recognize the great drama and difficult problems, but we try in our discourse to not even mention it; we try to have a much more integral view of migration. To view migration in Mexico as only transit migration, and to focus on the train, is one of the worst situations, one of the worse decisions made by so many people, including many organizations. This is because, first, the train is not even $30 \%$ of the route. Secondly, because you cannot build migration policy solely around people who are passing through. It is also a way of revictimizing migrants and focusing on criminal elements when migration is so much more...we try to have a much more integral discourse with regards to migration. So, we barely touch upon the whole topic of transit for these reasons that I mention, and we try to focus on other populations that are important in this region and who suffer xenophobia and violence in forms which are 
perhaps not as direct as the violence suffered on the train, but which are still subtle and tremendous (Interview 7, 2014).

\section{Critical Jest}

A second response was to openly critique La Bestia in jest. One example of this response is the thirteen-minute short film, Danger! Journalists Crossing / ¡Peligro! ¡Cruce de Periodistas! (Berger 2015). The film uses comedy to challenge the dominant narratives and practices which the media had utilized in reporting on the Beast.

Armando Medina, a Honduran migrant turned social activist narrates the film. He begins by repeating the familiar tale of a perilous journey to the United States. Then he tells the audience that he expected this but that he was surprised at "...how stupid so many journalists are..." The film then offers a critical portrayal of a number of mediatic 'types': The international TV crew that scolds the migrants for not showing the world their suffering (See Figure 25 on page 196); the "artistic type" who surprises a migrant defecating in the bushes and tries to take his photograph, stating: "What a beautiful creature you are. You're like a Monarch butterfly flying to the north... stay right there. I am going to immortalize this moment," and; the "alternative blogger" who receives no money for his stories and, based on this premise, tries to build an alliance or friendship with migrants. The narrator is clear in his critique: "Sometimes those who say they're our friends are the worst." 


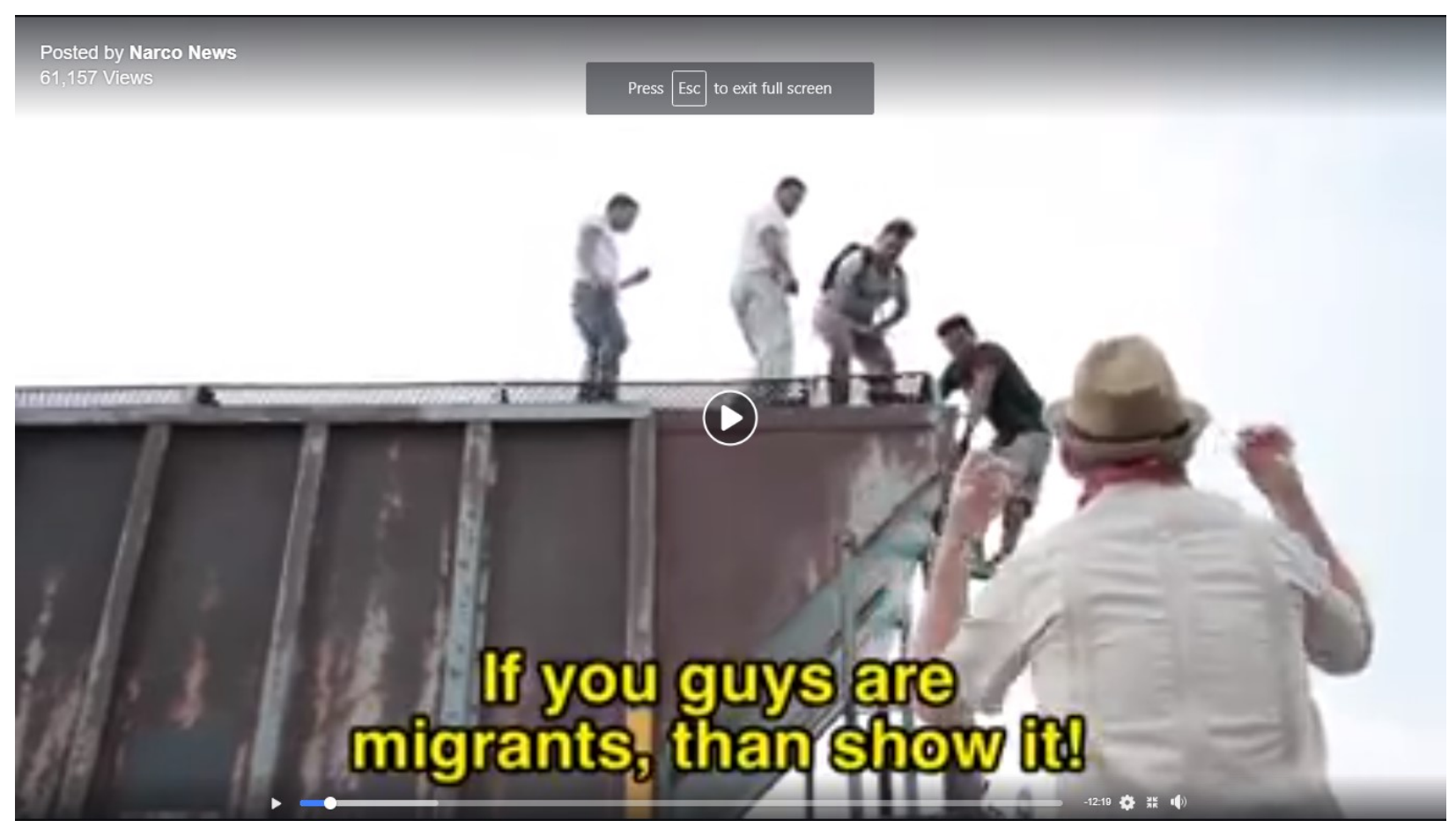

Figure 25 "If You ARE Migrants, Then Show It! The World NeEds to SeE Your SUFFERING!"

Source: Berger, Greg ‘Gringoyo’. 2015. Danger: Journalists Crossing. Narco News TV. Film. Retrieved July 31, 2018 (https://www.youtube.com/watch?v=FrA5PthXufk).

Armando reflects on the problem of media harassment that he and fellow Central Americans have suffered on their journeys, and he decides to fix the problem. He gathers a group of migrants and announces: "Brothers and Sisters! I want to talk to you about those that are less fortunate than us. I am talking about journalists. They always talk about us as if we were criminals, or about our suffering. That needs to change. That's why we're going to open a shelter to rehabilitate journalists...Who supports me?" he asks. The migrants respond in unison "We do!" 


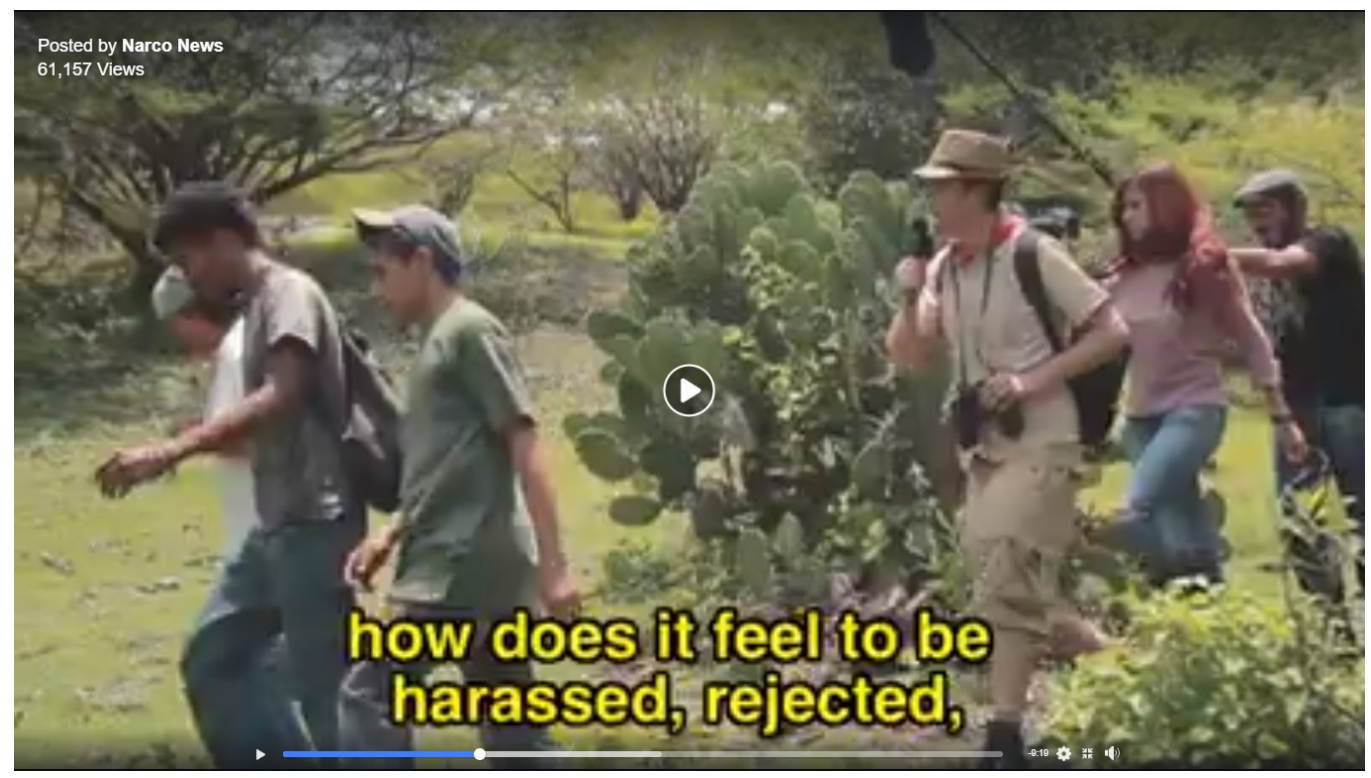

Figure 26 -Journalists Hunt Migrants to CAPTURE THEIR STORIES

Source: Berger, Greg 'Gringoyo'. 2015. Danger: Journalists Crossing. Narco News TV. Film.

Retrieved July 31, 2018 (https://www.youtube.com/watch?v=FrA5PthXufk).

The migrants build their shelter and hunt for journalists (See Figure 27 on page 198). They have trouble catching one, but when they manage to do so, they take him to the shelter and begin his rehabilitation. They ask:" Thomas, you guys come here for a while with your cameras, and then you leave. And then the criminals and the authorities come and treat us worse. Can't you do better journalism?" When the journalist tries to justify his work, the migrants punish him by forcing him to watch hours and hours of news reports on migrants' victimization. 


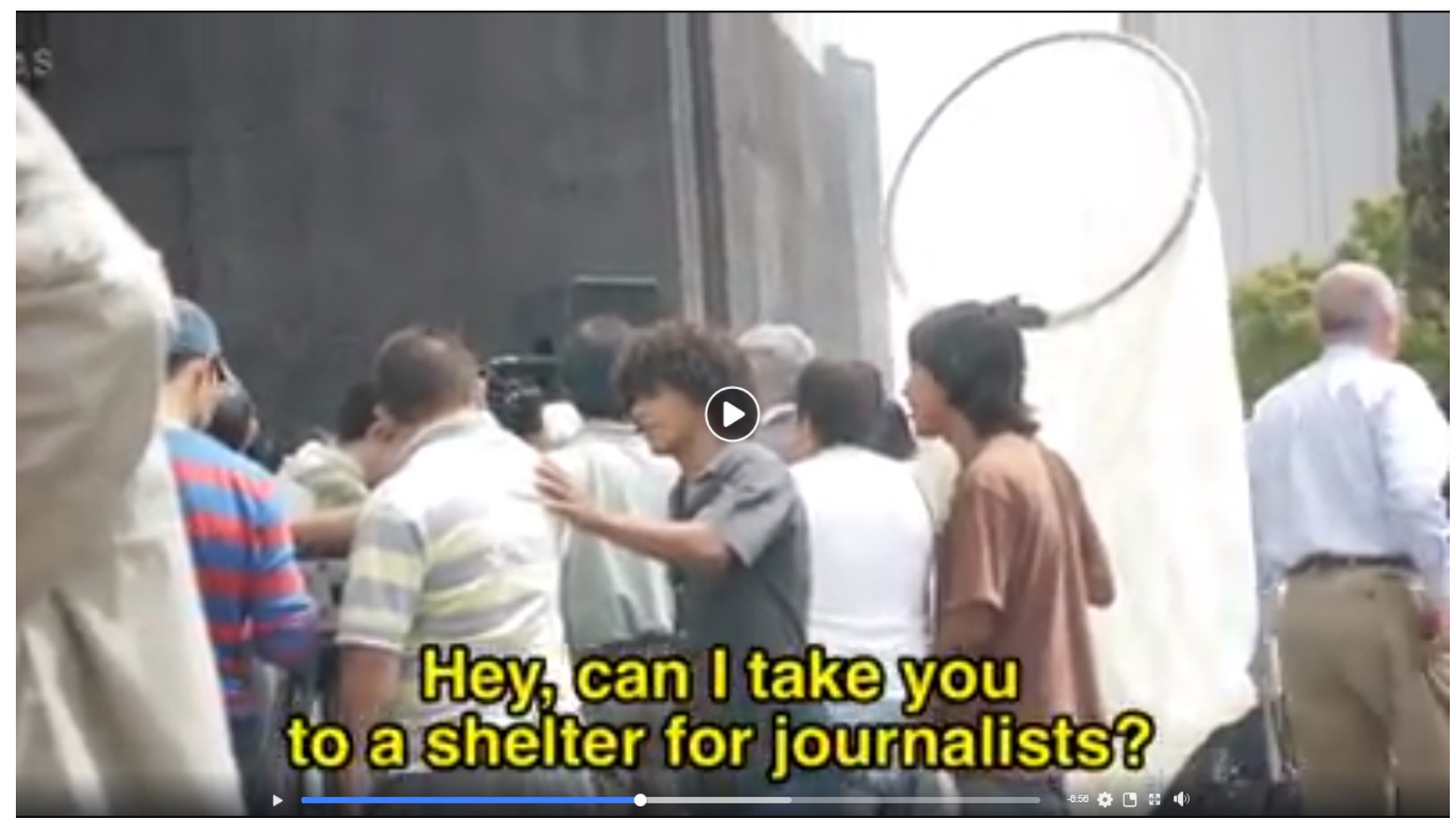

Figure 27- Migrants Hunt JournaLists

Source: Berger, Greg 'Gringoyo'. 2015. Danger: Journalists Crossing. Narco News TV. Film.

Retrieved July 31, 2018 (https://www.youtube.com/watch?v=FrA5PthXufk).

The video ends on an optimistic note. Armando and friends have rehabilitated Thomas, the journalist, and now he no longer reports on migrant criminals and victims for the large, international networks. Instead, he reports for the migrants, by showing their capacity to organize and challenge the structures that oppress them. Armando, the narrator, tells the audience that he will stay in Mexico because he wishes to rehabilitate more journalists and show more migrants the power of organized, collective action.

All of the characters in the film are Central American migrants who have suffered on their journeys though Mexico, but the film maker and crew decided that these were not the stories they wished to tell in the film because“...people are only moved so much by horror 
stories. More often than not it is stories of success, of victory in the face of great odds, and of the power of organizing that motivate people to fight injustice (Mensing 2015). The message is that showing triumphs rather than defeats is often more empowering.

\section{Counter-Memory Building}

Local residents, such as Jorge Villanueva, have turned to historical images and anecdotes to contest the violence which La Bestia symbolically exercises on those who inhabit Mexico's railway space today. His Facebook page Tapachula a Través del Tiempo, actively publishes historical images and descriptions of the Panamericano. These images counter spectacular security performances aboard La Bestia with mundane images of everyday mobilities on the Panamericano before it was a Beast. They counter criminalization of the railway space with narratives and images which celebrate the railway workers and families which founded so many towns along the Pacific Coast.

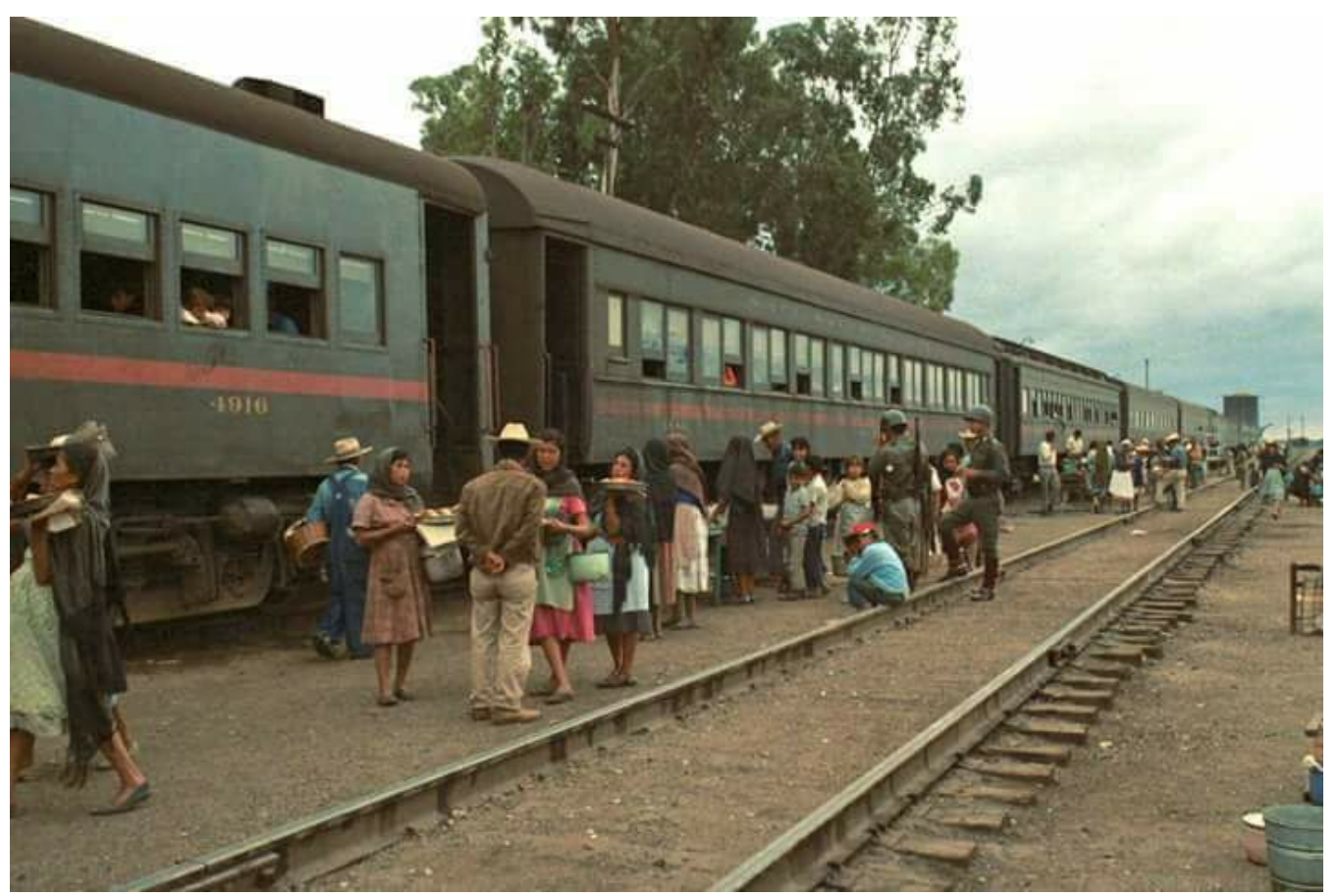

Figure 28 -El Tren Peregrino (The Pilgrim’s Train) 
Source: Villanueva, Jorge. Tapachula a Través del Tiempo. Facebook Page. Posted May 27, 2018.

Retrieved June 3, 2018

(https://www.facebook.com/Por.Jorge.Villanueva/photos/a.258448531254526/470724583360252/?type

\section{$=3 \&$ theater $)$.}

For instance, the above photo was published with the following local knowledge about its use;

"El Tren Peregrino" (The Pilgrim's Train)

Before the FNM was privatized, it was customary each year in the second week of May for the Pilgrim's Train to transport the faithful from Tapachula to Mexico City to visit the Virgin of Guadalupe en Tepeyac. There was an agreement between Chiapas' ecclesiastical authorities and the federal government to offer this particular train service, known as the "Chiapas al Tepeyac," at a reduced cost. It stopped at each of the towns along the Chiapanecan coast, picking up passengers wishing to join the pilgrimage. In Arriaga, the train also collected pilgrims from the interior of Chiapas...If the train left Tapachula on Wednesday, it arrived at the Buenavista Station in Mexico City on Friday. There all of the Chiapanecans who resided in DF exchanged hugs and kisses; they received packages which had been sent by relatives left behind in Chiapas- bread, fruit, sweets, clothing, souvenirs from Chiapas, and objects that been brought over from Guatemala... (Villanueva 2018, posted May 27, author's translation)

Villanueva offers great detail of this annual event which took place on the Panamericano. His post is too long to reproduce here in its entirety. The point is that it counters beastly stories with accounts of everyday mobilities on the Panamericano. 


\section{Concluding Remarks}

Interrogating how power shapes the creation and circulation of visual and cultural representations of infrastructure, and how it affects the political imagination and the uses of the infrastructure space opens an important window on the world of mobility politics. This chapter traced the historical emergence of La Bestia, or The Beast that Devours Migrants, as a symbol or representation of the Panamericano. Counter to popular narratives, which find the origins of this symbol with the migrants themselves, this counter-memory finds its origins and transformation in the United States. Over time, diverse actors and processes have built the symbol of La Bestia, and they have used it as a tool for shaping or influencing the movement of peoples in southern Mexico and Central America. At the same time other groups contest these beastly representations of the railway, the migrants and the communities these pass through.

At the turn of the twenty-first century, the world was given its first glimpse of 'La Bestia,' or The Beast. At first sighting, this Beast debuted as a lawless, dangerous territory filled with bandits, corrupt authorities and street gangs who hunted Central American migrants passing through on their way to the United States (Nazario 2006). This territory was Mexico's southern state of Chiapas, where, just a few years earlier, on the day that the North American Free Trade Agreement (NAFTA) was to go into effect, impoverished indigenous groups in the highlands declared war on the Mexican government, setting off military tensions which would reverberate throughout the region and even the world.

Several years later, the Beast was sighted a second time. Yet, this time its contours were distinct and more clearly drawn. No longer understood as the whole of Chi apas, $L a$ Bestia was now to refer to the cargo train which migrants precariously- and often tragically- 
clung to as a means of moving through the state. Rebranded as 'the Steel Beast which devoured migrants,' Chiapas' cargo trains had joined the ranks of the bandits, corrupt authorities and street gangs which, together, constituted the Mexican Nightmare for any Central American migrant in heroic pursuit of the American Dream (Dirdamal 2005). Since then, La Bestia has been a political symbol and stage upon which Mexican Nightmares and American Dreams has played out for all to see. 


\section{Conclusion-}

On the Politics of Mobility and (the New Frontier of) State-Making

“... after all, the train had always been a sign of upheaval, its function was to disturb the order, to break it and to smash the peace " (Poniatowska 2005: 540; author's translation). ${ }^{77}$

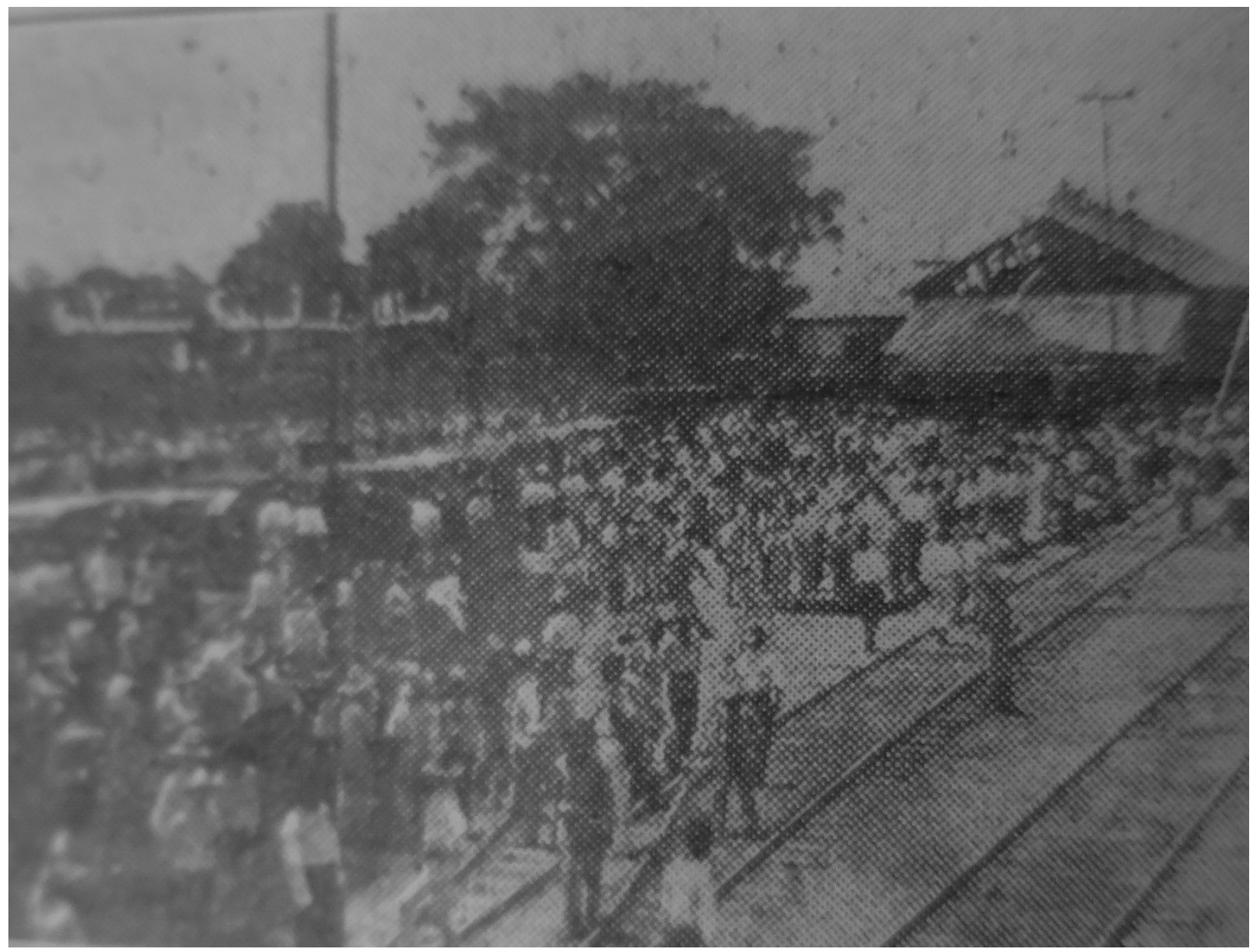

Figure 29- Awaiting the Arrival of A Train at TAPACHUla Station on the PANAMERICANO

Source: FNM. 1931. “Sección Técnica.” Ferronales Tomo II, No. 12. December 31, 1931, p. 6. Mexico: CEDIF Archives.

\footnotetext{
77 “...despues de todo, el tren siempre habia sido el presagio de la conmocion, su funcion era transtornar el orden, requebrajarlo, estrellar la paz" (Poniatowska 2005: 540).
} 
This dissertation began by interrogating the processes which led to the rise of highlyvisible, dangerous migration journeys around the world at the turn of the twenty-first century. It argued that migration and security frameworks are limited in their capacity to explain the politics of migration, and it suggested that an infrastructural approach to studying migration offered a means of developing alternative perspectives on the rise of highly-visible, dangerous migration journeys.

An infrastructural perspective on migration politics asks how infrastructure shapes migration. It does this based on the premise that migrations are not autonomous. They do not emerge solely with the beckoning of markets or the cajoling of states. Rather, migrations are made possible where there exist material and non-material means of movement. Infrastructure offers the means of migration, but it does so discriminately. Not anyone can migrate and not anywhere. The material, social and symbolic features of infrastructure shape the possibility and character of migrations in specific (and constantly changing) ways. In this sense, infrastructure is political. It exercises power, and it produces effects.

What are the advantages of an infrastructural perspective? First, infrastructure draws attention to the mediated nature of migration, and to a whole host of human and non-human intermediaries which shape the possibilities, character and directionality of migrations. From this perspective, migration is not seen as an outcome of historical dialectics of structure and agency, nor is it part of a political dance between migrants and states. Rather, migration is understood to be the product of networked interactions between living beings, material technologies and 
symbols. For instance, in Chapter 1, we see how symbolic mobilities, such as ecological inventories and ideas of Panamericanism were circulated by promotores to stimulate the movement of railway capitalists and migrant-settlers, who then activated their own networks of commerce and kinship to stimulate the movement of migrant labourers for agricultural production and railway construction. Similarly, in the final chapters, we see how the forced movement and containment of U.S. deportees stimulated the production and stimulation of human inventories (Chapters 5 and 6), which provided the impetus for the migration and settlement of a whole host of actors and institutions - journalists, missionaries, organized criminals and state authorities- interested in engaging in the politics of protection.

Secondly, infrastructure offers unique space and vantage point from which to read the relationship between the politics of mobility and the politics of state-making. The core argument of this work is that infrastructure and mobilities make states, but how this occurs changes with time. In Mexico, we see at least three modes of (infrastructural) state-making since the end of the $19^{\text {th }}$ century. We encounter the first mode in Chapter 1, which illustrates how ecological inventories were produced and circulated to stimulate the movement of people necessary to build the Panamericano. The creation and settlement of this railway space, I argue, offered a means of capturing the territory of the Soconusco. Chapter 2 suggests that, because the railways were made unavailable during the revolution, post-revolutionary state-making shifted toward the construction of roads and the production and circulation of cultural inventories to stimulate tourist mobilities. The creation of alternative infrastructure spaces (roads, but also hotels, restaurants, gas stations, and other tourist infrastructure), I argue, offers a second chance to capture territory after the Pan-American Railway fails to offer adequate conditions for infrastructural state-making in southern Mexico. 
The final chapters suggest that state-making has shifted once again at the turn of the twenty-first century. State-making today involves widespread infrastructure reform (chapter 3), the forced un/settlement, containment and documentation of populations who have, for varying reasons, remained outside the structures of capitalism and the state (Chapter 4 and 5). It also involves the creation of symbols which can be used to shape mobility (Chapter 6). The restructuring of the railway, I suggest, creates fissures in this infrastructure space for statemaking which, today, centres on capturing populations and bringing them under state government in various ways. In the final pages of this dissertation, I briefly discuss the implications of this new frontier of state-making for southern Mexico, and I underline the significance of the counter-memories presented here.

First, the implications: The production and circulation of beastly stories and images of migrants riding the railways are as integral to infrastructural state-making today as were the ecological inventories and the cultural inventories of the $19^{\text {th }}$ century and mid- $20^{\text {th }}$ century. The type of data collected for these human inventories constitutes a fact-finding mission offers evidence in support of building the forces of coercion which have traditionally been used to seize territories and populations for state-building. This dissertation suggests that we think critically and historically about the practice of creating and circulating knowledge about acts of violence and victimization among migrant populations of southern Mexico. There are inherent dangers in building a relationship between migration and security and research agendas concerned with migration must critically engage the problem of security by deconstructing those narratives and practices which securitize migration.

Historical memory is profoundly political, and the remembrance (or forgetting) of events, peoples and ideas all shape our ability to see and act in the world today. In offering these 
counter-memories, this dissertation aims to change the way we see and act in relation to the global migration crisis today. As I write the final pages of this dissertation, a migrant caravan of thousands of Honduran migrants finds itself stuck on the international bridge which connects Tecun Umáan, Guatemala to Ciudad Hidalgo, Mexico. For days, security spectacles have dominated the media in Central America and North America. Threatening tweets from one president to another; fences erected and knocked down by thousands of people; people repelling off the bridge and forging the Rio Suchiate. The same dichotomous production of discourse and practices which, for over two decades, drove human versus national security debates on $L a$ Bestia are today being produced from a bridge. Not much has changed.

In offering these counter-memories, this dissertation seeks to break the national-human security stalemate. It sides with locals whose livelihoods and communities have been criminalized and silenced as a result of so many beastly stories. It sides with the railway workers whose space of livelihood, and sacrifices for family and community have been reduced to silence (at best) and criminal shadiness (at worst). It sides with the bayunqueras, whose historical contributions to local railway economy have been erased from view by violent images of accidents, murders, and police chases. It sides with migrants- those whose historical contributions to the railway have been erased, and those who, for two decades now, have been hunted down and forced to show and speak their tragedies, but with little recompense. It sides with Mesoamerican Peoples ${ }^{78}$, whose shared history, world views, and lives are increasingly divided and threatened by the bordering practices of infrastructural state-making.

\footnotetext{
${ }^{78}$ Mesoamerica has been defined as a civilization, which, though culturally diverse, shares a common pre-colonial history that is rooted in a specific geographic region (Batalla 2012). Paul Kirchhoff (1967) described the physical boundaries of Mesoamerica as extending “...from the Panúco River to the Sinaloa River, passing along the Lerma River" in northern Mexico, and "...from the mouth of the Motagua River to the Gulf of Nicoya, passing through Lake Nicaragua" in Central America (Batalla 2012: 7).
} 
References

\section{Bibliography}

Abrams, Philip. 1982. Historical sociology. Cornell University Press.

Adey, Peter. 2006. "If Mobility is Everything Then it is Nothing: Towards a Relational Politics of (Im)mobilities." Mobilities 1 (1): 75-94.

Alegre, Robert F. 2013. Railroad Radicals in Cold War Mexico. Gender, Class, and Memory. Lincoln \& London: University of Nebraska Press.

Alvarado Mendoza, Arturo and Carlos Silva Forné. 2011. "Relaciones de autoridad y abuso policial en la Ciudad de México.” Revista Mexicana de Sociología 73 (3): 445-473.

Andersson, Ruben. 2012. "A game of risk: Boat migration and the business of bordering Europe." Anthropology Today 28(6): 7-11.

Andrijasevic, Rutvica. 2007. "beautiful dead bodies: gender, migration and representation in anti-trafficking campaigns." Feminist Review 86: 24- 44.

Anim-Addo, Anyaa. 2014. “"The Great Event of the Fortnight': Steamship Rhythms and Colonial Communication.” Mobilities 9 (3): 369-383.

Anwar, Nausheen H. 2016. "Asian mobilities and state governance at the geographic margins: Geopolitics and oil tales from Karachi to Taftan.” Ecology and Planning A 48(6): 10471063. 
Aradau, Claudia. 2004. "The perverse politics of four-letter words: risk and pity in the securitisation of human trafficking." Millennium Journal of International Studies 33(2): 251-277.

Aragonés, Ana María. 2011. “Migración Centroamericana y México.” La Jornada. 10 de abril 2011.

Retrieved August 1, 2012 (http://www.jornada.unam.mx/2011/04/10/opinion/031a1eco).

Armijo Canto, Natalia. 2011. "Frontera sur de México: los retos múltiples de la diversidad.” Pp. 35-52 in Migración y seguridad: nuevo desafio en México, edited by Natalia Armijo Canto. México, D.F: CASEDE.

Ashmore, Paul. 2013. "Slowing Down Mobilities: Passengering on an Inter-war Ocean Liner." Mobilities 8 (4): 595-611.

Ashutosh, Ishan and Alison Mountz. 2012. "The Geopolitics of Migrant Mobility: Tracing State Relations Through Refugee Claims, Boats, and Discourses." Geopolitics 17: 335-354,

Austin, Jonathan Luke. 2015. "We have never been civilized: Torture and the materiality of world political binaries." European Journal of International Relations. pp.1-25.

Baca Villanueva, Gustavo. 2002. "Constitución del Ferrocarril del Istmo de Tehuantepec S.A. de C.V." Memorias del V Encuentro Nacional de Investigadores del Ferrocarril. México: SCT, Conaaculta and Museo Nacional de los ferrocarriles mexicanos, 157-158.

Barkham, Patrick. 2014. "La Bestia: The Hit Song the US Border Agency Made to Scare Off Immigrants" The Guardian. July 16, 2014.

Basok, Tanya, Daniele Belanger, Martha Luz Rojas-Wiesner and Guillermo Candiz. 2015. Rethinking Transit Migration: Precarity, Mobility and Self-Making in Mexico.UK: Palgrave Macmillan. 
Batalla, Guillermo Bonfil. [1996] 2012. México Profundo: Reclaiming a Civilization. Translated by Phillip A. Dennis. University of Texas Press.

Benjamin, Walter. 1968. 'Theses of Philosophy of History.' In Illuminations, edited by Hannah Arendt and translated by Harry Zohn. New York: Harcourt Brace Jovanovich Inc, 253-264.

Bigelow, John. 1882 (Oct 1). “The Railway Invasion of Mexico.” Harper's New Monthly Magazine 65 (389):745-757.

Blue, Ethan. 2013. "Finding Margins on Borders: Shipping Firms and Immigration Control Across Settler Space.” Occasion: Interdisciplinary Studies in the Humanities 5 (March 1, 2013): 1-20.

-----. 2015. "Strange Passages: Carceral Mobility and the Liminal in the Catastrophic History of American Deportation." National Identities 17 (2): 175-194.

Brown Scott, James.1935. “The Ideals of Panamericanism.” World Affairs 98 (2): 87-91.

Bueger, Christian and Felix Bethke. 2014. "Actor-networking the 'failed state'—an enquiry into the life of concepts." Journal of International Relations and Development 17(1): 30-60.

Burke, Peter. 2003. "Introduction: Reinventing Historical Sociology.” Pp.58-64 in Handbook of Historical Sociology, edited by Delanty, G. and Isin, E.F. London, Thouand Oaks and New Delhi: Sage Publications.

Byam, William W. 1897. A Sketch of the State of Chiapas, Mexico. Los Angeles, California: GEO Rice \& Sons. Retrieved April 2, 2018 in Google Ebooks:

(https://books.google.ca/books?id=9WgLAQAAIAAJ\&printsec=frontcover\&source=gbs_ge_su $\underline{\text { mmary } \mathrm{r} \& \mathrm{cad}=0 \# \mathrm{v}=\text { onepage } \& \mathrm{q} \& \mathrm{f}=\mathrm{false})}$ 
Calhoun, Craig, 2003. “Why Historical Sociology?” Pp. 383-395 in Handbook of Historical Sociology, edited by G. Delanty, and E. F. Isin. London, Thousand Oaks and New Dehli: Sage Publications.

Callon, Michel, John Law, and Arie Rip. 1986. "How to study the force of science.” Pp. 3-15 in Mapping the dynamics of science and technology. United Kingdom: Palgrave Macmillan.

Cammisa, Rebecca. 2009. Which Way Home. Mr Mudd Films, HBO Documentary.

Campos, Javier. 2001. "Lessons from railway reforms in Brazil and Mexico.” Transport Policy 8 (2001) $85-95$.

Campos, Guillermo Ríos. 2000. "El papel de la privatización en el proyecto de modernización empresarial de los Ferrocarriles Nacionales de México." Pp. 98-103 in Memorias del IV Encuentro Nacional de Investigadores del Ferrocarril. México: Conaculta and Museo Nacional de los Ferrocarriles Mexicanos.

Carney, William P. 1950. “On the Highroads of Mexico: Three Gaps Remain. Hotel Rates Cited.” New York Times. February 9, 1950. P. AS15.

Caruso, John Anthony. 1951. "The Panamerican Railway.” Hispanic American Historical Review 31 (4): 613-620.

Casas-Cortes, Maribel, Sebastian Cobarrubias and John Pickles. "Riding Routes and Itinerant Borders: Autonomy of Migration and Border Externalization." Antipode 47 (4): 894-914.

Casillas, Rodolfo. 1991. "Migraciones centroamericanas en México. Semblanza de un proceso social emergente.” Relaciones. El Colegio de México. Pp. 67-81.

-----. 2007. Una vida discreta, fugaz y anónima. Los centroamericanos transmigrantes en México. México, DF: Comisión Nacional de Derechos Humanos México and IOM. 
Castañón Gamboa, Fernando. [1951] 1989. “Panorama histórico de las comunicaciones en Chiapas.” Pp. 279-328. In Lecturas Chiapanecas II, edited by Cuauhtémoc López Sánchez. Gobierno del Estado de Chiapas. Consejo Estatal para el Fomento a la Investigación y Difusión de la Cultura.

Castillo, Manuel. 2005. "Fronteras, migración y seguridad en México." Alteridades 15 (30): 51-60.

Castles, Stephen and Mark Miller. [1993] 2009. The Age of Migration. New York: The Guilford Press.

Chamayou, Gregoire. 2012. Manhunts. A Philosophical History. Princeton and Oxford: Princeton University Press.

Choy Gómez, Jorge, Gerardo Espinosa Santos, Carmen Fernández Casanueva, Hans Kabsch Vela, Diego Lorente and Santiago Martínez Junco. 2014. MUMISOC: La oportunidad de un museomemorial de las migraciones en el Soconusco. Febrero 2014.

Chu, Julie Y. 2016. “Boxed In: Human Cargo and the Technics of Comfort.” International Journal of Politics, Culture and Society 29 (4): 409-421.

Coatsworth, John H. 1981. Growth Against Development. The Economic Impact of Railroads in Porfirian Mexico. DeKalb: Northern Illinois University Press.

Collins, Alan. 2007. Contemporary Security Studies. Oxford and New York: Oxford University Press.

Commission of the European Communities. 1992. Treaty on the European Union. Retrieved July 31 , 2018 (https://europa.eu/europeanunion/sites/europaeu/files/docs/body/treaty_on_european_union_en.pdf)

Conrad, Joseph. [1904] 2007. Nostromo. Oxford and New York: Oxford University Press.

Cornelius Wayne, Philip Martin and James F. Hollifield. 1994. "Introduction: The ambivalent Quest for Migration Control. In Controlling Immigration: a global perspective, edited by Wayne 
Cornelius, Philip Martin and James F. Hollifield. Stanford California: Stanford University press, 3-42.

Crosswalk. 2001. "Elite Mexico Force Faces Accusations.” Crosswalk Online. August 16. Retrieved April 11, 2012 (http://www.crosswalk.com/748700/)

Coutin, Susan Bibler. 2007. Nations of Emigrants. Shifting Boundaries of Citizenship in El Salvador and the United States. New York: Cornell University Press.

Cowen, Deborah. 2014. The deadly life of logistics. University of Minnesota Press.

-----. 2010. “A geography of logistics: Market authority and the security of supply chains.” Annals of the Association of American Geographers 100(3): 600-620.

Cresswell, Tim. 2010. “Toward a Politics of Mobility." Ecology and Planning D: Society and Space 28: 17-31.

Cuéllar, Mireya. 2000. “El tiempo parece detenido en la vieja estación ferrocarrilera.” La Jornada. December 18, 2000. Retrieved June 20, 2015

\section{(http://www.jornada.unam.mx/2000/12/18/048n1con.html)}

Davies, Richard. 2000. “'Neither here nor there?' the implications of global diasporas for (inter)national security.” Pp 23-46 in Migration, Globalization and Human Security, edited by David T. Graham and Nana K. Poku. New York: Routledge.

Davis, Henry Gassaway. 1907. Pan-American Railway: Reports, Etc. 1823-1916. Washington, D.C.: Press of Gibson Bros. Retrieved October 2018 (https://babel.hathitrust.org/cgi/pt?id=njp.32101054792948;view=1up;seq=1) 
Davis, Jason and Halie Eakin. 2013. “Chiapas’ Delayed Entry into the International Labour Market: A Story of Peasant Isolation, Exploitation, and Coercion.” Migration and Development 2 (1): 132149.

Dean, Mitchell. 2003. "Prologue for a genealogy of war and peace: Genealogical approaches.” Pp. 180190 in Handbook of Historical Sociology, edited by G. Delanty and E.F. Isin. London: Sage Publications.

de Certeau, Michel. 1984. The Practice of Everyday Life. Translated by Steven Rendall (Trans.). Berkeley, Los Angeles, London: University of California Press.

De Genova, Nicholas. 2013. “Spectacles of migrant 'illegality': the scene of exclusion, the obscene of inclusion.” Ethnic and Racial Studies 36 (7): 1180-1198.

Delanty, Gerard. and Engin. F Isin. 2003. “Introduction: Reinventing Historical Sociology.” Pp.1-8 in Handbook of Historical Sociology, edited by G. Delanty, and E.F. Isin. London: Sage Publications.

DHS (Department of Homeland Security). 2013 Yearbook of Immigration Statistics (table 39; removals of inadmissible or deportable aliens out of United States based on an order of removal). Retrieved June 30, 2015 (http://www.dhs.gov/yearbook-immigration-statistics-2013$\underline{\text { enforcement-actions) }}$

Duvell, Franck. 2012. “Transit migration: A blurred and politicised concept.” Population, Space and Place 18 (4): 415-427.

Easterling, Keller. 2014. Extrastatecraft: The Power of Infrastructure Space. London and New York: Verso Books. 
El Diario del Sur. 1954. "Nos dicen que en breve desaparecerá el servicio del mixto a Mapastepec.” El Diario del Sur, Año VI, no. 2082, 23 de julio, Front page and p. 4.

El Diario del Sur. 1955. ““Nuevo ferrocarril para Tapachula. El Día primero comenzará a dar su servicio el 'Centroamericano'. Trenes directos, rápidos y de primera van a ser los que trabajen de aquí a Veracruz.” El Diario del Sur, Año VII, no. 2296, 19 de abril, Front page.

El Diario del Sur. 1959. "Los ferrocarrileros de Tapachula volvieron a su trabajo.” El Diarios del Sur, Año XII, no. 3557, 7 de abril, front page and p. 4.

El Diario del Sur. 1968. "Peligro de perderse parte de la cosecha de algodón ante la falta de los Braceros.” El Diario del Sur Año XX, no. 9228.19 de enero, front page,.

El Diario del Sur. 1983. "Descarado atraco a turistas salvadoreños: Agentes de migración y aduana robaronles (sic) 80 dolares en la terminal de la Colon ayer aun cuando iban bien documentados." 2 de marzo 1983. Diario del Sur. Año xxxv, num. 13,966. P. 4 back page headline

El Diario del Sur. 1985. "Vulgares rateros son agentes migratorios: Siguen extorsionando a turistas centroamericanos; ayer les quitaron 35 y 42 mil pesos a visitantes nicaragüenses. Gobernación continúa solapándolos.” 24 enero 1985. Diario del Sur, año XXVII, num. 14, 550, front page headline, pp. 1 and 4

El Diario del Sur. 1987. “'Madrinas' de PJF extorsionan a turistas.” El Diario del Sur. Año XL, no. 15,431. 29 de diciembre, Front page headline.

El Diario del Sur. 1990. "Milliones de pesos dejan 'pollos’ a la migra.” 3 de enero 1990. El Diario del Sur, año xlii, num. 16,046, front page headline and back 
El Orbe. 1992. "Tres ilegales fueron aprehendidos cerca de la estación de Ferronales.” El Orbe, July 23, p. 10.

El Orbe. 2005. "Vinculan a la Mara Salvatrucha con el Grupo Terrorista Al-Qaeda." El Orbe, 15 de febrero. pp. 1 and 8 .

El Orbe. 2005a. "Con daños severos 10 puentes ferroviarios." El Orbe. 9 de octubre, p.43. Tapachula, Chiapas.

El Sol de Soconusco. 1955. "La Cámara Nal. De Comercio se preocupa por problemas grales.” El Sol de Soconusco Año III, no. 635. 12 de marzo, Front and back pages 1 and 4.

Estache, Antonio, Marianela González, and Lourdes Trujillo. 2002. "What Does 'Privatization” Do for Efficiency? Evidence from Argentina's and Brazil's Railways." World Development 30 (11): $1885-1897$.

Fassin, Didier. 2007. "Humanitarianism: a nongovernmental government." Nongovernmental politics. Pp. 149-160.

-----. 2012. Humanitarian reason: a moral history of the present. University of California Press.

Ferris, Elizabeth G. 1984. “The Politics of Asylum: Mexico and the Central American Refugees.” Journal of Interamerican Studies and World Affairs 26 (3): 357 -384.

-----. 1987. The Central American Refugees. New York. Westport, Connecticut and London: Praeger.

FNM. 1916. "Informe del Presidente Ejecutivo, Don Alberto Pani al Presidente de la Junta Directiva." In Octavo Informe Anual de los Ferrocarriles Nacionales de México Correspondiente al año social que terminó el 30 de junio de 1916. Edición en español. (Courtesy of CEDIF Archives)

FNM. 1931. Ferronales Tomo II, No. 12. December 31, 1931. (Courtesy of CEDIF archives) 
-----. 1955. Ferronales. Tomo XXV. No. 3-4. marzo- abril 1955. (Courtesy of CEDIF archives)

FNM. 1991. Análisis de Ocupación de Trenes de Pasajeros. Subdirección General de Tráfico. Gerencia de Tráfico de Pasajeros. 18 de febrero 1991. (Courtesy of CEDIF archives)

FNM. 1994. Comité Comercial Gerencia de Servicios de Pasajeros. 24 de enero 1994.

FNM. 1994a. Supresión de servicios de pasajeros de baja rentabilidad.

Ferrocarriles Nacionales de México. 1993. Estudio de Servicios de Pasajeros. Subdirección General de Planeación y Sistemas y Subdirección General Comercial y de Servicios del FNM, enero 1993.

Ferrocarriles Nacionales de México. 1991. Análisis de ocupación de trenes de pasajeros. FNM Gerencia de Tráfico de Pasajeros.

Ferrocarriles Nacionales de México. 1987. Los Ferrocarriles de México 1837-1987. México, DF: FNM.

Feys, Torsten. 2016. “Transoceanic Shipping, Mass Migration, and the Rise of Modern-Day International Border Controls." Mobility in History 7(1):151-162.

Ficek, Rosa Elena. 2014. "The Pan American Highway: An Ethnography of Latin American Integration.” Ph.D. dissertation, Department of Anthropology, University of California Santa Cruz.

-----. 2016. "Imperial Routes, National Networks, and Regional Projects in the Pan-American Highway, 1884-1977." The Journal of Transport History 37 (2): 129-154.

FNM. 1911. Facts and Figures About Mexico and its Great Railway System the National Railways of Mexico. Traffic and Industrial Departments of the National Railways of Mexico. México, D.F. 
Frelick, Bill. 1991. "Running the Gauntlet: The Central American Journey in Mexico.” International Journal of Refugee Law 3(2): 208-242.

Foucault, Michel. 1977. "Nietzsche, Genealogy, History.” Pp. 139-164 in Language, Counter-Memory, Practice: Selected Essays and Interviews, edited by D. F. Bouchard. Ithaca: Cornell University Press.

1991. "Questions of method.” Pp. 73-86 in The Foucault effect, edited by Graham Burchell et al Chicago University Press.

-----. 1998. “Nietzsche, genealogy, history.” In Essential works of Michel Foucault 1954-1984. Vol. 2, edited by J. Faubion: 367-391.

-----. 2007. Security, territory, population: lectures at the Collège de France, 1977-78. Springer.

Garcés-Mascareñas, Blanca. 2015. "Revisiting Bordering Practices: Irregular Migration, Borders, and Citizenship in Malaysia.” International Political Sociology 9(2): 128-142.

García, Juan de Díos. 1992. "El tren pollero ya no dará servicio de pasaje.” La Voz del Sureste. No. 3976 (8 de enero 1992), p.8.

García, María Cristina. 2006. Seeking Refuge: Central American Migration to Mexico, the United States, and Canada. University of California Press.

Gibney, Matthew J. 2008. "Asylum and the Expansion of Deportation in the United Kingdom." Government and Opposition 43 (2): 146-167.

Glissant, Édouard. 2007. "For Opacity.” Pp. 189-194 in Poetics of Relation. Translated by Betsy Wing. Ann Arbour: The University of Michigan Press. 
González-Murphy, Laura V and Rey Koslowski. 2011. Entendiendo el cambio a las leyes de inmigración de México. Washington, D.C. Woodrow Wilson International Center for Scholars. Mexico Institute. March 2011.

Gorostiza, Francisco Javier. 2011. Renacimiento de los ferrocarriles mexicanos de carga. Balance de la privatización al año 2010. México, DF: Asociación Mexicana del Ferrocarril.

-----. 2010. Los Ferrocarriles de la Revolución Mexicana. México, D.F.: Siglo XXI Editores.

Gruel Sández, Victor Manuel. 2017. “La inauguración de la Carretera Panamericana. Turismo y esterotipos entre México y Estados Unidos.” Estudios Fronterizos 18 (36): 126-150.

Grupo Coppan SC. 2008. "Despenalización de la migración indocumentada en México.” Analítica Internacional. Mayo 12. Retrieved August 26, 2016.

GTD. 2008. "Conference Report- International Migration, Multi-Local Livelihoods and Human Security: Perspectives from Europe, Asia, Africa and Latin America." Gender, Technology and Development 12 (3): 525-530.

Guardian, The. 2014. "Migrants Risk Life and Limb to Reach the US on Train Known as the Beast." The Guardian, August 23. Retrieved October 10 (https://www.theguardian.com/world/2014/aug/23/migrants-mexico-train-the-beast-fleeingpoverty)

Guldi, Jo. 2012. Roads to Power: Britain Invents the Infrastructure State. Cambridge and London: Harvard University Press. 
Gutiérrez, Óscar. 2014. "Tras 9 años, reanuda La Bestia ruta en Chiapas.” El Universal. 23 de mayo. Retrieved October 10, 2018 (http://archivo.eluniversal.com.mx/estados/2014/chiapas-ruta-bestia$\underline{-1012573 \cdot h t m l})$.

Hagan, Jacqueline, Karl Eschbach, and Nestor Rodríguez. 2008. “U.S. Deportation Policy, Family Separation, and Circular Migration." The International Migration Review 42 (1): 64-88.

Harbitz, Mia and María del Carmen Tamargo. 2009. The Significance of Legal Identity in Situations of Poverty and Social Exclusion: The Link between Gender, Ethnicity, and Legal Identity. Washington, D.C: Inter-American Development Bank.

Herzberg Yohal, Ernesto. 2000. "La historia de los ferrocarriles en México.” Pp. 104-110 in Memorias del IV Encuentro Nacional de Investigadores del Ferrocarril. México: Conaculta and Museo Nacional de los Ferrocarriles Mexicanos.

Heyman, Josiah. 2008. "Constructing a virtual wall: Race and Citizenship in US-Mexico Border Policing." Journal of the Southwest. 305-333.

Hochschild, Adam. 1998. King Leopold's Ghost. A Story of Greed, Terror, and Heroism in Colonial Africa. Boston and New York: Houghton Mifflin Company.

Hoffman, Carl W. 1945. "By Road from Mexico City to the Guatemalan Border.” Bulletin Pan American Union 79: 691-698.

Huysmans, Jef. 2000. "The European Union and the Securitization of Migration.” Journal of Common Market Studies 38 (5): 751-777. 
Instituto Nacional de Migración (INM). 1994. Operativo Beta: Migración Indocumentada, Vigilancia y

Seguridad en la Frontera. Informe Mensual de Trabajo. Noviembre 1994. Tijuana, Baja California.

Instituto Nacional de Migración (INM). 1997. Informe bimestral de las actividades realizadas por el grupo de protección a migrantes Beta Sur con sede en la Ciudad de Tapachula, Chiapas, correspondiente a los meses de marzo y abril de 1997. (Bi-monthly activities report for the migrant protection group Beta Sur, with headquarters in Tapachula, Chiapas. March and April 1997). Tapachula de Córdoba y Ordoñez, Chiapas: Coordinación del Programa Beta Sur. May 1997.

Instituto Nacional de Migración. 1998a. Informe correspondiente a los meses de enero y febrero de 1998 que presenta al Comité Técnico para el Seguimiento de la Operación del Grupo de Protección a Migrantes Beta Sur. (January and February 1998 Report for the Technical Committee for Monitoring the Operations of the migrant protection group Beta Sur.) Tapachula de Cordova y Ordoñez, Chis: INM Delegación Regional Chiapas. March 5, 1998.

Instituto Nacional de Migración. 1998b. Informe correspondiente a los meses de marzo, abril y mayo de 1998 que presenta al Comité Técnico para el Seguimiento de la Operación del Grupo de Protección a Migrantes Beta Sur. (March, April and May 1998 Report for the Technical Committee for Monitoring the Operations of the migrant protection group Beta Sur.) Tapachula de Cordova y Ordoñez, Chis: INM Delegación Regional Chiapas. June 1998.

Instituto Nacional de Migración. 1998c. Actividades, resultados, retos y líneas de acción para 1998 del grupo interinstitucional de protección a migrantes Beta Sur Tapachula-Pijijiapán (Activities, results, challenges, and lines of action for the 1998 Inter-Institutional Migrant Protection Group 
Beta Sur Tapachula-Pijijiapán). Tapachula de Cordova y Ordoñez, Chis: Coordinación de supervisón y control operativo, dirección de protección a migrantes Grupo Beta Sur TapachulaPijijiapán of INM Delegación Regional Chiapas. June 1998.

Instituto Nacional de Migración (INM). 2001a. Proyecto de Reestructuración de los Grupos Beta de Protección a Migrantes. SEGOB y INM: 22 de mayo, 2001.

Instituto Nacional de Migración (INM). 2001b. Documento de análisis y sugerencias para el funcionamiento e instalación de los Grupos Beta. Marzo. 2001.

Instituto Nacional de Migración (INM-SEGOB). 2005. “Grupos Beta de Protección a Migrante 2005.” Biblioteca de la Unidad de Política Migratoria, INM- SEGOB. México, D.F.

Instituto Nacional de Migración (INM). 2012. Grupos Beta del INM. Protección al Migrante. Retrieved April 14, 2012 (http://www.inm.gob.mx/index.php/page/Grupo_Beta)

Instituto Nacional de Migración (INM). 2014. Guía para los migrantes. Retrieved Sept. 8, 2016 (http://www.inm.gob.mx/static/grupos_beta/GUIA_MIGRANTES.pdf)

Jeandesboz, Julien. 2014. "EU border control: violence, capture, and apparatus." Pp.115-135 in Crisis and Migration: Critical Perspectives, edited by Anna. New York: Routledge.

Joppke, Christian. 1998. "Immigration Challenges the Nation-State." Pp. 6-42 in Challenge to the Nation-State: Immigration in Western Europe and the United States, Oxford, United Kingdom: Oxford University Press.

Kasparek, Bernd, Nicholas De Genova and Sabine Hess. 2015. "Bordering.” Cultural Studies 29(1): 5587. 
Keenan, Thomas. 2002. "Publicity and indifference (Sarajevo on television)." Publications of the Modern Language Association of America 117 (1):104-116.

Kessides, Ioannis Nicolaos. 2004. Reforming Infrastructure: Privatization, Regulation and Competition. World Bank Policy Research Report 28985. Oxford University Press and World Bank. Retrieved August 5, 2018

(http://documents.worldbank.org/curated/en/709301468779183565/pdf/289850PAPER0reformin g0infrastructure.pdf)

Klaegar, Gabriel. 2012. "Rush and Relax: The Rhythms and Speeds of Touting Perishable Products on a Ghanaian Roadside." Mobilities 7 (4): 537-554.

Kritz, Mary W. 2001. “Population Growth and International Migration: Is There a Link?” Pp. 19-41 in Global migrants, Global Refugees, edited by A.R. Zolberg and P.M. Benda. New York and Oxford: Berghahn Books.

Larkin, Brian. 2013. "The politics and poetics of infrastructure." Annual Review of Anthropology 42: 327-343.

Latour, Bruno, 1990. "Technology is society made durable.” The Sociological Review 38(S1): 103-131.

Laughlin, Ruth A. 1939. "Rail Tour of Tropics. A 20-Mile an Hour Pullman Car Ride Through Tehuantepec to Guatemala City." New York Times, March 19, p.149.

Law, John. 1992. "Notes on the theory of the actor-network: Ordering, strategy, and heterogeneity." Systemic practice and action research 5(4): 379-393.

Lewis, Daniel. 2007. Iron Horse Imperialism. The Southern Pacific of Mexico. 1880-1951. Tucson: University of Arizona Press. 
Li, Tania Murray. 2007. “Governmentality.” Anthropológica 49: 275-281.

López Peláez, Antonio and Sagrario Segado Sánchez Cabezudo. 2010. "Privatization Policies or Degradation Policies? The Case of Spanish Railways.” Revista Internacional de Sociología (RIS) 68 (3): $757-773$.

Lurtz, Casey Marina. 2016. "Insecure Labor, Insecure Debt: Building a Workforce for Coffee in the Soconusco, Chiapas." Hispanic American Historical Review 96 (2): 291-318.

Mainwaring Cetta and Noelle Brigden. 2016. "Beyond the Border: Clandestine Migration Journeys." Geopolitics 21 (2): 243-262.

Mann, Michael. 1984. "The autonomous power of the state: its origins, mechanisms and results." European Journal of Sociology 25(2): 185-213.

Marchand, Marianne. 2008. "The Violence of Development and the Migration/Insecurities Nexus: Labour migration in a North American Context.” Third World Quarterly 29 (7): 1375-1388.

Martin, Craig. 2011. "Desperate Passage: Violent Mobilities and the Politics of Discomfort." Journal of Transport Geography 19: 1046-1052.

Martínez, Daniel E. and Jeremy Slack. 2013. Bordering on Criminal: The Routine Abuse of Migrants in the Removal System. Part II. Possessions Taken and Not Returned. The Immigration Policy Center.

Martínez, Oscar. 2010. Los migrantes que no importan: En el camino con los migrantes centroamericanos en México. Icaria Editorial.

-----. 2014. The Beast. Riding the Rails and Dodging the Narcos on the Migrant Trail. Translated by Daniela Maria Ugaz and John Washington. New York: Verso. 
Massey, Douglas S., Joaquín Arango, Graeme Hugo, Ali Kouaouci, Adela Pellegrino and J. Edward Taylor. 1993. "Theories of International Migration: A Review and Appraisal." Population and Development Review 19:431-66.

Massey, Douglas S. 2015. “A missing element in migration theories.” Migration letters: An international journal of migration studies 12(3): 279-299.

McLagan, Meg and Yates McKee. 2012. "Introduction." Pp. 9-26 in Sensible Politics. The Visual Culture of Nongovernmental Activism, edited by Meg McLagan and Yates McKee. New York: Zone Books.

Massumi, Brian. 2014. What animals teach us about politics. Duke University Press.

Matthews, Michael. 2014. The Civilizing Machine: A Cultural History of Mexican Railroads, 18761910. Lincoln: University Nebraska Press.

McDonald, W. F., and Paromchik, S. 1996. “Transparency and the police: external research, policing and democracy." Policing in central and Eastern Europe: Comparing Firsthand Knowledge with Experiences from the West, edited by Milan Pagon. Ljubljana, Slovenia: College of Police and Security Studies (Page numbers not available). Retrieved April 11, 2012. https://www.ncjrs.gov/policing/trans17.htm

Medina, José. 2011. “Toward a Foucaultian Epistemology of Resistance: Counter-Memory, Epistemic Friction, and Guerrilla Pluralism.” Foucault Studies 12: 9-35.

Merlingen, Michael. 2003. "Governmentality. Towards a Foucauldian Framework for the Study of IGOs." Cooperation and Conflict: Journal of the Nordic International Studies 38 (4): 361-384. 
Merriman, Peter. 2016. "Mobility Infrastructures: Modern Visions, Affective Environments and the Problem of Car Parking.” Mobilities 11(1): 83-98.

Mensing, Alex. 2015. “The Making of 'Danger: Journalists Crossing’ Migrants Defend Their Rights and Their Narrative, too, in the New NNTV Video. NarcoNews Bulletin (April 25, 2015). Retrieved July 31, 2018 (http://narconews.com/Issue67/article4803.html)

Mercado Asencio, Karen and Óscar I. Ortiz Reyes. 2014. El Derecho a la Identidad y la expedición de actas de nacimiento extemporáneas en los Estados de Oaxaca, Guerrero y Chiapas, México. Be Foundation Derecho a la Identidad, A.C. 20 de febrero de 2014. Retrieved August 22, 2016 at (https://www.wilsoncenter.org/sites/default/files/Mercado_Ortiz_Derecho_a_la_Identidad_exped icion de actas.pdf)

Mezzandra, Sandro and Brett Neilson. 2013. Border as Method, or, the Multiplication of Labor. Duke University Press.

Mizutani, Fumitoshi. 1999. “An Assessment of the Japan Railway Companies Since Privatization: Performance, Local Rail Service and Debts.” Transport Reviews 19 (2): 117-139.

Molina, Valente. 2006. Por los Rieles de Chiapas. Mexico: Gobierno de Chiapas.

Mountz, Alison and Nancy Hiemstra. 2012. "Spatial Strategies for Rebordering Human Migration at Sea.” Pp. 455-472 in A Companion to Border Studies, edited by T.M. Wilson and H. Donnan, John Wiley \& Sons.

Mizutani, Fumitoshi. 1999. “An Assessment of the Japan Railway Companies Since Privatization: Performance, Local Rail Service and Debts.” Transport Reviews 19 (2): 117-139. 
Nash, Chris. 2008. "Passenger Railway Reform in the Last 20 Years- European Experience Reconsidered." Research in Transportation Economics 22 (2008): 61-70.

Nazario, Sonia. 2002. “Enrique's Journey. Chapter Three: Defeated Seven Times, a Boy Again Faces 'the Beast'." Los Angeles Times. October 2. Retrieved October 10, 2018 (http://www.latimes.com/nation/immigration/la-fg-enriques-journey-chapter-three-mainbarstory.html)

------. 2006. Enrique's Journey. The Story of a Boy's Dangerous Odyssey to Reunite with his Mother. New York: Random House.

Neilson, Brett. 2012. "Five theses on understanding logistics as power." Distinktion: Journal of Social Theory 13(3): 322-339.

Netz, Reviel. 2004. Barbed Wire: An Ecology of Modernity. Wesleyan University Press.

Nevins, Joseph. 2002. Operation Gatekeeper: The Rise of the 'Illegal Alien' and the Making of the USMexico Boundary. Psychology Press.

-----. 2007. "Dying for a cup of coffee? Migrant deaths in the US-Mexico border region in a neoliberal age." Geopolitics 12(2): 228-247.

New York Times. 1904. “An All-Rail Route to South America: Plans of Different Countries. New York Times. April 17. p.12.

Nolan-Ferrell, Catherine. 2010."Agrarian Reform and Revolutionary Justice in Soconusco, Chiapas: Campesinos and the Mexican State, 1934-1940.” Journal of Latin American Studies 42 (3): 551585. 
O’Neill, Kevin Lewis. 2012. "There is no more room: Cemeteries, personhood, and bare death." Ethnography 13(4): 510-530.

Organización Internacional para las Migraciones (OIM). 2011a. Grupos Beta: El Brazo Humanitario del INM. México, D.F. Organización Internacional para las Migraciones.

Pallister-Wilkins, Polly. 2015. "The humanitarian politics of European border policing: Frontex and border police in Evros." International Political Sociology 9 (1): 53-69.

Parsons, James J. 1965. "Cotton and Cattle in the Pacific Lowlands of Central America." Journal of Inter-American Studies 7 (2): 149-159.

Pérez, Tony. 1955. "Huellas ferrocarrileras.” Sol de Tonalá Año III, no. 110. 11 de septiembre, p. 4.

Peters, María de Jesús. 2005. “Aumenta pobreza la migración.” El Universal. August 31. N.p.

Pierce, Bert. 1952. “Hemisphere Road Adding New Links: Pan-American Highway with AlaskaArgentina Stretch, Greatest Route Project.” New York Times, January 4, p. 44.

-----. 1953. “Hemisphere Road is Nearer Reality: Pan-American Highway Grows with Mexican Network as the Chief Contribution." New York Times, January 7, p.58.

Pineda, Emeterio. 1845. Descripción geográfica del departamento de Chiapas y Soconusco. Mexico. Retrieved Sept. 27, 2017 (https://play.google.com/store/books/details?id=UusxAQAAMAAJ\&rdid=bookUusxAQAAMAAJ\&rdot=1)

Pittman, Patricia. 2016. "Alternative Approaches to the Governance of Transnational Labor Recruitment." International Migration Review 50 (2): 269-314. 
Poku, Nana and David Graham. 1998. "Redefining Security for a New Millennium.” Pp. 1-14 in Redefining Security. Population Movements and National Security, edited by N.K. Poku and D.T. Graham. Connecticut and London: Praeger.

Poku, Nana K., Neil Renwick and John Glenn. 2000. “Human Security in a Globalizing World.” Pp. 922 in Migration, Globalisation and Human Security, edited by D. T. Graham and N. K. Poku. London and New York: Routledge.

Pollard, Hugh. B. C. 1913. “A Railroad Journey in Southern Mexico.” Pp. 54-62 in A busy time in Mexico; an unconventional record of Mexican incident. New York: Duffield and Company.

Preston, John and Dawn Robins. 2013. "Evaluating the Long-Term Impacts of Transport Policy: The Case of Passenger Rail Privatisation.” Research in Transportation Economics 39 (2013): 14-20.

Puente, Teresa. 2001. "Mexico Reforming Border Patrols.” Chicago Tribune. September 10. Retrieved when? (http://articles.chicagotribune.com/2001-09-10/news/0109100211_1 grupo-beta-borderpatrol-migrants)

Rabasa, Ramón. 1895. El estado de Chiapas: geografía y estadística. Recursos del estado, sus elementos, condiciones de riqueza, porvenir agrícola. Mexico. Retrieved May 2017 via Google ebooks:

(https://play.google.com/books/reader?id=A89kAAAAMAAJ\&printsec=frontcover\&output=reader\&hl=e $\underline{\mathrm{n} \& \mathrm{pg}=\mathrm{GBS} . \mathrm{PP} 3)}$

Ravenstein, E.G. 1885. “The Laws of Migration.” Journal of the Statistical Society of London 48 (2) Jun. 1885: 167-235.

Reynoso Nuño, F.J. (2010). Actividad Migratoria. Delegación Regional del INM en Baja California. Powerpoint presentation. Retrieved September 9, 2016 (http://slideplayer.es/slide/39202/) 
Rodgers, Dennis. 2012. "Haussmannization in the tropics: Abject urbanism and infrastructural violence in Nicaragua." Ethnography 13(4): 413-438.

Romero, Matías. 1877. "Bosquejo histórico de la agregación á México de Chiapas y Soconusco y de las negociaciones sobre limites entabladas por México con Centro-América y Guatemala. Colección de documentos oficiales que sirve de respuesta al opúsculo de d. Andrés Dardón, intitulado "La cuestión de límites entre México y Guatemala". Tomo I. 1821-1831.” Palacio de gobierno: México.

Romero, Matías. 1882. "Railways in Mexico: An article by Senor Don Matias Romero, Mexican minister to Washington, in answer to an article of the Hon. John Bigelow entitled "The railway invasion of Mexico." Harper's New Monthly Magazine. October 15. Retrieved July 2018 (https://babel.hathitrust.org/cgi/pt?id=hvd.hndlpk;view=1 up;seq=6)

Rotella, Sebastian. 1992a. "Reducing the Misery at the Border: Immigration: Grupo Beta is an elite Mexican multi-agency force with the task of protecting migrants. It has cut violence and improved relations between U.S. and Mexico.” Los Angeles Times. March 10. Retrieved April 11, 2012: http://articles.latimes.com/1992-03-10/news/mn-3541 1 grupo-beta

1992b. "Border Meeting Closes in Amity: Cooperation: U.S. and Mexican governors praise the Free Trade Agreement and vow to work together to fight growing ecological hazards along the border." Los Angeles Times. April 4. Retrieved April 11, 2012 (http://articles.latimes.com/199204-04/local/me-94_1_free-trade-agreement)

1993a. "Border Watch: Just too good?" Los Angeles Times. 6 Sept. 1993. Retrieved April 11, 2012. (http://articles.latimes.com/1993-09-16/local/me-35588_1_grupo-beta) 
Roy, Marc André and Peter Kieran. 2006. "Rail Privatisation Rolls Across the Continent.” IRJ (March 2006): 38-41.

Rumford, Chris. 2009. Citizens and borderwork in contemporary Europe. Routledge.

Sacristián Roy, Emilio. 2002. "Resultados de la restructuración ferroviaria mexicana.” Pp. 107-109 in Memorias del V Encuentro Nacional de Investigadores del Ferrocarril. México: SCT, Conaculta and Museo Nacional de los Ferrocarriles Mexicanos.

Said, Edward. 1993. Culture and Imperialism. London: Vintage.

Salvatore, Ricardo D. 2006. “Imperial Mechanics: South America's Hemispheric Integration in the Machine Age.” American Quarterly 58 (3): 662-691.

Sánchez Martínez, Jesús. 1996. “Auge el Tráfico de Indocumentados en la Frontera Sur.” El Orbe Año XIX, No. 5419. 18 de enero. Front page.

Sassen, Saskia. 1988. The Mobility of Labour and Capital: A Study in International Investment and Labor Flow. New York: Cambridge University Press.

-----. 1999. Guests and Aliens. New York: New Press.

-----. 2000. "Regulating Immigration in a Global Age: A New Policy Landscape." The Annals of the American Academy of Political and Social Science 570: 65-77

-----. 2015. “Bordering Capabilities versus Borders: Implications for National Borders.” Pp. 23-52 in Borderities and the Politics of Contemporary Mobile Borders. United Kingdom: Palgrave Macmillan.

Schivelbusch, Wolfgang. [1977] 2014. The Railway Journey. The Industrialization of Time and Space in the Nineteenth Century. University of California Press. 
Schwenken, H., \& Ruß-Sattar, S. 2014. "New Border and Citizenship Politics: An Introduction.” Pp. 113 in New Border and Citizenship Politics. U.K.: Palgrave Macmillan.

SCOP. 1976. Obras Públicas en México. Documentos para su Historia 2. Ferrocarriles de México.

Reseña histórica- Reglamentos (Siglo XIX). México: Edición de la Secretaría de Obras Públicas (AGN).

1933. Estadística de Ferrocarriles y Tranvías de Concesión Federal Correspondiente al año

1931. Mexico, D.F. Secretaría de Comunicaciones y Obras Públicas. Depto. de

Communicaciones Terrestres (Courtesy of CEDIF Archives).

Scott, James C. 2009. The Art of Not Being Governed. An Anarchist History of Upland Southeast Asia. New Haven and London: Yale University Press.

Secretaría de Comunicaciones y Obras Públicas (SCOP)- Estadística de Ferrocarriles y Tranvías de Concesión Federal. Correspondiente al año de 1931. Depto. de Comunicaciones Terrestres. 1933. México, D.F: Cia. Impresora Papelera, S.A. (Courtesy of CEDIF archive)

SCT. 1997. Anuario estadístico ferroviario. 1997. Dirección General de Tarifas, Transporte

Ferroviario y multimodal. México, DF: Secretaría de Comunicaciones y Transportes (SCT).

Retrieved June 19, 2015

(http://www.sct.gob.mx/fileadmin/DireccionesGrales/DGTFM/Anuarios_DGTFM/Anuarios_pdf /Anuario 1997.pdf)

SCT. 1998. Anuario estadístico ferroviario. 1997. Dirección General de Tarifas, Transporte Ferroviario y multimodal. México, DF: Secretaría de Comunicaciones y Transportes (SCT). Retrieved June 29, 2015. 
SCT. 2000. Anuario estadístico ferroviario. 2000. Dirección General de Tarifas, Transporte

Ferroviario y multimodal. México, DF: Secretaría de Comunicaciones y Transportes (SCT).

Retrieved June 29, 2015.

SCT. 2001. Primer Informe de Labores 2000-2001. Retrieved July 2015

(http://www.sct.gob.mx/fileadmin/_migrated/content_uploads/SCT-inflab-2000-2001.pdf)

SCT. 2002. Segundo Informe de Labores 2001-2002. Retrieved July 2015

(http://www.sct.gob.mx/fileadmin/_migrated/content_uploads/SCT-inflab-2001-2002.pdf)

SCT. 2003. Anuario estadístico ferroviario 2003. Dirección General de Tarifas, Transporte Ferroviario y multimodal. México, DF: Secretaría de Comunicaciones y Transportes (SCT). Retrieved June 19,2015

(http://www.sct.gob.mx/fileadmin/DireccionesGrales/DGTFM/Anuarios_DGTFM/Anuarios_pdf (Anuario_2003.pdf)

SCT. 2003a. Tercer Informe de Labores 2002-2003. Retrieved July 2015

(http://www.sct.gob.mx/fileadmin/_migrated/content_uploads/SCT-inflab-2002-2003.pdf)

SCT. 2004. Cuarto Informe de Labores 2003-2004. Retrieved July 2015

(http://www.sct.gob.mx/fileadmin/_migrated/content_uploads/4toinforme_labores.pdf)

SCT. 2005. Quinto Informe de Labores 2004-2005. Retrieved July 2015

(http://www.sct.gob.mx/fileadmin/_migrated/content_uploads/SCT-Inf-Lab-2005.pdf)

SCT. 2006. Sexto Informe de Labores 2005-2006. September 1, 2006. Retrieved July 2015

(http://www.sct.gob.mx/fileadmin/_migrated/content_uploads/SCT-Inf-Lab-2005-2006.pdf)

SCT. 2013. Anuario estadístico ferroviario 2013. Dirección General de Transporte Ferroviario y 
Multimodal. México, DF: Secretaría de Comunicaciones y Transportes (SCT). Consulted online June 19, 2015. Retrieved

http://www.sct.gob.mx/fileadmin/DireccionesGrales/DGTFM/Anuarios_DGTFM/Anuarios_pdf/ANUARI O-2013ok.pdf

Sheffer, Gabriel. 1993. “Ethnic Diasporas: A Threat to their Hosts?” Pp. 263-285 in International Migration and Security, edited by Myron Weiner. Boulder, Colorado: Westview Press Ltd.

Sibaja Carbott, Arturo. 2000. "El ferrocarril panamericano." Pp. 281-287 in Memorias del IV Encuentro Nacional de Investigadores del Ferrocarril. México: Conaculta and Museo Nacional de los Ferrocarriles Mexicanos.

-----. 2002. “El Tren: la bayunca, el trabajo, la distracción y el amor.” Pp. 83-87 in Memorias del VI Encuentro Nacional de Investigadores del Ferrocarril. México: Conaculta and Museo Nacional de los Ferrocarriles Mexicanos.

Specht, J. 2009. "Between Immigration Control and Human Rights Protection: The Ambiguities of Mexico's Migration Policy-The Case of the Beta Groups for Protection of Migrants." Paper prepared for the International Studies Association Annual Conference 2009, New York.

Star, Susan Leigh. 1999. “The Ethnography of Infrastructure.” American Behavioral Scientist 43(3): $377-391$.

Stephen, Lynn. 2007, Transborder lives: indigenous Oaxacans in Mexico, California, and Oregon. Duke University Press, Durham.

Strategic Survey. 1990. "Mass migration and international security." Strategic Survey, 91 (1): 37-48. 
Suliman, Samid. 2016. "Mobility and the kinetic politics of migration and development." Review of International Studies 42 (4): 702-723.

Swyngedouw 1999

Tazzioli, Martina and William Walters. 2016. "The Sight of Migration: Governmentality, Visibility and Europe's Contested Borders." Global Society 30 (3): 445-464.

Thelle, Mikkel. 2015. "Feeling Motion: Revisiting Mobility History through Affect and Emotion." Mobility in History 6(1): 63-69.

Thompson, Louis. S., Karim-Jacques Budin, and Antonio Estache. 2001. "Private Investment in Railways: Experience from South and North America, Africa and New Zealand.” Paper presented at European Transport Conference. September 2001.

Ticktin, Miriam. 2005. "Policing and humanitarianism in France: immigration and the turn to law as state of exception." interventions 7(3): 346-368.

-----. 2007. "The Offshore Camps of the European Union: At the Border of Humanity.” In Paper presented at the American Anthropological Association Annual Meetings.

Tilly, Charles. 2001. "Historical Sociology.” Pp. 6753-6757 in International Encyclopedia of the Behavioral and Social Sciences (2001). Vol. 10. Amsterdam: Elsevier. 1985. "War making and State Making as Organized Crime." Pp. 169-191 in Bringing the State Back In, edited by P. B. Evans, D. Rueschemeyer and T. Skocpol. Cambridge and New York: Cambridge University Press.

Torpey, John. 2000. The Invention of the Passport. Surveillance, Citizenship and the State. Cambridge, UK: Cambridge University Press. 
Traven, Bruno. 1949. La Carreta. Cia. General de Ediciones, S.A. de C.V.

Tsing, Anna. 2005. Friction: An Ethnography of Global Connection. Princeton University Press.

Tyler, Imogen. 2006. “'Welcome to Britain’ The cultural politics of asylum.” Cultural Studies 9(2): 185-202.

Ultreras, Pedro. 2012. La Bestia. La Tragedia de migrantes centroamericanos en México. Mesa, Arizona: Hispanic Institute of Social Issues.

United Nations Development Programme. 1994. "Chapter 2: The Dimensions of Human Security." United Nations Human Development Report 1994. New dimensions of human security. New York: United Nations. Retrieved when? (http://hdr.undp.org/en/media/hdr_1994_en_chap2.pdf)

UNICEF and INEGI. N.d. Derecho a la identidad. La cobertura del registro de nacimiento en México en 1999 y 2009. Retrieved August 23, 2016 (http://www.unicef.org/mexico/spanish/mx_registrodenacimiento(3).pdf )

Ureste, Manu and Arturo Ángel. 2016. "Con cámaras, brigadas de seguridad privada y drones, así planea México blindar a La Bestia." Animal Político. Retrieved August 30, 2016. (http://www.animalpolitico.com/2016/08/camaras-brigadas-seguridad-drones-asi-planea-mexicoblindar-la-bestia/)

Urry, John. 2007. “'Public' Trains.” Pp. 90-111 in Mobilities. Cambridge and Malden: Polity.

Vanderwood, Paul J. 1981. Disorder and Progress. Bandits, Police and Mexican Development. Lincoln and London: University of Nebraska Press.

Van Houtum, H. 2012. "Remapping borders.” Pp. 405-418 in A,Companion to Border Studies,. 
Van Riemsdijk, Micheline. 2012. “(Re) scaling Governance of Skilled Migration in Europe: Divergence, Harmonisation, and Contestation.” Population, Space and Place 18(3): 344-358.

Vaughan-Williams, Nick 2015. "We are not animals!" Humanitarian border security and zoopolitical spaces in EUrope." Political Geography 45: 1-10.

Villanueva, Jorge. Tapachula a Través del Tiempo. Facebook Page. Retrieved October 2018 (https://www.facebook.com/Por.Jorge.Villanueva/).

Vogt, Wendy. 2013. "Crossing Mexico: Structural Violence and the commodification of undocumented -Central American migrants." American Ethnologist 40 (4): 764-780.

Waever, Ole. 1998. "Securitization and Desecuritization." Pp. 39-69 in On Security, edited by Ronnie D. Lipschutz. New York: Columbia University Press. Retrieved April 12, 2012 (http://library.northsouth.edu/Upload/On\%20Security.pdf)

Walters, William. 2008. "Bordering the sea: shipping industries and the policing of stowaways." Borderlands 7(3): 1-25.

-----. 2010. "Foucault and frontiers: notes on the birth of the humanitarian border." Pp. 138-164 in Governmentality: Current issues and future challenges, Edited by Ulrich Bröckling, Susanne Krasmann and Thomas Lemke. New York: Routledge.

-----. 2012. Governmentality: critical encounters. Routledge.

-----. 2015. "Migration, vehicles, and politics: Three theses on viapolitics." European Journal of Social Theory 18(4): 469-488.

2016. "The flight of the deported: aircraft, deportation, and politics." Geopolitics 21(2): 435-458. 
-----. 2017. "Aviation as deportation infrastructure: airports, planes, and expulsion.” Journal of Ethnic and Migration Studies. 0 (0): 1-22.

Washbrook, Sarah. 2007. "Enganche and Exports in Chiapas, Mexico: A Comparison of Plantation Labour in the Districts of Soconusco and Palenque 1876-1911." Journal of Latin American Studies 39 (4): 797-825.

Weber, Max. [1919] 1946. "Politics as Vocation.” Pp. 77-128 in From Max Weber: Essays in Sociology. Translated and edited by H.H. Gerth and C. W. Mills, New York: Oxford University Press.

Weiner, Myron. 1992/93. "Security, Stability, and International Migration.” International Security 17(3): 91-126.

-----. 1993. International Migration and Security, edited by Myron Weiner. Boulder, Colorado: Westview Press Ltd.

-----. 1995. The Global Migration Crisis: Challenge to States and Human Rights. Harper Collins Publishers.

Wellings, Richard. 2014. “The Privatisation of the UK Railway Industry: An Experiment in Railway Structure.” Economic Affairs 34 (2): 255-266.

Williams, J. M. 2015. “From humanitarian exceptionalism to contingent care: Care and enforcement at the humanitarian border." Political Geography 47: 11-20.

Wohlgemuth, Neusa Hidalgo-Monroy. 2014. "Migration and Indigenous Communities in the Southern States of Oaxaca and Chiapas, Mexico." Perspectives on Global Development and Technology 13 (3): $379-400$. 
Xiang, Biao and Johan Lindquist. 2014. "Migration Infrastructure.” International Migration Review 48(s1): S122-S148.

Zolberg, Aristide, Astri Suhrke, and Sergio Aguayo 1989. Escape from Violence: Conflict and the Refugee Crisis in the Developing World. Oxford University Press.

Zolberg, Aristide. 1989. "The Next Waves: Migration Theory for a Changing World.” The International Migration Review. 23(3): 403-430.

-----. 2001. "Introduction: Beyond the Crisis." Pp. 1-18 in Global migrants, Global Refugees, edited by Aristide R Zolberg and Peter M. Benda. New York and Oxford: Berghahn Books.

-----. 2012. "Why Not the Whole World? Ethical Dilemmas of Immigration Policy." American Behavioral Scientist 56(9): 1204- 1222.

\section{Film Sources}

Berger, Greg 'Gringoyo'. 2015. Danger: Journalists Crossing. Narco News TV. Retrieved July 31, 2018 (https://www.youtube.com/watch?v=FrA5PthXufk).

Cammisa, Rebecca. 2009. Which Way Home. United States: Mr. Mudd.

Dirdamal, Tin. 2005. De Nadie. México: Tranvia Producciones.

Fukunaga, Cary Joji. 2009. Sin Nombre. Mexico and United States: Canana Films.

Silver, Marc and Gael Garcia Bernal. 2014. Who is Dayani Cristal? UK and México: Canana Films.

Quemada-Díaz, Diego. 2013. Jaula de Oro. Mexico: CONACULTA 
Rocker, Stefan. 2005. El Tren de la Muerte. Un Reportaje por Stefan Rocker. Televisión Alemana SWR y de Phoenix. Retrieved online October 10, 2018 (https://www.dailymotion.com/video/x2ag53z).

Ultreras, Pedro. 2010. La Bestia. TV Lounge Studios.

Archival Sources

AGN

Archival General de la Nación. Adolfo Ruiz Cortines Archive/ 106141/ Caja 0658; Folders 512.52$513 / 23$.

Archival General de la Nación. Adolfo Ruiz Cortines Archive / 106611/ Caja 1124; Folders 609/11$609 / 62$ 


\begin{tabular}{|l|l|}
\hline Date & \multicolumn{1}{|c|}{ Event } \\
\hline 1877 & Porfirio Diaz becomes President \\
\hline 1890 & $\begin{array}{l}\text { Inauguration of the first railway in southern } \\
\text { Mexico between Puerto Arista and Tonalá }\end{array}$ \\
\hline 1903 & Construction begins on the Panamericano \\
\hline 1904 & $\begin{array}{l}\text { First section of the Panamericano opens } \\
\text { between San Geronimo (Ixtepec) and Tonalá }\end{array}$ \\
\hline 1906 & $\begin{array}{l}\text { Second section of the Panamericano opens } \\
\text { between Tonalá and San Antonio (Chiapas) }\end{array}$ \\
\hline 1950 & $\begin{array}{l}\text { Inauguration of the Panamericano between } \\
\text { San Geronimo (Ixtepec) and Tapachula }\end{array}$ \\
\hline 1955 & $\begin{array}{l}\text { Inauguration of the Pan-American Highway, } \\
\text { which brings motorists and competition to the } \\
\text { Panamericano }\end{array}$ \\
\hline 2005 & $\begin{array}{l}\text { Inaugural Journey of the passenger service } \\
\text { known as El Centroamericano }\end{array}$ \\
\hline $\begin{array}{l}\text { SCT grants the concession for railway } \\
\text { operations along the Panamericano to the } \\
\text { Chiapas-Mayab Railway Company }\end{array}$ \\
\hline $\begin{array}{l}\text { Hurricane Stan destroys bridges and tracks } \\
\text { south of Arriaga; cargo services continue } \\
\text { north of Arriaga; passenger services are } \\
\text { discontinued for the Panamericano }\end{array}$ \\
\hline $\begin{array}{l}\text { Cargo services resume south of Arriaga } \\
\text { following the reconstruction and re-routing of } \\
\text { the Panamericano }\end{array}$ \\
\hline 199
\end{tabular}


Appendix B: Map of Settlements and Stations along the Panamericano

Source: Ortega Nuñez, Alfonso, Jose María López Escamilla, Alfredo Suárez Rabago and Luis Gómez Zepeda. 1977. División del Sureste. Horario No. 6. May 25. N.p- FNM. Mexico: CEDIF Archives. 


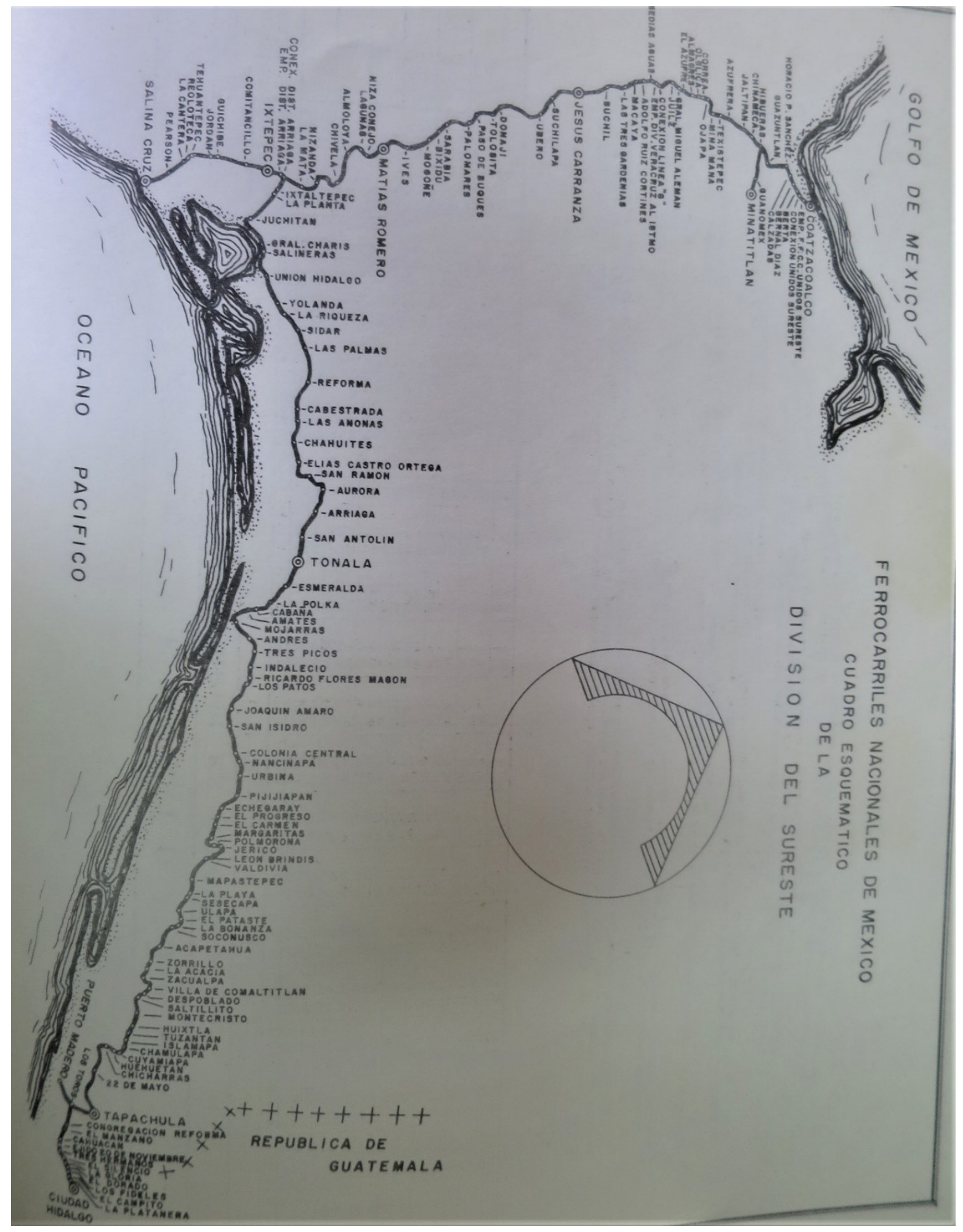


Appendix C: Map of Railways in Southern Mexico (1950)

Source: Secretaría de Comunicaciones y Obras Públicas (SCOP). Dirección General de

Construcción de Ferrocarriles. 1950. Ferrocarril del Sureste. México, D.F. Mexico: CEDIF

Archives.

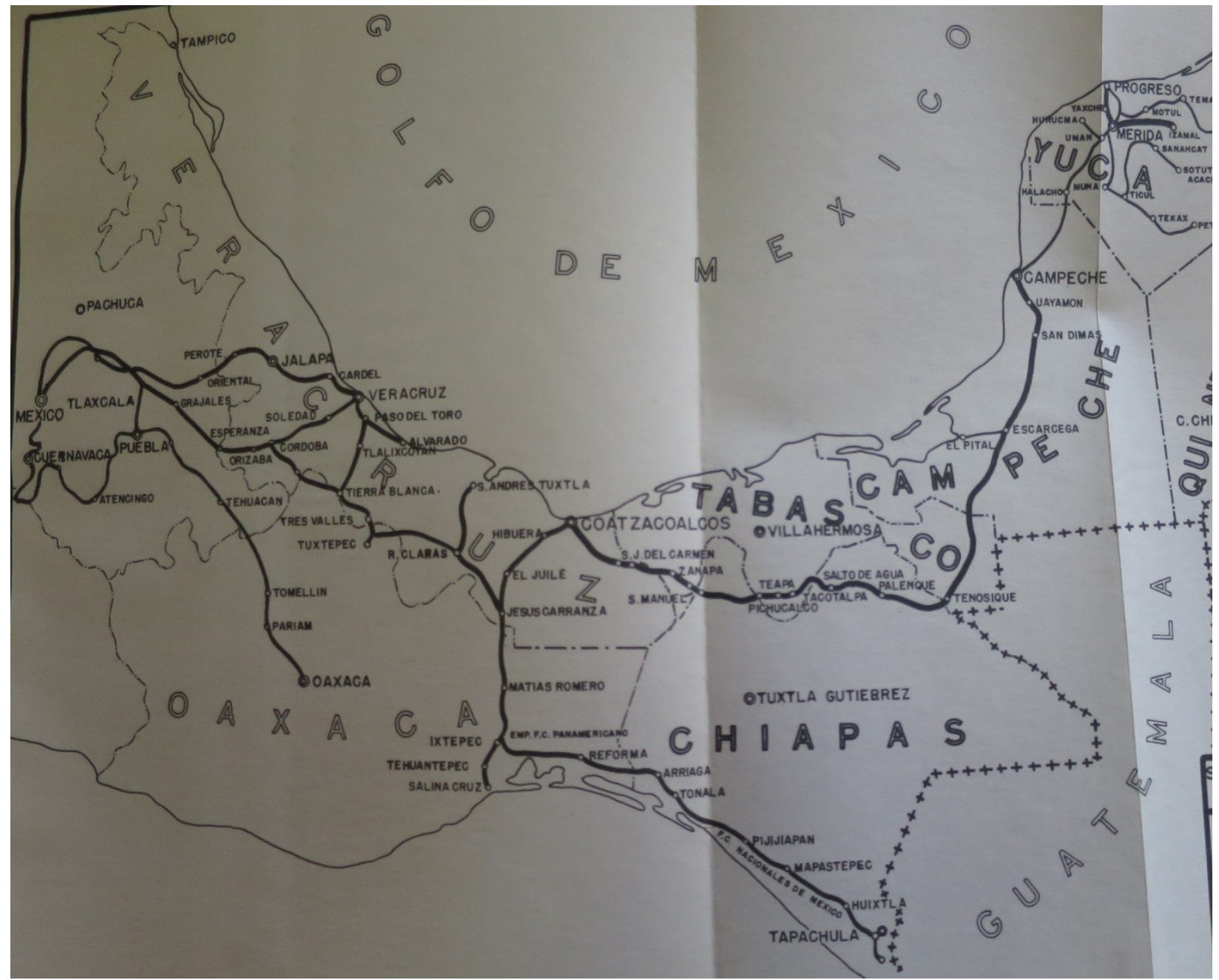

